
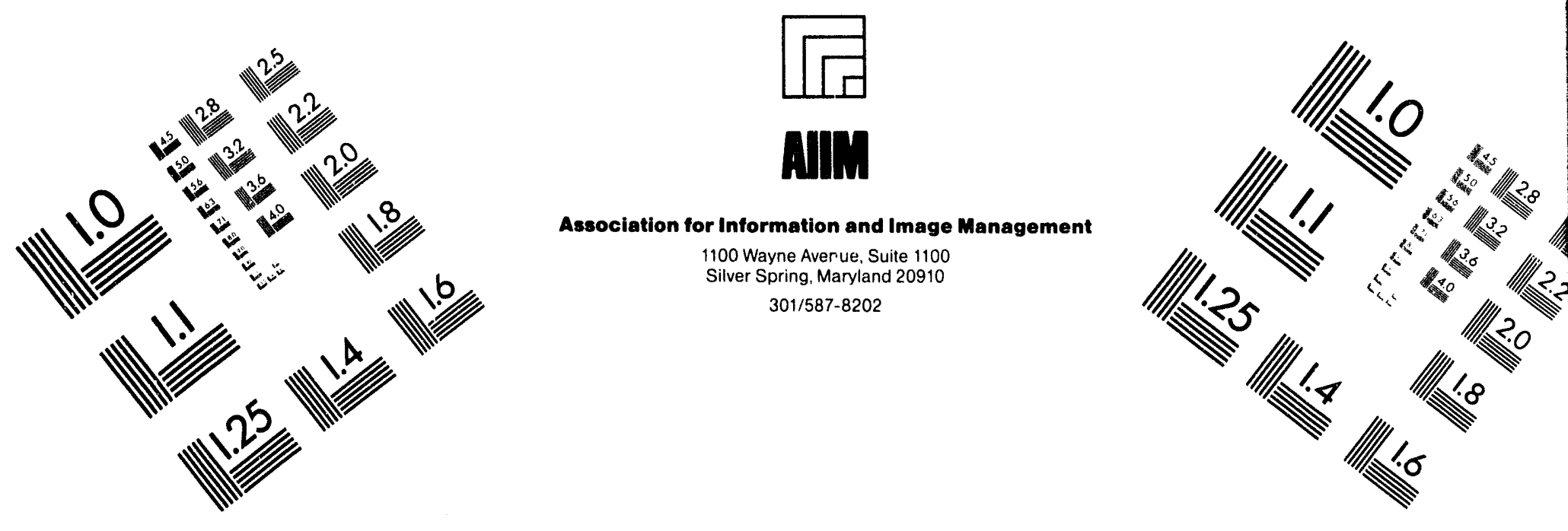

\title{
Centimeter
}

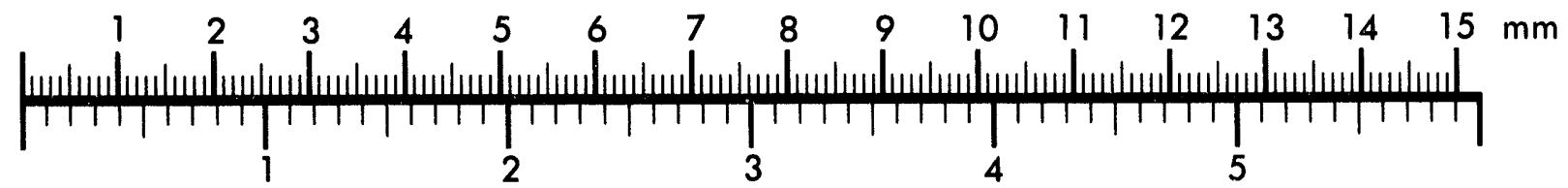
Inches
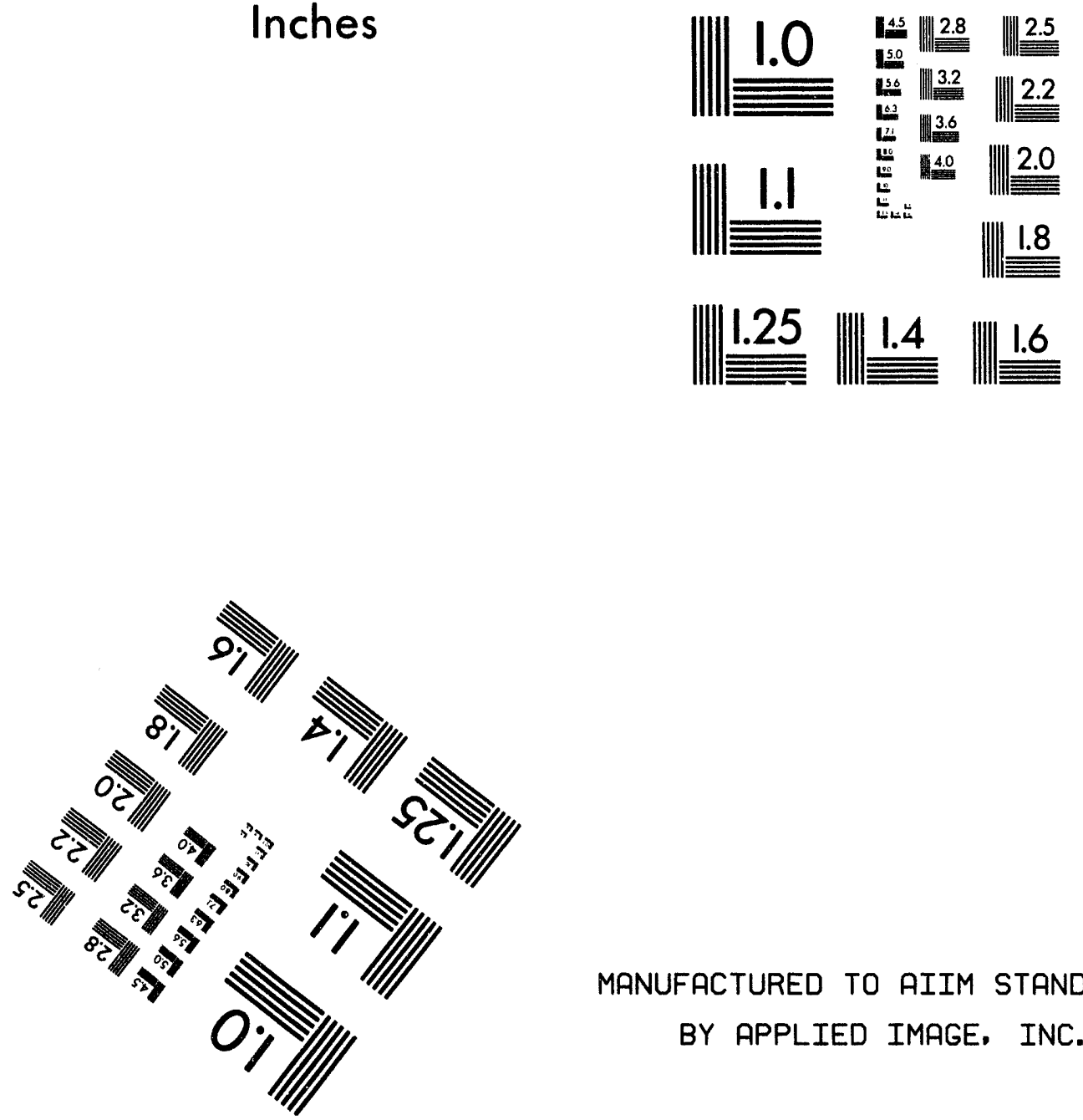

MANUFACTURED TO AIIM STANDARDS BY APPLIED IMAGE. INC.

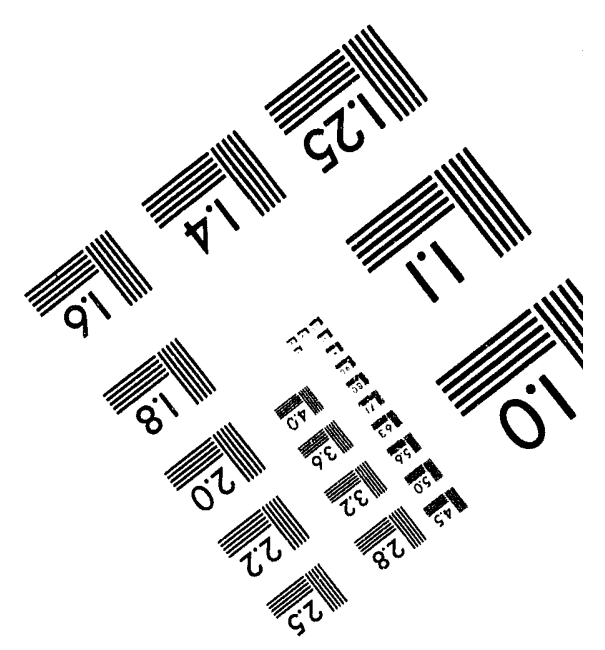



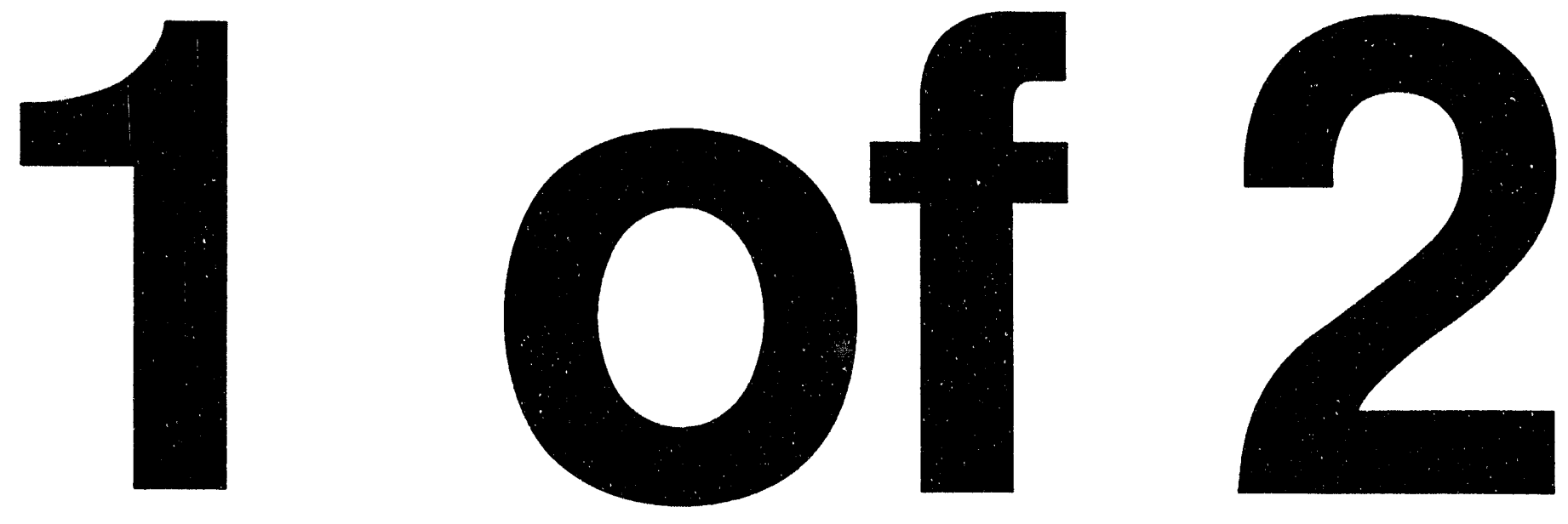


\section{Data Summary Report on Short-Term Turbidity Monitoring of Pipeline River Crossings in the Moyie River, Boundary County, Idaho: PGT-PG\&E Pipeline Expansion Project}

by M.J. Govidy, M.P. Smits, P.L. Wilkey, and S.F. Miller

Reclamation Engineering and Geosciences Section,

Energy Systems Division,

Argonne National Laboratory, 9700 South Cass Avenue, Argonne, Illinois 60439

March 1994

Work sponsored by Bechtel Corporation 


\section{Contents}

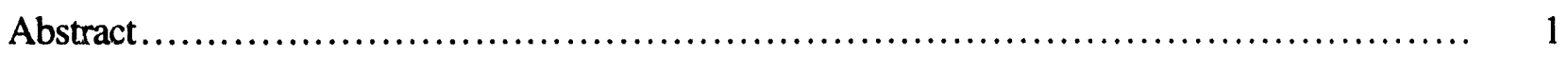

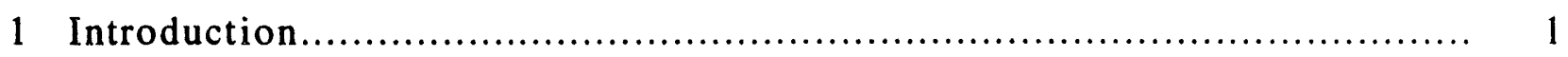

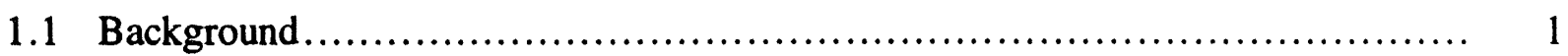

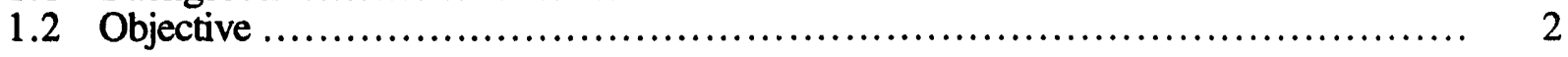

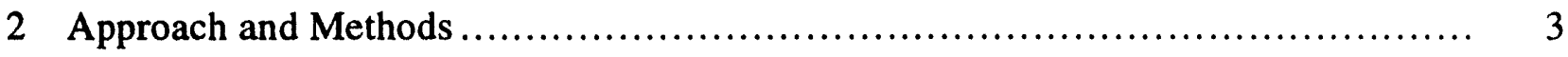

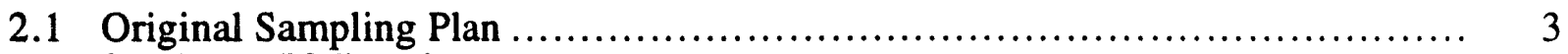

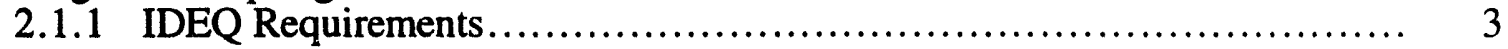

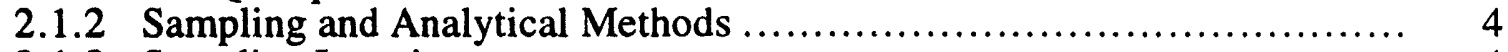

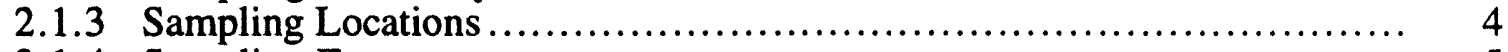

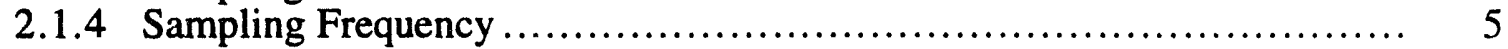

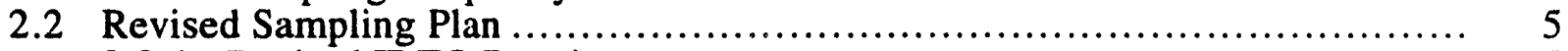

2.2.1 Revised IDEQ Requirements....................................... 5

2.2.2 Modifications to the Sampling Plan........................................ 7

2.2.3 Best Management Practice Structures ................................... 7

2.2.4 Flow-Weighted Averaging .......................................... 8

3 Results and Observations........................................................ 9

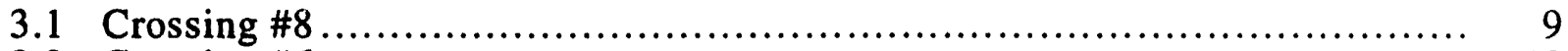

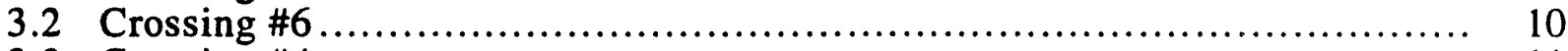

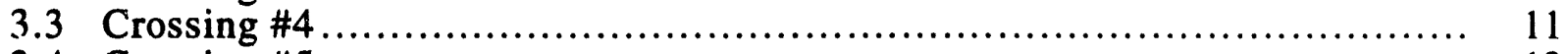

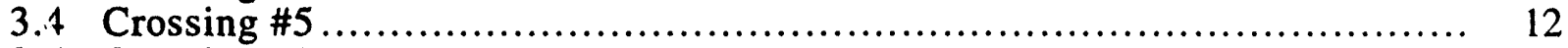

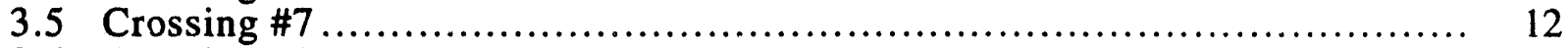

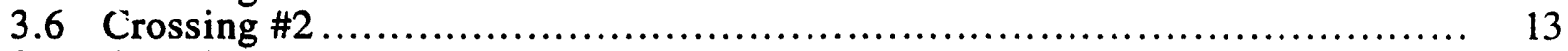

3.7 Crossing \#1 ................................................................................ 14

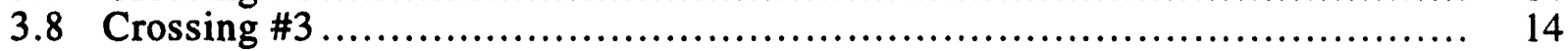

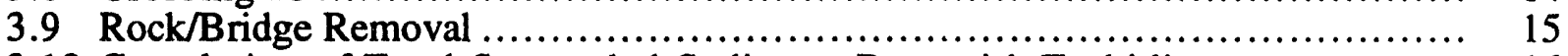

3.10 Correlation of Total-Suspended-Sediment Data with Turbidity...................... 16

4 Conclusions and Recommendations ............................................ 19

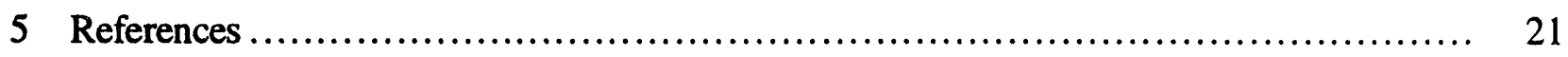

Appendix A: IDEQ Monitoring Requirements .................................. 23

Appendix B: Figures............................................................. 39

Appendix C: Turbidity Data.................................................... 65

Appendix D: Dissolved Oxygen and Temperature Measurements........................ 113 


\section{Tables}

$1 \quad$ Range of TSS Values Calculated Using the Least-Squares

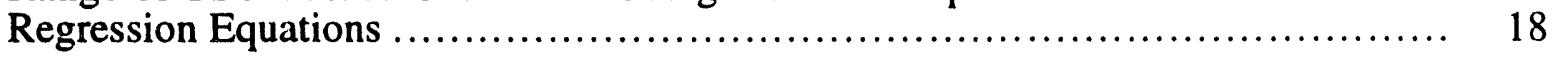

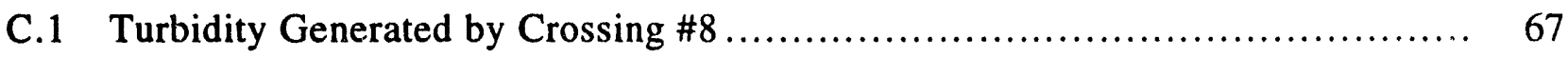

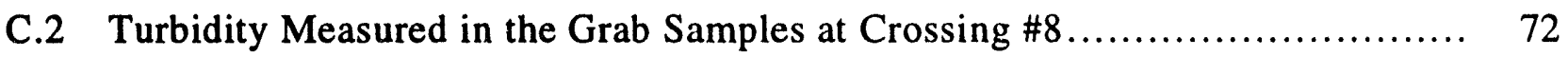

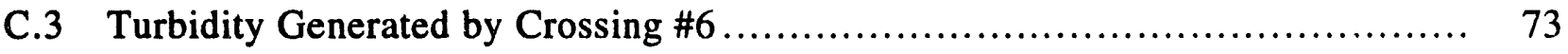

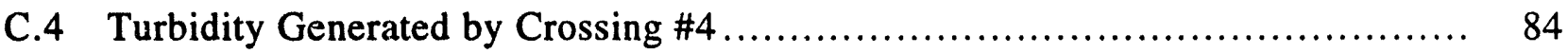

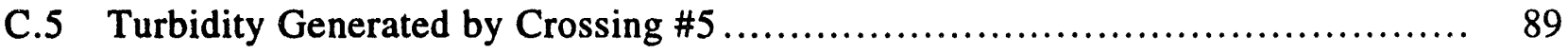

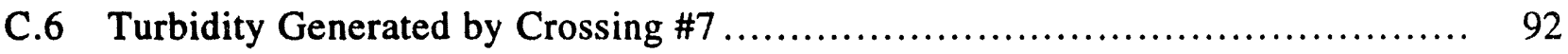

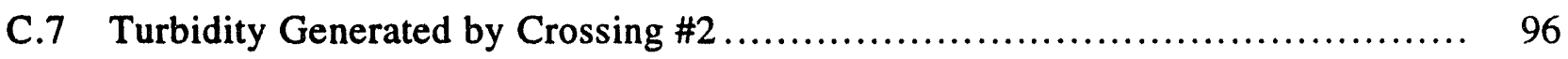

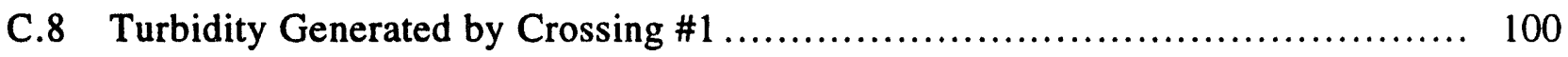

C.9 Turbidity Generated by Crossing \#3 ...................................... 104

D.1 Dissolved Oxygen and Temperature Measurements.......................... 115

\section{Figures}

B.1 Schematic Diagram of Sampling Locations....................................... 41

B.2 Schematic Diagram Indicating Revised Sampler Locations.................... 41

B.3 Crossing \#8: Net Turbidity versus Time as Measured $600 \mathrm{ft}$ Downstream...... 42

B.4 Crossing \#8: Running Average of Net Turbidity versus Time as Measured $600 \mathrm{ft}$ Downstream............................................................ 42

B.5 Crossing \#6: Net Turbidity versus Time as Measured $600 \mathrm{ft}$ Downstream....... 43

B.6 Turbidity Generated by Crossing \#6 as Measured Downstream at the Crossing \#8 Sampling Location.

B.7 Crossing \#6: Running Average of Net Turbidity versus Time as Measured $600 \mathrm{ft}$ Downstream.

B.8 Turbidity Generated by Crossing \#4 as Measured Downstream at Sampling Locations at Crossings \#6 and \#8

B.9 Crossing \#4: Net Turbidity versus Time as Measured by Three Samplers $600 \mathrm{ft}$ Downstream. 


\section{Figures (Cont.)}

B.10 Crossing \#4: Flow-Weighted Average of Net Turbidity Measured by Three Samplers $600 \mathrm{ft}$ Downstream versus Time

B.11 Crossing \#4: Running Average of Flow-Weighted Net Turbidity as Measured $600 \mathrm{ft}$ Downstream versus Time

B.12 Crossing \#4: Dissolved Oxygen Measured Upstream and $600 \mathrm{ft}$ Downstream versus Time.

B.13 Crossing \#5: Net Turbidity versus Time as Measured by Three Samplers $600 \mathrm{ft}$ Downstream

B.14 Crossing \#5: Flow-Weighted Average of Net Turbidity Measured by Three Samplers $600 \mathrm{ft}$ Downstream versus Time

B.15 Crossing \#5: Running Average of Flow-Weighted Net Turbidity as Measured $600 \mathrm{ft}$ Downstream versus Time...

B.16 Turbidity Generated by Crossing \#5 as Measured Downstream at Sampling Locations at Crossings \#6 and \#8

B.17 Crossing \#5: Dissolved Oxygen Measured Upstream and $600 \mathrm{ft}$ Downstream versus Time.

B.18 Crossing \#5: Temperature Measured Upstream and $600 \mathrm{ft}$ Downstream versus Time.

B.19 Turbidity Generated by Crossing \#7 as Measured Downstream at the Crossing \#8 Sampling Location

B.20 Crossing \#7: Net Turbidity versus Time as Measured by Three Samplers $600 \mathrm{ft}$ Downstream

B.21 Crossing \#7: Flow-Weighted Average of Net Turbidity Measured by Three Samplers $600 \mathrm{ft}$ Downstream versus Time

B.22 Crossing \#7: Running Average of Flow-Weighted Net Turbidity as Measured $600 \mathrm{ft}$ Downstream versus Time.

B.23 Crossing \#7: Dissolved Oxygen Measured Upstream and $600 \mathrm{ft}$ Downstream versus Time.

B.24 Crossing \#7: Temperature Measured Upstream and $600 \mathrm{ft}$ Downstream versus Time

B.25 Turbidity Generated by Crossing \#2 as Measured Downstream at the Sampling Locations at Crossings \#4, \#5, \#6, \#7, and \#8

B.26 Crossing \#2: Net Turbidity versus Time as Measured by Three Samplers $600 \mathrm{ft}$ Downstream 


\section{Figures (Cont.)}

B.27 Crossing \#2: Flow-Weighted Average of Net Turbidity Measured by Three Samplers $600 \mathrm{ft}$ Downstream versus Time

B.28 Crossing \#2: Running Average of Flow-Weighted Net Turbidity as Measured $600 \mathrm{ft}$ Downstream versus Time...

B.29 Crossing \#2: Dissolved Oxygen Measured Upstream and $600 \mathrm{ft}$ Downstream versus Time.

B.30 Crossing \#2: Temperature Measured Upstream and $600 \mathrm{ft}$ Downstream versus Time.

B.31 Turbidity Generated by Crossing \#1 as Measured Downstream at Sampling Locations at Crossings \#2, \#4, \#5, \#6, \#7, and \#8

B.32 Crossing \#1: Net Turbidity versus Time as Measured by Three Samplers 600 tt Downstream.

B.33 Crossing \#1: Flow-Weighted Average of Net Turbidity Measured by Three Samplers $600 \mathrm{ft}$ Downstream versus Time

B.34 Crossing \#1: Running Average of Flow-Weighted Net Turbidity as Measured $600 \mathrm{ft}$ Downstream versus Time

B.35 Crossing \#1: Dissolved Oxygen Measured Upstream and $600 \mathrm{ft}$ Downstream versus Time

B.36 Crossing \#1: Temperature Measured Upstream and $600 \mathrm{ft}$ Downstream versus Time

B.37 Crossing \#3: Net Turbidity versus Time as Measured by Three Samplers $600 \mathrm{ft}$ Downstream.

B.38 Turbidity Generated by Crossing \#3 as Measured Downstream at Sampling Locations at Crossings \#3, \#4, \#5, \#6, \#7, and \#8

B.39 Crossing \#3: Flow-Weighted Average of Net Turbidity Measured by Three Samplers $600 \mathrm{ft}$ Downstream versus Time

B.40 Crossing \#3: Running Average of Flow-Weighted Net Turbidity as Measured $600 \mathrm{ft}$ Downstream versus Time.

B.41 Crossing \#3: Dissolved Oxygen Measured Upstream and $600 \mathrm{ft}$ Downstream versus Time.

B.42 Crossing \#3: Temperature Measured Upstream and $600 \mathrm{ft}$ Downstream versus Time

B.43 Total Suspended Solids versus Turbidity for Crossing \#1 ...................... 62

B.44 Total Suspended Solids versus Turbidity for Crossing \#3.................... 62 
Figures (Cont.)

B.45 Total Suspended Solids versus Turbidity for Crossing \#5 ................... 63

B.46 Total Suspended Solids versus Turbidity for Crossings \# 1, \#3, and \#5......... 63 


\title{
Data Summary Report on Short-Term Turbidity Monitoring of Pipeline River Crossings in the Moyie River, Boundary County, Idaho: PGT-PG\&E Pipeline Expansion Project
}

by

M.J. Gowdy, M.P. Smits, P.L. Wilkey, and S.F. Miller

\begin{abstract}
A water-quality monitoring program was implemented for Bechtel Corporation to measure the short-term increases in turbidity in the Moyie River caused by construction activities of the Pacific Gas Transmission-Pacific Gas \& Electric Pipeline Expansion Project. Construction of the buried, 42-in.-diameter, steel pipeline, during the summer of 1992, involved eight wet crossings of the Moyie River along the 13-mi section of pipeline immediately south of the CanadianUnited States border in Boundary County, Idaho. This report summarizes the sampling and analysis protocol used and gives the results and observations for each of the eight crossings. The data obtained from this monitoring program, in addition to satisfying regulatory requirements for the Pipeline Expansion Project, will contribute to an ongoing long-term study of the Moyie River crossings being performed for the Gas Research Institute by Argonne National Laboratory. The purpose of this document is strictly limited to reporting the results of the monitoring program. Interpretation of the data is not within the scope of this report.
\end{abstract}

\section{Introduction}

\subsection{Background}

Pacific Gas Transmission (PGT) and Pacific Gas \& Electric (PG\&E) are expanding the existing natural gas pipeline system that runs from the Canadian-United States border near Eastport, Idaho, to the Central Valley of California. The construction manager is Bechtel Corporation. The Pipeline Expansion Project (referred to as the Project) involved installing a new, buried, 36-in.- or 42-in.-diameter steel pipeline alongside an existing 36-in.-diameter, buried pipeline, generally in the same right of way. This study focused on a 13-mi segment of pipeline construction that crossed the Moyie River eight times near the Canadian border in Boundary County, Idaho. In general, the construction of the pipeline river crossings involved excavating a 12-ft-deep trench across the flowing river, floating a section of pipe across the trench, lowering the pipe section into the trench, and backfilling. As part of the U.S. Army Corps of Engineers 
Section 404 permit issued to PGT-PG\&E on March 4, 1992, for crossing the Moyie River, the Idaho Division of Environmental Quality (IDEQ) established water-quality monitoring requirements and exceedance standards for increases in turbidity caused by all such "instream" construction activities. These requirements were expressed in IDEQ's Section 401 Water Quality Certification, issued by IDEQ in their letter of January 14, 1992. Argonne National Laboratory (ANL) was contracted by Bechtel to carry out this monitoring program and to document the results.

The ANL monitoring program for Bechtel, in addition to satisfying the Corps and IDEQ monitoring requirements, provided supplementary data to an ongoing Gas Research Institute (GRI) study also being performed by ANL. As a part of the Project, PGT-PG\&E installed permanent rock flow-control structures downstream of each pipeline crossing, to diversify channel water velocities over the width of the stream, and at additional locations in the river segment, to create low-energy zones near the shore (PGT and PG\&E 1992). These flow-control structures were designed to

- Enhance and create new fish habitat in the Moyie River to reduce and mitigate the potential effects of pipeline construction at the stream crossing;

- Provide erosion control by controlling flow velocities and minimizing long-term bank scour;

- Maintain cover over the pipeline trench; and

- Catch sediment and decrease flow velocities during instream construction activities.

The GRI study is analyzing the effectiveness of these flow-control structures with regard to the objectives. The data collected for the Bechtel monitoring program will augment the data collected for the GRI study and provide a more detailed characterization of the actual short-term increases in turbidity caused by construction activities.

\subsection{Objective}

The objective of ANL's wcrk was to implement the turbidity-monitoring program required by the IDEQ Water Quality Certification and to document the results. This report summarizes specifically the results of the work performed by ANL for Bechtel to comply with IDEQ monitoring requirements. The information collected by ANL for the Bechtel monitoring program also provided the GRI study with supplementary data characterizing the turbidity caused by construction activities. 


\section{Approach and Methods}

The crossings were numbered sequentially downstream between crossings \#1 and \#8. Pipeline river crossing \# 1 was the northernmost crossing, located near Eastport, Idaho, and crossing \#8 was 16 river miles downstream from crossing \#1, near the confluence of Meadow Creek and Moyie River. The eight crossings were constructed in the following order: \#8, \#6, \#4, $\# 5, \# 7, \# 2$, \#1, and \#3. The first two crossings (\#8 and \#6) were monitored according to conditions outlined by IDEQ in the original Water Quality Certification in January 1992. However, after very high turbidity levels and uneven mixing over the stream cross section were observed, a revised monitoring scheme was adopted in August 1992 for the remaining crossings.

\subsection{Original Sampling Plan}

\subsubsection{IDEQ Requirements}

The short-term water-quality-monitoring requirements of the permit were outlined by IDEQ in Section 1a of their letter dated January 14, 1992. A copy of this letter is reprinted in Appendix A for reference. The items listed below applied directly to the monitoring program being implemented by ANL:

- Turbidity will be the water-quality parameter measured.

- Measurements will be taken immediately upstream and $600 \mathrm{ft}$ downstream of the trenching activity. The upstream location will be far enough upstream to be unaffected by construction and will allow background turbidity to be measured. A best professional judgment of $600 \mathrm{ft}$ downstream was determined by IDEQ as the distance required for dissipation on the basis of the permit for what the IDEQ considered to be an analogous river crossing in California (the upper Sacramento River crossing permit issued by the Army Corps of Engineers, Sacramento).

- The downstream turbidity is not to exceed background turbidity by more than 50 nephelometric turbidity units (NTU) instantaneously or 25 NTU averaged over a 10-day period.

- Sampling frequency will be high enough to detect an error of 0.5 NTU (10\%) at the dow nstream station with a $95 \%$ confidence level.

All other monitoring tasks described in the letter (e.g., long-term monitoring for embeddedness) were outside the scope of the ANL contract with Bechtel and are being reported to the IDEQ directly by Bechtel. 


\subsubsection{Sampling and Analytical Methods}

Battery-powered ISCO model 2900 and model 3700 portable samplers were used to pump approximately $500 \mathrm{~mL}$ of sample out of the river at regular time intervals. The ISCO samplers internally stored 24 samples that were retrieved every 12-24 hours, depending on the sampling frequency, and brought back to the field laboratory for analysis.

Each sample was analyzed for turbidity according to the protocol outlined in Part 2130 of Standard Methods for the Analysis of Water and Wastewater (Clesceri, Greenberg, and Trussell 1989). The instrument used in the analysis was an Orbeco-Hellige Digital Turbidimeter model 96510. This instrument is a side-scatter-type nephelometer that measures light scattered by suspended particles at right angles to the incident light source. The instrument converts the measured light scatter to a turbidity reading given in nephelometric turbidity units (NTU). Each time the instrument was turned on and warmed up, or after every 100 samples, it was calibrated with a stock turbidity suspension of hydrazine sulfate (formazine). This instrument had a range from 0 to 1,000 NTU in three range spans: $0-9.99 \mathrm{NTU}, 0-99.9 \mathrm{NTU}$, and 0-999 NTU. The instrument sensitivity was 0.01 NTU, or \pm 1 digit; instrument linearity was $\pm 0.75 \%$ of full scale; irstrument repeatability was $\pm 0.2 \%$, or \pm 1 digit.

Each sample retrieved from the ISCO samplers was agitated to resuspend any particles that settled out during storage, and approximately $20 \mathrm{~mL}$ of each sample was transferred to its own clean, clear, glass sample tube. The samples were screened visually as a first approximation of turbidity. For samples with turbidity less than $40 \mathrm{NTU}$, the sample tube was agitated again, wiped clean, and, after air bubbles were allowed to dissipate, analyzed with the nephelometer. Even though the nephelometer had a range of up to 1,000 NTU, Standard Methods suggests a dilution technique for samples with turbidity higher than 40 NTU. These high-turbidity samples were diluted with turbidity-free water (commercial demineralized water) until the turbidity fell to between 20 and 40 NTU. Turbidity of the original sample was then calculated from the turbidity of the diluted sample and the dilution factor. Measurements were taken on the 0 to 99.9 NTU range setting of the nephelometer and reported to the nearest 1 NTU.

\subsubsection{Sampling Locations}

On the basis of the best professional judgment of IDEQ, the downstream samplers were located $600 \mathrm{ft}$ from the centerline of each trench. Simultaneously with taking the downstream samples, background samples were taken at locations far enough upstream (usually about 100-200 ft) to be unaffected by construction activities. The net downstream turbidity was calculated by subtracting the measured background (upstream) turbidity from the simultaneous downstream turbidity measurement. In this way, the effects of naturally occurring turbidity or any upstream activities were removed. The net turbidity was the turbidity resulting from the activities at that particular crossing only. 
At each sampling location, the inlet of the sampler hose was positioned in the main channel or thalweg. Where the flow allowed safe wading into the river, velocity and depth measurements were taken to help locate the thalweg. In cases where the flow was too fast and the channel was too deep for measurement, professional judgment was used to locate the thalweg. The inlet of the sampler was vertically positioned at a depth below the river surface that was $60 \%$ of the total depth at that sampling location. In all cases, the location of the thalweg and placement of the sampler inlet were subjective determinations. Figure B.1 in Appendix B is a schematic diagram showing the locations of the water samplers.

\subsubsection{Sampling Frequency}

The specifications from the IDEQ special conditions required that measurements be taken frequently enough to detect an error of $0.5 \mathrm{NTU}$ with a $95 \%$ confidence level at the downstream monitoring station of each crossing. ANL applied this requirement to the measurement and computation of the 10-day average turbidity. It was impractical, however, to apply this confidence interval to the instantaneous measurements, as approximately 90 simultaneous measurements would have been required. Practically, the accuracy of the instantaneous measurements is considered to be equal to the precision of the analytical methods used (as summarized in Section 2.1.2).

Acknowledging tikc fast that turbidity would be highest and most variable during excavation, sampling downstream was conducted at shorter time intervals during periods of excavation than during periods when downstream turbidity was at background levels. Samples were drawn every $30 \mathrm{~min}$ for 24 hours per day while excavation and backfilling were in progress. Beginning 24 hours after instream construction activities were completed, and after downstream turbidity levels had returned to background levels, samples were drawn once every $60 \mathrm{~min}$, 24 hours per day, for the remainder of the 10-day period or until the running average dropped below the 25-NTU requirement. For each of the crossings, the running average of turbidity was plotted versus time to track how quickly the running average approached the 10-day level. Also, the $95 \%$ confidence interval of the running average was calculated and plotted on the same graphs. The plots for all river crossings appear in Appendix B.

\subsection{Revised Sampling Plan}

\subsubsection{Revised IDEQ Requirements}

The turbidity plumes that were generated by construction of the first two crossings (crossings \#8 and \#6) did not behave as anticipated by IDEQ, and revisions to the sampling protocol were needed to better characterize the sediment plumes. The following observations from crossings \#8 and \#6 led the Corps and IDEQ to reevaluate the sampling protocol: 
- The plume was more persistent than expected, distinguishable as far as the confluence with the Kootenai River, 9-23 mi downstream from the crossing activities (depending on the crossing location).

- Poor mixing $600 \mathrm{ft}$ downstream preclu led representative sampling of the plume at that location.

- Turbidity levels were much higher than the IDEQ 50-NTU instantaneous standard.

In response to these observations, IDEQ changed the sampling requirements as follows (IDEQ 1992):

- Turbidity will be monitored while any instream activity is taking place at a crossing, not only when the trenching is occurring.

- Turbidity monitoring will continue downstream of each crossing until the Project is complete.

- Three samplers will be located $600 \mathrm{ft}$ downstream (at the thalweg and between the thalweg and the edge of the water on each side of the river).

- Downstream movement of the plume will be documented and reported to IDEQ.

- Water temperature and dissolved-oxygen monitoring will be added to the sampling plan.

A copy of this letter appears in Appendix A for reference. The requirements of the amended 401 certification were incorporated into the Corps permit. Although many other concerns were covered in the IDEQ letter, this report will only discuss those affecting the water-quality monitoring requirements.

In addition to monitoring turbidity during trenching and backfilling, crossings will now be monitored during the other instream activities, specifically during installation and removal of the rock/flume bridges and best management practice structures (BMPs) (except for crossings \#8 and \#6, where work was already completed). Monitoring specific to the installation of the flowcontrol/fishery-enhancement structures near any of the crossings was not included in the scope of this work. In order to assist in capturing bed-load sediment, the flow-control structures were installed before pipeline construction began. 


\subsubsection{Modifications to the Sampling Plan}

In response to the IDEQ revisions, three major changes were made to the ANL sampling plan. First, to better characterize the cross-sectional distribution of the turbidity, three samplers were set up across the river $600 \mathrm{ft}$ downstream: one at the center and the other two at the quarter points, as shown schematically in Figure B.2.

Second, after completion of the excavation and backfilling operations, and after downstream turbidity had returned to the background level, the center sampler at each crossing was left in place to monitor at 60-min intervals until the completion of all instream activity at crossings upstream of that crossing. These additional measurements provided extensive data on the downstream extent and dissipation rates of the turbidity plumes.

Third, temperature and dissolved oxygen in the water were measured upstream and $600 \mathrm{ft}$ downstream during instream activities. The instrument used to measure these parameters was a Horiba model U-7, Water Quality Checker. Dissolved oxygen was measured by means of this instrument using a membrane-type galvanic cell with an accuracy of $\pm 1.0 \mathrm{ppm}$; temperature was measured using a thermistor with an accuracy of $\pm 0.5 \mathrm{C}^{\circ}$. Sampling frequency was conducted in accordance with verbal direction from the IDEQ representatives.

\subsubsection{Best Management Practice Structures}

In response to levels of turbidity in excess of the 50-NTU standard, BMPs were developed by Bechtel and the federal and state agencies and submitted to the Corps for their review and approval before the start of each of the remaining crossings. The approved BMPs provided for the use of inlet covers over the flume pipes to reduce water velocity in the working zone; concrete highway (Jersey) barriers to divert, as much as possible, the flow of water around the active excavation equipment and the instream spoil piles; baffles or curtains to contain sediment released from bank cutting; selective pumping to remove some of the highly turbid water to upland application areas; and nighttime construction to minimize turbidity effects on waterfowl feeding (IDEQ 1992). Documenting the progress of construction activities was not within the scope of the ANL project; therefore, a detailed description of the BMPs is not included in this report. However, on the basis of documentation provided to ANL by Bechtel and of field observations made by ANL personnel, the general characteristics of the BMPs, as they affected downstream turbidity, will be discussed. A brief discussion of the BMPs employed at each crossing is presented in Bechtel's embeddedness monitoring report, submitted under separate cover.

Depending on the location of the rock/flume bridge relative to the trench, the configuration, number, and types of the BMPs applied to each crossing varied; as each crossing was completed, new information was gained. Thus, each set of BMPs was specific to a crossing. At the remaining even-numbered crossings (\#2 and \#4), the rock/flume bridge was immediately downstream of the pipe trench. At the remaining odd-numbered crossings (\#1, \#3, \#5, and \#7), the rock/flume bridge was located immediately upstream of the pipe trench. 
Because a number of variables were unknown at each crossing, the effectiveness of the BMPs in reducing turbidity levels is difficult to determine. In general, the jersey barriers provided adequate containment of the spoil pile during the excavation process. Also, the inlet covers over the flume pipes were effective in reducing the water velocity around the spoil pile and excavation equipment. Each crossing appeared to have different subsurface conditions, ranging from coarser grained, low-plasticity material at crossing \#1 to very fine-grained, clayey material at crossing \#7. Subsurface borings were not taken prior to construction, so it was not possible to characterize the differing subsurface conditions at the crossings. Therefore, any observations on the characteristics of the subsurface soil at a particular crossing are subjective. Also, the amount of material removed from each trench, the duration of instream activity, the river flow rate, and BMP configuration varied from crossing to crossing. These variables made it impossible to quantitatively compare the crossings before and after the application of the BMPs to determine how the BMPs may have lowered the turbidity levels. Any qualitative discussion of how the BMPs affected the downstream turbidity at each crossing is included in the section on that crossing.

\subsubsection{Flow-Weighted Averaging}

ANL developed a flow-weighted method to average the turbidity values. A flow-weighted turbidity was calculated by weighting the turbidity reading at each of the three downstream sampler locations by the amount of flow attributable to that sampler. The amount of flow attributable to a sampler was calculated by dividing the river into three sections and calculating the flow in each section from velocity and depth measurements taken at 5- $\mathrm{ft}$ intervals across the river. These velocity and depth measurements and the flow calculations were performed according to standard U.S. Geological Survey procedures (Buchanan and Somers 1969). For the purpose of checking compliance with the 10-day, 25-NTU standard set by IDEQ, the running average of flow-weighted turbidity was plotted versus time for each of the remaining crossings. These plots, showing the $95 \%$ confidence interval of the running average (as previously described in Section 2.1.4), are included in Appendix B. Turbidity data for all the crossings are listed in Appendix C. Dissolvedoxygen and temperature data for the water are shown in Appendix D. 


\section{Results and Observations}

\subsection{Crossing \#8}

Construction activities started instream at crossing \#8 at 2:00 A.M., July 27, 1992. ISCO automatic samplers were set up $350 \mathrm{ft}$ upstream of the pipeline crossing and $600 \mathrm{ft}$ downstream of the crossing. The velocity of the river at these locations was swift ( $2 \mathrm{ft} / \mathrm{s})$, and running intake hose along the river bottom, from the inlet strainer in the river to the sampler on the bank, was not possible. Ropes were extended over the river at these locations to support the sampler intake hose above the water. Near the inlet location, the hose end dropped down to the strainer, which was secured to a concrete block in the river.

The plot of net turbidity versus time (Figure B.3) shows elevated turbidity corresponding to the excavation and backfilling operations. Turbidity approached background levels within one to two hours after instream construction activity ceased. The first peak associated with the excavation of the pipe trench, at 214 NTU, occurred approximately ive hours after the start of excavation. A second peak, at $155 \mathrm{NTU}$, occurred 32 hours after the start of excavation and was associated with backfilling operations. Between the two peaks was a period of nine hours when downstream turbidity was equal to background levels. This area of the plot corresponded to the period when backfilling operations were halted overnight, before resuming again on the morning of July 28. Figure B.3 shows how quickly the suspended sediment was flushed out of the excavation area once instream activity ceased. The plume of turbidity, however, was persistent as it moved further downstream. Bechtel field workers reported that the plume passed through the reservoir and over the spillway at Moyie Springs, 7.7 river miles downstream of crossing \#8, and continued to the confluence with the Kootenai River, another 1.7 river miles past the spillway. In Figure B.4 the running-time-weighted average turbidity is plotted versus time. This plot shows that compliance with the 10-day, 25-NTU average turbidity requirement was attained on the third day (fourth day for the $95 \%$ confidence interval) after instream activities began. For all crossings, gaps in the turbidity data due to sampler malfunctions were filled with interpolations, as shown in the data tables in Appendix C. Interpolating the data is more accurate than simply applying the last previous turbidity measurement over the period of missed samples, as would happen if timeweighted averages were calculated.

A detailed description of the actual trenching operation is not within the scope of this report; however, one aspect of the operation and its apparent impact on turbidity levels warrants discussion. Spoil from trenching the near-shore portions of each crossing was stockpiled on the banks of the river in predesignated spoil-storage areas. In order to avoid double-handling the material and to minimize the length of time that equipment was working in the river, Bechtel field workers decided to temporarily store spoil from excavating the midstream section of the trench in the river, along the upstream side of the pipe trench at the right bank (Luttrell 1993). (By convention, right and left banks are determined as the observer looks upstream.) The amount of spoil stored this way was approximately one-third of the $1,000 \mathrm{yd}^{3}$ excavated at the crossing (Luttrell 1993). As long as this instream spoil pile was in the river, fine-grained soil material off the pile made a visible contribution to the overall turbidity being generated by the operation. 
Table C.1, located in Appendix C, lists the higher turbidity readings on the right-hand side of the river and indicates the unequal mixing of the water and sediment downstream. These data were measured between excavation and backfill, when little or no instream activity was occurring, yet turbidity levels remained high on the right side of the river.

The accuracy of the turbidity versus time characterization of the plume generated by crossing \#8 activities was decreased by the poor mixing in the river in the area between the crossing activities and the sampler located $600 \mathrm{ft}$ downstream. The flow regime in this section of the river was complex and very turbulent, making it difficult to identify a main thalweg. During most of the instream activity, the turbidity plume was observed to be concentrated along the righthand bank of the river in a secondary thalweg. Because the sampler inlet was located in the approximate center of the river, most of the samples taken during the instream activities at crossing \#8 were not representative of the saximum turbidity in the plume.

\subsection{Crossing \#6}

The background sampler for crossing \#6 was set up approximately $150 \mathrm{ft}$ upstream of the pipe trench in a relatively shallow and slow-moving reach of the river. There was difficulty seting up a monitor downstream at $600 \mathrm{ft}$ as the river at this location was divided into two channels around an island. As an alternative, ANL moved the sampler to a position $650 \mathrm{ft}$ downstream, where the two channels had converged again and a county-road bridge was available for use in hanging the intake hose. The country-road bridge was located $50 \mathrm{ft}$ upstream from and parallel to a railroad bridge. The river was deep, narrow, and fast moving at this sampling location. The main channel, or thalweg, was not in the center of the river, but closer to the right bank.

In spite of adjusting the intake location to account for an off-center thalweg, the sediment plume was again channeled around the sampler intake, preventing representative samples of the highest turbidity from being obtained. Similar to the situation at crossing \#8, the sediment was not mixed evenly across the river by the time it reached $650 \mathrm{ft}$ downstream, and the plume was channeled very strongly through the thalweg. This observation and the similar experience at crossing \#8 caused the permitting agencies, particularly IDEQ, to revise the downstream sampling scheme for the remainder of the crossings.

Similar to observations at crossing \#8, the plot in Figure B.5 of turbidity versus time for crossing \#6 shows two peaks, the first associated with excavation and the second with backfill. The first peak reached a maximum of 743 NTU above background and occurred 4.5 hours after the start of instream activities, at 2:00 A.M. on July 31, 1992. The second (backfill) peak reached a maximum of 225 NTU above background 36 hours after the beginning of instream activities. Within five hours of completing the backfill, peak readings at $650 \mathrm{ft}$ downstream had returned to near background levels. Furthermore, as shown in Figure B.6, these turbidity pulses were observed downstream at crossing \#8. The samplers at crossing \#8 gathered samples with a maximum turbidity of $175 \mathrm{NTU}$ and $166 \mathrm{NTU}$ from the excavation and backfilling operations at crossing \#6. In both cases, the pulses traveled the 4.8 river miles from crossing \#6 to 
crossing \#8 in approximately six hours. In Figure B.7, the running-time-weighted average turbidity is plotted versus time, and this plot shows that compliance with the 10-day, 25-NTU average turbidity requirement was attained three days after instream activities began (five days for the $95 \%$ confidence interval).

Similar to the operation at crossing \#8, a portion of the trench spoil was stored in the river during trenching. Turbidity was observed bleeding off the pile during periods of little or no instream activity; the spoil pile was on the same side of the river as the channelization of the sediment plume, so some sediment losses off the spoil pile may not have been picked up at the sampler. Due to constrictions caused by the instream spoil pile and the flume bridge, the level of the river upstream was observed to rise approximately. 8 in.

\subsection{Crossing \#4}

Crossing \#4 was the first river crossing constructed whilc implementing the revised IDEQ requirements. At $600 \mathrm{ft}$ downstream, the river was deeper and slower than at the two previous crossings. The depth profile of the river was flat and shallow, with the thalweg located at the approximate center of the cross section. The velocity profile showed the highest values at the thalweg. The river was $85 \mathrm{ft}$. across, $1.9 \mathrm{ft}$ deep at the thalweg, with a maximum current velocity of $0.6 \mathrm{ft} / \mathrm{s}$. The three sampler intakes were set up at 20,45 , and $70 \mathrm{ft}$ from the right bank.

Activities at crossing \#4 began at 7:00 P.M. on August 13, 1992. The turbidity associated with excavation lasted about 10 hours, with a peak occurring at 1,060 NTU. The turbidity associated with backfilling also lasted about 10 hours, with a peak turbidity of 660 NTU. As shown in Figure B.8, both of these turbidity pulses were traceable downstream at sampling locations for crossings \#6 and \#8, 4.5 and 9.3 river miles downstream from crossing \#4.

As shown in Figure B.9, the turbidity varied across the downstream monitors with time; however, the center sampler consistently collected samples with the highest turbidity. A flowweighted average turbidity for the three downstream monitors was calculated and plotted versus time in Figure B.10. For the purpose of checking against the 10-day, 25-NTU standard, the running average of flow-weighted turbidity was plotted versus time in Figure B.11; this plot shows that compliance with the 25-NTU standard was not attained after 10 days.

Beginning with crossing \#4, the revised IDEQ conditions required the measurement of dissolved-oxygen concentrations and temperature of the water during instream construction. Dissolved oxygen was measured both upstream and $600 \mathrm{ft}$ downstream at regular intervals during the excavation and backfilling activities. No significant differences between upstream and downstream measurements were seen. Figure B.12 shows plots of dissolved oxygen versus time. On this figure, the upstream and downstream data points are superimposed and appear to be one line. Due to an equipment malfunction, no temperature data were taken at crossing \#4. 
Appendix D contains the dissolved oxygen and temperature data for crossing \#4 and the remaining five crossings.

\subsection{Crossing \#5}

For crossing \#5, the flow regime in the river $600 \mathrm{ft}$ downstream was complex. A submerged mound of cobbles immediately upstream of the sampling location had separated the flow into two thalwegs. The three sampler intakes were located at 17,37 , and $68 \mathrm{ft}$ from the left bank, where the river was $98 \mathrm{ft}$ across. The right and left sampler inlets vere located in the two thalwegs; the right and left thalwegs were 0.9 and $0.8 \mathrm{ft}$ deep, with current velocities of 2.5 - and $2.1-\mathrm{ft} / \mathrm{s}$.

Monitoring at crcssing \#5 began at 2:00 A.M. on August 19, 1992. As expected from previous experience, the divided flow regime led to higher turbidity at the samplers located in the thalwegs. As shown in Figure B.13, turbidity at the right and left samplers was generally higher, and turbidity measured at the center sampler was lower. The flow-weighted average turbidity was plotted versus time in Figure B.14. The time-weighted average of the flow-weighted average turbidity was plotted in Figure B.15; this plot shows that compliance with the 25-NTU standard was attained six days after the beginning of instream activities (eight days for the $95 \%$ confidence interval).

The turbidity associated with excavation activities was elevated for about 15 hours, with a peak turbidity of 683 NTU. The turbidity associated with the backfilling lasted about 10 hours, with a peak turbidity of 398 NTU. As shown in Figure B.16, both of these turbidity plumes were traceable downstream at sampling locations for crossings \#6 and \#8, 2.4 and 7.2 river miles downstream from crossing \#5. Both the dissolved oxygen and temperature in the river were marginally higher $600 \mathrm{ft}$ downstream of the construction activity than they were upstream. Dissolved oxygen and temperature are plotted versus time in Figures B.17 and B.18.

\subsection{Crossing \#7}

At crossing \#7, the depth profile of the river was relatively flat from the pipe crossing to the $600 \mathrm{ft}$ downstream sampling location, with the thalweg at the approxinate center of the river. As the bottom was relatively free of large boulders or other obstructions, the flow was not very turbulent, but the river was moving quickly. At the $600 \mathrm{ft}$ downstream location, the depth of the thalweg was $1.5 \mathrm{ft}$, with a current velocity of $2.0 \mathrm{ft} / \mathrm{s}$. The downstream sampling locations were 23,43 , and $68 \mathrm{ft}$ from the right bank. The river was $92 \mathrm{ft}$ across at this location.

Monitoring at crossing \#7 began at 2:00 A.M. on August 21, 1992. The turbidity associated with excavation lasted for about 18 hours, with a peak occurring at $858 \mathrm{NTU}$. The turbidity associated with backfilling lasted about 15 hours, with a peak turbidity of 3,567 NTU. 
As shown in Figure B.19, both turbidity pulses reached the sampling location at crossing \#8, 4.0 river miles downstream, in approximately six hours.

Figure B.20 shows the turbidity measured at each of the three downstream sampling locations and indicates that turbidity was more evenly distributed across ihe river. This result is consistent with expectations in a monolithic flow regime. The only substantial exception to this observation occurs at hour 39, when the removal of the BMP flow barriers sent a turbidity pulse downstream that registered higher values at the left monitor. The turbidity measurements at this sampler during this event were the highest observed in the entire Project, reaching over 3,500 NTU. The flow-weighted average turbidity was plotted versus time in Figure B.21; the time-weighted average of the flow-weighted average turbidity, plotted in Figure B.22, shows that compliance with the 25-NTU standard was not attained after 10 days. The dissolved oxygen and temperature measurements taken during instream construction activities are shown in Figures B.23 and B.24. The data show no tendency for either parameter to be higher or lower downstream than upstream.

\subsection{Crossing \#2}

At the transect $600 \mathrm{ft}$ downstream from crossing \#2, the river was wide and shallow, with two main thalwegs. These two thalwegs were caused by channeling around an island in the river another $20 \mathrm{ft}$ downstream of the sampling transect. The river was $160 \mathrm{ft}$ across and $1.2 \mathrm{ft}$ deep at the left thalweg and $1.1 \mathrm{ft}$ deep at the right thalweg. The right, center, and left samplers at the $600 \mathrm{ft}$ downstream location were 25,65 , and $120 \mathrm{ft}$ from the right bank.

The equipment removed from crossing \#7 was set up at crossing \#2, and sampling began along with excavation at 7:00 P.M. on August 25, 1992. Excavation stopped for the night at 12:00 A.M. August 26 and resumed again at 7:00 A.M., continuing until midafternoon that same day. The peak turbidity level observed was 1,181 NTU. The pipe section was pulled across the river and backfilling began at about 5:00 P.M. Backfilling, with turbidity levels peaking at 1,783 NTU, was completed late in the evening of August 26. The plume from this crossing was observed with a peak of $91 \mathrm{NTU}$ at crossing \#8, 15.5 river miles downstream, about 34 hours after it was generated. In Figure B.25, a plot of turbidity versus time for all of the samplers downstream of crossing \#2 show the progression of the plume as it moved downstream.

As shown in Figure B.26, the highest level of turbidity across the stream was not always in the same location. The plume generated by the excavation phase had its highest levels measured at the right sampling location, while the plume generated by the backfilling phase had its highest levels measured at the left sampling location. Flow-weighted average turbidity is plotted versus time in Figure B.27; the time-weighted average of the flow-weighted turbidity, plotted in Figure B.28, shows that compliance with the 25-NTU standard was not attained after 10 days. Dissolved oxygen and ternperature were only measured on two occasions during instream activities at crossing \#2. Both plots, in Figures B.29 and B.30, show little difference between upstream and downstream measurements for either parameter. 


\subsection{Crossing \#1}

At the transect $600 \mathrm{ft}$ downstream from crossing \#1, the river was wide and shallow, $115 \mathrm{ft}$ across and $0.7 \mathrm{ft}$ deep near the left bank. There was no apparent thalweg, so the samplers were evenly spaced at 30,60 , and $90 \mathrm{ft}$ from the right bank.

The equipment removed from crossing \#2 was set up at crossing \#1, where sampling began on August 28, 1992, at 7:00 A.M. The morning was spent preparing the flume bridge, and ctual excavation was started at 11:00 A.M. Peak turbidity levels reached 2,652 NTU during excavation, which was completed by midafternoon the same day. The pipe was pulled across the river, and the trench was partially backfilled before the crews stopped working at 7:00 P.M. In spite of the fact that the trench was open all night, the turbidity levels measured downstream returned to and stayed at background levels within one hour of the cessation of instream activities. Backfilling operations resumed at 8:00 A.M. the next morning and were completed by 5:00 P.M. that same day. Peak turbidity during backfilling operations was measured at 424 NTU. As shown in Figure B.31, the plume from this crossing dissipated relatively quickly as it moved downstream. The plume was observed with a peak of 31 NTU at crossing \#8, 16.4 river miles downstream, about 40 hours later.

As shown in Figure B.32, for both excavation and backfill, the turbidity levels were higher at the left-hand sampler $600 \mathrm{ft}$ downstream of the crossing than at the right-hand or center samplers. The flow-weighted average turbidity was plotted versus time in Figure B.33; the timeweighted average of the flow-weighted average turbidity, plotted in Figure B.34, shows that compliance with the 25-NTU standard was attained five days after the beginning of instream activities (eight days for the $95 \%$ confidence interval). Plots of dissolved oxygen and temperature are shown in Figures B.35 and B.36. Dissolved-oxygen concentrations did not change significantly and water teraperatures varied naturally, i.e., warm during daylight hours, then cooling at night.

\subsection{Crossing \#3}

An island in the river immediately upstream of crossing \#3 divided the river into two channels, and it was determined that each of these channels would require monitoring. At $600 \mathrm{ft}$ downstream, the river was only $75 \mathrm{ft}$ wide and $1.5 \mathrm{ft}$ deep, with current velocity of $1.5 \mathrm{ft} / \mathrm{s}$ at the thalweg. The three samplers were set up at 25,40 , and $55 \mathrm{ft}$ from the right bank. As the thalweg was off-center to the right, the right sampler was located further towards the center of the river than normal, in order to obtain samples more representative of the thalweg. Figure B.37 shows that for the majority of the construction activity, the center sampler received the highest turbidity.

Excavation at crossing \#3 began at 5:00 P.M. on August 31, 1992, continued until around midnight, and resumed again at about 6:00 A.M. on September 1. A peak of 1,200 NTU was measured during this phase. Because construction crews experienced difficulty with the trench walls caving in, and because storage space for these excavation spoils was limited, 
excavation was not completed until late afternoon on September 1, at which time the pipe was pulled across the river. Due to the limited space, the bulk of the spoils could not be returned to the trench until all the pipe connections on land were completed and backfilled. Thus, the trench remained open for the next 36 hours, before backfilling was able to begin briefly on the afternoon of September 3. The crew worked only until 8:00 P.M. on September 3 and resumed backfilling operations on the afternoon of September 4, working until nightfall. A peak of 1,400 NTU was measured during this phase. On the morning of September 5, crews returned one final time to remove the flow diversion structures. A spike of 315 NTU was measured when the suspended sediment held back by these diversion structures was released into the river. All samplers were removed on September 6 except for the center monitor $600 \mathrm{ft}$ downstream of the crossing, which was to remain until the rock bridge upstream was removed.

As shown in Figure B.38, the plume from the excavation at crossing \#3 reached a peak level of $211 \mathrm{NTU}$ at crossing \#8, 10.3 river miles downstream, about 24 hours after it was generated. The flow-weighted average turbidity was plotted versus time in Figure B.39; the timeweighted average of the flow-weighted average turbidity, plotted in Figure B.40, shows that compliance with the, 25-NTU standard was not attained after 10 days.

Figures B.41 and B.42 show that there were no significant differences between upstream and downstream dissolved oxygen and temperature measurements.

A total of five samplers were operated at 30-min intervals for the five-day duration of construction activities at crossing \#3. In addition, automatic samplers remained in operation downstream at each of the previous seven crossings, sampling at 60-min intervals. With these 13 samplers in operation, nearly 2,100 turbidity samples, about one-third of all the turbidity samples processed for the whole Project, were collected and analyzed during this period.

\subsection{Rock/Bridge Removal}

Argonne did not document the dates and times of the rock/flume bridge removals; however, sampling equipment was kept in operation until all instream activity upstream of a sampler was completed. In this way, if a distinguishable plume were generated by a rock/flume bridge removal, it would have been detected. As described below, the rock/flume bridge removals at crossings \# 1 and \#2 were the only removals that generated distinguishable plumes. The following is a summary by crossing of our measurements and observations of turbidity associated with the rock/flume bridge removal operations.

Crossings \#1 and \#2. Rock/flume bridge removals at each of these crossings generated a brief spike (lasting one to two hours), with a peak of about 200 NTU at the sampling location $600 \mathrm{ft}$ downstream. The pulses dissipated quickly, and levels of about 20 NTU were detected at the upstream monitors still in operation at crossing \#3, which were 6.2 and 5.3 river miles from crossings \#1 and \#2. 
Crossing \#3. The rock/flume bridge was removed at the same time the BMPs were removed. Therefore, the turbidity contribution from the rock/flume bridge removal was coincided with the turbidity generated by the other instream activities. All these activities were monitored and documented as part of the previous discussion of crossing \#3 (Section 3.8).

Crossing \#4. The rock/flume bridge removal did not generate a turbidity plume that was distinguishable from the turbidity plumes being generated at thame time by activities at crossing \#3.

Crossing \#5. Turbidity caused by the rock/flume bridge removal was missed due to a sampling-equipment malfunction.

Crossings \#6, \#7, and \#8. Although samplers were operating downstream of the rock/flume bridges during removal operations, these removals did not generate plumes that were distinguishable from other plumes that could be attributed to instream activities taking place at crossing \#3.

Also, as background turbidity levels by the end of the Project were ranging between 5 and $10 \mathrm{NTU}$, it is possible that the rock/flume bridge removal plumes at crossings \#4, \#6, \#7, and \#8 were indistinguishable from background turbidity. This amount of turbidity is insignificant relative to the turbidity levels during construction activities.

\subsection{Correlation of Total-Suspended-Sediment Data with Turbidity}

Correlations between total suspended-sediment (TSS) concentrations and associated turbidity (measured in nephelometric turbidity units) were developed from data collected for the GRI study. In the GRI study, water was sampled at crossings \#1, \#3, \#5, and \#8 using Manning water samplers. These samplers, which operate in a manner similar to the ISCO water samplers used for the Bechtel monitoring program, were set up at four to five transect locations at each crossing and were operated for the duration of the construction activities at that crossing. The frequency of the sample collection varied from 30 min during peak activity to 60 min during less active periods. The first sampler was placed upstream of the crossing to measure background levels of turbidity. The second sampler was placed immediately upstream of the rock structure. The third sampler was placed directly downstream from the rock structure. The fourth sampler was placed $600 \mathrm{ft}$ downstream from the crossing. At some crossings, a fifth sampler was set up to sample at downstream or upstream locations. Grab samples were also taken during periods of peak construction activity. Data from these grab samples are also included in the TSS/NTU correlations. Crossing \#8 data are not included in the correlation analysis because interest in correlating TSS concentration and turbidity did not arise until after the crossing \#8 TSS analysis was completed for the GRI project. A total of 1,446 data points from crossings \#1, \#3, and \#5 were used for correlation purposes. 
The samples taken with the Manning water samplers and the manual grab samples were shipped to ANL and analyzed in the laboratory for both TSS concentration and turbidity. The procedures used to measure turbidity were identical to those used for the Bechtel study. A 20-mL aliquot was removed from the agitated sample container, diluted if necessary, and analyzed in the nephelometer. The test procedure for determining TSS concentration consisted of filtering the entire sample for suspended solids, measuring the amount of water in the sample bottle, drying and weighing the suspended solids, and calculating the total suspended solids. Separate TSS/NTU correlations for crossings \#1, \#3, and \#5 are presented in Figures B.43, B.44, and B.45. Figure B.46 shows a plot of the TSS data versus turbidity for all three crossings combined.

The slope and regression coefficient values were calculated using the "least-squares" method for a best fit of the data to produce a straight line. The equation for a straight line can be used with the least-squares method and statistically tested to prove if a straight line is an appropriate model. The equation is written as

$$
Y=B_{0}+B_{1} X
$$

where

$$
\begin{aligned}
& B_{0}=Y \text {-intercept, } \\
& B_{1}=\text { slope, } \\
& Y=Y \text {-axis value (TSS), and } \\
& X=X \text {-axis value (turbidity). }
\end{aligned}
$$

The values of $B_{0}$ and $B_{1}$ must be estimated such that they have the smallest possible sum of the squares of deviations, $S$. The quantities $B_{0}$ and $B_{1}$ are replaced in the equation with $b_{0}$ and $b_{1}$, which are statistical estimates of the slope and $\mathrm{Y}$-intercept. The equation is rewritten as

$$
\ddot{Y}=b_{0}+b_{1} X
$$

where

$$
\begin{aligned}
& \mathrm{b}_{0}=\text { estimated } \mathrm{Y} \text {-intercept, } \\
& \mathrm{b}_{1}=\text { estimated slope } \\
& \ddot{\mathrm{Y}}=\text { predicted value of } \mathrm{Y} \text { (TSS) for a given } \mathrm{X}, \text { and } \\
& \mathrm{X}=\mathrm{X} \text {-axis value (turbidity) } .
\end{aligned}
$$


Using the following statistical formulas for $b_{0}$ and $b_{1}$, an estimated regression equation can be written (Draper and Smith, 1966) to correlate TSS and turbidity for each crossing.

$$
\begin{gathered}
\mathrm{b}_{1}=\frac{\left[\Sigma \mathrm{X}_{\mathrm{i}} \mathrm{Y}_{\mathrm{i}}-\left(\Sigma \mathrm{X}_{\mathrm{i}}\right)\left(\Sigma \mathrm{Y}_{\mathrm{i}}\right) / \mathrm{n}\right]}{\left[\Sigma \mathrm{X}_{\mathrm{i}}^{2}-\left(\mathrm{X}_{\mathrm{i}}\right)^{2} / \mathrm{n}\right]} \\
\mathrm{b}_{0}=\mathrm{Y}_{\mathrm{avg}}-\mathrm{b}_{1} \mathrm{X}_{\mathrm{avg}}
\end{gathered}
$$

where

$$
\begin{aligned}
\mathrm{i} & =\text { individual sampling point, } \\
\mathrm{n} & =\text { total number of samples, } \\
\mathrm{Y}_{\mathrm{avg}} & =\text { average value of } \mathrm{TSS}, \text { and } \\
\mathrm{X}_{\mathrm{avg}} & =\text { average value of turbidity }
\end{aligned}
$$

The numeric value equations calculated are shown in Figures B.43-B.46. Table 1 shows the range of values for the crossings. The data and further analysis of the TSS/NTU correlations are included in the GRI report. This preliminary information is being provided for reference courtesy of the Gas Research Institute.

TABLE 1 Range of TSS Values Calculated Using the Least-Squares Regression Equations

\begin{tabular}{lcccc}
\hline & \multicolumn{4}{c}{ TSS at the Given Turbidity (mg/L) } \\
\cline { 2 - 5 } Crossing & 250 NTU & 500 NTU & 750 NTU & 1,000 NTU \\
\hline \# 1 & 262.8 & 513.1 & 763.4 & $1,013.6$ \\
\# 3 & 315.6 & 630.3 & 944.9 & $1,256.0$ \\
\# 5 & 380.9 & 778.1 & $1,175.4$ & $1,572.7$ \\
$\begin{array}{l}\text { \#1, \#3, \#5 } \\
\text { combined }\end{array}$ & 310.5 & 612.2 & 914.0 & $1,215.7$ \\
\hline
\end{tabular}




\section{Conclusions and Recommendations}

The primary goals of (1) monitoring turbidity levels downstream of the pipeline crossings in accordance with the IDEQ Section 401 water-quality certification and (2) providing decisionmakers with field data characterizing the short-term increases in turbidity appear to have been achieved. No interpretation of the data beyond that necessary to meet the requirements of IDEQ is within the scope of this report. The following general observations, however, deserve to be summarized:

- Mixing of suspended sediments across the river cross section was not complete $600 \mathrm{ft}$ downstream of the crossing. Even in a river as turbulent as the Moyie, enough channelized flow existed to prevent complete mixing and homogeneity across the stream section. At distances up to $0.5 \mathrm{mi}$ downstream of the crossing, uneven turbidity across the river was still observed. This uneven mixing presents a problem when trying to take samples representative of the overall turbidity.

- The turbidity plumes observed were extremely persistent. The plumes generated at the northern crossings (\#1, \#2, \#3, and \#4) had turbidity levels far above the IDEQ standards, even after they had traveled several river miles downstream. Less is known quantitatively about the persistence of the plumes generated by the southern crossings (\#5, \#6, \#7, and \#8), but visual observations suggest that they were as persistent as the other plumes.

- Dissolved-oxygen concentration and temperature of the water downstream of the crossing construction were not affected by instream construction activities.

- The ability to make qualitative judgments and comparisons about the effectiveness of the BMPs in reducing turbidity downstream of construction activities is hindered by the variability of such factors as subsurface information, types of BMPs utilized, amount of material removed, duration of construction activity in the river, and river flow rates between crossings. However, several BMPs appeared to be ineffectual when field-tested (notably, dewatering) and were, by consensus, discarded at later crossings (Bechtel 1993). Future decisions regarding the use of BMPs on similar projects should take into consideration the anticipated effectiveness of the structure and whether the extra time and instream activity associated with BMP installation and removal yields a net decrease in the mass of sediment released downstream. Such a decision-making process would be aided by performing a subsurface investigation prior to the start of construction.

The data collected for the GRI study, when combined with the data obtained from this study, will provide more insight into the behavior of the sediment plume as it moved downstream. The extensive sampling performed as part of the GRI study, at the three transects between a 
crossing and $600 \mathrm{ft}$ downstream of that crossing, yields information into how quickly sediment dropped out immediately downstream of the crossing, while the data obtained for the Bechtel study provides information on the sediment plume further downstream. General estimates of the total mass of sediment deposited on the river bottom by all the crossing activities may also be calculated from the resulting correlations. 


\section{References}

Buchanan, T.J., and W.P. Somers, 1969, "Discharge Measurements at Gaging Stations," chapter A8, book 3, in Techniques of Water-Resources Investigations of the United States Geological Survey, U.S. Department of the Interior, Washington, D.C.

Clesceri, L.S., A.E. Greenberg, and R.R. Trussell, 1989, Standard Methods for the Examination of Water and Wastewater, 17th ed., American Public Health Association, Washington, D.C., pp. 2-11.

Draper, N.R., and H. Smith, Jr., 1966, Applied Regression Analysis, John Wiley \& Sons, Inc., New York, N.Y., pp. 1-35.

Idaho Division of Environmental Quality (IDEQ), 1992, IDEQ 401 Water Quality Certification Amendment, letter from G.P. Burr (IDEQ) to M. Doherty (U.S. Army Corps of Engineers) and M. Luttrell (Bechtel Corp.), August 7, reprinted in Appendix A.

Luttrell, M.E., 1993, personal communication, Bechtel Corporation, San Francisco, Calif.

Pacific Gas Transmission and Pacific Gas \& Electric (PGT-PG\&E), 1992: Final Moyie River Fisheries Enhancement Plan, submitted to the Federal Energy Regulatory Commission (FERC) on June 19, FERC Docket No. 6P89-460-000 et al. 
Appendix A:

IDEQ Monitoring Requirements 
Appendix A:

\section{IDEQ Monitoring Requirements}

Attached are the two letters from IDEQ outlining the water-quality monitoring requirements for the Pipeline Expansion Project. The first letter, dated January 14, 1992, outlines the original requirements that were applied to Crossings \#8 and \#6. The second letter, dated August 7, 1992, outlines the revised monitoring requirements that were applied to the remainder of the crossings. 


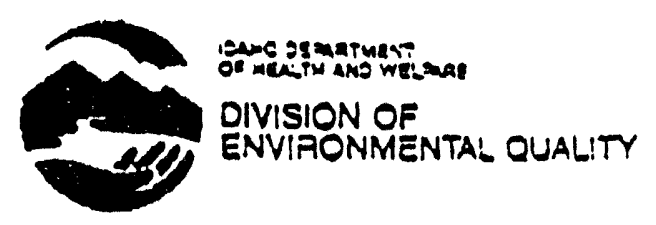

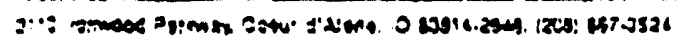

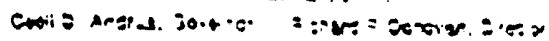

January 14,1992

PGI-PGE PIpeILne Expansion Project

45 Fzosont StEoet, $3 / 033$

San Erancisco, CA 84119

SEFERENCE TO: Depazement of the Awy propased perail io.: OYC-2-003819 (Various streama ane votlarias ir. 3ounda=y, Bonnaz, and Kootanat Countles, Ieahol

Gartleman:

We have conshdered water quality certletcation of your jzogosal to

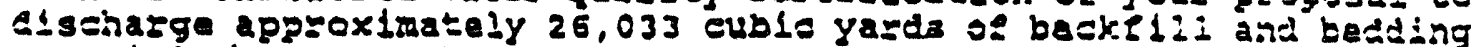
material in several nerts Idaho waters in absocils esnstzuteisn of a 42 l.neh natural gas tra.rsfissis: itne as duscribed is publ1c nst:ce number 071-0Yc-2-0036is.

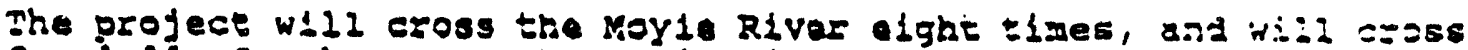

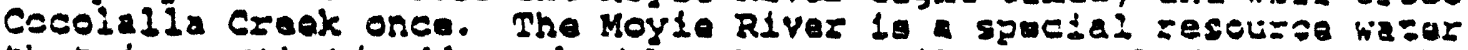
that is aestheslcally valuable, howeves the uoe of the st=ead by cold water blota io limitac, and few ripazian zesflenss dzaw domestie watar gron she rivar.

cocolalla creak to telbutary to cocolalba lake. Thio osias is sompletirg a Phase I EPA Clean Lakn trvectigsticn on cocela:ia Lake in which nutrionts and oedments have bean idens cont=ibutore to lake degradation. Pbase II zoney wili juglement ways to zeduce shese discbazges. It would be irapprofilate to sertify a process (direct oediment dischagge via wat irenching) That has been 1dentizied an contributing to laxe dograsatisa.

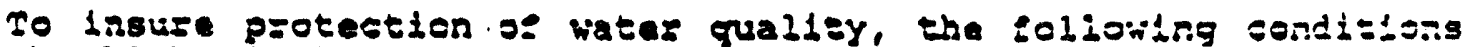

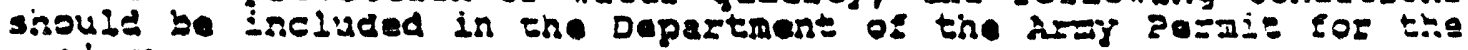
pะojos::

Bpr the Moyle River czosalings:

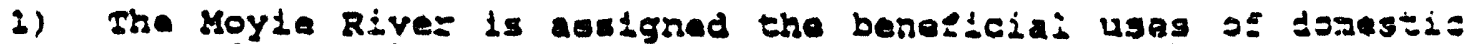
water aupply, agziculsural waser suppiy, cold wasaz bioth, sadaonis

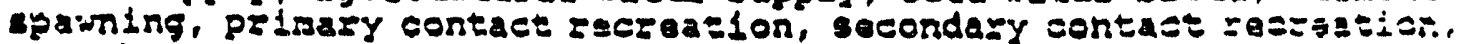
as wall as the general use deslgnations of Industzial wasa sigpiy.

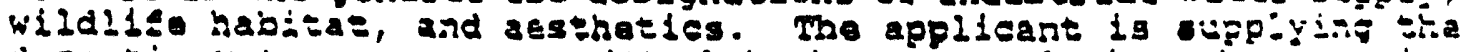

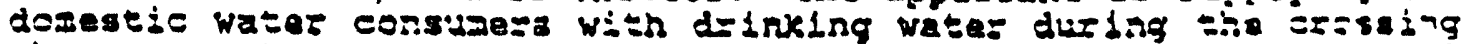
ohases os the project, hence domestle watar supply soreeras ini:-

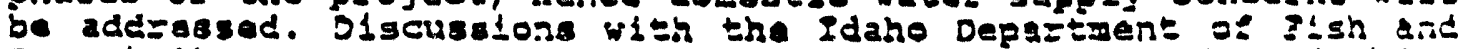

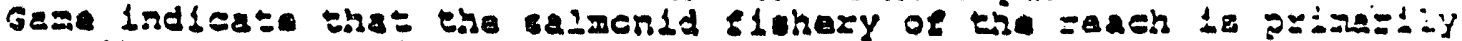

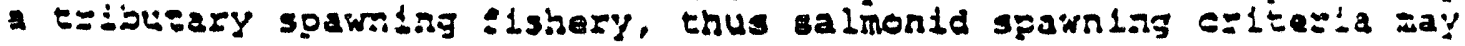


net be approprlate. The bereg1=12l upe most jeopard12ed oy the projost is that of cold water biota. The applicant ass!i nanitor

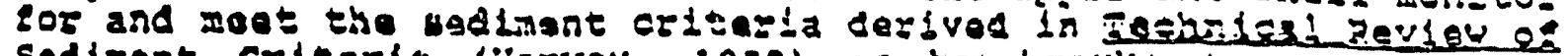

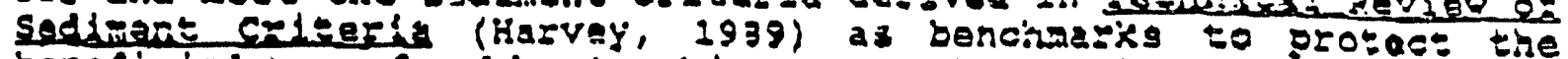

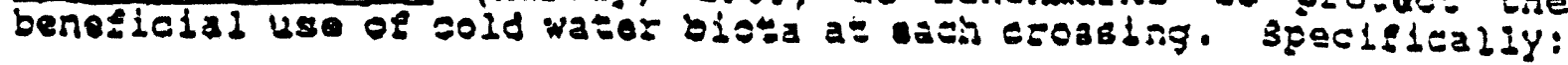

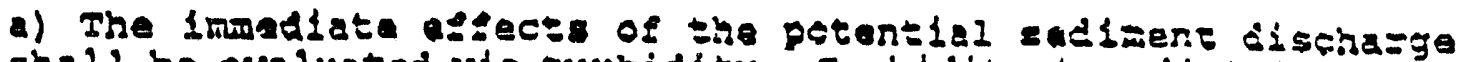
shal t be evaluatod via vurkidity. Turbidity dasodiately below a mixling zone of 600 fant, as the rasult or the grojest, shall

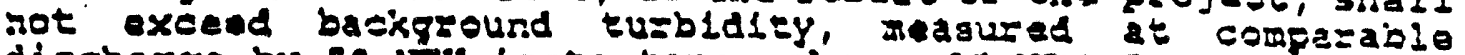
dischazge by 50 dive instantariecusiy or 25 Nitu sos io days.

Background shall be deflised for tha pusposas of tis projece as an aras lacedlateiy upserean of eash erosging triat is nos ixfluenced by cressing activity.

Monitering by whe poplicart shall be gu:ficienty troguent to

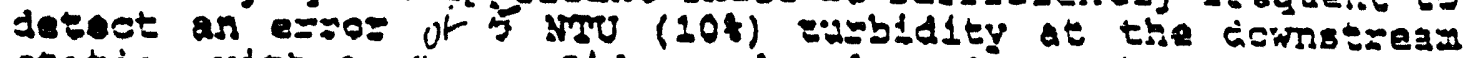
seation wien a is joreidence level. Th nimber of 8 mples w1ll depend on the varlabllity of the turkisity. The applicant is axpectad to determine tha variabilis?, asd to wodify the sampling Ezaguency uccordingly.

The distance of 600 feat is a Best prosessionsl Iujgarent of the distance needed or diszipation basud on roperts of othez ozesalngs gupplled by the appilcant and linits appiigd by the

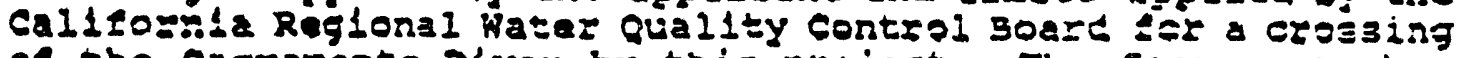
of the saczamento River by this ptoject. The gacramanto tss andilaz bottem and supforts spawning habliz: E0: salmon, an endengerad speries.

Should the turbldity cżteria te exceoded duriag ino project, the appiscant must exploy additiond or distezens BM? teshrigues to soduse the dischazge.

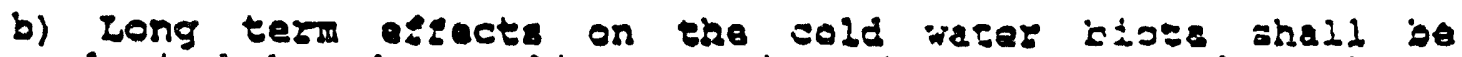
-valiated by the applicant using the pszaent ambediedness criterion that: no etaslatlcaliy demonstrable 1rezease, at tho 953 confldance insorsal, in nasura? zassise pezcent

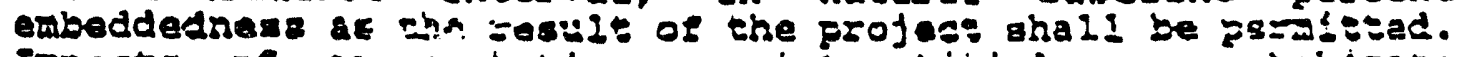
impacts of oejidantation on 1aterstitial gpass isbisass

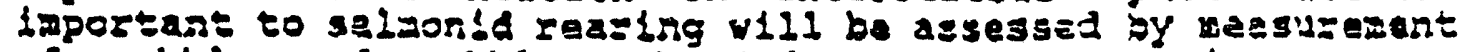
of cobble and rubble ambeddednus. chango in pareant

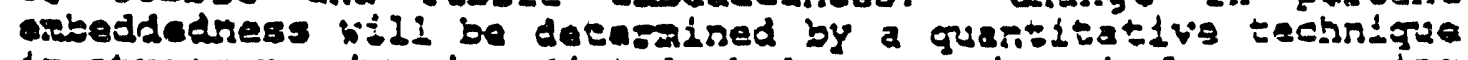
in stzed reacies immediataly below frossings beloze czosadry activity and in the same reach i peaz astar erossing completion. A fersent mbeddednoss value iill consizt of 2 wean it the 95 pacision level of the $E$ statistis.

Baseline arail be that condition in the cesches lamediately below tbe crousing locations bosore crassing cotivity is inltiatad. No minfulum distasce below crossings gisali dpply, 
however, samplo locatiens ghould be located so is to reasenably detect changes due to the profsos.

2) In add1tion to the above, and documenting the esfucts of ine project on benefletal uxas via a contreet study with the Gas Reaearch institute, the appldeant shall deteraina the lollowlng:

a) What, if any, predictive relationship axists between the componition of the erench abstrat and the anount of pedizent and tusbldizy generated by wat trench stzasu crossing.

b) The applleant shall evaluate the eftest tveness of the BMp technique of disturbance time minimization. proposes use of this thehrigue has been fivota: in the sulectios o: tae wet croselng technigne as the method with bro least wate: guality inpact. Assuming all elght croselngs w112 not sake exacsy tha eame arount of tioe, a theoretieal relarlonstip chould exiot between time of disturbasce and amount of turbldity genurated.

3) Coples of the above eurbldity data shall bo made aviliabla $=0$ this ofice after each crozsing. Exceedence of the criteria ghall be dmadiataly reported. Coples of the aboddednass lata, Gas Reseazch Inetltute report and 1 tans $2 a$ and $2 b$, above shall be submitted to infs effice upos completion.

4) This offsce ahall be notifled of the start and compistion os

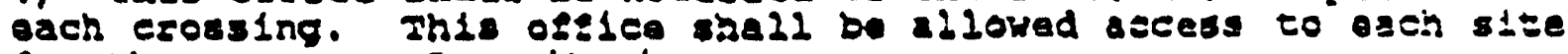
ter the purpose of monitoring.

3) The applicant shall supply potable srade waser dizing the exossing phases of the project to drose domestic weter diass that

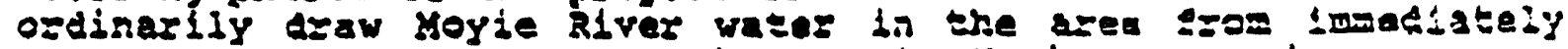
above the most upotream crosidrg to the Hoyie Reservel.

For the cocolalia creek croselng:

6) A lume or other alversion device is to be usad to divaze craek water guch inat excavation and backililing an be pertosuad in whe azy. Additsonal eurbidity controis may be neiked to prevant sedirant dischargo.

Fot all aspects of the project:

7) Ary appropriate BuPs, elther etrucsural or operstasnal, sha:l be employed and matntalned during upland activitiez to estertively

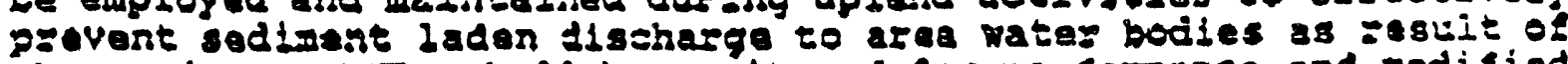
the profaee. Bips shall be monitered sor perzormance and pedisiod if unateiseactory.

8) No more than one atle of conthuous trench shall be open at a glves elase. 
9) Eculpreat wall be opezated in the water only for the purposa of instailing Llsh structures, trenchlng for tho plpo, fipo laying, and back-eliling. casual or conventenos opezation of arsiprent ia any water body shall not be pezmittod. Absorbant booms and pada snall be on site in the event of a disharge of potrolais products. Ihis offle $1 \mathrm{~s}$ to be notdfied of uld alsenargas.

10) No dischazge of hydrostatic tast water 1s ajthorized by this cazeilication.

13) Trenoh pusp water shall not be difsctly of lindsestly dischazged to wetlands or otreams.

12) Rervegetation of dlsturbed ripazian and wotrand areas shall be accomplishad with nativo vagetation.

IE construction 1s completed in accordance with tho alscribed work plan and above conditions, we can ceztlify under sacsion 401 that this construction will comply with applicale gequirements of Sectione 301, 302, 303, 306, and 307 of PL 92-500, as amented, and

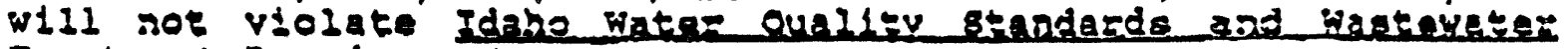
Treatimant Reoustrenghe.

Thls certifleation doss not imply approval of the aztivity by oener agencies of the stare of Idaho.

sincerely.<smiles>CC1CC1C#[14C]C#[14C]</smiles>

Gwen Burs

Ragional Ndminlstrator

Comounity Rzograma

North Idaro Reglonal ostico

68:be

SC: IDWR-Northern Reglon-haymes, Rnoblock

DzO-P\&z-YOdez

DEO-NIzO-Cochrane, TuIIoch

Corpg-Nalla Walla-srkel

corps-Coeur d'Alene-boherty

EPA-BOL EN-YCEALI

IDFG-Conur d'alene-Corsi

usfis-Coeur a'Alene-Halleck 


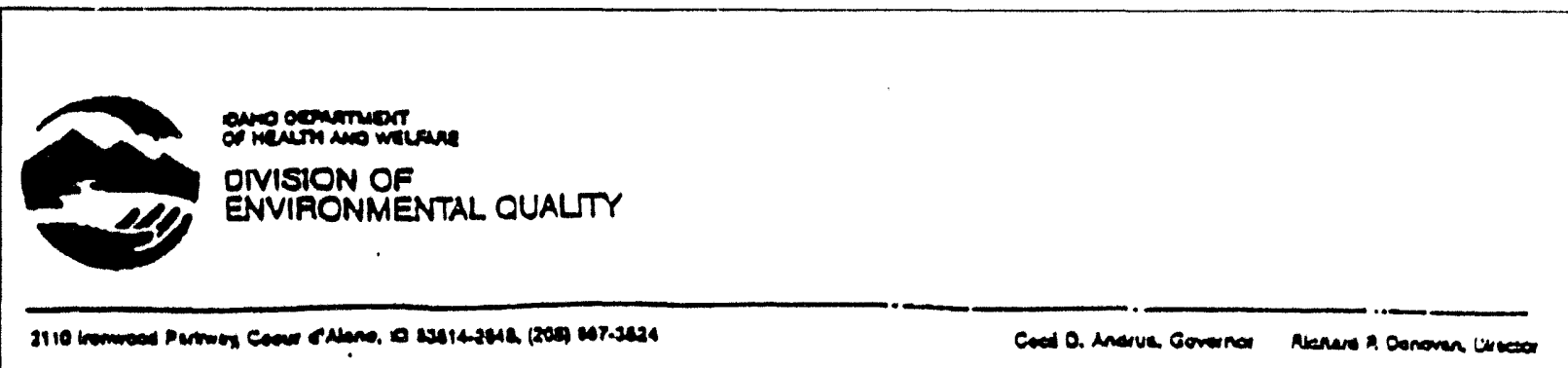

August 7, 1992

MF. Mike Doherty

o.s. Army Corps of Engineers

Walla Walla Dletrlet

1201 Ironwood Drive

Coeus d'Alene, ID 33314

Pecific Gas Transmisaton $\mathrm{c} / \mathrm{O}$

Mark Luttrell

Bechtel

P.O. Box 5606

Bend, OR 97708

RA: PGE/PGT PIPeline project; NPW 071-OYC-4-003819

Response to applicant revisions request of August 4,1992 and modiflcation of certiflcation condltions.

\section{Gentlemen:}

We have revlewed the applicant's reguest to modlfy the subfect permit and approve proposed Best Management Practices (Bxpa) Lor turbidity control so they ray cont1nue work on the remaining six gas pipeline crossings of the Moyie River. As discusen in the meeting ruesday morning $(8 / 4 / 92)$ with the applicant, we have additional concerns about domestic water supplles below the Moyie Reservoir. We also have some concerms that additlonal monitorling la roquifed to fully describe the 1mpacts assoclated with pipaline construction. The following sections of thls letter addrese these three toplc areas: proposed BMPs, domestle water eupply, and monitoring neads. DEQ's orlginal certifleation conditions require amendment given the requestad permit modifleations and ovents related to construction. certiflcation condltions to ansure water quality protection and compliance with Idaho Water Quality Standards are Included in a summary.

Proposed Bros.

The purpose of the non-polnt source arp seedback loop in the Idaho Water Quallty standards is to manage non-point source (NPS) discharges In a reasonable, proventative, and cost-effectlve manner. Bups for tradltional non-point sources have been relined to the polnt that once - ita conditions are known, they can be prascribed to a luvel that adequately controls the discharge. During the development of cartiflcation for thls pernit, the lta conditlons were unknown, as was the BMP effectivenesa and practical1ty. The applicant maintained that any pollutant (lncluding sediment) has two components with 
reepect to toxicity to aquatic blota: duration and concentration. Their proposal was to reduce the duration aspect of the equation to the minimum. DEQ essentlaliy agreas with this strategy, however, if concentrationi (In this case turbldity) are great enough, then impacts to the blota may occur no matter how short a time they ara exposed to the pollutant. For this reason, $50 \mathrm{NTU}$ was set as a certiflestion condition and BMp modification was required if turbidity exceeded that level. The 50 NTU value was derlved by many tachnical opecial1sta trom Industry, academia, and agencles as the polnt at whlch deleterious effects to salronlds occur. The document describing the analysis is titled rechnical Reviow of sediment Critorla (Harvey, 1989) and is anclosed.

Strategy used to select BMPs for controling NPS poliution is somewhat akin to buying insurance. The ldea is to select the correct amount of protection, given knowledge of existing conditions and the estimated risk that a discharge event will occur. Applying minimal BMpe in a nlgh riak atuation does not provide adequata protection for the resource. At the same time, one does not wish to pay for coveraga that way not be needed.

Iraditional NPS sediment control strategy also employs the concepts of disturbance minimization, source control, exclusion or transport mechanisw, flitration, and collection in that sequence. For example, in an erosion control situation, one would first minimize the amount of soll disturbed, then try to establish vegetation while excluding rainfall and runofe using dralnage control and some temporary soil cover, fliter the runoef as close to the source as possible using silt fences or the l1ke, then, as a last resort, settle the sediment out of the runofl. The idea is to keep the matarlal at it's source or remove it from the aquatic ecosystam.

DEQ submita that the proposed BMPs underinsure the profect. We now know material under the rlver bottom is easlly surpended, therefore, a high level of sedisent control affort is required to achieve resource protection. By virtue of the constralnts placed on sedirent control by construction technigues in a lowing channel, the most deslrable control atrategles; disturbance minimization (the trench must be dug), and source control (exposure of the source is not the problan, exponing it 10) ara eliminated from use. BMp stratagy used by the project must therefore place great omphasis on the remaining three concepte avaliable: exclusion of water (transport mechanism), illtration, and collection.

The proposed two or three BMpa, given the hlgh turbidity lavels that have resulted Iron the project, cannot reasonably be oxpected to achleve the $30 \mathrm{kHO}$ condition of cartiflcation if used singly. If the proposed BMp aro used in concert, raductions in turbidity from the next crosalng may be observed. Partlal axcluation of water from the areas of active trench digging will ilkely serve to somevhat retain the colloidal material that is contributing to the turbldity, however, this material will migrata downstream via a venturl offect from the 
water diverted around the equlpment or when the flow is returned to the shelterad area. Flitration using gravel trench plugo or pliter Labric may also tomporarily contaln turbldity, but agaln, whon tha pliter 1s removad, turbld water will be discharged. Collection of the turbld water needs to be an essentlal component of this plan to zemove the turbidity from the syster.

The following additional BMPs or crossing methods attenpt to maximiza the camaining three avallable concepts discussed above. They are presented is no particular order, however, we recognize that each has a dfferent effectlveness, logistlcal considerations and cost. Some of the ldeas may be comblned with the proposed BMPs for greater turbidity control.

a) Pumping the araas of extrame turbldity hae been suggestad in recent meet Ings and noted above. If the pollutant 1 g removed from the system at 1ta source, 1t will not lmpact resources downstream. Cara will have to be taken to ensure that adeguate flow romains in the stream channel and that pump operation does not create additional turbidity via leakage.

b) Complete lsolation of the work area may be possible by extending the ideas in the proposal submittad by the applicant. Using highway barriers and ellt curtain meterial all the way around the work area would allow greater containment, provide a structure for attaching flltar fabric, and may eflectively control turbidity from the digging operation. Sequential placament of work areas, cimllar to the tachnique in the appllcant' proposal, would allow the rlver to slow around 1solated activity. Basentialiy, a rectangle (or any other shape) of highway barriers could be placed around an excavator, the trench and epoll area; ellter sabrio could be attached to the barzlers; and the center portion of the tranch dug. The bodles of the excavators could be outside the enclosura. Once the centar of the trench is completed, flow could be gradualiy ra-routed through the center, the sides of the channel could be olmilarly isolated, and the trench completed. The folnts between the canter and sides may have to be broken without beneflt of contalnment, or some ilter mediun could be enployed lmilar to the applicant's Bup 13 . Combined with pumpling, turbidity from the tronching activity should be greatiy reduced.

c) $A$ luver croseling was discarded during the application phase due to flow conalderations and ia still not favorad by the applicant due to timo consideration. We stili have not heard that a flume is technlcally unachlavabla. River flowe are extremely low this year, making a elume crossing a poosibility. the advantages from a eurbidity reduction standpolnt of working in the dry ara many-fold. No watar llows across the tranch area or spoll plle, thersfora no transport machanism axiata. Duration of excavation or matarial ancountered does not become an lanu (from a turbidity impact perspective). The trench can be made essentially any size to accomodate inatallation of the pipe and rlaers. Backilil can be 
accomplished without add1tional lmpact or stress to the resource anc blota. This concept should not be discarded lightly since entire crossings can be constructed without turbldity inpacts other thar: thoss assoclated with placement and removal of the flume.

d) Spoil removal to an upland location along with placement of clear. material as backill may also help reduce turbidity discharges. Certainly the "second slug" effect observed during the plrst twc croseings w11l be greatly goduced or eliminated. Additional turbidity assoclated with disturbance of the spolls by excavation activity would also be elfminated since spoll material would not be placed instraam.

a) A Inal suggestion takes the idea of tixe reduction a step further. Rather than complete each crossing all at once, excavation could be divided into shorter events. Magnitude of turbldity might be reduced, and duration of exposure could be changed from elght hours into (for axample) lour, two hour, exposures, Consultation with flahery experts, aquatic blologists, and the literature is needed to detarmine if several short small exponures wi'h rocovery perlods inbotween is better than one longer, intense exposure.

Domeatle rater supply.

The project has impacted the domestle water supply treatment plant for the City of Noyle Springs. During the application phase of the profect, tarbldity discharges past the Moyie Reservolr were not antleipated. Neter roviewing the city's flnished water turbldity treatment recorde, it is evident that the CIty may violate the 30 day maximum turbidity average of the drinking water regulations. Mora maportantly, the fact that much higher levels of turbldity are passing through the plant indlcates that pathogens such as giardia cysta may also be passing through the plant. Turbidity interferes with the disinfection process, theraby increasing the rlak of waterborn lilnes. The plpeline project must address the potential public health threat caused by thelr activity before approval for contlnued crossing activity can be granted.

The Moyle springs Water Systom serves a population of approximately 100 people. shore with an Intake pipe in the middle of the river. The intike is approximately $2 / 4 \mathrm{mi}$. down atream of tha dad for tha loy le Reservolr. The water Is pumped up a hill approximately 300 ' elevation to a packaged difect elitration plant. the maximum plant capacity is rated at $300 \mathrm{gpo}$ at a flitration rate of $5 \mathrm{gpm} / \mathrm{ft}^{2}$ under optimum vater guality conditlons. The plant has chemical pretreatuent (coagulation) without rapld nixing, bydraulic floceulation, gravity dual media ilitration and disinfection.

This type of illeration plant is only denlgned to 111ter water where turbldity lovels are <7-14 NW and where rapid eluctuations in turbldity does not occur. The plant is currently operating at peak capacity and elitration rate. It la not able to effectivaly liftar 
the water from the Moyle river at this time to provide sale drinking water to $1 t^{\prime}$ users. This la documented by the turbldity lavels sees. in the oparators daily turbldity $10 \mathrm{~g}$.

The most approprlate and protective measure to pursue would be to install a pump in the Clty's Insiltration well and to supplement any additlonal water from the Three M1le Water District. Modiflcations to the well will requira DEQ approval prlor to placing the water supply in earvice. The company is proceeding with this option.

Monitosing needa.

Several weaknesses in the monltoring plan prescribed by the original cartifleation conditlons are now apparent. DEQ requesta that monitoring be adfusted to better document the water quality lapacts
associated with the profect.

Turbldity plumes moving as dlscreet slugs downriver ware not anticipated at the time the certiflcation letter was writtan. Now that we know high levele of turbldity are moving to the Kootenal River conlluence (at least), a more complete description of these events is warranted. Documentation of travel time, duration, magnitude and distance moved is needed.

Bahavior of turbldity plume lmmedlately below the croseligg was also not known at the tiae the nonitoring requilrements ware drafted. It 18 apparent that the river is not wall ulxed at the required monitoring location $600^{\circ}$ downstream of each croseing and that turbldity is related to the location of the excavation. Dus to thls lack of mixing, duration and magnitude of turbidity events may be under-reported ince a single sample location in the center of the stream may misa high turbldity values assoclated with trenching at the sides of the Itver.

Activity other than trenching may be contributing to turbidity in the fiver. DEO would like monitoring to be occurring whenever any Instreas activity is taking place at a crossing, not fust whan trenching is occursing. Iris includes equipment croseing the river, Installation, modifleation, and removal of llume bridges, Bup inatallation. Ilan otructure placemant, otc. complate documentation of turbldst aneciated with pipeline crossings will aid underatanding of cumulaterve ipacte.

Aquatic blote way be experiancing other stress at thls time of year which aay be compounded by the high turbidity levels from the project. since ifver Ilow to extremely low thls year, tamparature may be hlgher than unual. Increased turbldity increases the hat retentlon capacity of water. colloldal naterlal discharged frow the project may exert an oxygen demand in addition. The combination of any one factor alone may not pose any thraat to the Ilshery, however, two or three strasses may combine and lopact the population. DEo therefore requasta that temperature and oxygen monitoring be added to the existing plan. 
Lastly, we request that monltoring be performed to determine what Impacts the turbldity is having on a harleguin duck brood observed in the area by the osfs. The monitoring plan should be to the satisfaction of the Forest Service. Wlldilfo use is considered a beneflclal use of state watars. Sensitive species merit extra consideration, given the unexpected blgh turbidity encountered. Trenching ahould occur at night to raduce turbldity impacts to sight leeding organisms.

certilleation amendmat conditions.

To Ineure protection of water quality, the following conditions should be included in the Department of the Army Permit modification for the project:

1) The applicant has stated that crossing 5 will be construeted next. For that crossing, all Bups proposed in the ubject request letter shall be employed at the same time, in combination. Idditlonally, the proposed axps shall be used in a sinilar manner during backililing to reduce turbidity associated with that activity.

2) In addition to the proposed BMPs, pumping of highly turbid water from leolated areas near operating equipmant, banind llow dellactors, or other areas of high turbldity shall occur to remove turbid water erom the system. The pumped water shall be land applied via oprinklers in a manner that it will not re-enter waters of the state. Fumpe mall be operated in a contalned area so leakage or spray associated with pump operation does not contribute to eroolon and turbidity. pumping of water may not appraclably raduce to mafority of flow in the river. The objective of pumping is to remove oniy turbld water.

3) Additional BxPs, such as those suggested above, ara required at luture croseinge (after Number 5 ) if the proposed BMp do not reduce turbldity below the 50 kis cartification condition previounly lasued.

4) If other cources of turbldity are ldentifled during erenching activity, action ahall be taken to eliminate or reduce that source.

5) sotivity that resulto in hlgh turbidity discharga, apaciflealiy crosalng. exeavation and backe111, shall occus at night to reduce the impact on ight leeding blota.

6) No excavation or other crossing activity shall occur until the clty of Moyte springe is provided with an alternate water supply. Inplitration well improvements are currently beling pursued. Approval of the altarnate water oyetem sust be obtalned from stave panner of this office. Tha following 
1tems are required before approval can be obtianed:

a. A Professlonal Englneer (PE) rogistared in Idaho wust supply plans and specifications for pump and plping modiflcatlons to DEQ. Detailed as-built plans must follow within one month of installation. b. The wall must be tast pumped for capacity and
recovery and results provided to DEQ.

c. The well water must be teated for rotal and Fecal Collform bactaria, 1norganic compounds, organic compounds, and radiological elements. The water must meet state drinking water standards.

d. A PE must oversee all work and coordinate with DEQ.

-. An additional well, pump, or water supply may be needed to meet the volume demands of the CIty of Moyle Springs.

7) Turbidity sonitorling samplers located below each crosing shall contlnuously collect turbidlty data for the duration of project, regardless or activity occurring at the lmmediate croseing.

8) During crossing sctivity, three samplers shail collect turbidity below the croseling. sampler intakes shall be located at the existing location on the thalweg and at locations between the thalweg location and water's edge on each side. The permittee shall report all raw turbidity data to DEQ following completion of each croseing.

9) A turbldity monitoring plan shall be developed and 1mplemented that addresese the long term offects on cold water blota and domestic water uppiles. Approval of the monitoring plan must be obtained exom DEQ before Instream activity in completed.

10) Turbidity plumes and "elugs" ahall be documanted and described is a report to DEQ. The results may be incorporated In the report required by original certiflcation condition numer 2. We description shall include size of the plume, duration, tine of travel, and how far downstean the plume la detectabie.

11) Tomperature and dissolved oxygen shall be monitored $600^{\prime}$ below ach crossing lmediataly before, during, and shortiy aftar tranching work is parformed at that crossing. The statistical requirements of the original cartiflcation condition number la shall apply. 
12) A macrolnvertebrate monitoring plan shall be developed and implemented that adequately describes the effect of turbldity from the project on leeding by Harlequin ducks observed downstreas of the project crossings. Approval of the monitoring plan must be obtalned from Bob Rlarich of the Bonnera Ferry Ranger Distrlct before crossing activity can resume. A separate report shall be developed and submitted to Kr. Klarich. Data shall be submitted after each crossing 18 completed.

13) All elnal reports and monitoring data raguired by this and the original certiflcation shall be submitted to this offica no later than elghteen months after completion of the last Moyie River crossing.

This amendment to our original certiflcation does not release the applicant from meeting any of the original conditions.

If construction is completed in accordance with tha described work plan and above conditione, we can certify under section 401 that this conetruction will comply with applicable requirements of sectlons 301 , $302,303,306$, and 307 of $\mathrm{PL} 92-500$, as amended, and w11I not violate Idahe water ouality standards and wastewater Treatment Reouirements. This certiflcation does not cover future modiflcations to the project.

Any person aggrieved by an action or inaction of the Division shall be afiorded an opportunity for a falr hearing upon request therefor In writing pursuant to chapter 52, t1t1e 67, Idaho Coda and the rules and regulations promulgated thereundar.

Mls certiflcation does not lmply approval of the activity by other agencles of the state of Idaho.

sincerely.

theren P. been

Gwen P. Buzr

Regional Administrator

North Idaho Raglonal orelce

Enclosure

G8:bc

cc: IDWR-Horthern. Region-Haynes, Rnoblock

DEO-CP-POOLE

DEO-AGE OEflca-Beaton

DEQ-HIRO-Cochrane, TInkey

CORPS-Coeur d'Alene-Doherty, Rayner

BPA-BOIse-0180n

IDFG-Coeur d'Alene-Cors 1

usFis-Coeur d'Alene-Halleck, Donaldson 
Appendix B:

Figures 


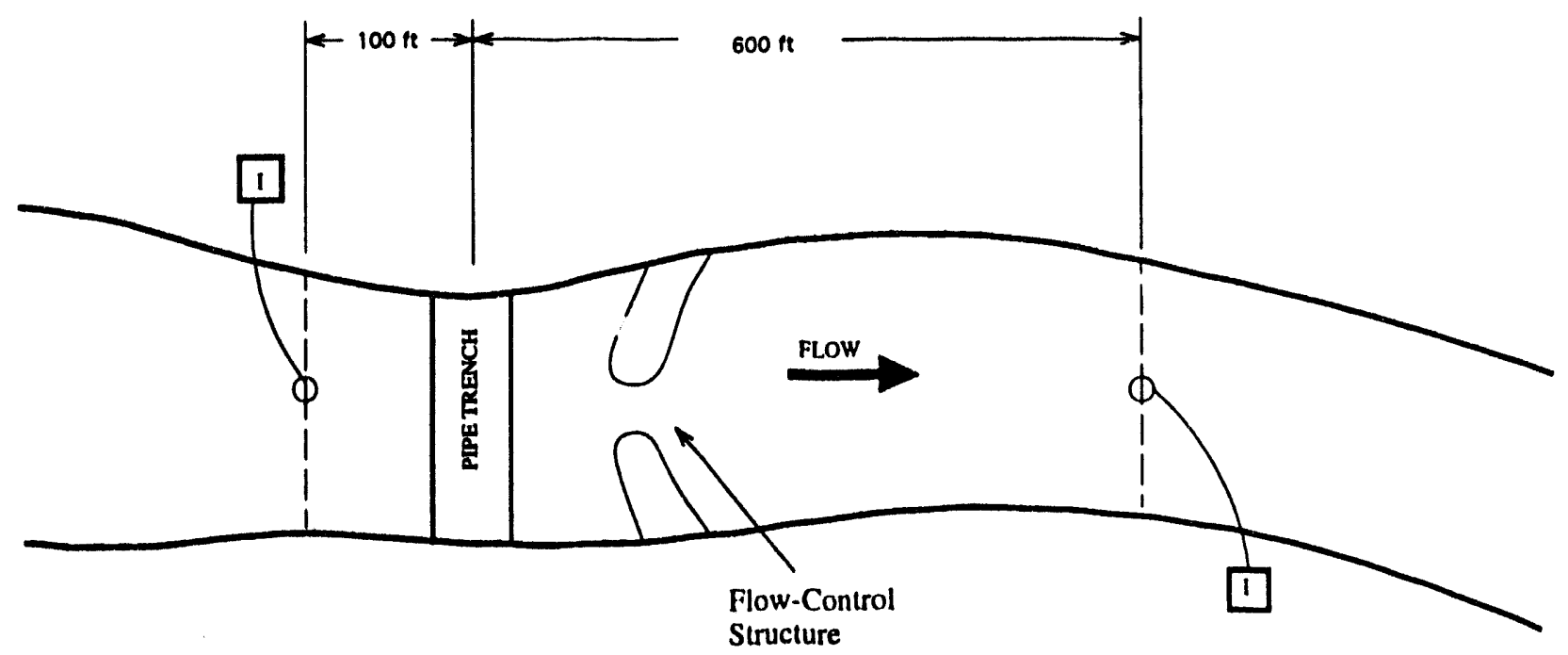

\section{LEGEND}

1 - ISCO Automatic Water Sampler

- Sampler Inlet / Strainer

NOT TO SCALE

FIGURE B.1 Schematic Diagram of Sampling Locations

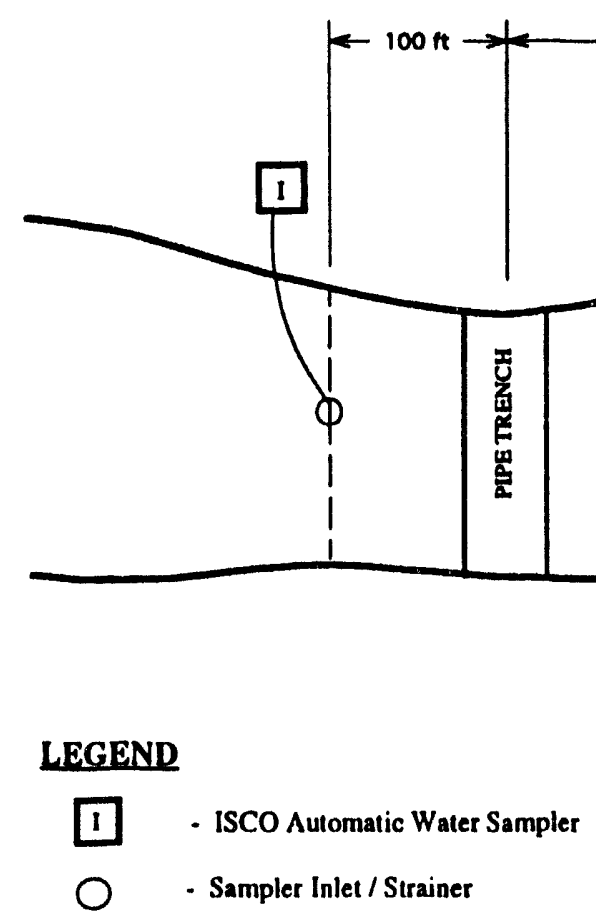

NOT TO SCALE

FIGURE B.2 Schematic Diagram Indicating Revised Sampler Locations 


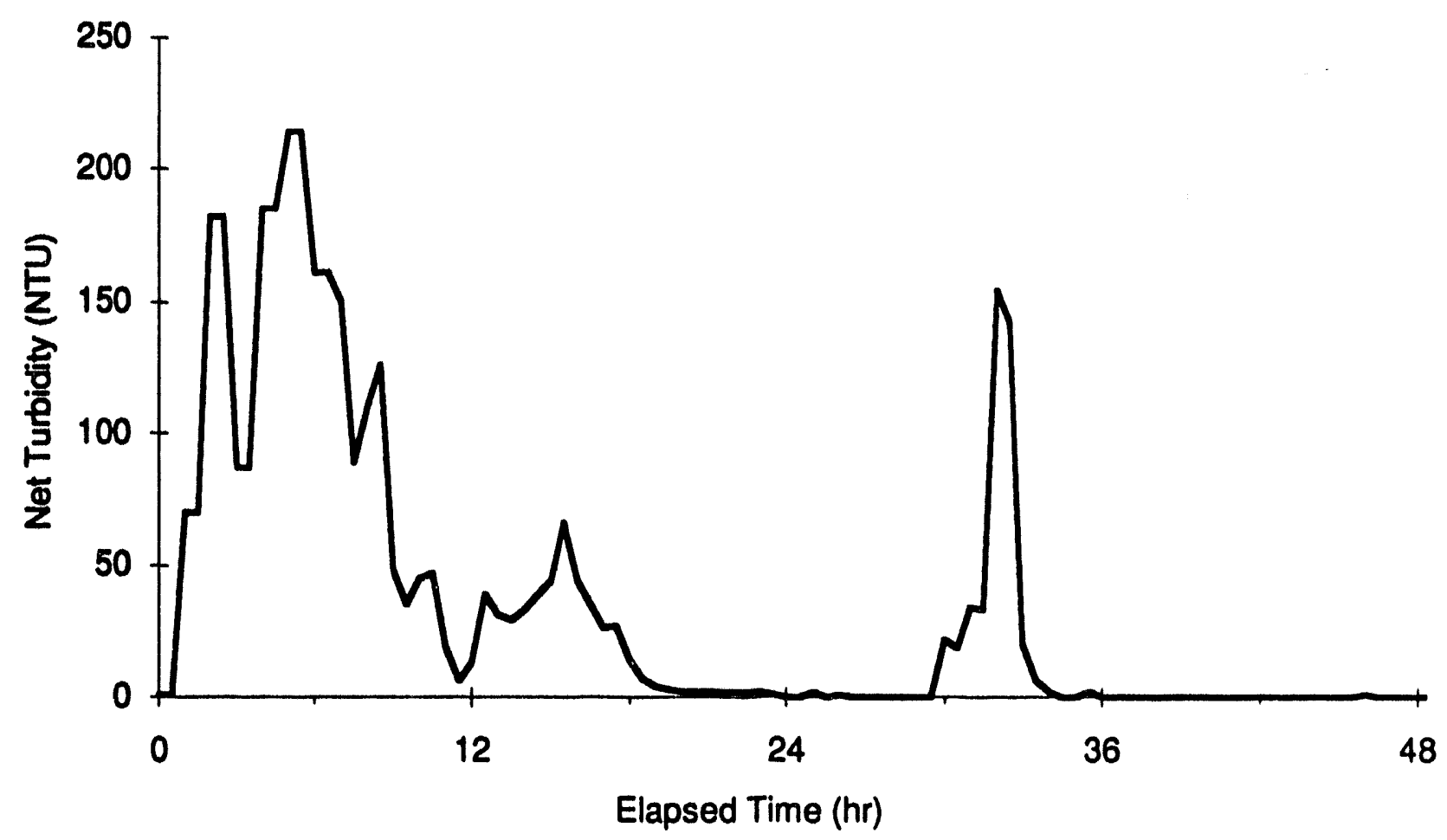

FIGURE B.3 Crossing \#8: Net Turbidity versus Time as Measured $600 \mathrm{ft}$ Downstream

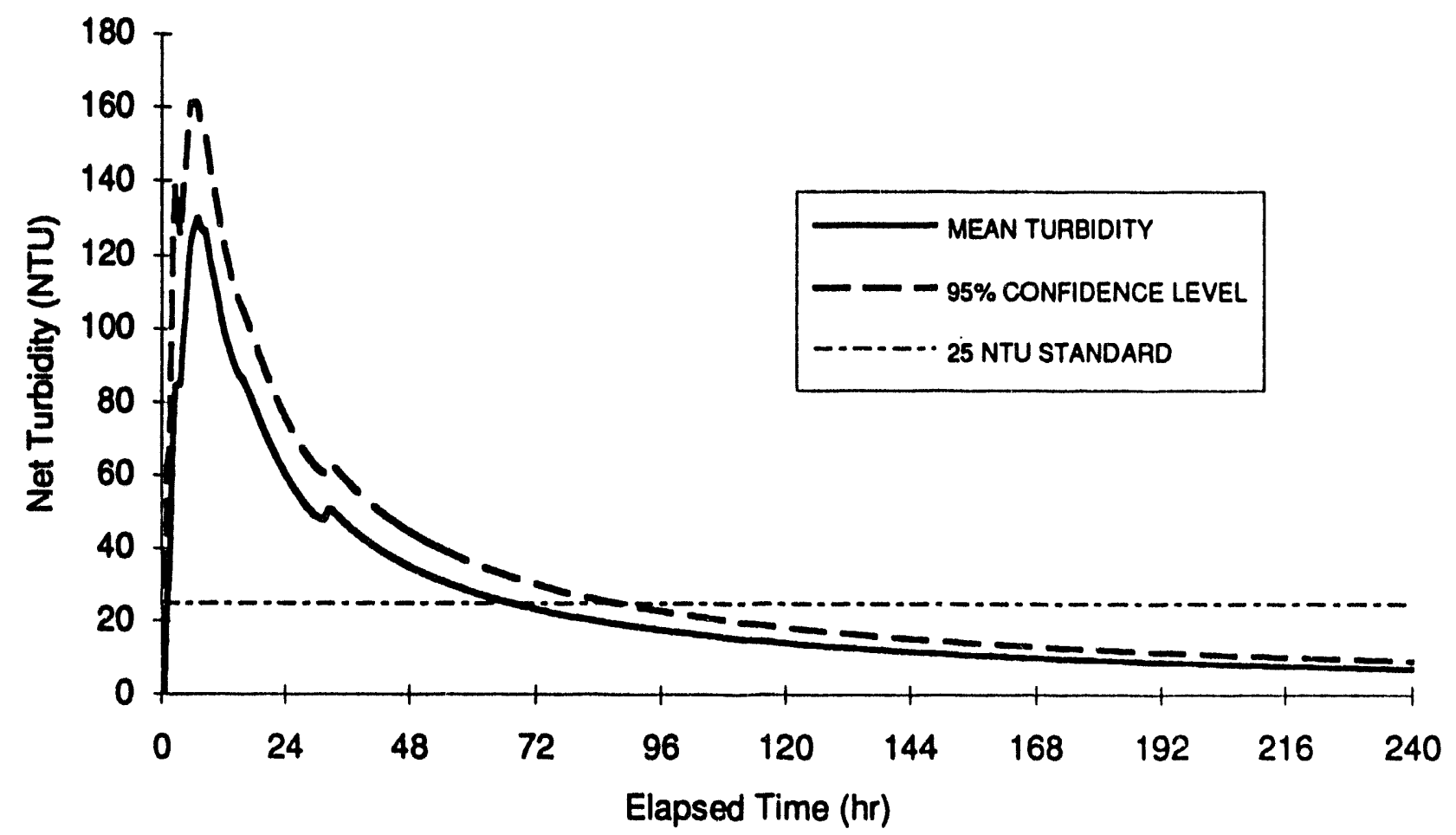

FIGURE B.4 Crossing \#8: Running Average of Net Turbidity versus Time as Measured $600 \mathrm{ft}$ Downstream 


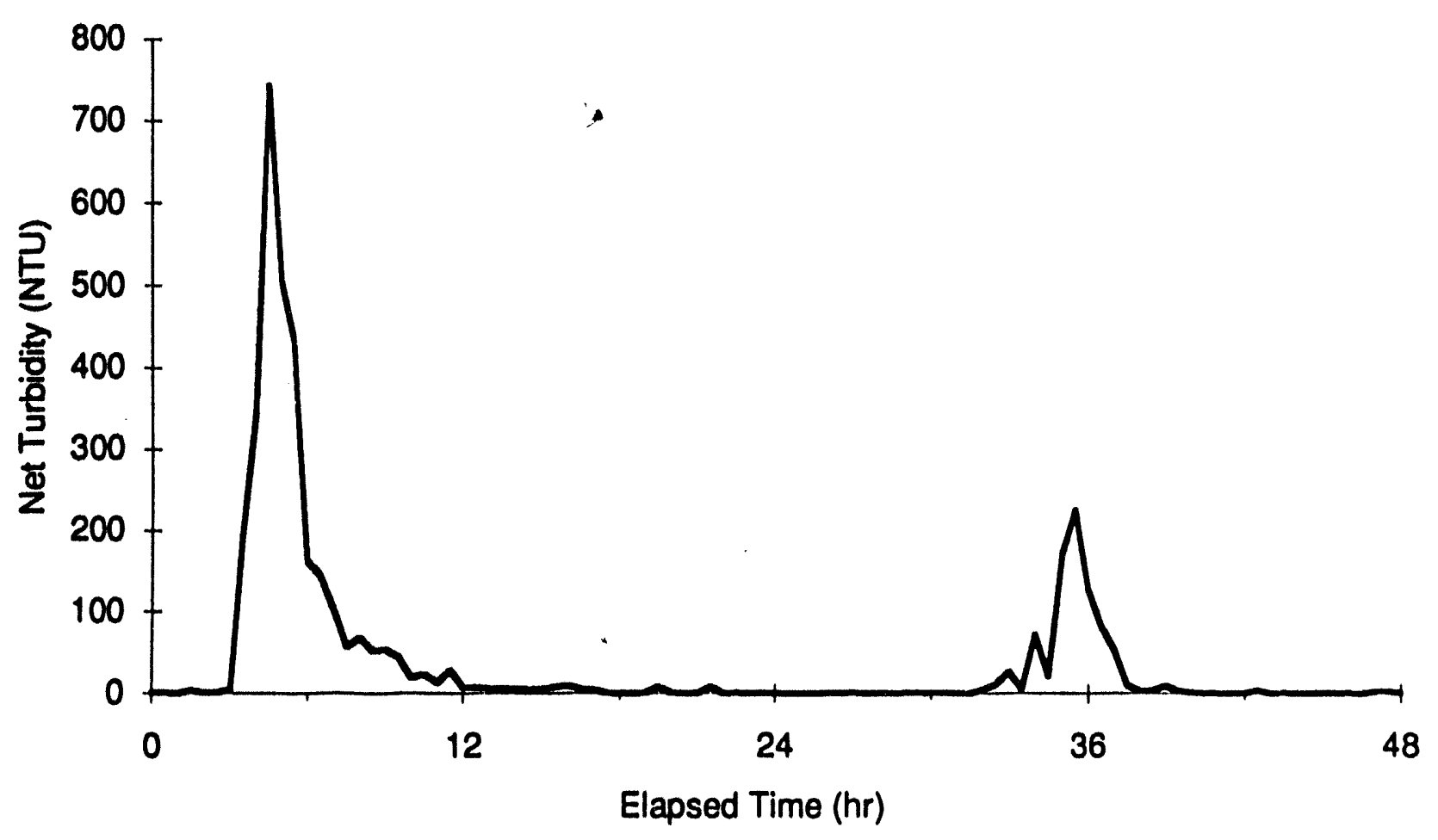

FIGURE B.5 Crossing \#6: Net Turbidity versus Time as Measured $600 \mathrm{ft}$ Downstream

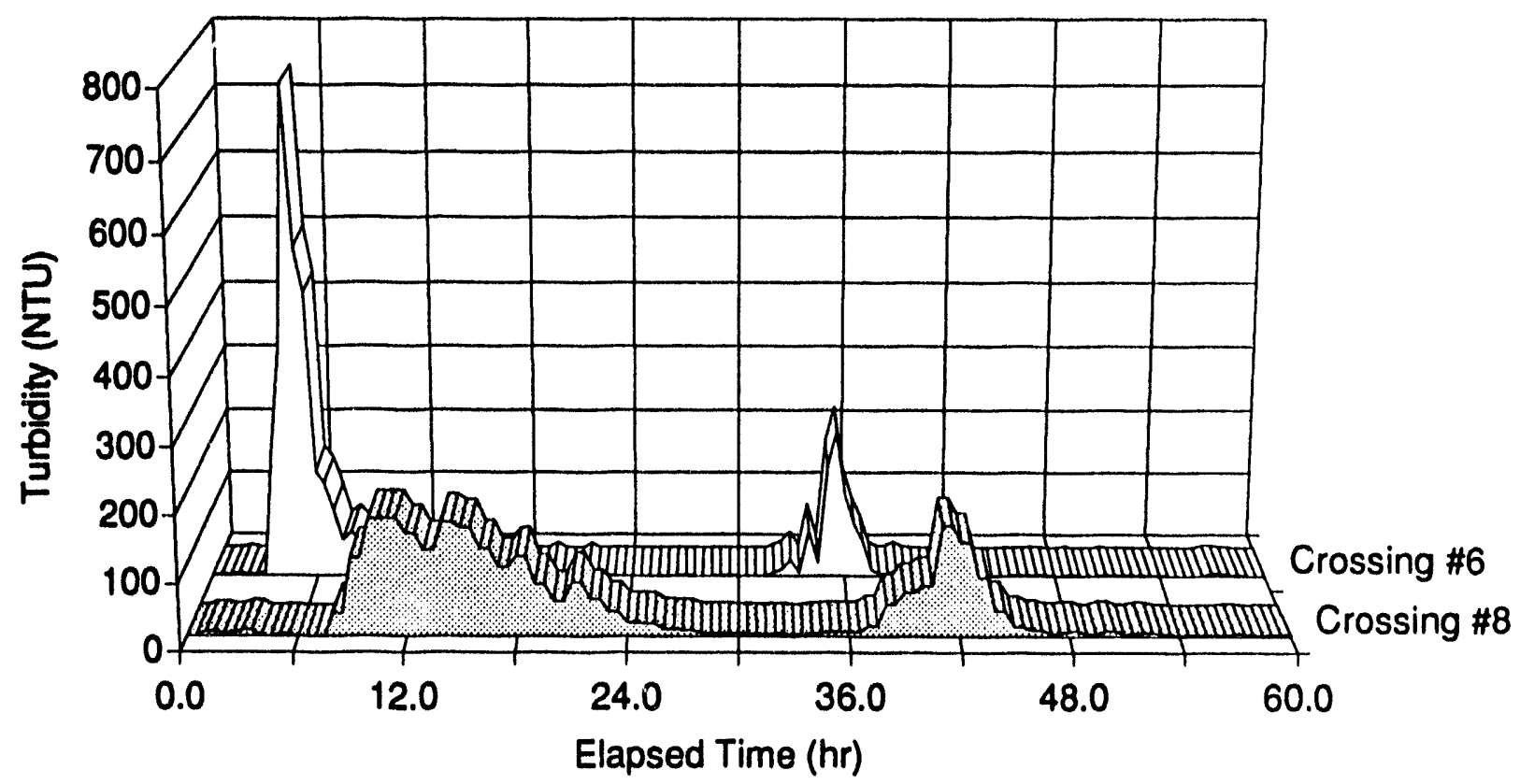

FIGURE B.6 Turbidity Generated by Crossing \#6 as Measured Downstream at the Crossing \#8 Sampling Location 


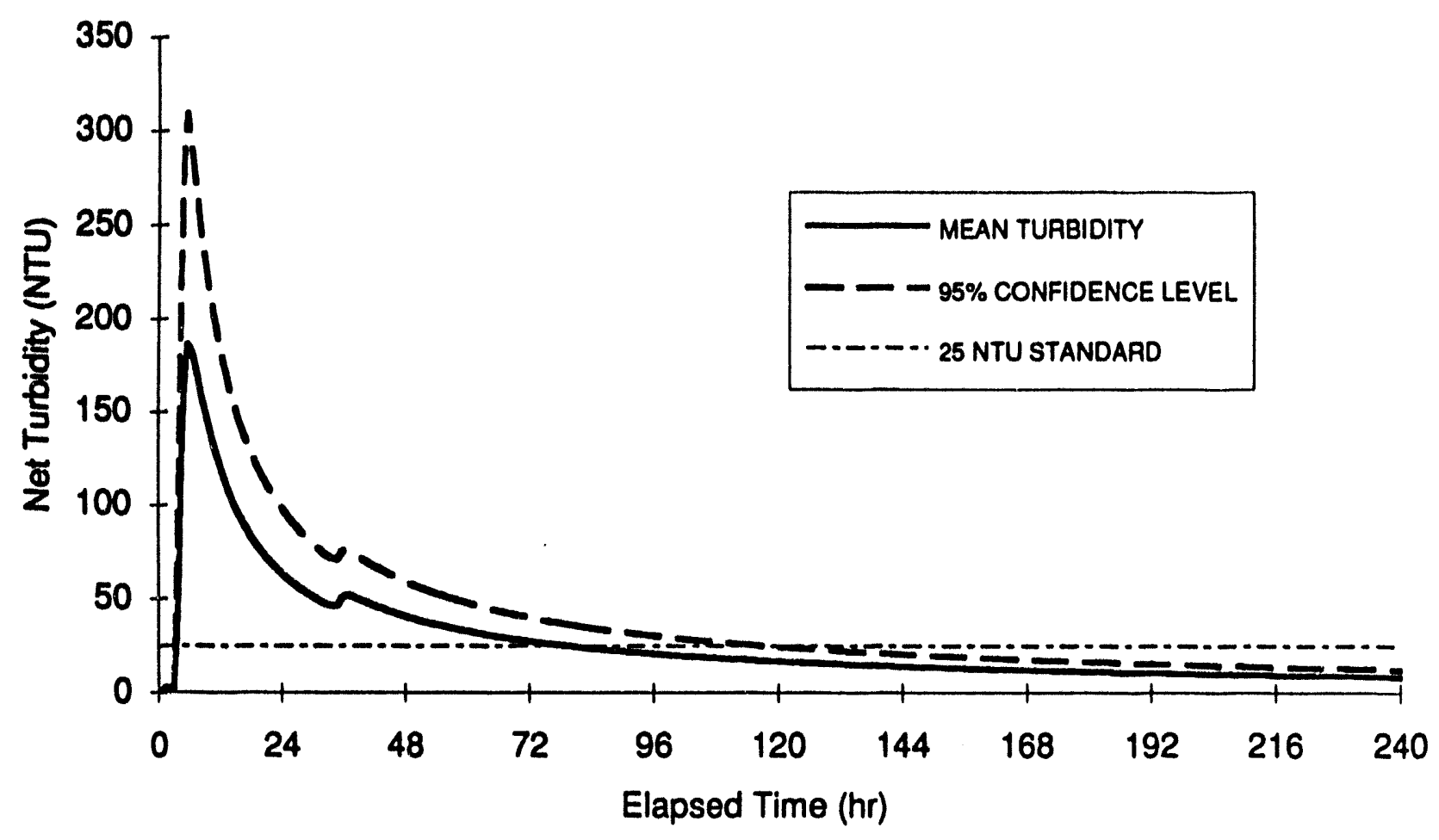

FIGURE B.7 Crossing \#6: Running Average of Net Turbidity versus Time as Measured $600 \mathrm{ft}$ Downstream

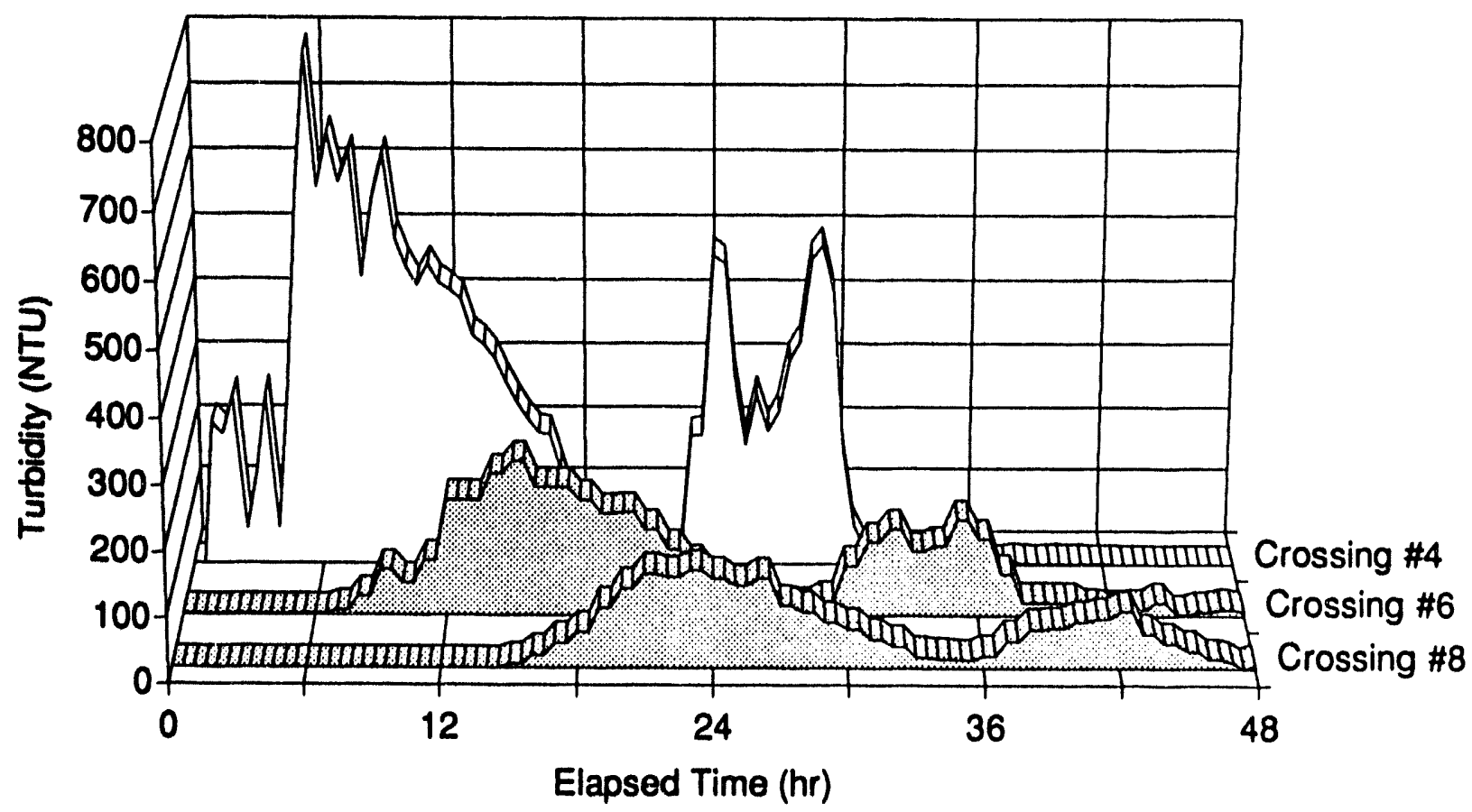

FIGURE B.8 Turbidity Generated by Crossing \#4 as Measured Downstream at Sampling Locations Crossings \#6 and \#8 


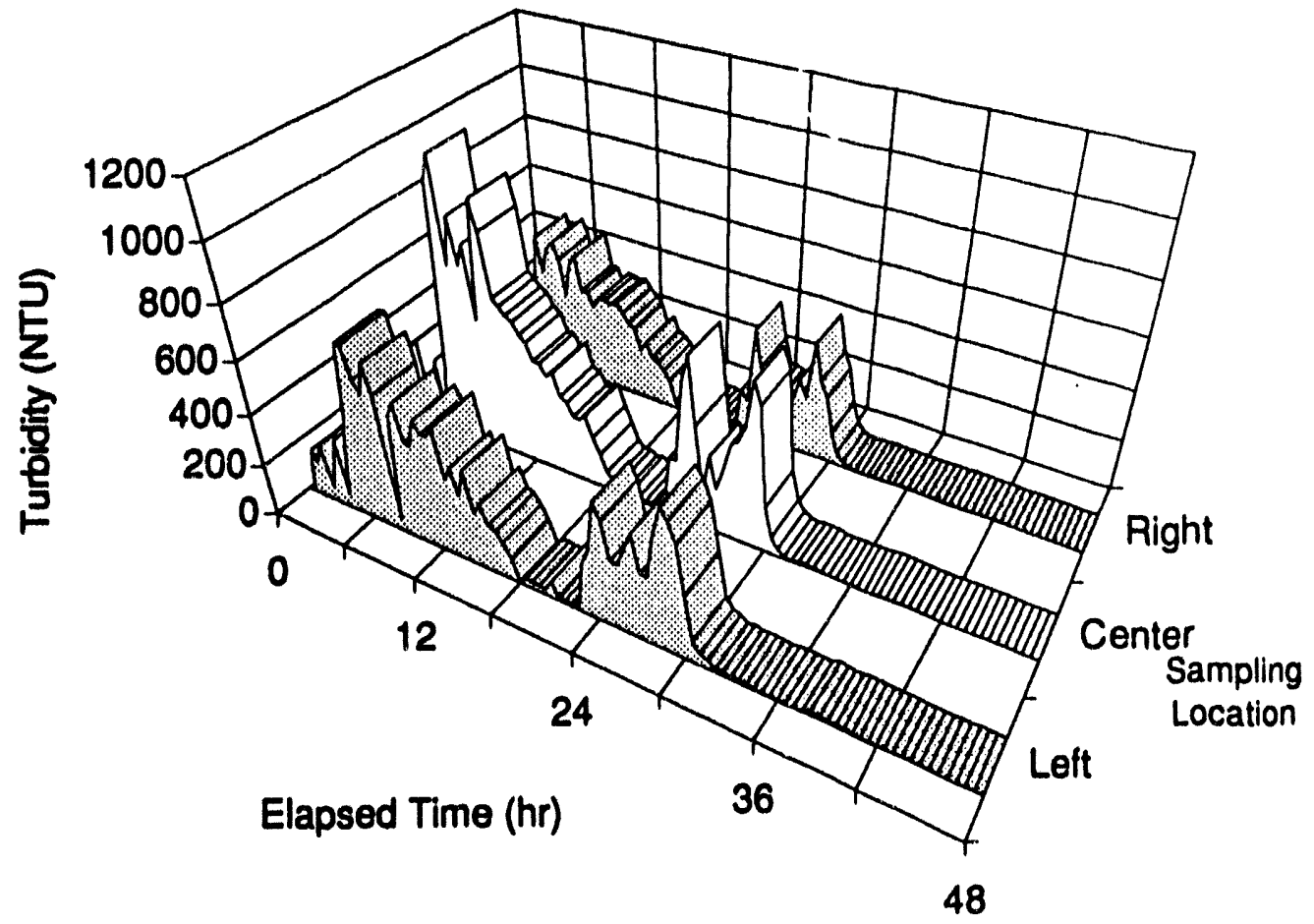

FIGURE B.9 Crossing \#4: Net Turbidity versus Time as Measured by Three Samplers $600 \mathrm{ft}$ Downstream

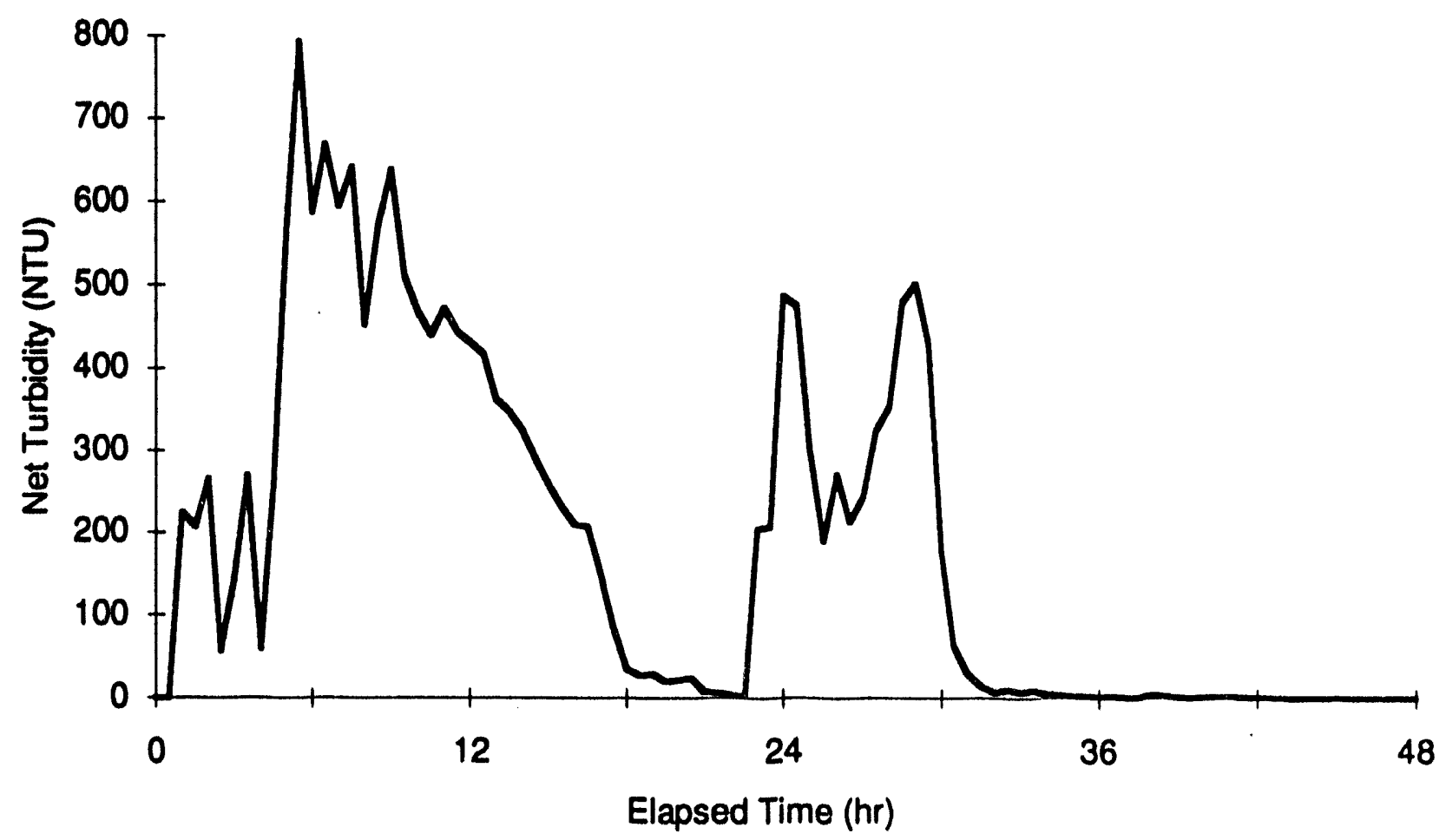

FIGURE B.10 Crossing \#4: Flow-Weighted Average of Net Turbidity Measured by Three Samplers $600 \mathrm{ft}$ Downstream versus Time 


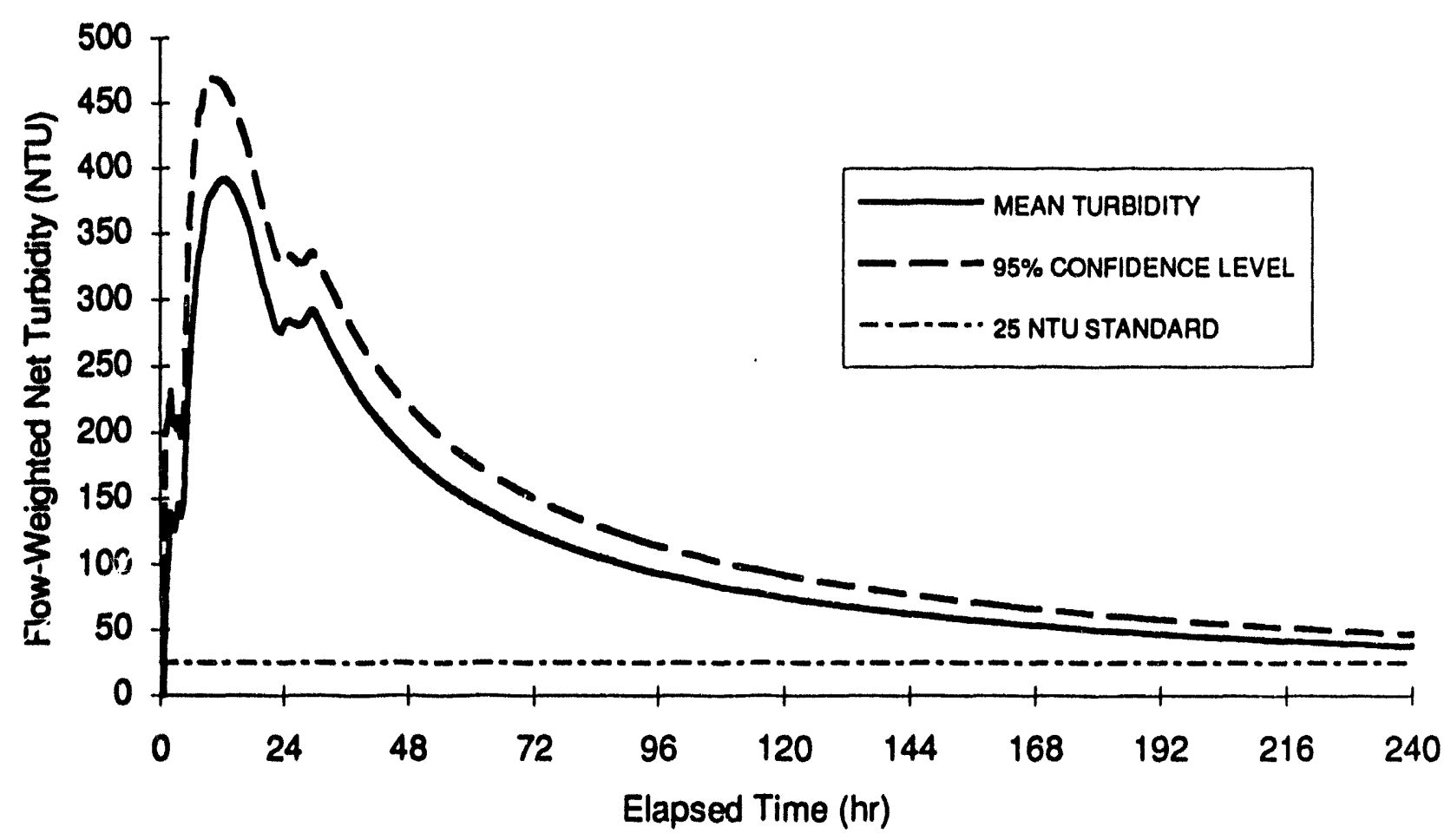

FIGURE B.11 Crossing \#4: Running Average of Flow-Weighted Net Turbidity as Measured $600 \mathrm{ft}$ Downstream versus Time

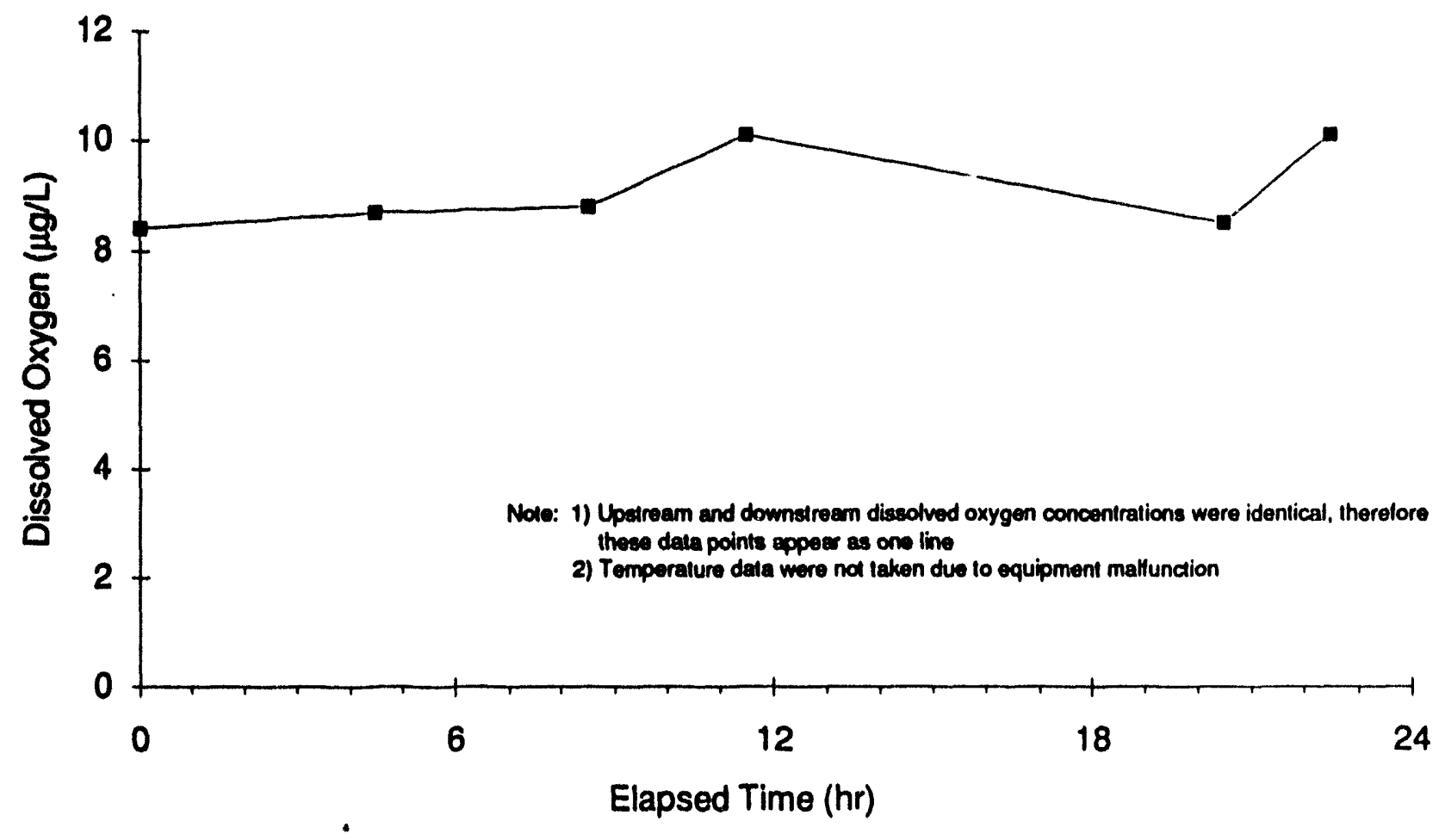

FIGURE B.12 Crossing \#4: Dissolved Oxygen Measured Upstream and $600 \mathrm{ft}$ Downstream versus Time 


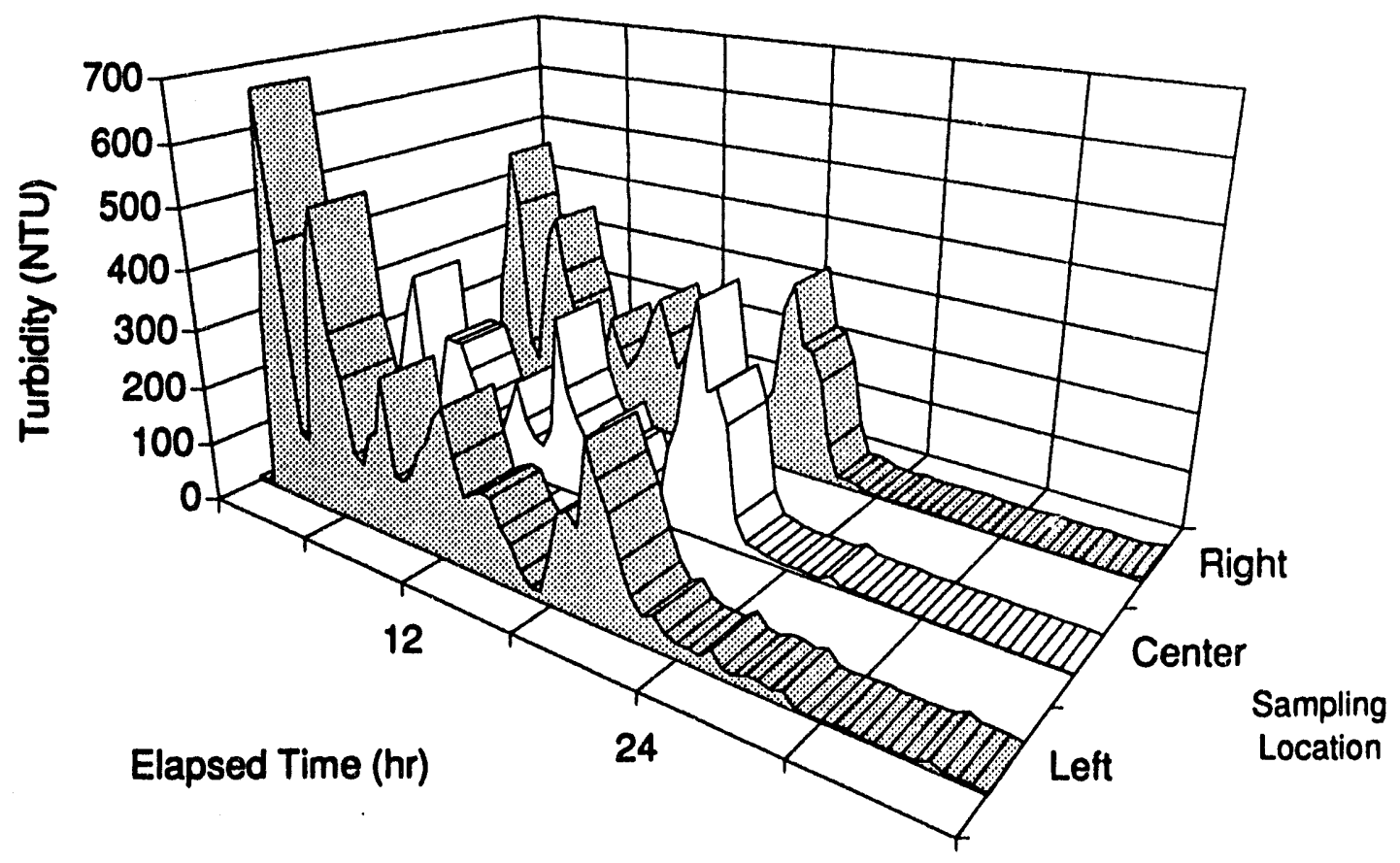

36

FIGURE B.13 Crossing \#5: Net Turbidity versus Time as Measured by Three Samplers $600 \mathrm{ft}$ Downstream

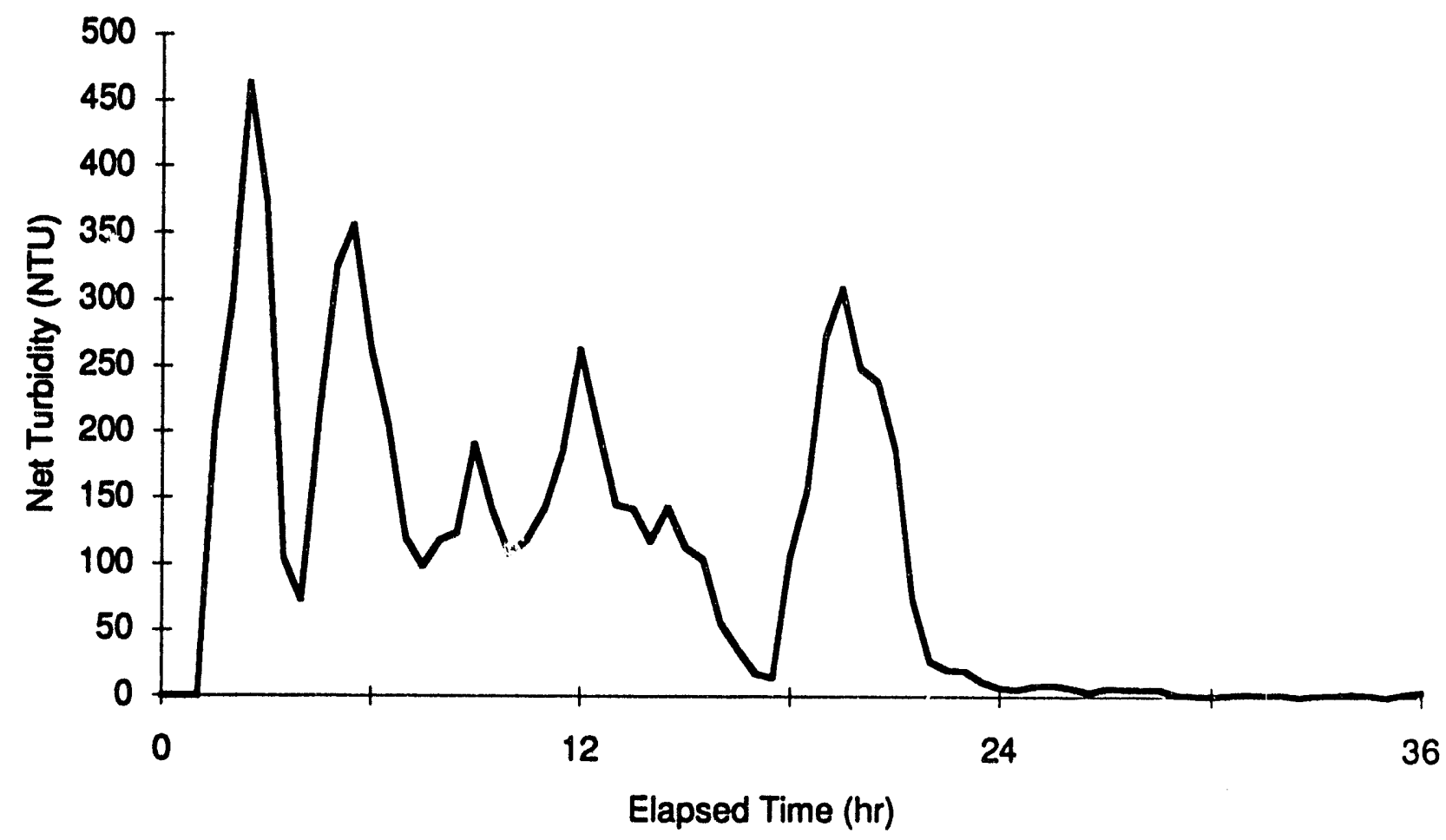

FIGURE B.14 Crossing \#5: Flow-Weighted Average of Net Turbidity Measured by Three Samplers $600 \mathrm{ft}$ Downstream versus Time 


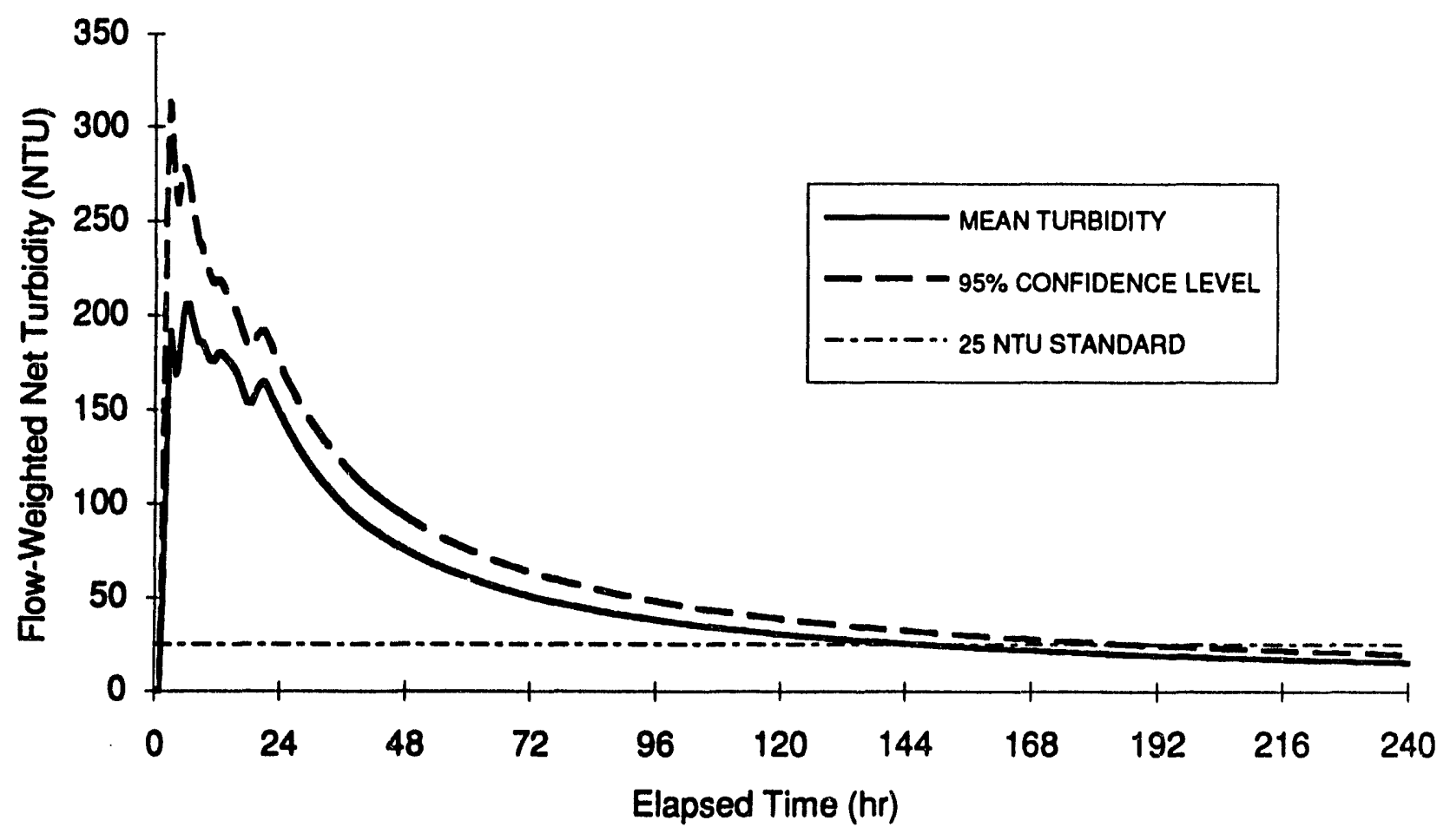

FIGURE B.15 Crossing \#5: Running Average of Flow-Weighted Net Turbidity as Measured $600 \mathrm{ft}$ Downstream versus Time

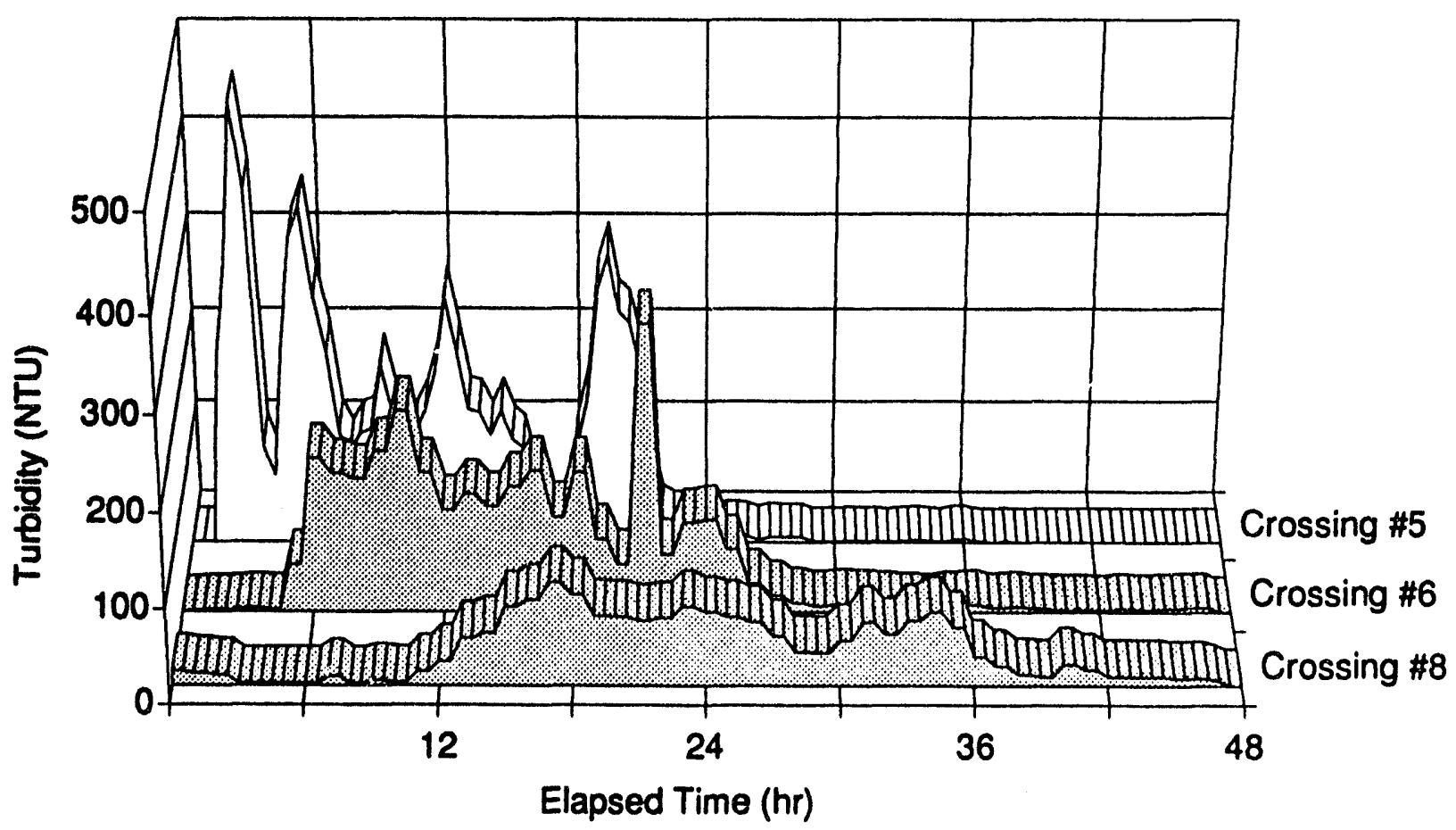

FIGURE B.16 Turbidity Generated by Crossing \#5 as Measured Downstream at Sampling Locations at Crossings \#6 and \#8 

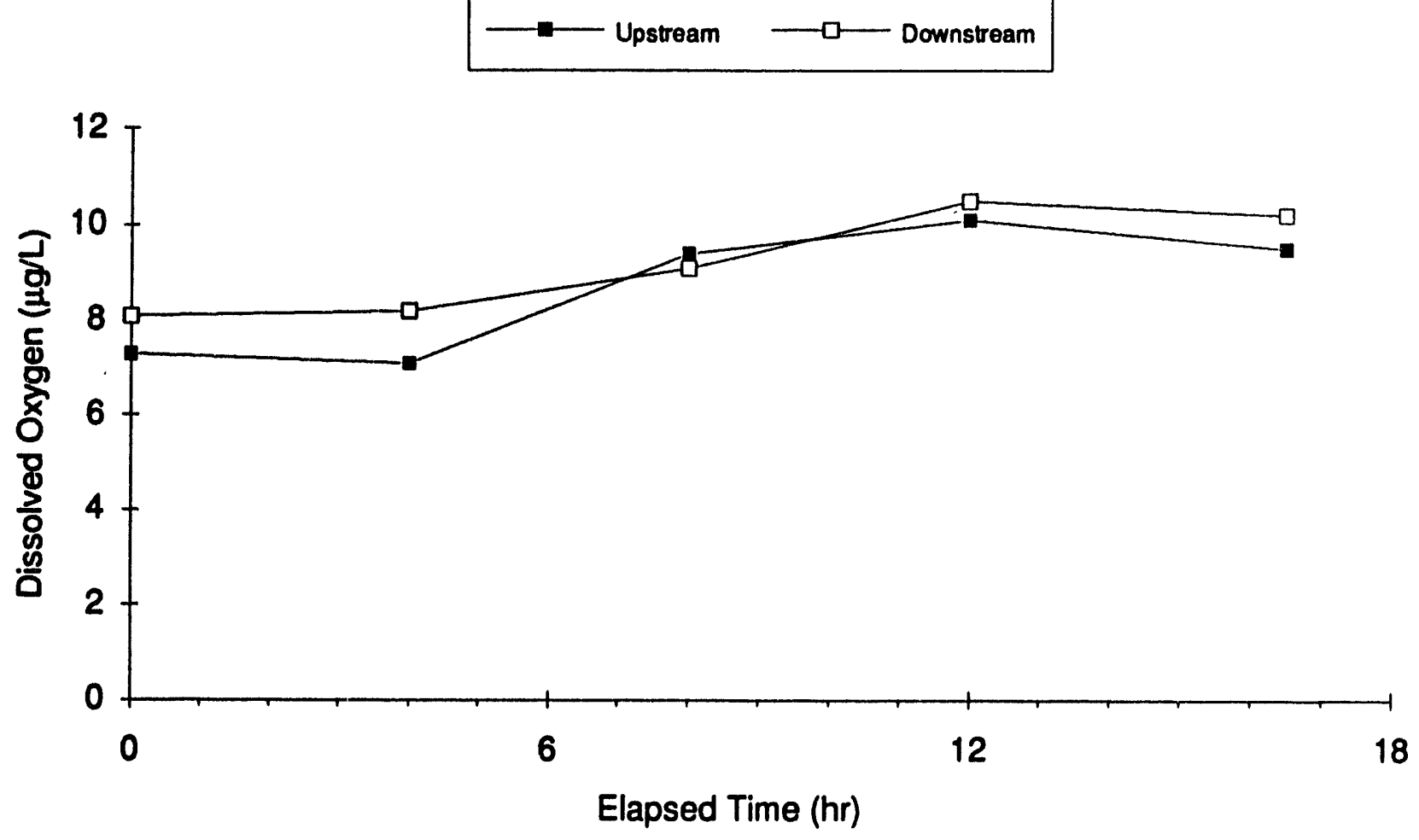

FIGURE B.17 Crossing \#5: Dissolved Oxygen Measured Upstream and $600 \mathrm{ft}$ Downstream versus Time
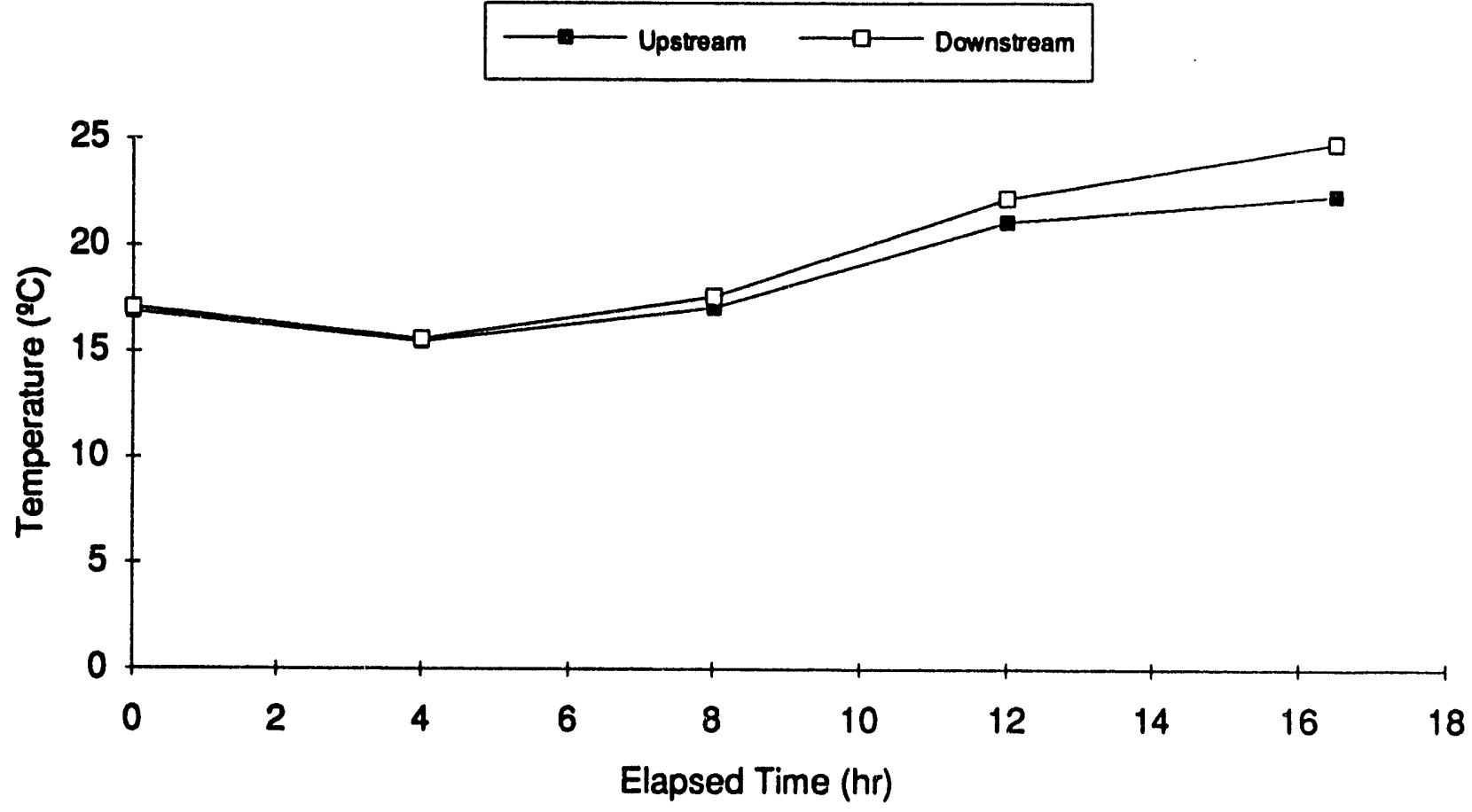

FIGURE B.18 Crossing \#5: Temperature Measured Upstream and $600 \mathrm{ft}$ Downstream versus Time 


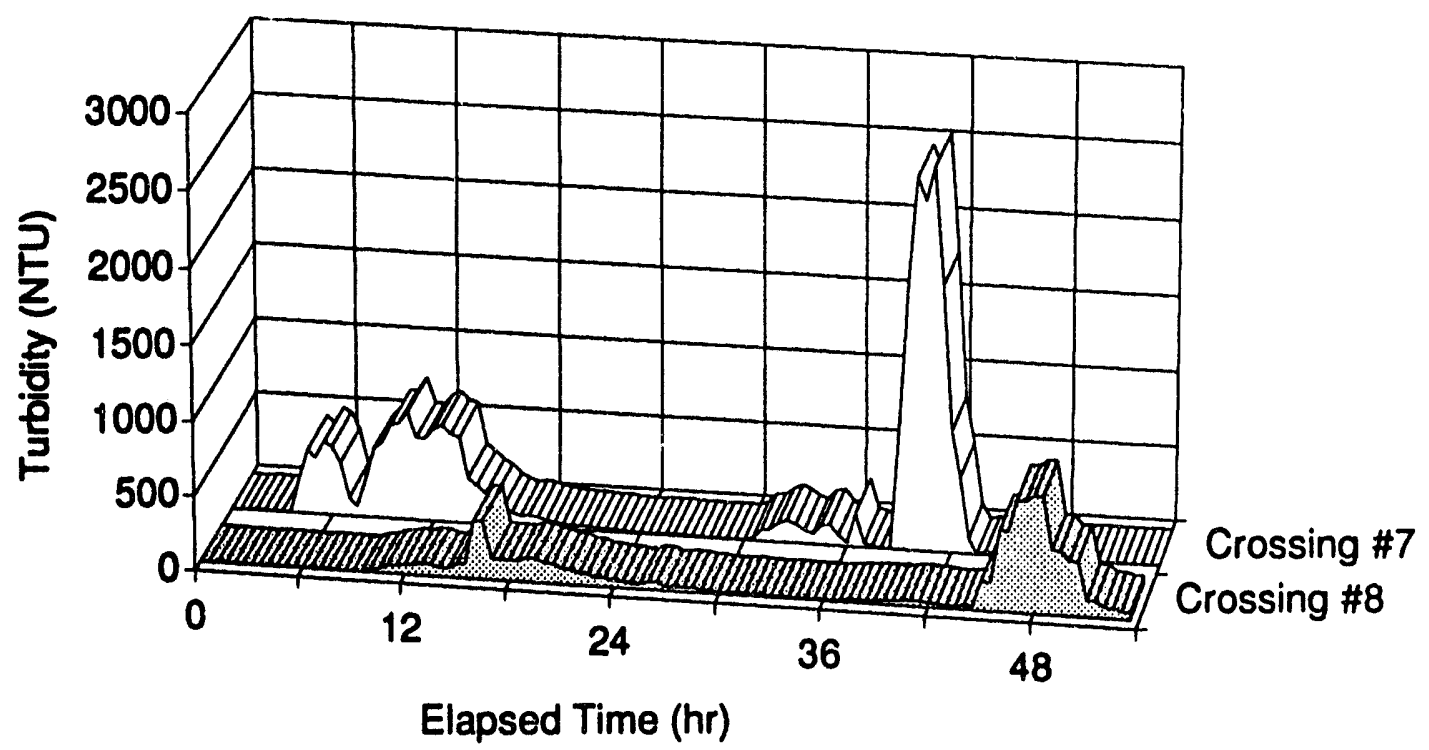

FIGURE B.19 Turbidity Generated by Crossing \#7 as Measured Downstream at the Crossing \#8 Sampling Location

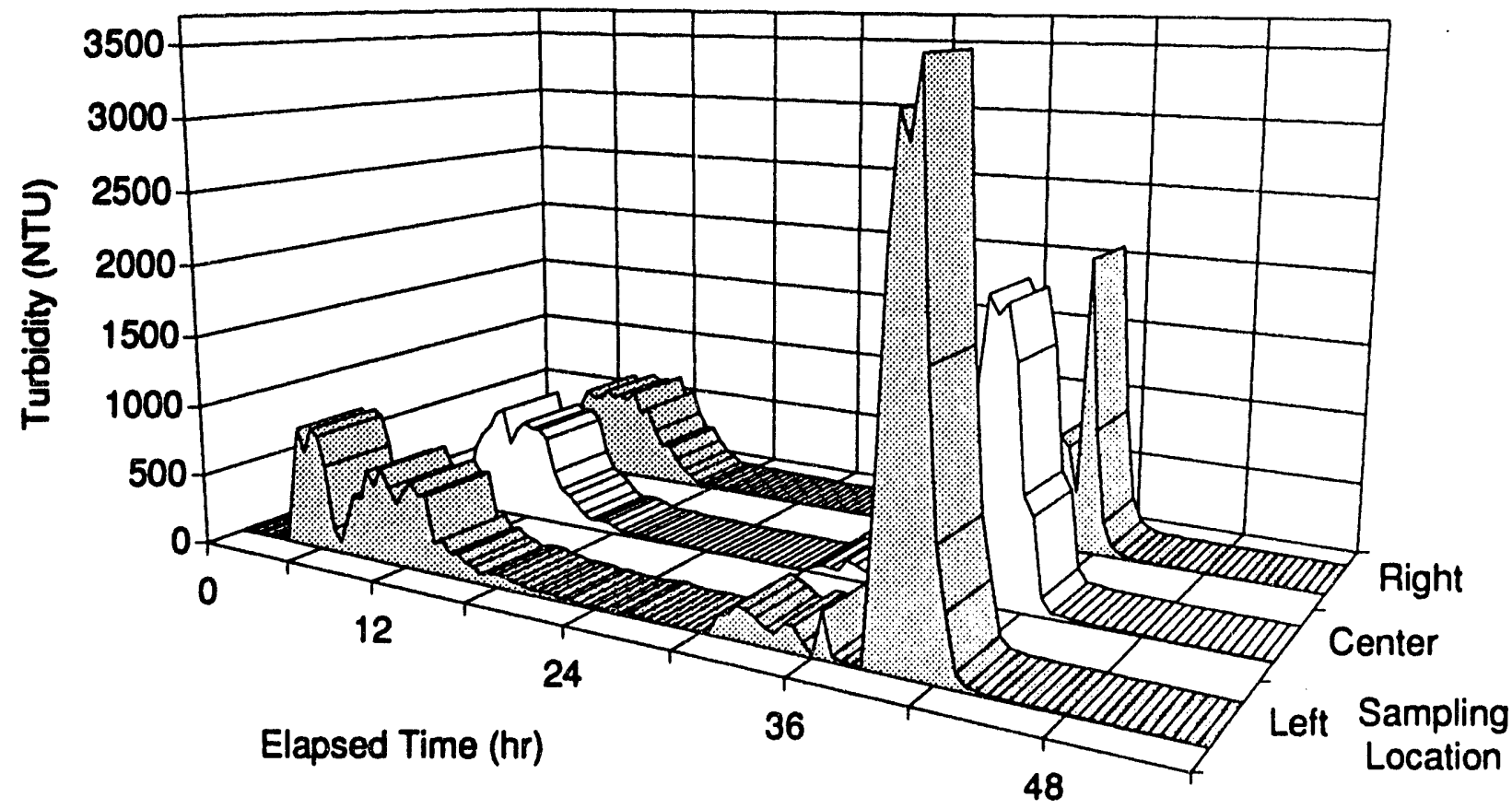

FIGURE B.20 Crossing \#7: Net Turbidity versus Time as Measured by Three Samplers $600 \mathrm{ft}$ Downstream 


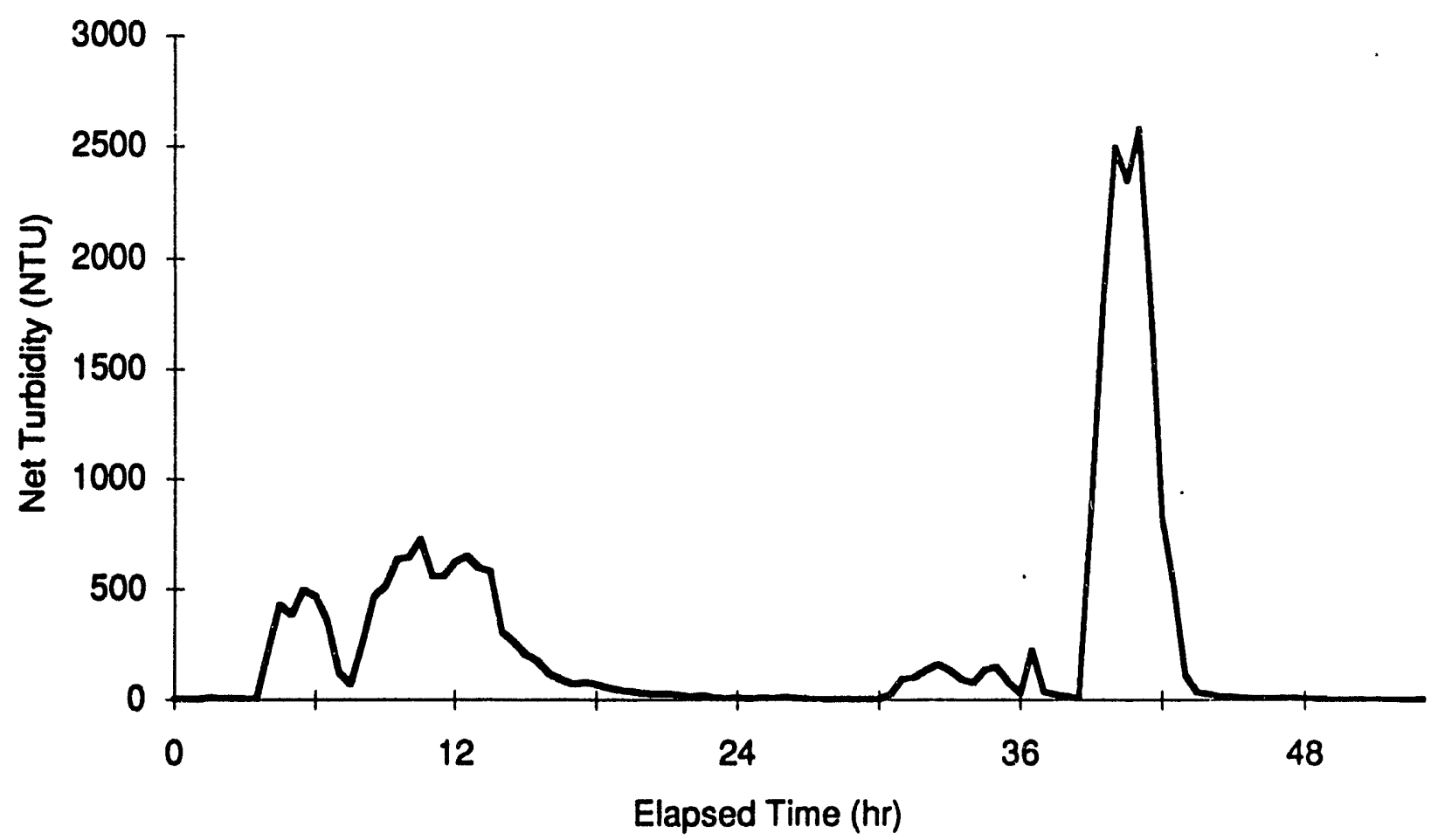

FIGURE B.21 Crossing \#7: Flow-Weighted Average of Net Turbidity Measured by Three Samplers $600 \mathrm{ft}$ Downstream versus Time

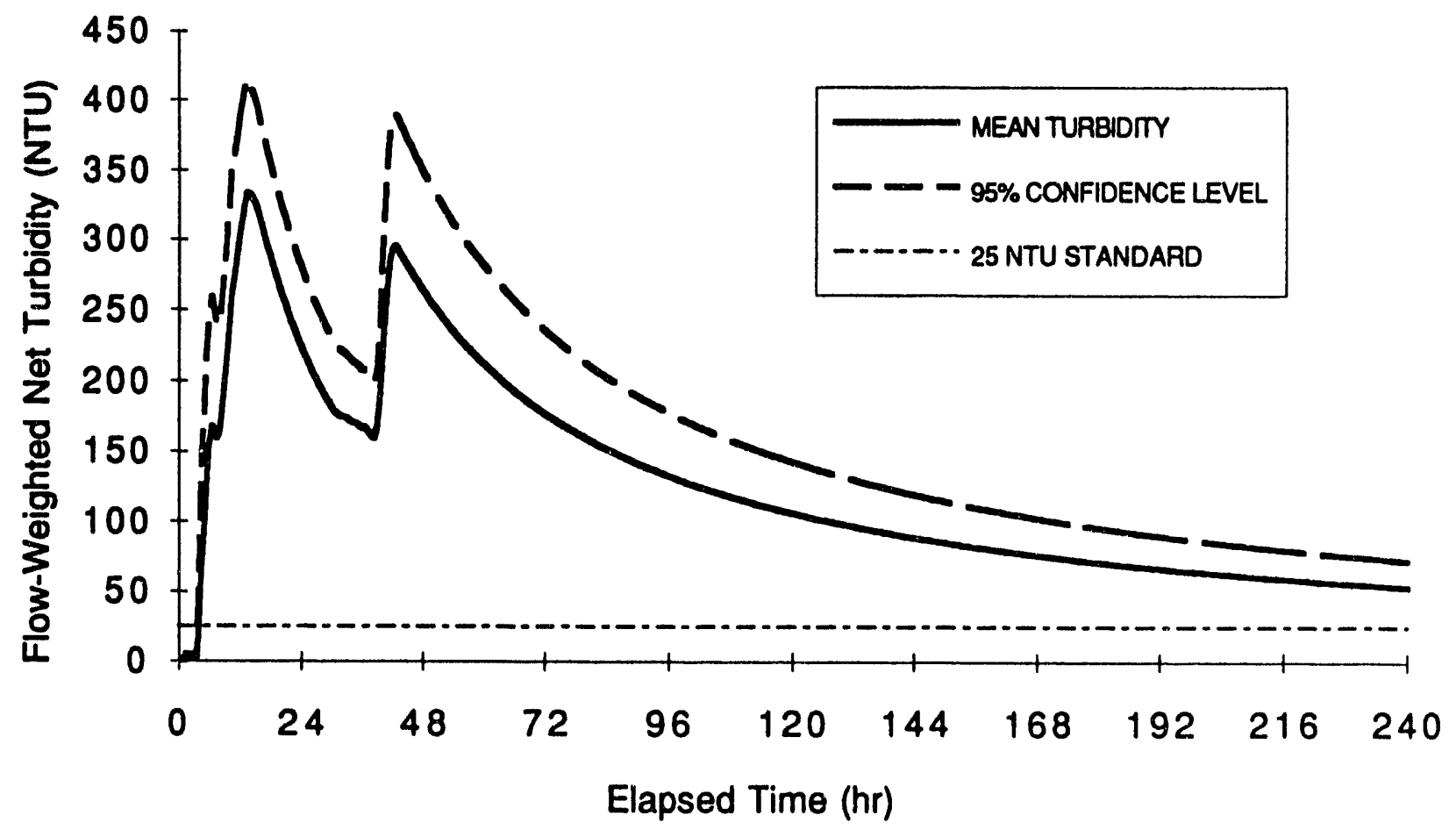

FIGURE B.22 Crossing \#7: Running Average of Flow-Weighted Net Turbidity as Measured $600 \mathrm{ft}$ Downstream versus Time 

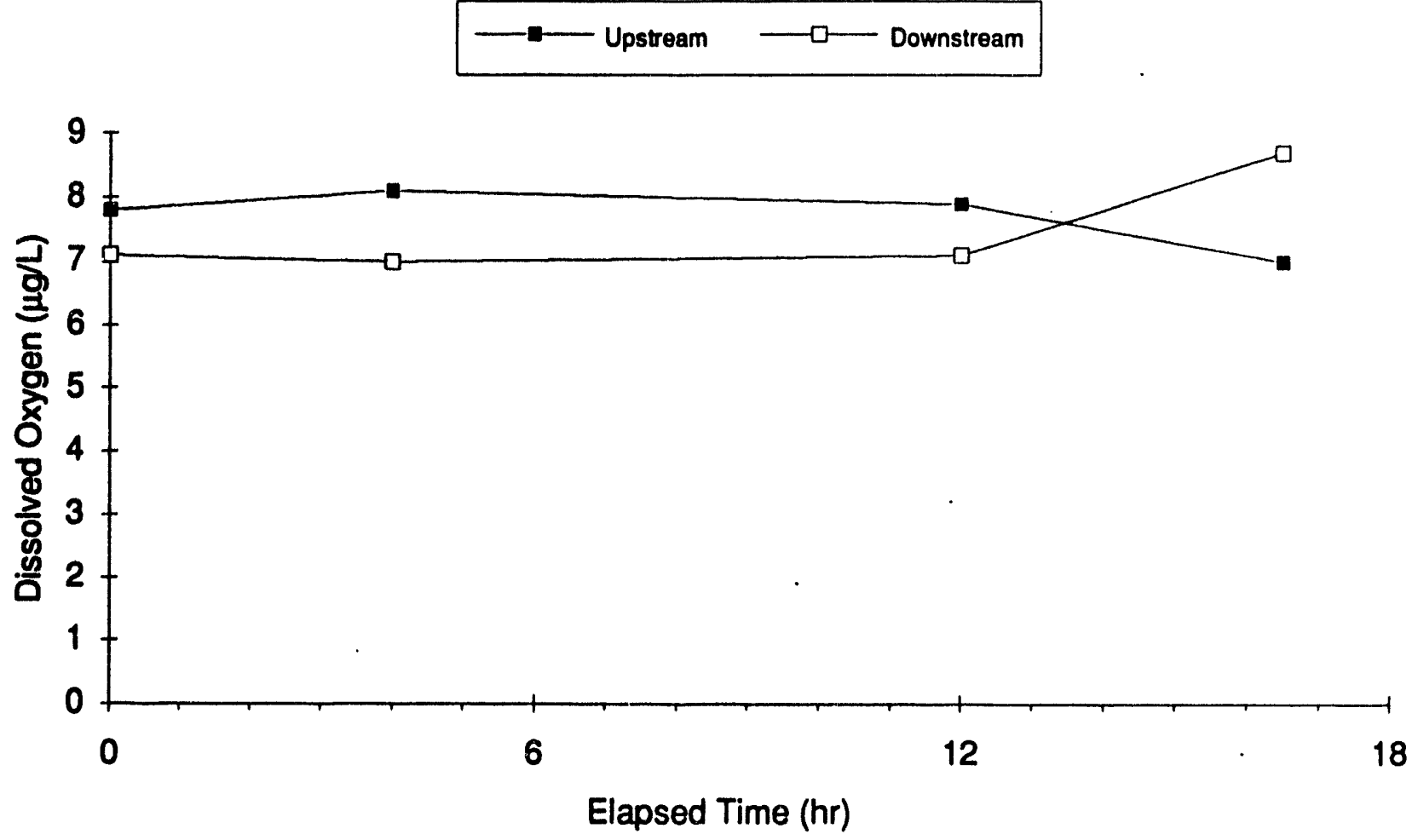

FIGURE B.23 Crossing \#7: Dissolved Oxygen Measured Upstream and $600 \mathrm{ft}$ Downstream versus Timn
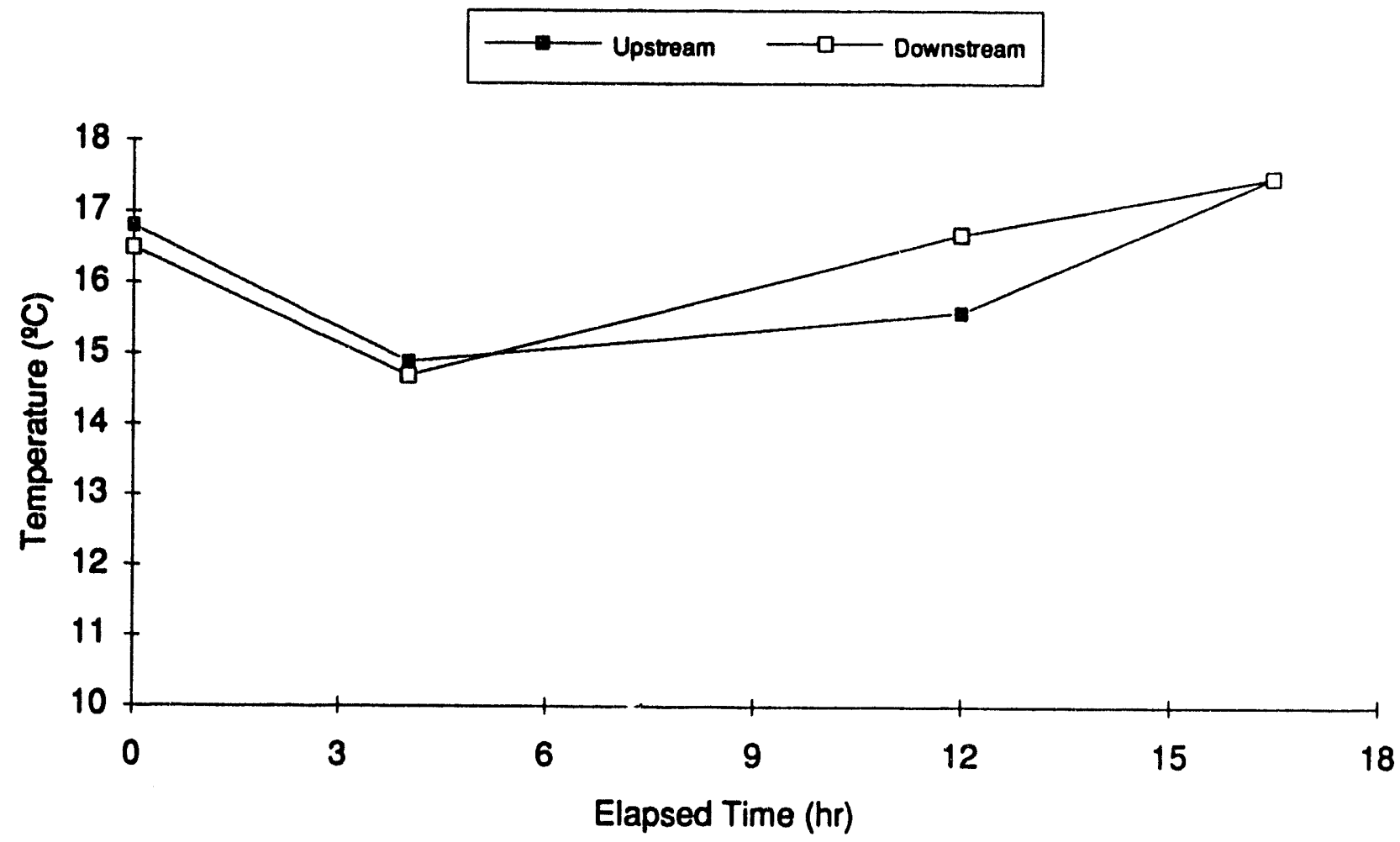

FIGURE B.24 Crossing \#7: Temperature Measured Upstream and $600 \mathrm{ft}$ Downstream versus Time 


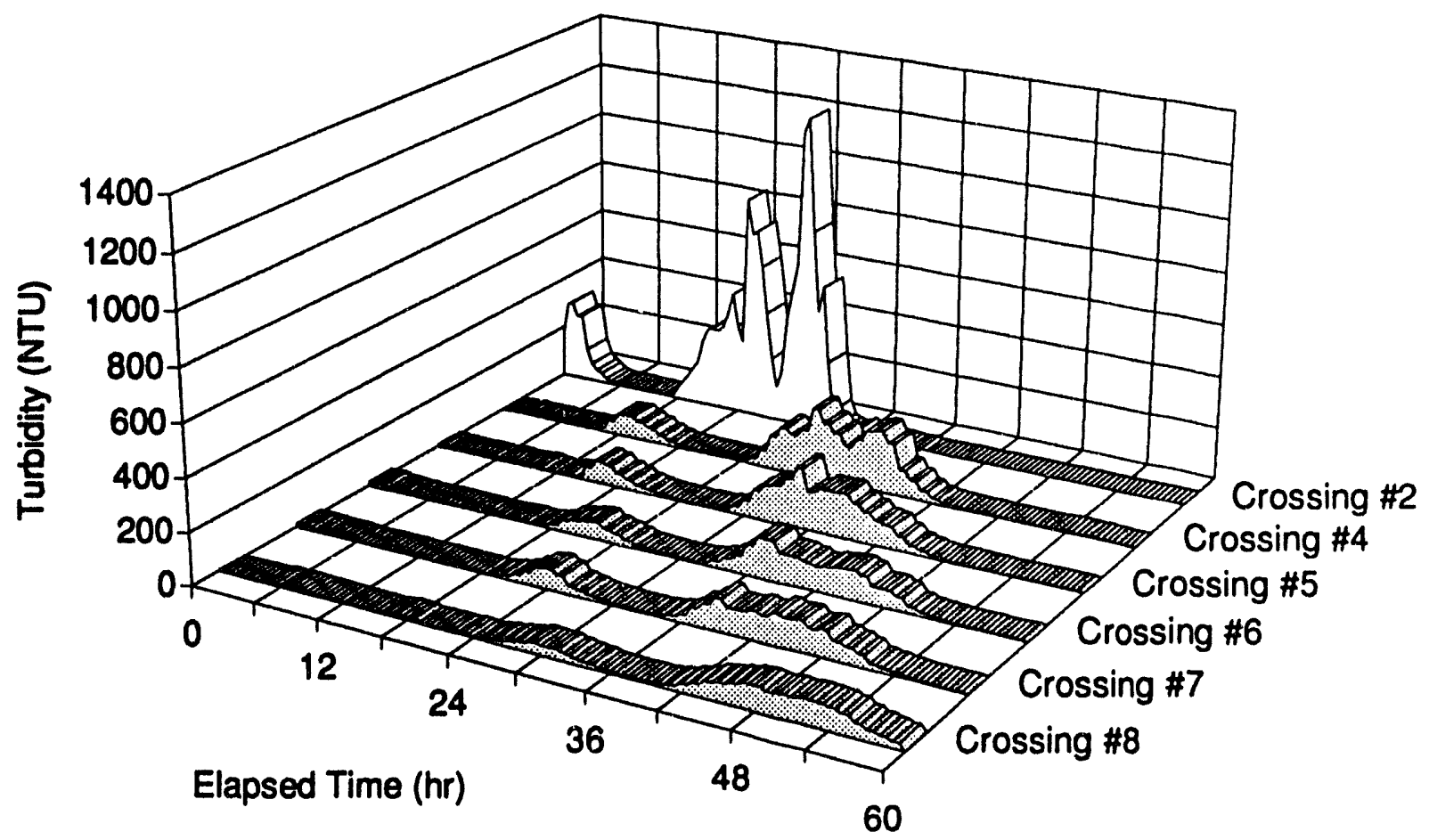

FIGURE B.25 Turbidity Generated by Crossing \#2 as Measured Downstream at the Sampling Locations at Crossings \#4, \#5, \#6, \#7, and \#8

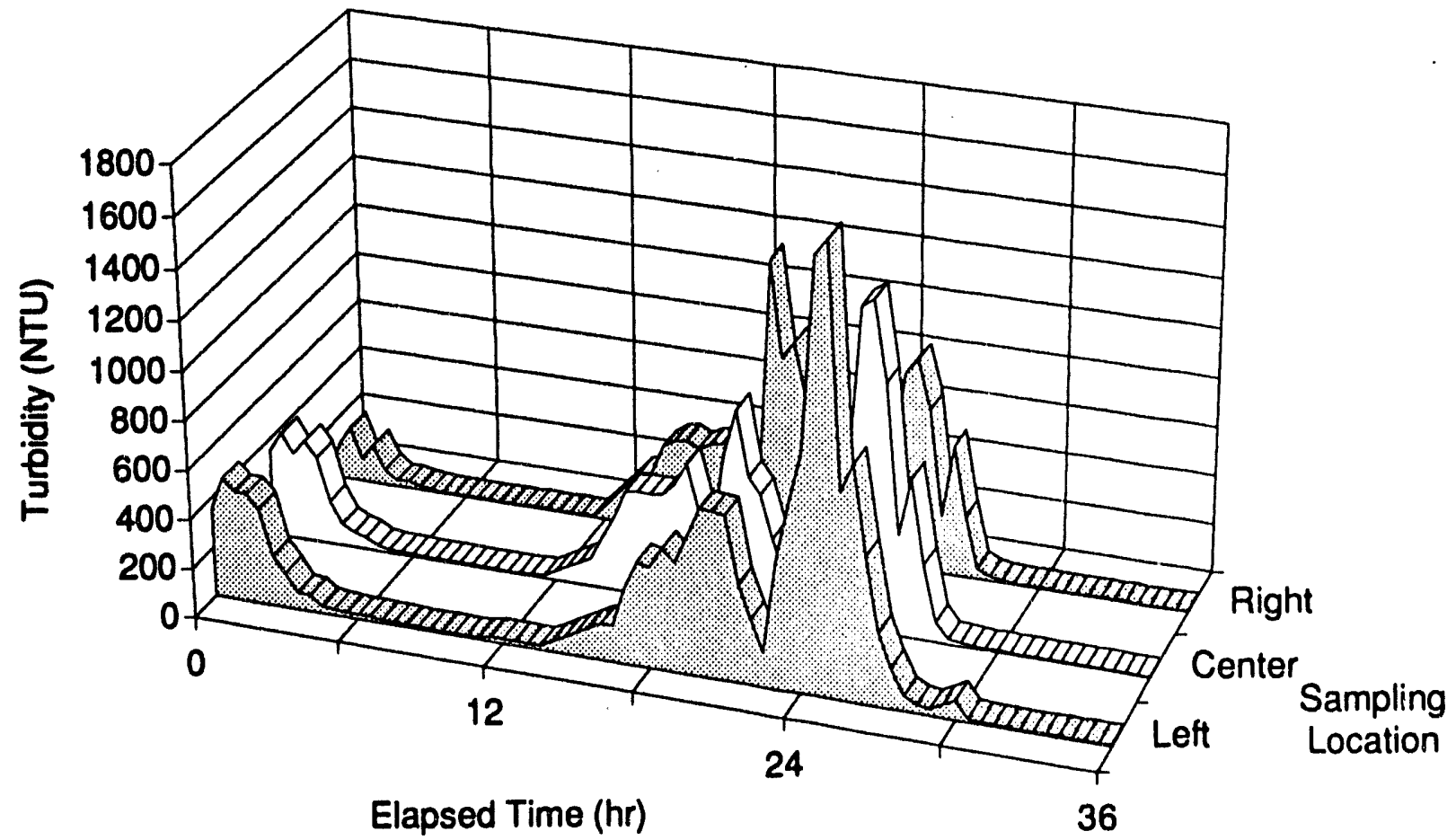

FIGURE B.26 Crossing \#2: Net Turbidity versus Time as Measured by Three Samplers $600 \mathrm{ft}$ Downstream 


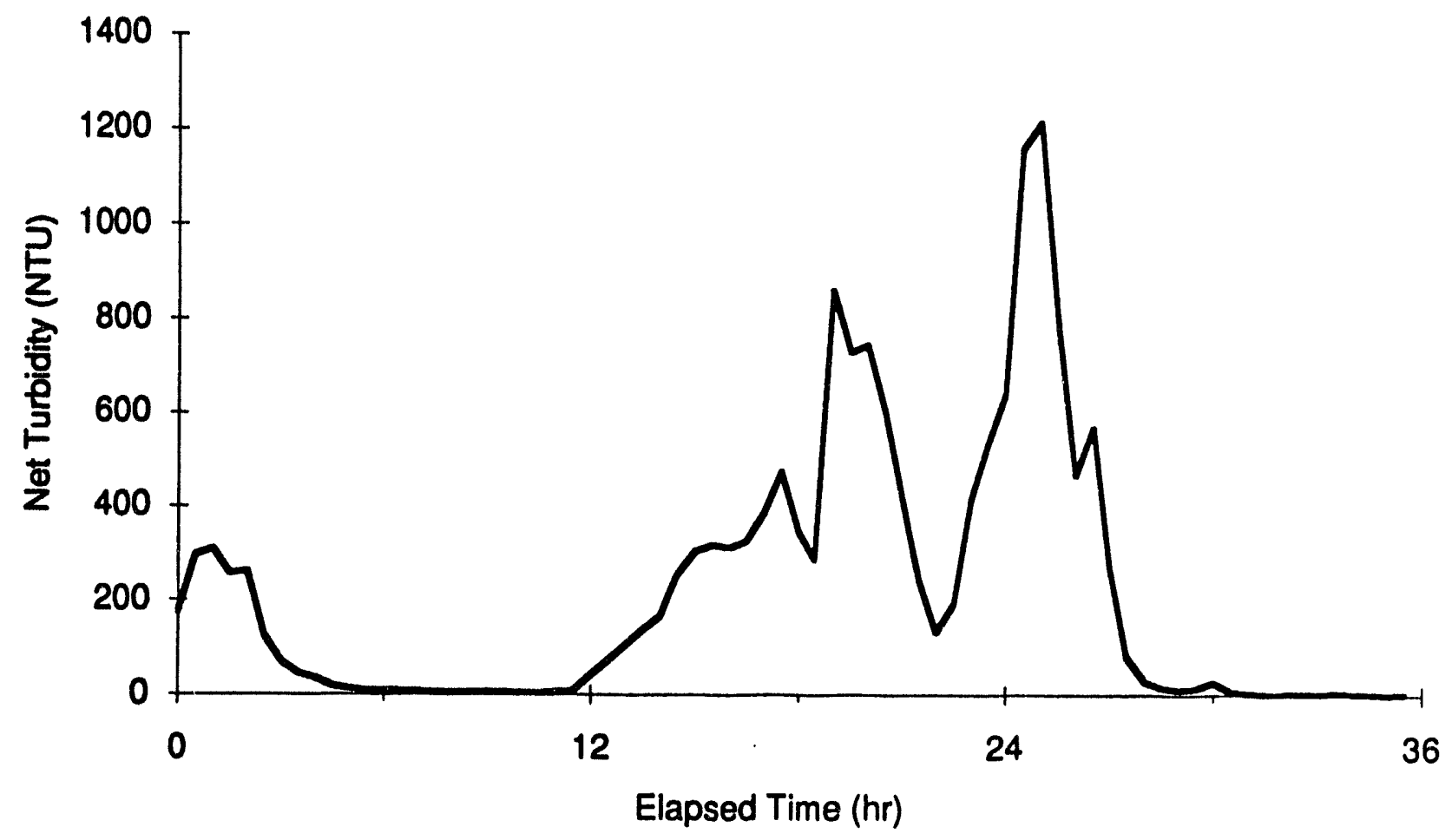

FIGURE B.27 Crossing \#2: Flow-Weighted Average of Net Turbidity Measured by Three Samplers $600 \mathrm{ft}$ Downstream versus Time

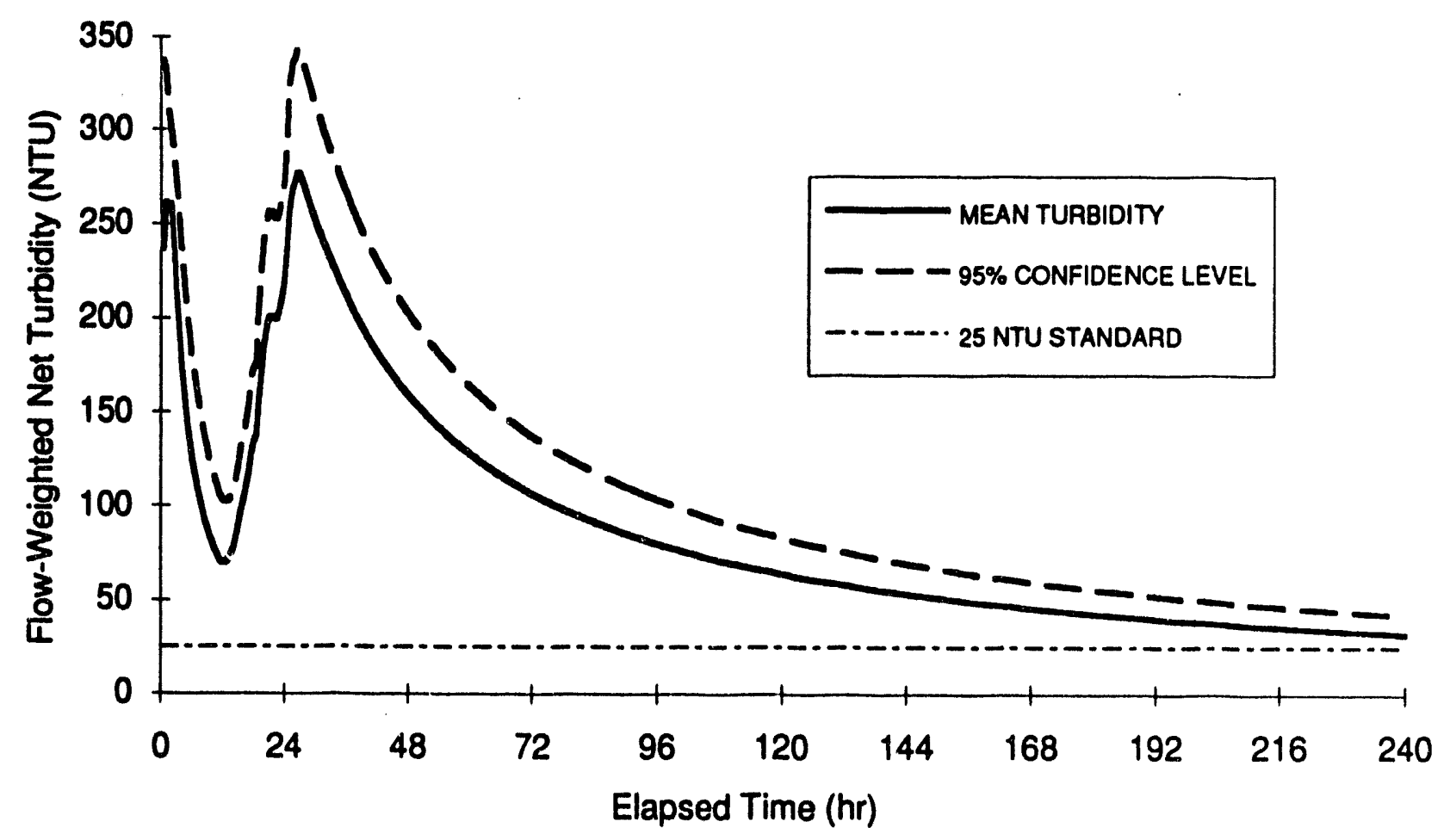

FIGURE B.28 Crossing \#2: Running Average of Flow-Weighted Net Turbidity as Measured $600 \mathrm{ft}$ Downstream versus Time 

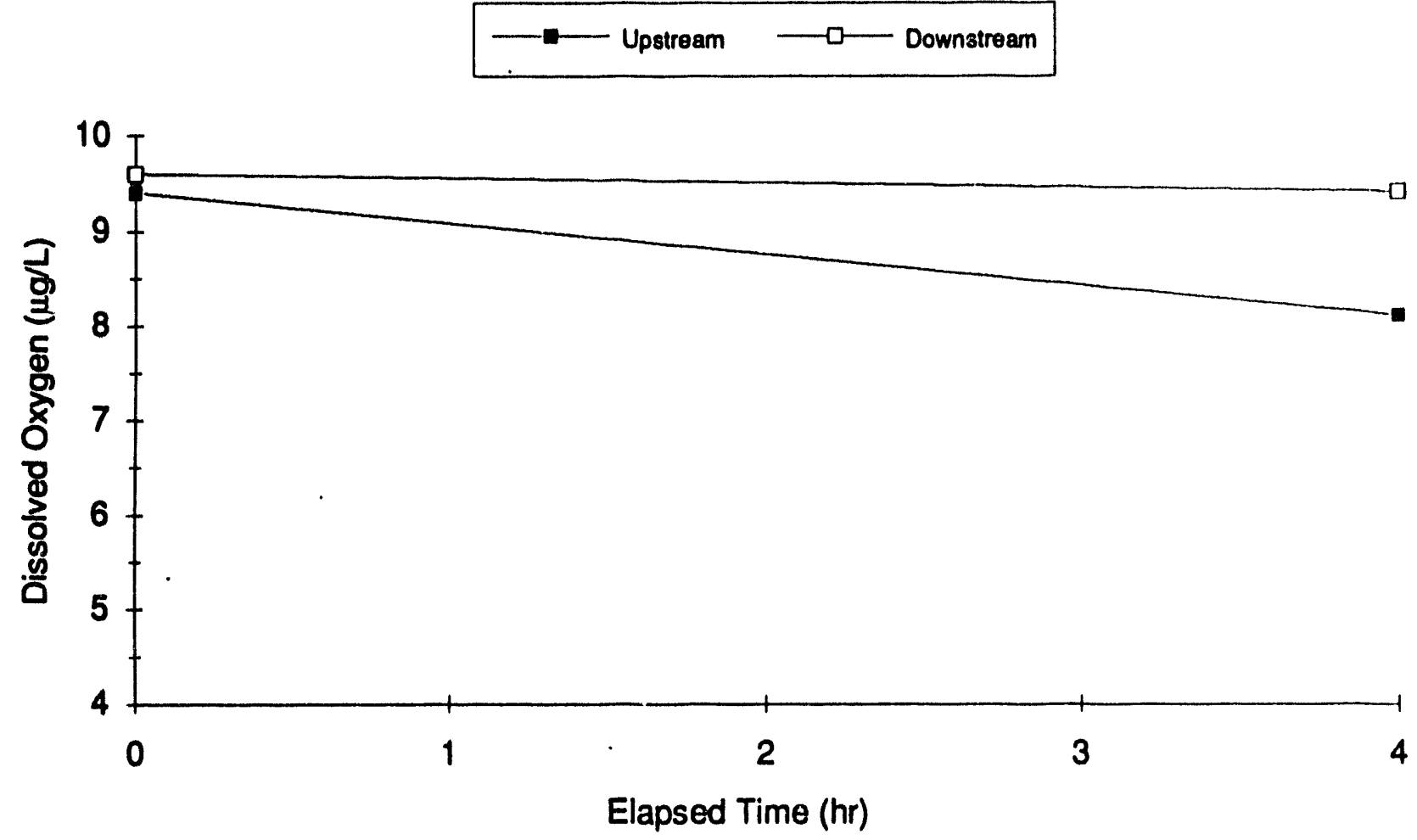

FIGURE B.29 Crossing \#2: Dissolved Oxygen Measured Upstream and $600 \mathrm{ft}$ Downstream versus Time
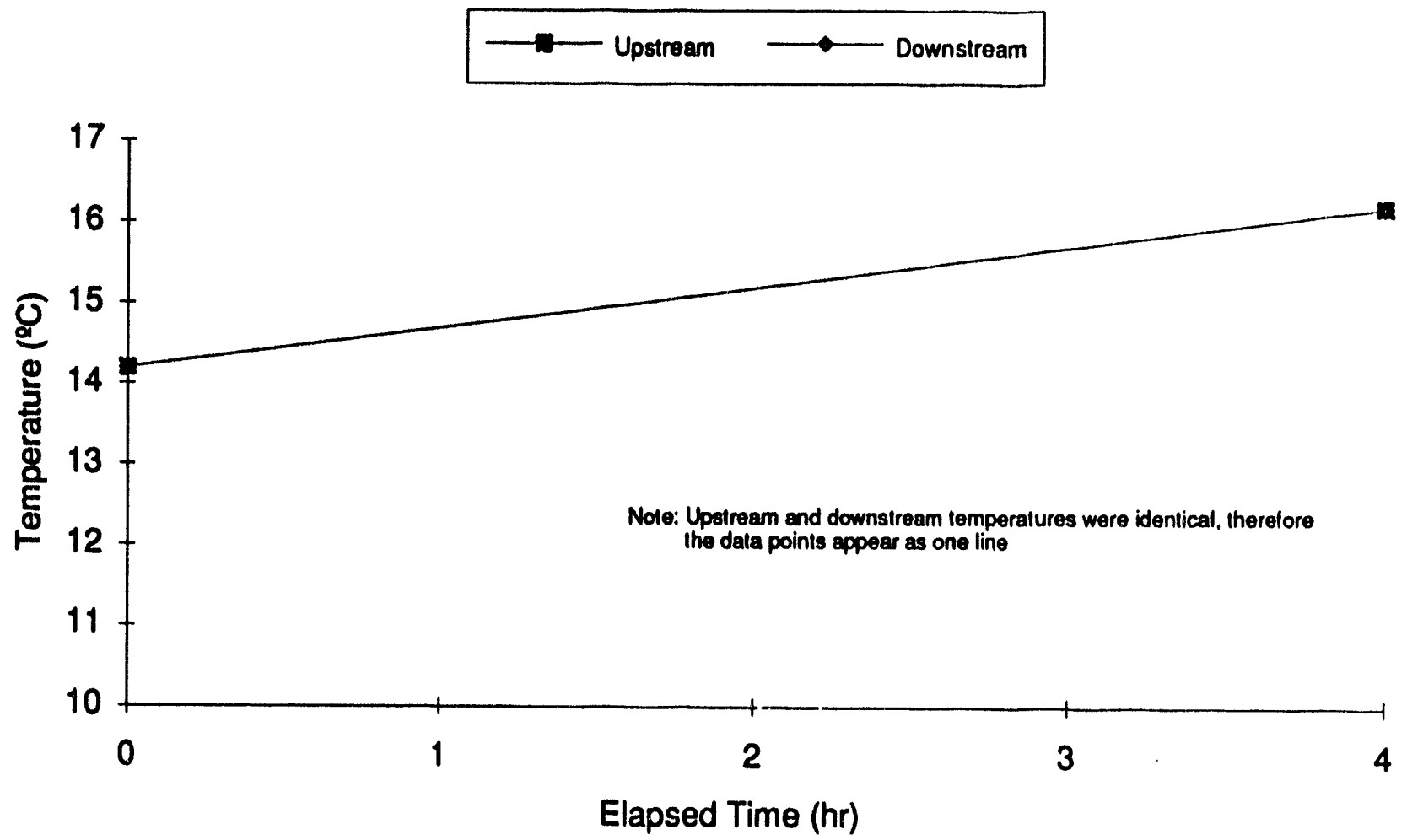

FIGURE B.30 Crossing \#2: Temperature Measured Upstream and $600 \mathrm{ft}$ Downstream versus Time 


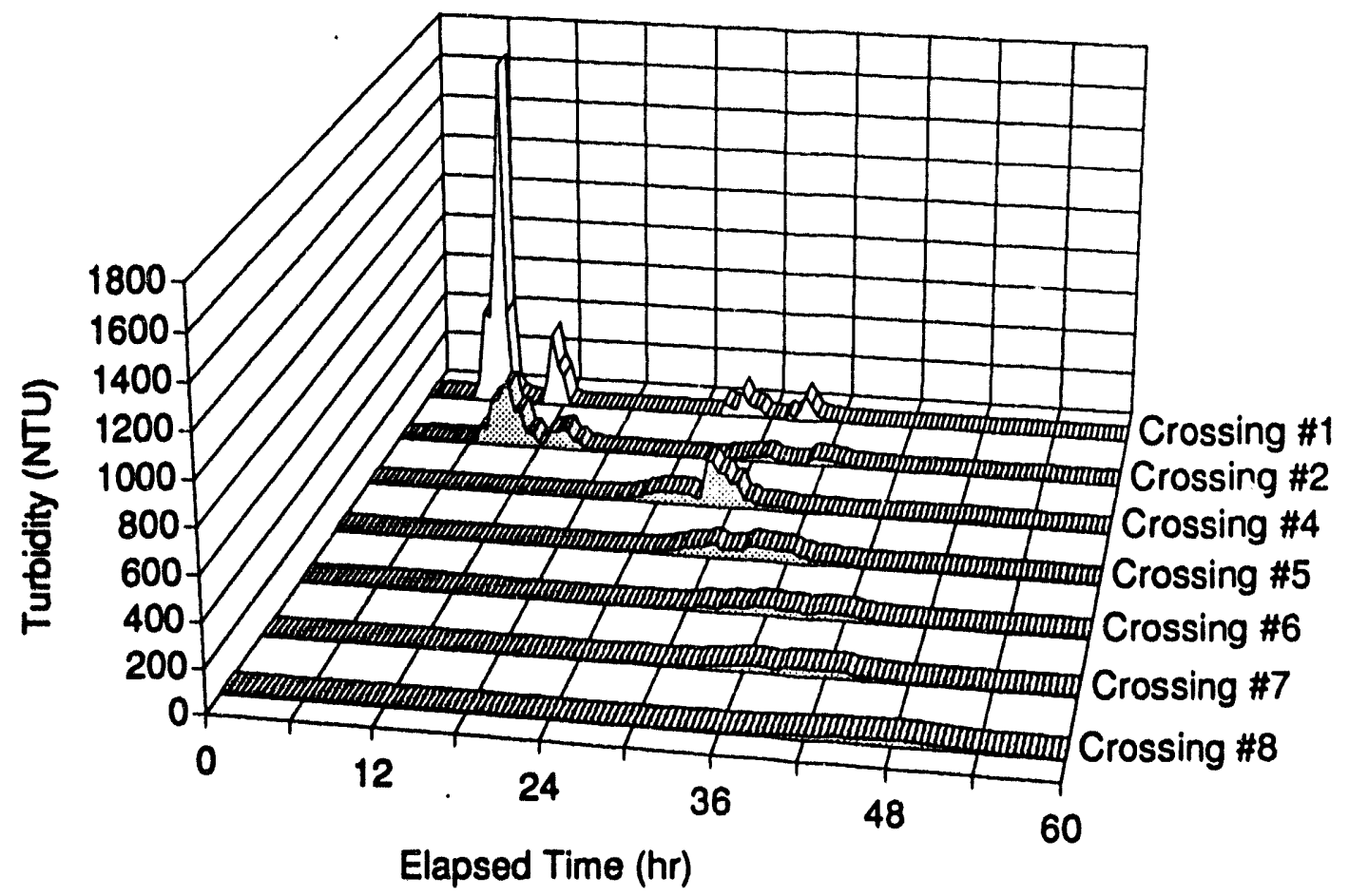

FIGURE B.31 Turbidity Generated by Crossing \#1 as Measured Downstream at Sampling Locations at Crossings \#2, \#4, \#5, \#6, \#7, and \#8

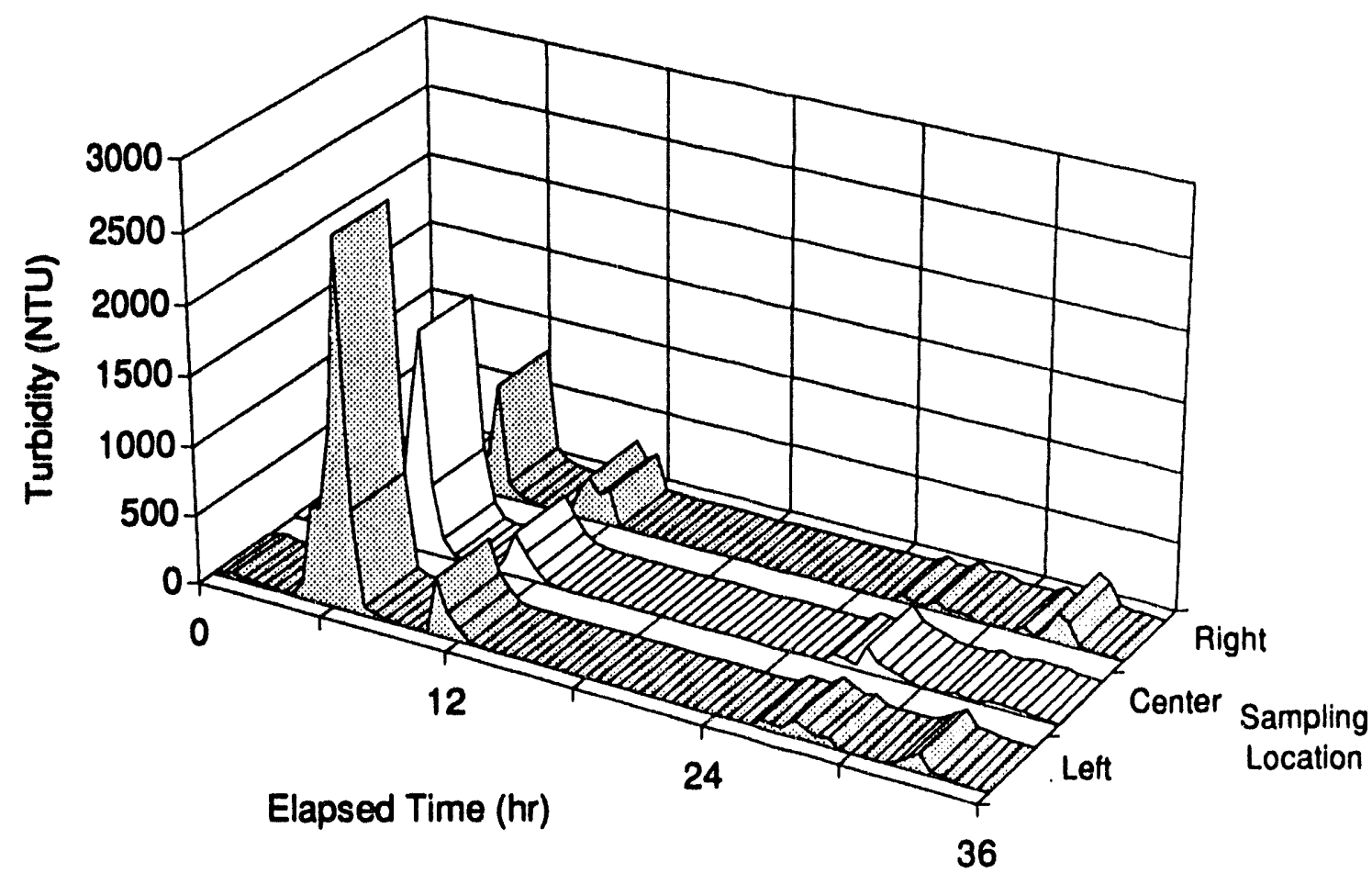

FIGURE B.32 Crossing \#1: Net Turbidity versus Time as Measured by Three Samplers $600 \mathrm{ft}$ Downstream 


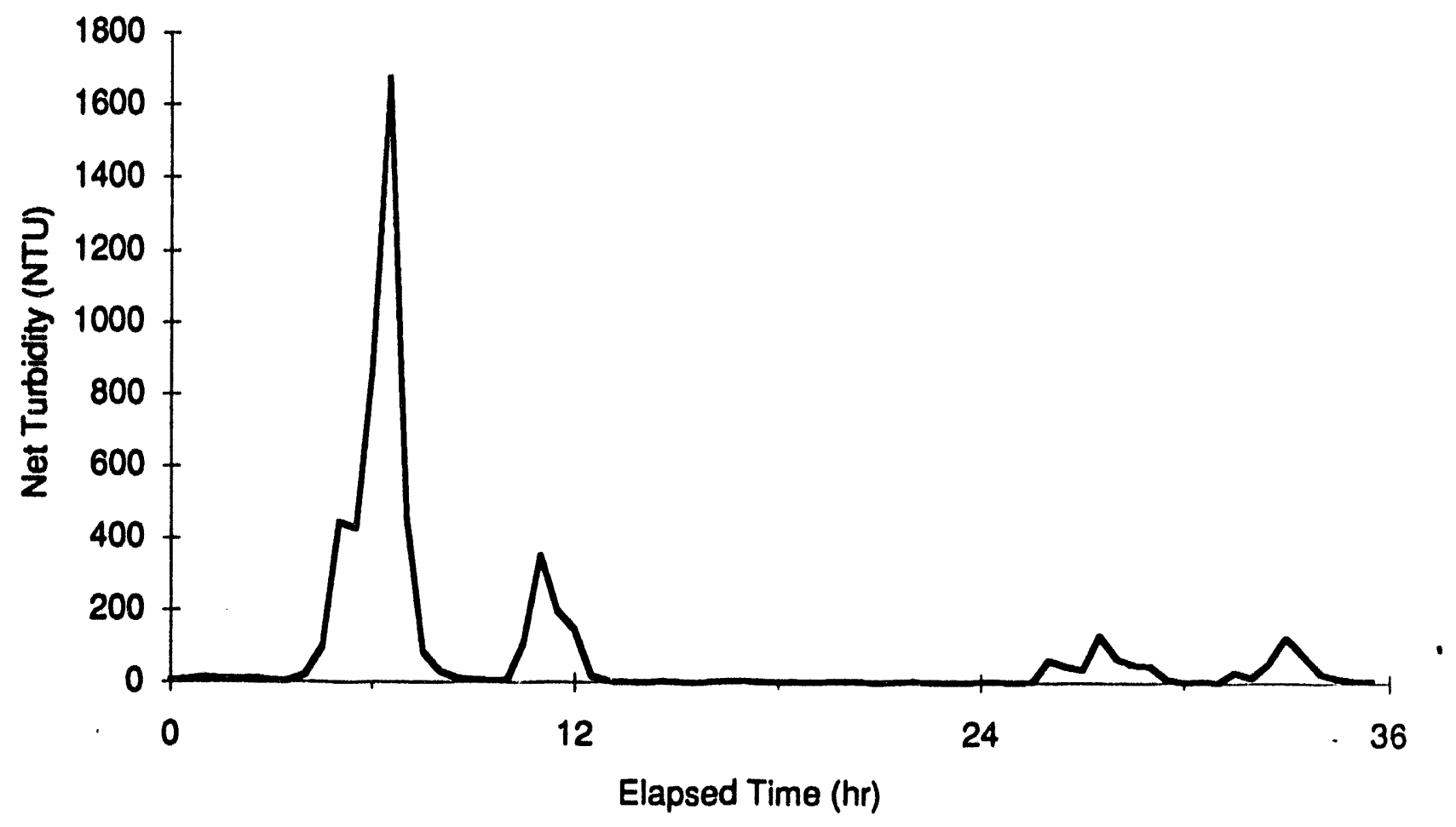

FIGURE B.33 Crossing \#1: Flow-Weighted Average of Net Turbidity Measured by Three Samplers $600 \mathrm{ft}$ Downstream versus Time

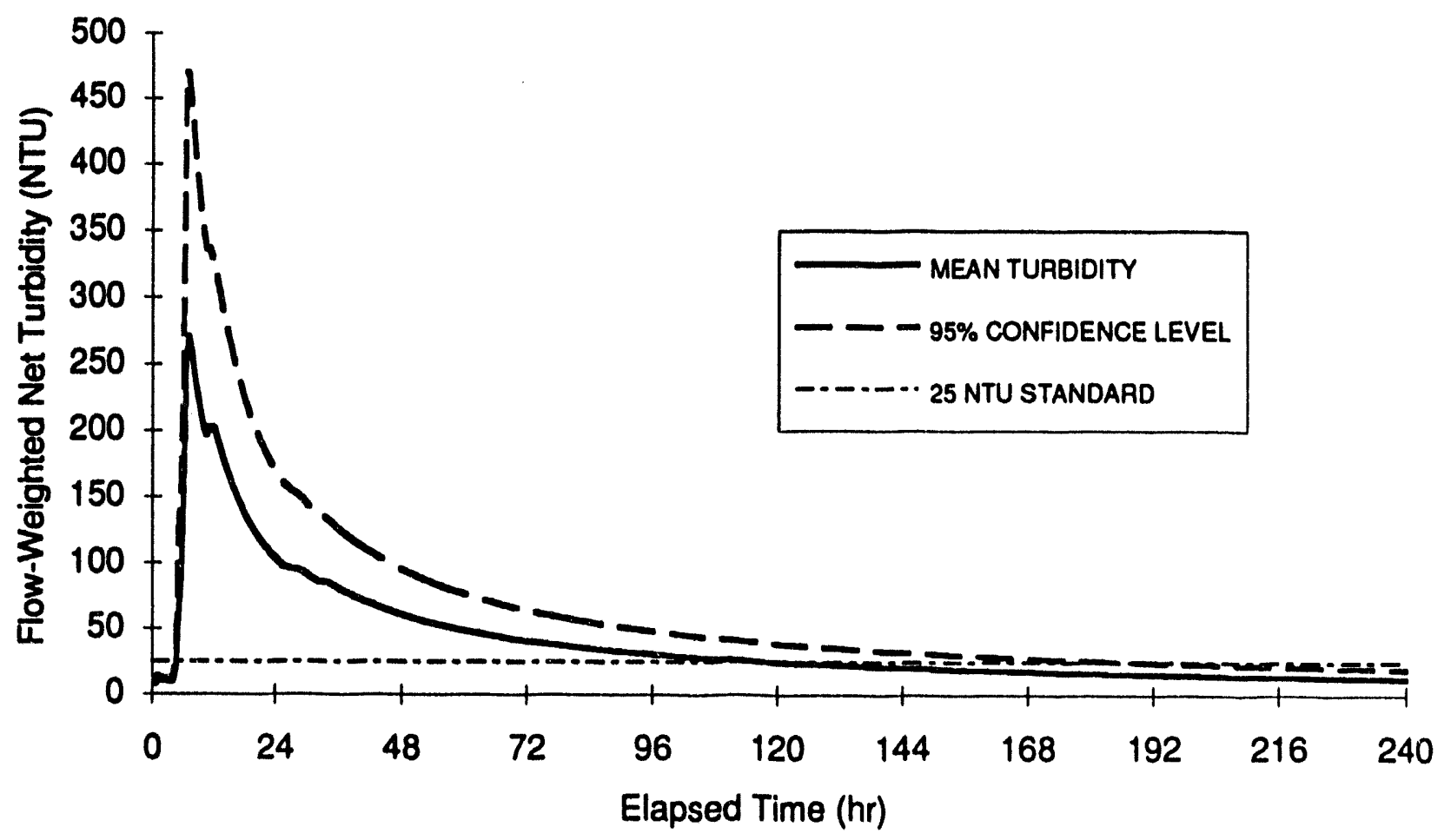

FIGURE B.34 Crossing \#1: Running Average of Flow-Weighted Net Turbidity as Measured $600 \mathrm{ft}$ Downstream versus Time 


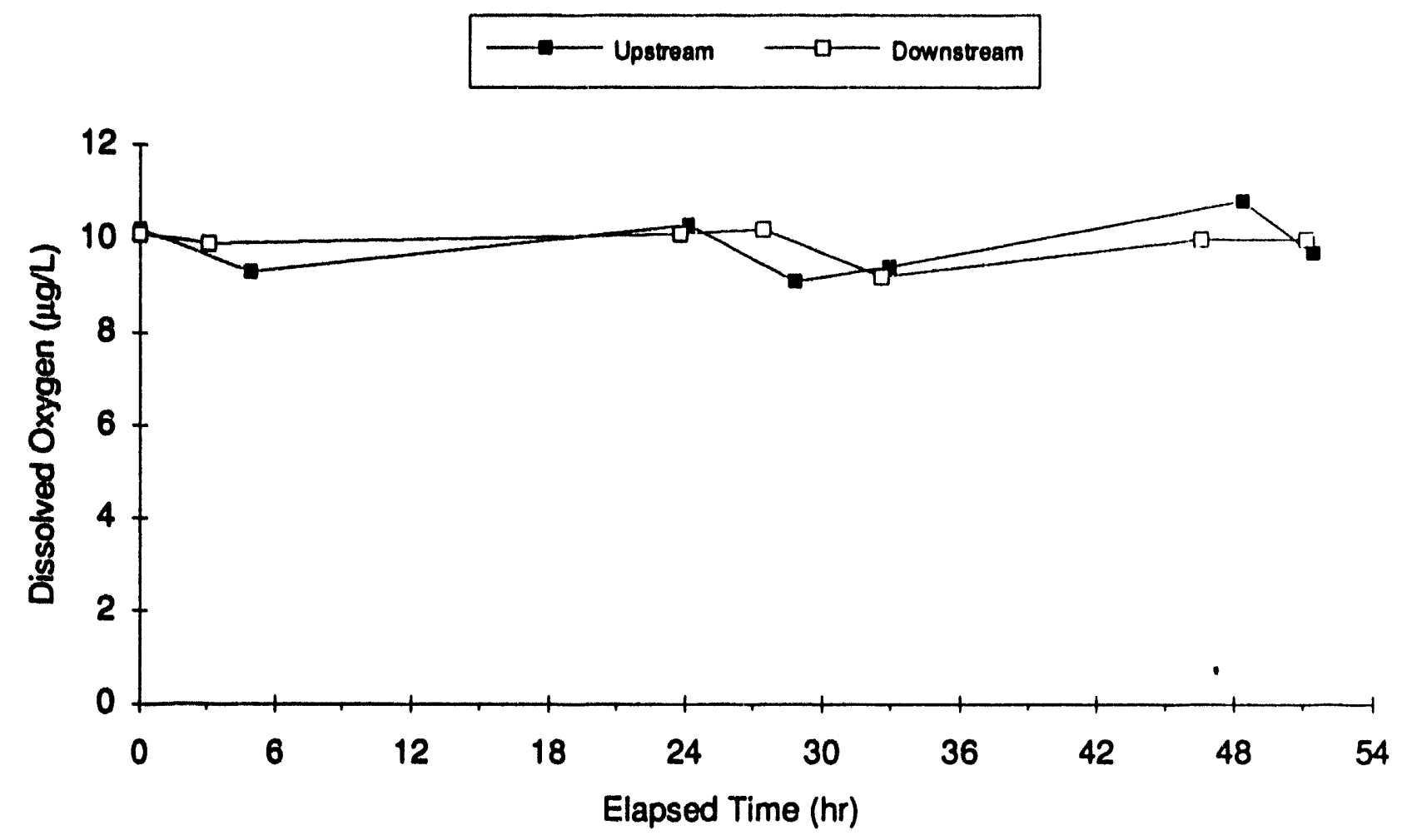

FIGURE B.35 Crossing \#1: Dissolved Oxygen Measured Upstream and $600 \mathrm{ft}$ Downstream versus Time
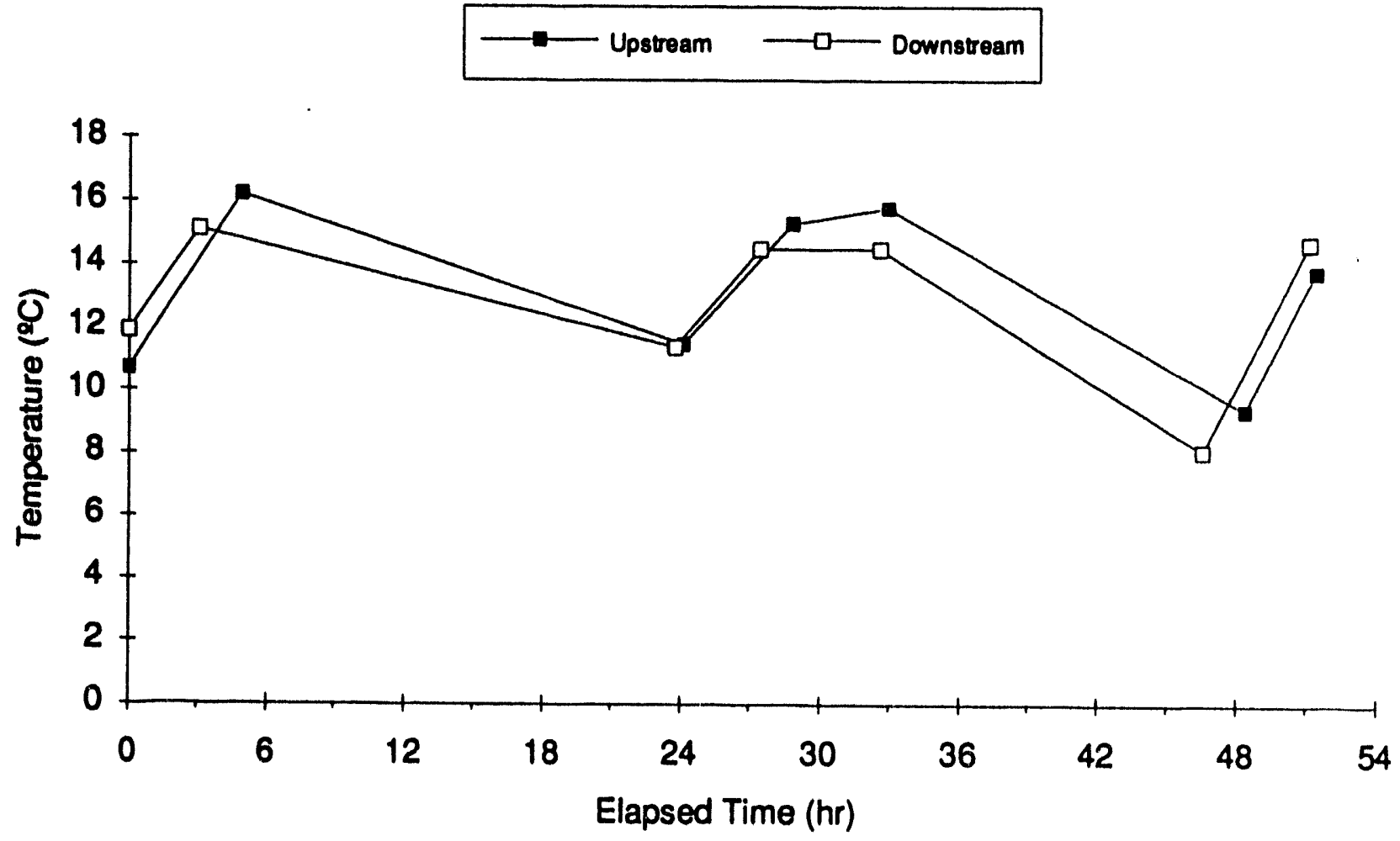

FIGURE B.36 Crossing \#1: Temperature Measured Upstream and $600 \mathrm{ft}$ Downstream versus Time 


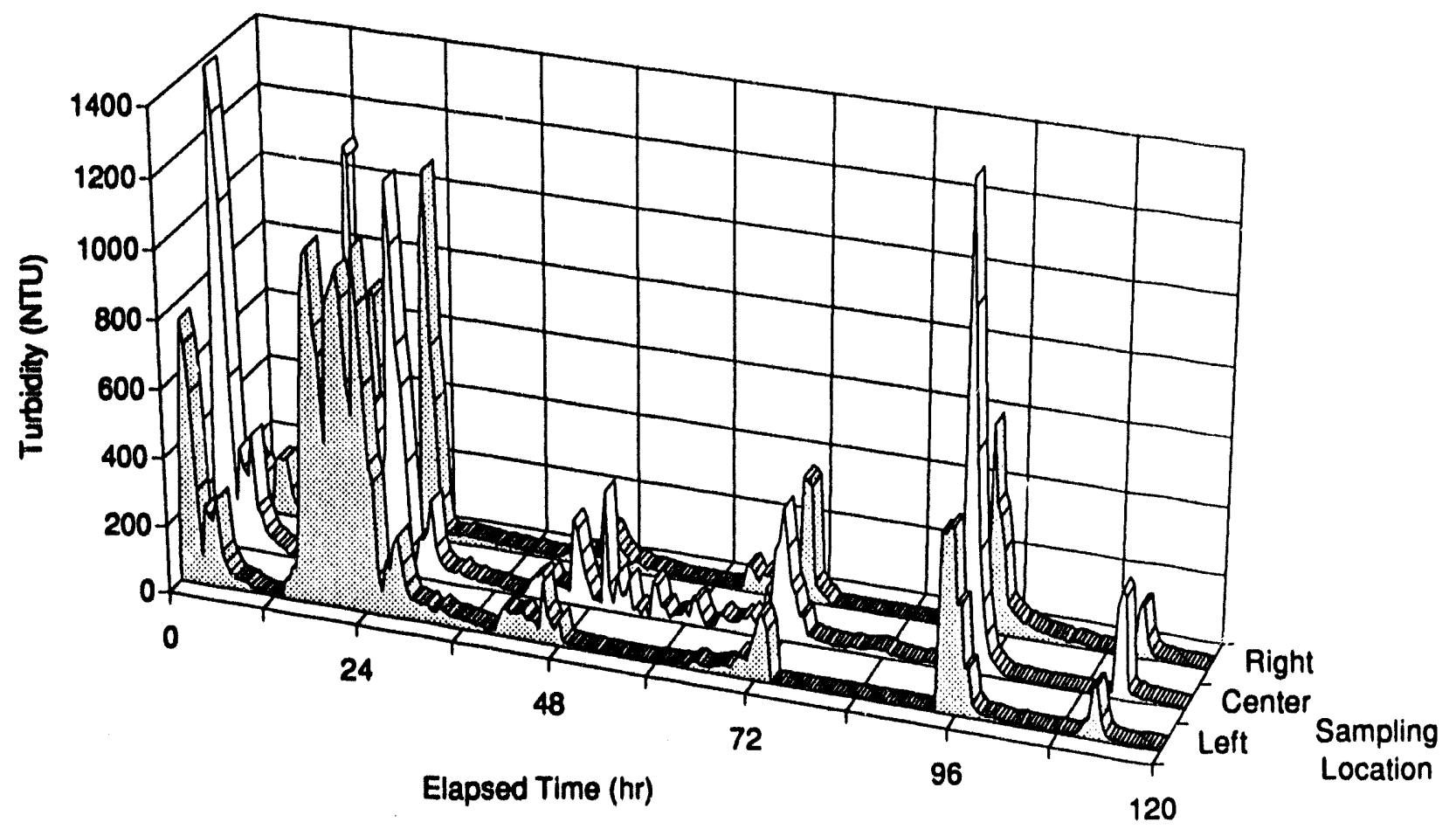

FIGURE B.37 Crossing \#3: Net Turbidity versus Time as Measured by Three Samplers $600 \mathrm{ft}$ Downstream

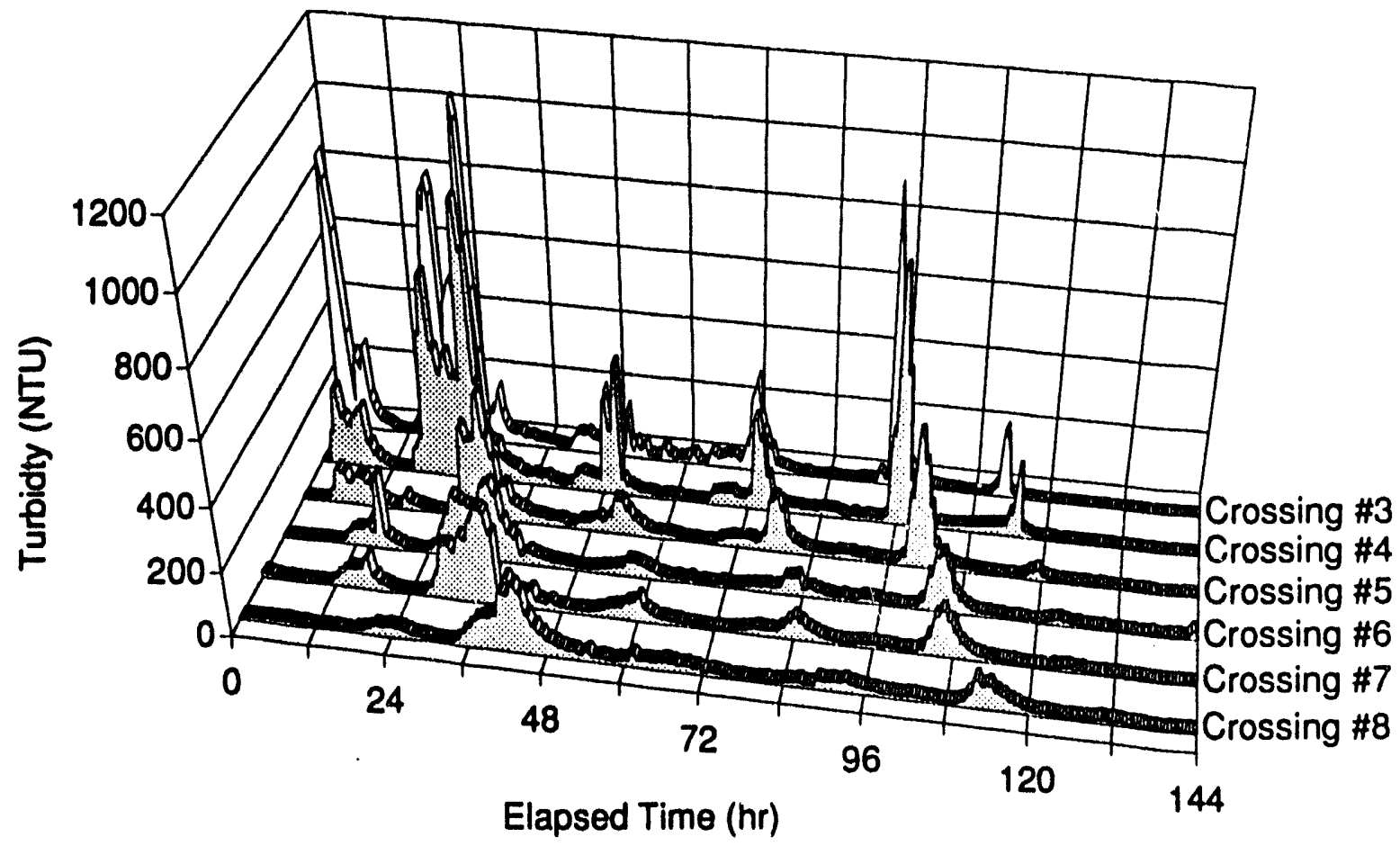

FIGURE B.38 Turbidity Generated by Crossing \#3 as Measured Downstream at Sampling Locations at Crossings \#3, \#4, \#5, \#6, \#7, and \#8 


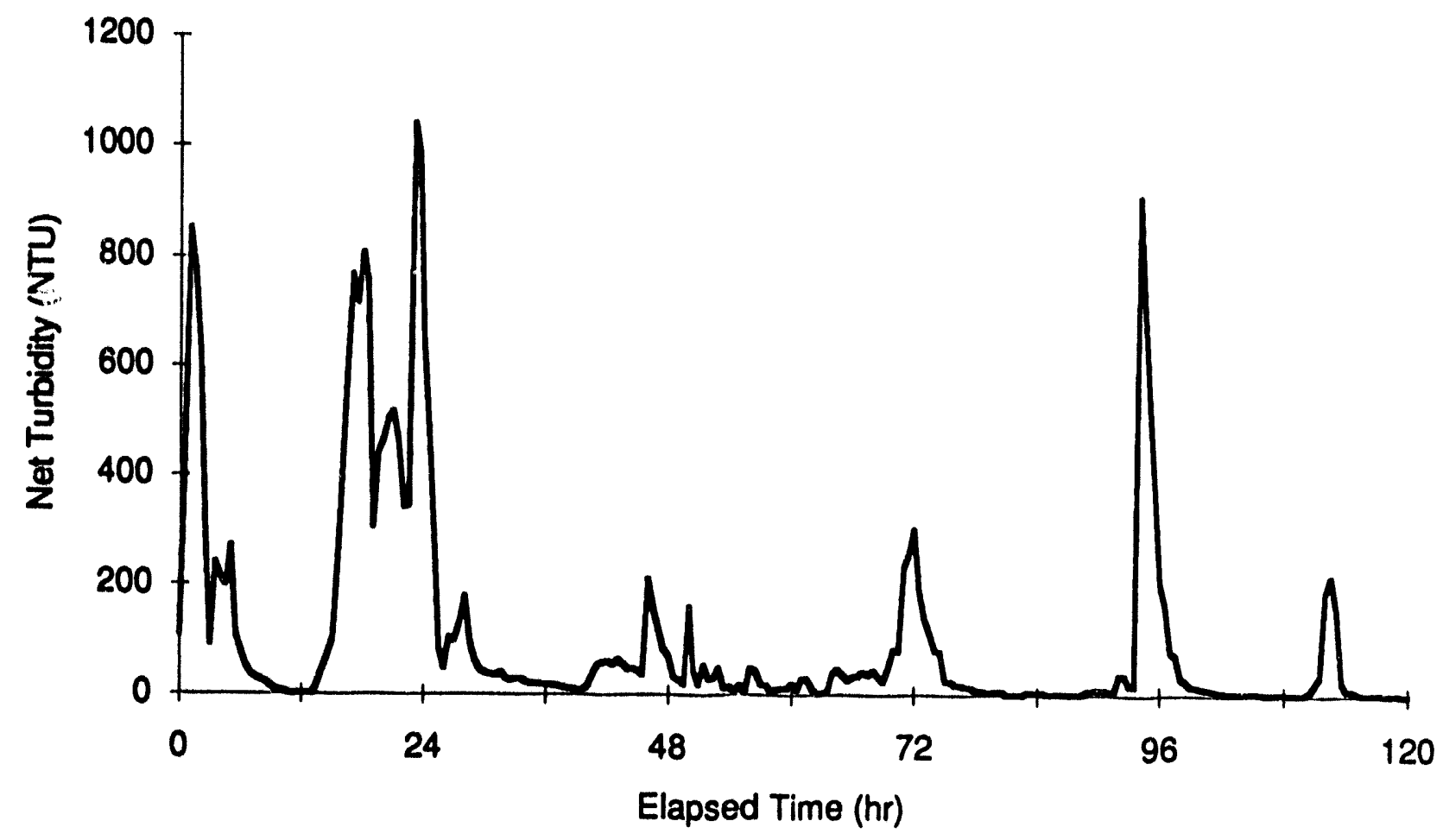

FIGURE B.39 Crossing \#3: Flow-Weighted Average of Net Turbidity Measured by Three Samplers $600 \mathrm{ft}$ Downstream versus Time

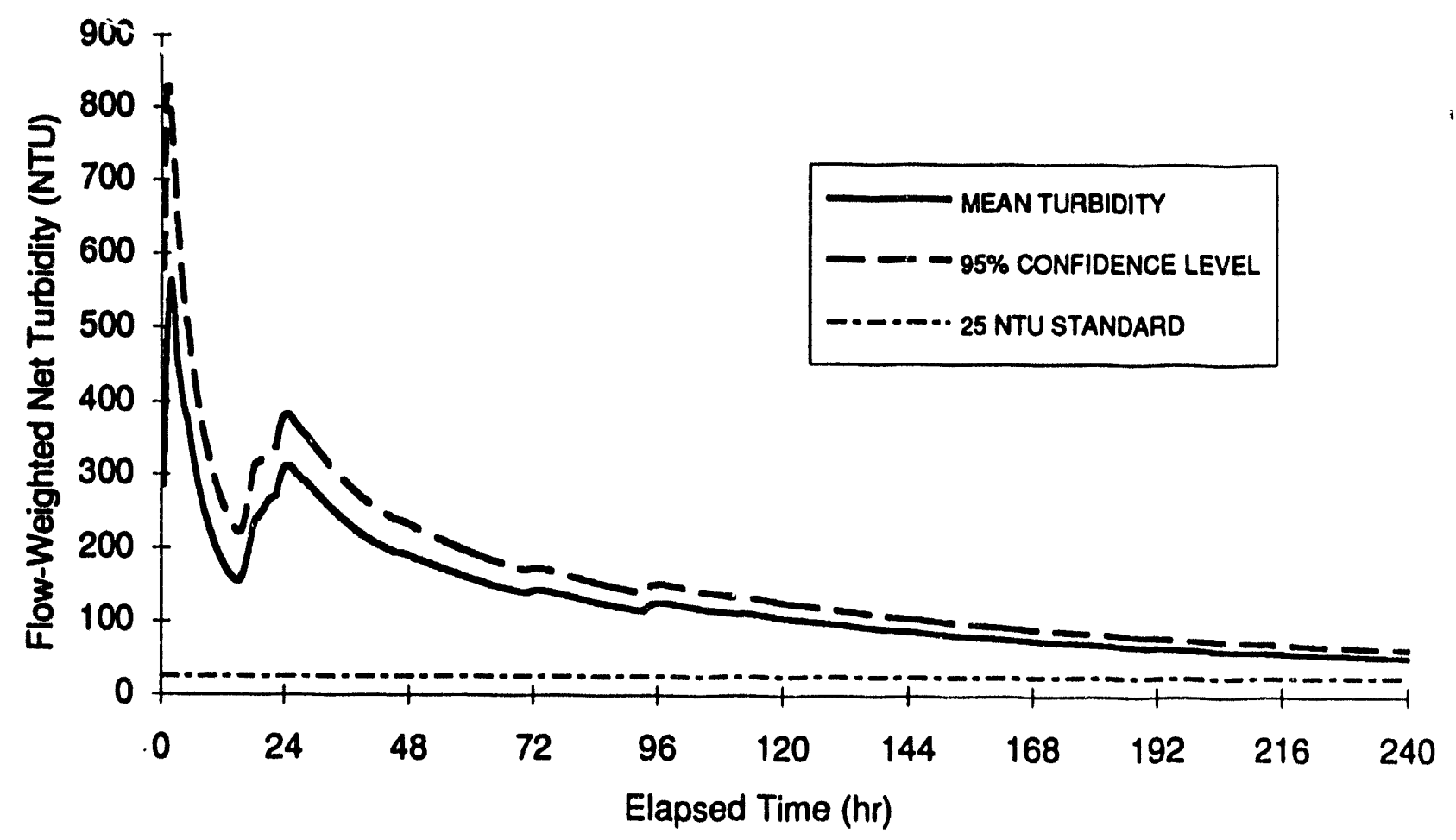

FIGURE B.40 Crossing \#3: Running Average of Flow-Weighted Net Turbidity as Measured $600 \mathrm{ft}$ Downstream versus Time 

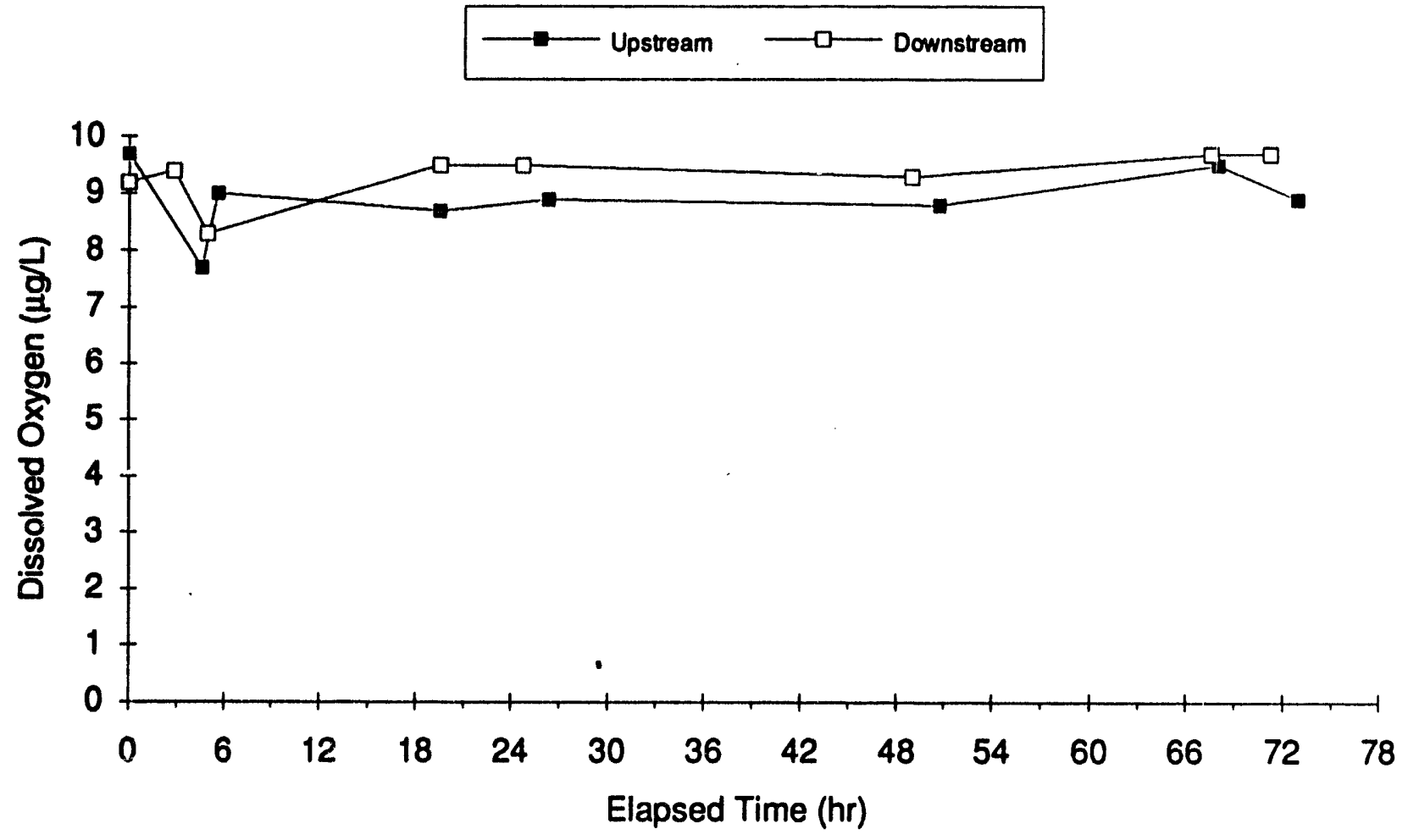

FIGURE B.41 Crossing \#3: Dissolved Oxygen Measured Upstream and $600 \mathrm{ft}$ Downstream versus Time
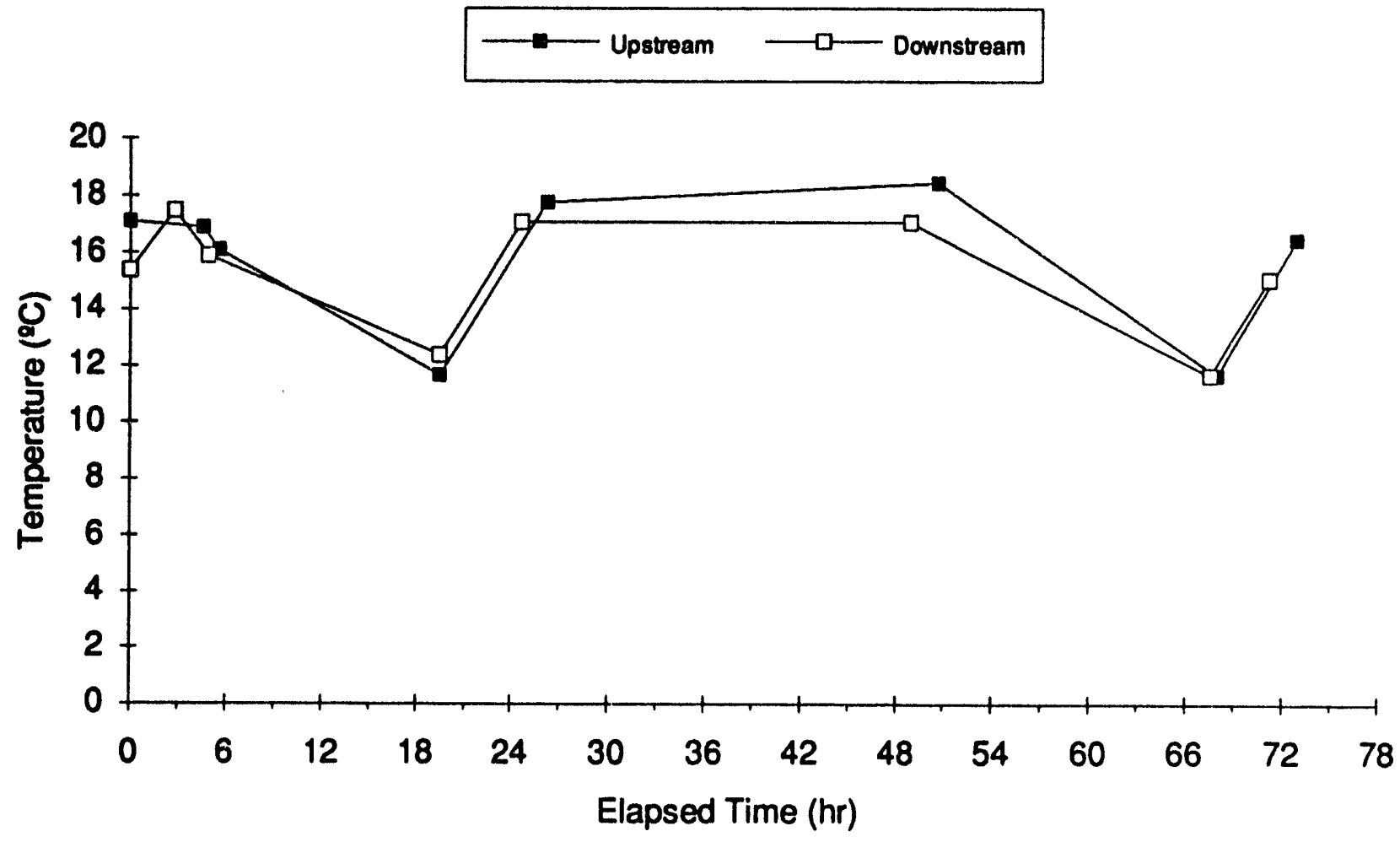

FIGURE B.42 Crossing \#3: Temperature Measured Upstream and $600 \mathrm{ft}$ Downstream versus Time 


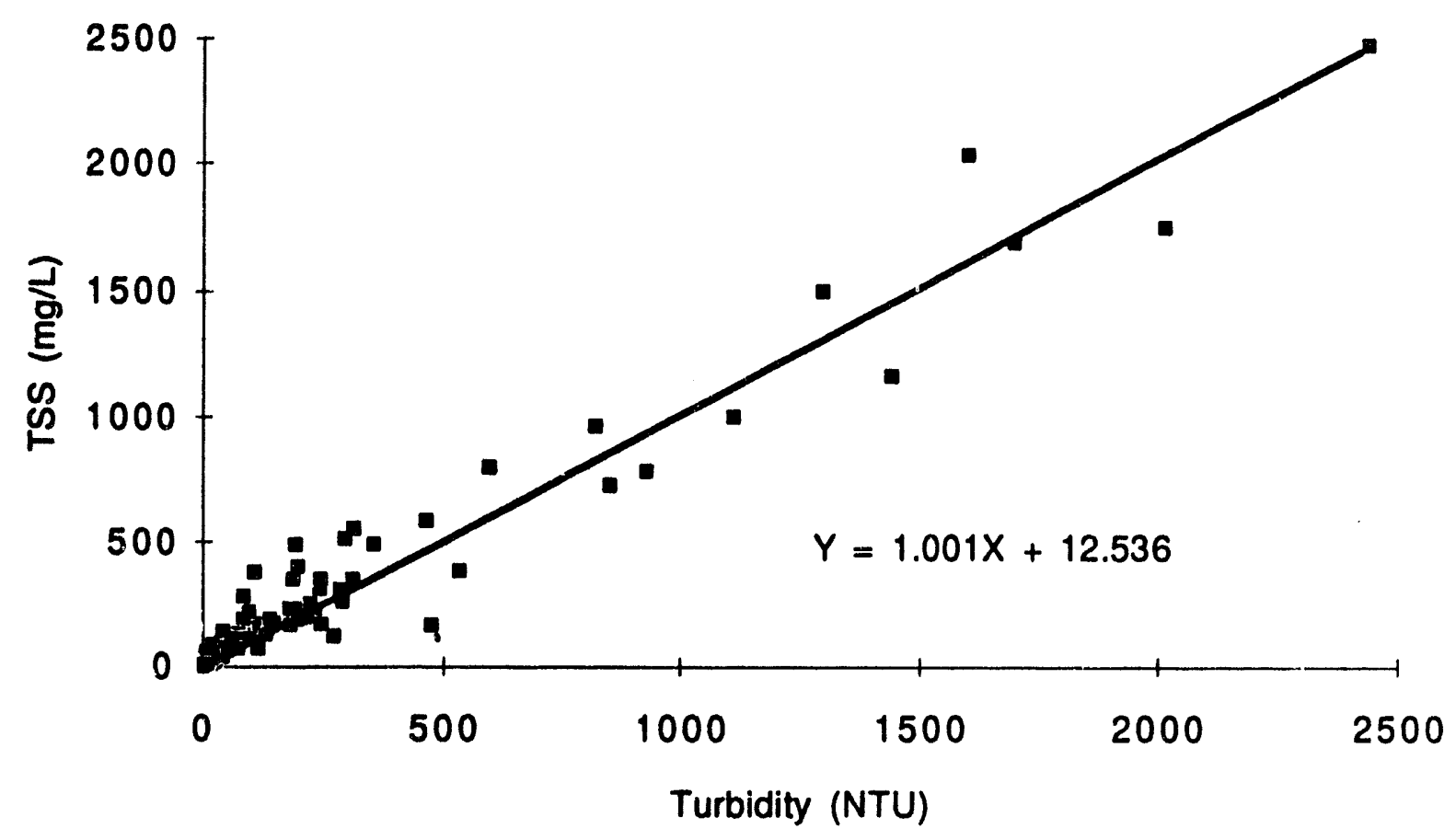

FIGURE B.43 Total Suspended Solids versus Turbidity for Crossing \#1

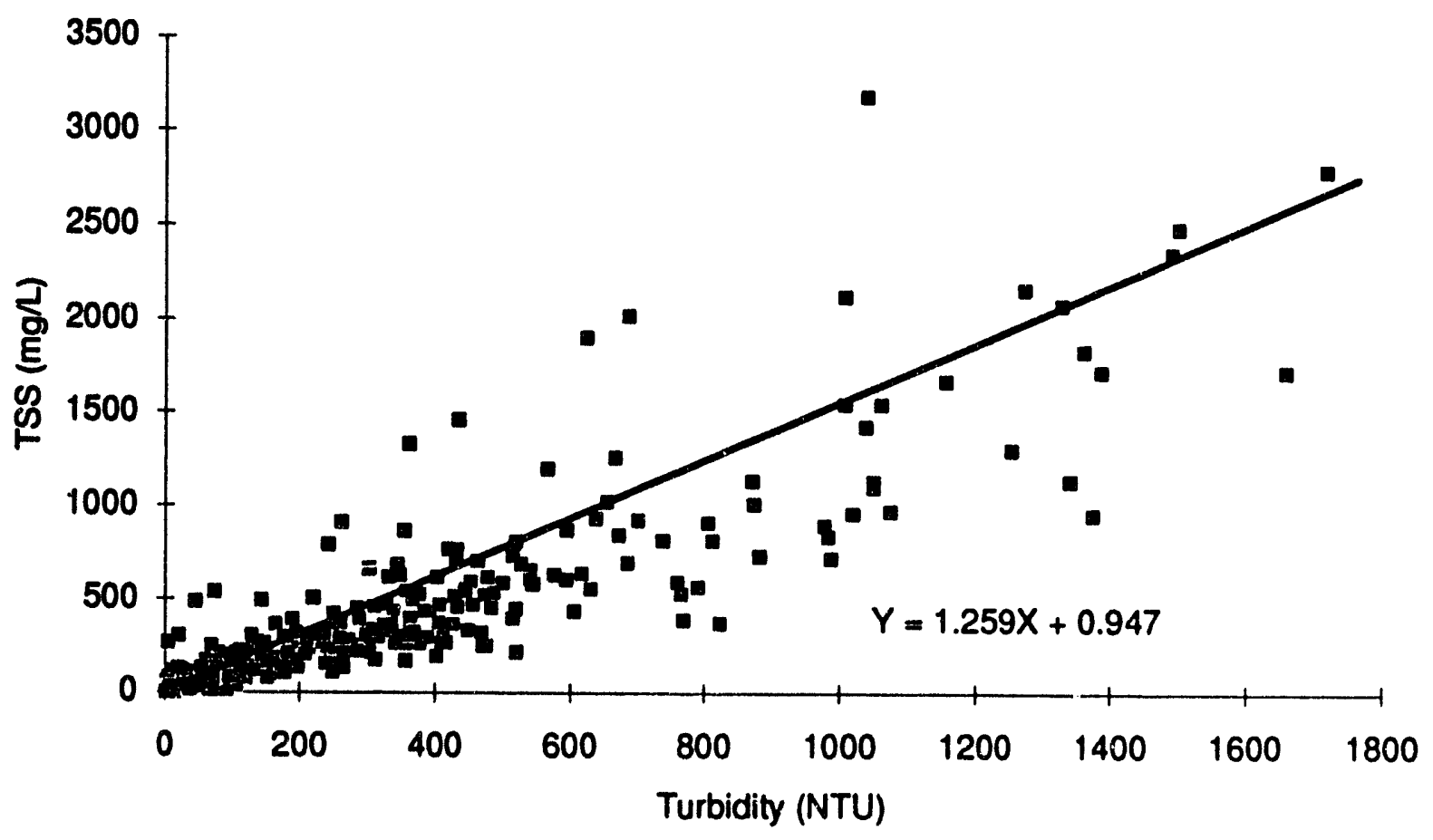

FIGURE B.44 Total Suspended Solids versus Turbidity for Crossing \#3 


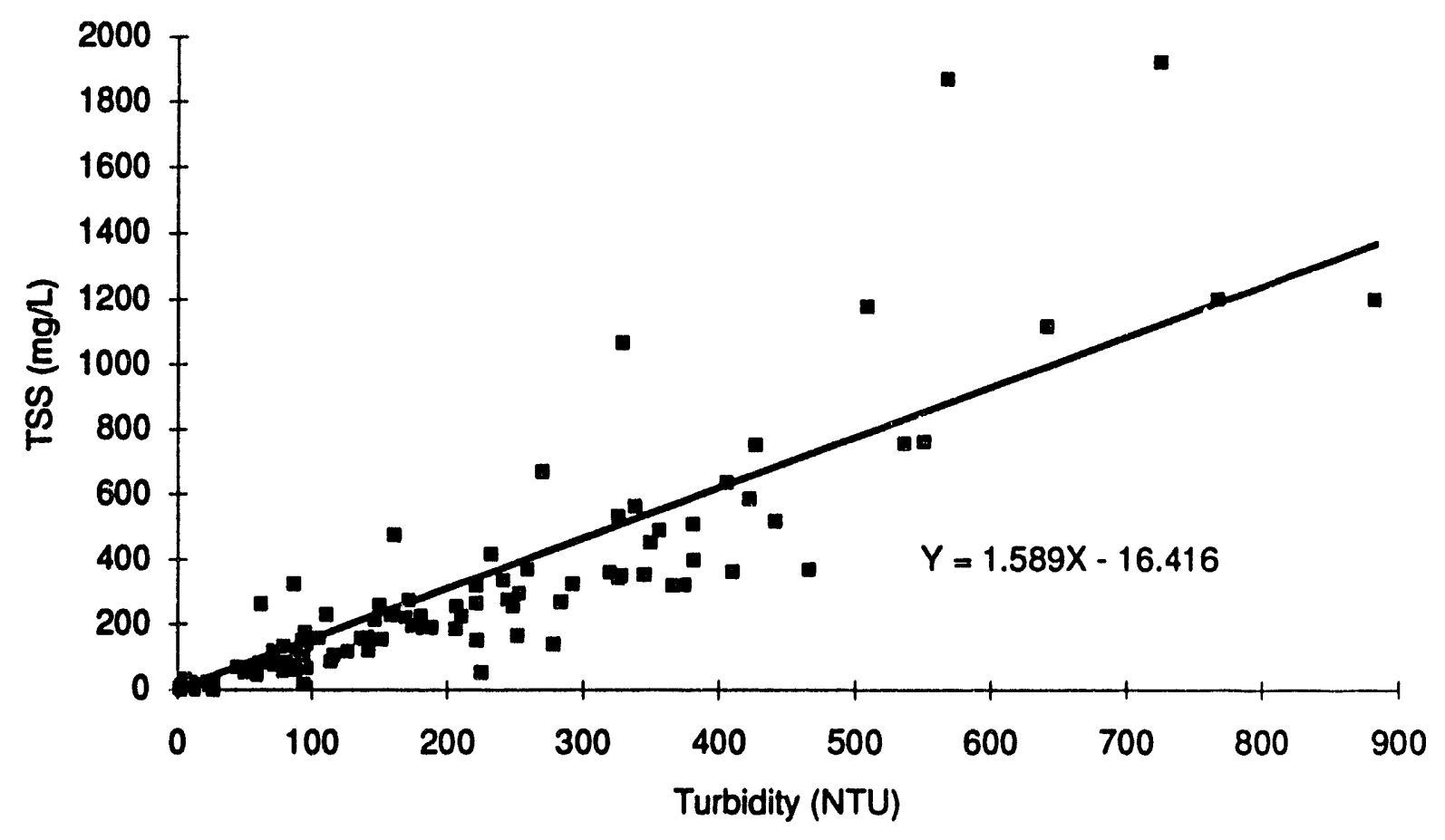

FIGURE B.45 Total Suspended Solids versus Turbidity for Crossing \#5

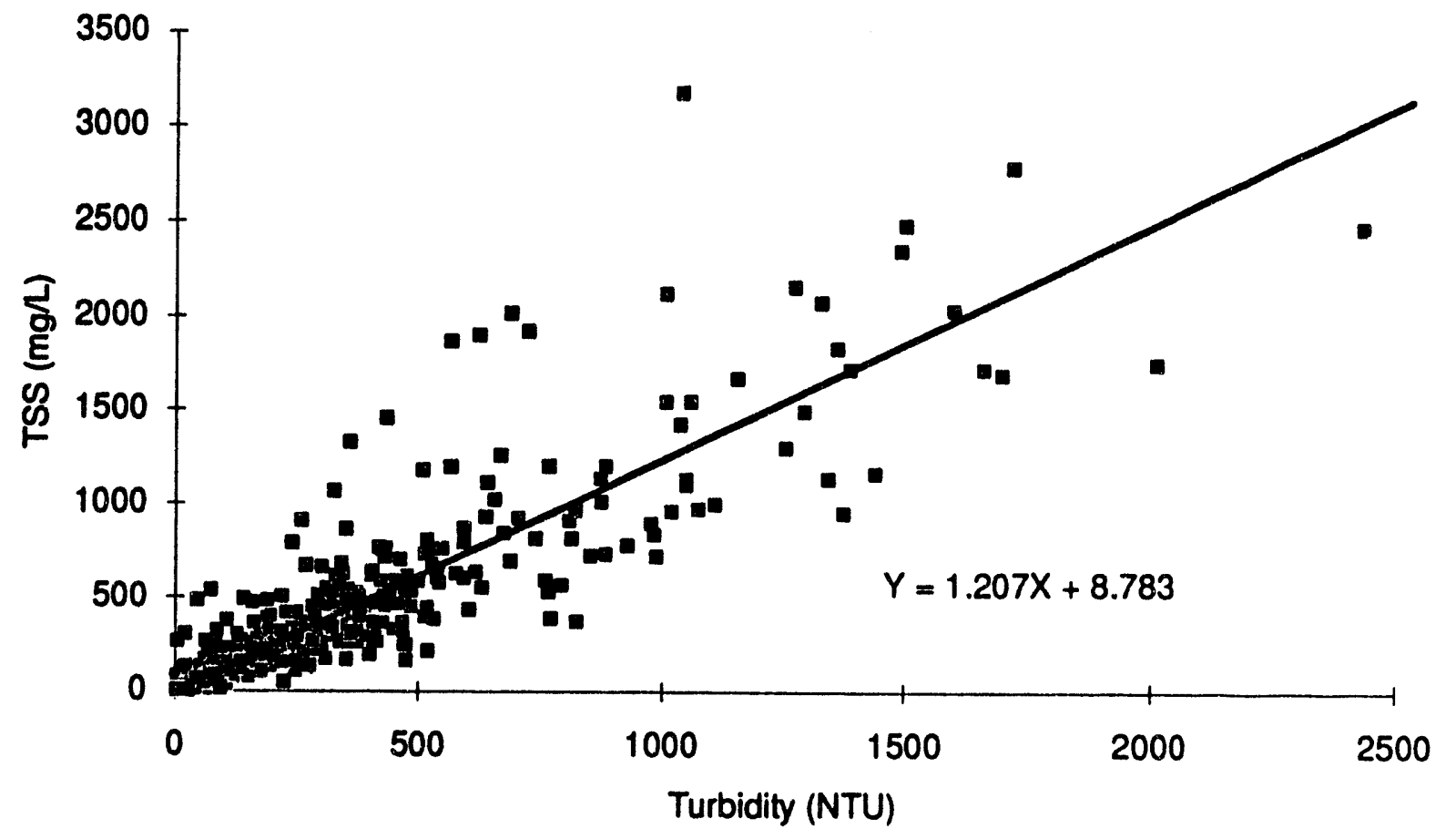

FIGURE B.46 Total Suspended Solids versus Turbidity for Crossings \#1, \#3, and \#5 
Appendix C:

Turbidity Data 
TABLE C.1 Turbidity Generated by Crossing \#8

\begin{tabular}{|c|c|c|c|c|c|c|c|}
\hline \multirow[b]{2}{*}{ Date } & \multirow[b]{2}{*}{ Time } & \multirow[b]{2}{*}{$\begin{array}{c}\text { Time Since } \\
\text { Last Sample } \\
\text { (min.) }\end{array}$} & \multirow[b]{2}{*}{$\begin{array}{c}\text { Elapsed } \\
\text { Time } \\
\text { (hours) }\end{array}$} & \multicolumn{4}{|c|}{ Turbidity (a) } \\
\hline & & & & $\begin{array}{r}\text { Background } \\
\text { (NTU) }\end{array}$ & & $\begin{array}{r}600 \mathrm{ft} \\
\text { Downstream } \\
(\mathrm{NTU}) \\
\end{array}$ & $\begin{array}{r}\text { Net (b) } \\
\text { (NTU) }\end{array}$ \\
\hline 27-Jul & $1: 30$ & 0 & 0.0 & 1 & & 2 & 1 \\
\hline 27-Jul & $2: 00$ & 30 & 0.5 & 1 & & $2 e$ & $1 e$ \\
\hline 27-Jul & $2: 30$ & 30 & 1.0 & 2 & & 72 & 70 \\
\hline 27-Jul & $3: 00$ & 30 & 1.5 & 2 & & $72 e$ & $70 e$ \\
\hline 27-Jul & $3: 30$ & 30 & 2.0 & 2 & & 184 & 182 \\
\hline 27-Jul & $4: 00$ & 30 & 2.5 & 2 & & $184 e$ & $182 e$ \\
\hline 27-Jul & $4: 30$ & 30 & 3.0 & 1 & & 88 & 87 \\
\hline 27-Jul & $5: 00$ & 30 & 3.5 & 1 & & $88 e$ & $87 \theta$ \\
\hline 27-Jul & $5: 30$ & 30 & 4.0 & 1 & & 186 & 185 \\
\hline 27-Jul & $6: 00$ & 30 & 4.5 & 1 & & $186 e$ & $185 e$ \\
\hline 27-Jul & $6: 30$ & 30 & 5.0 & 2 & & 216 & 214 \\
\hline 27-Jul & $7: 00$ & 30 & 5.5 & 2 & & $216 e$ & $214 e$ \\
\hline 27-Jul & $7: 30$ & 30 & 6.0 & 1 & & 162 & 161 \\
\hline 27-Jul & $8: 00$ & 30 & 6.5 & 1 & & $162 e$ & $161 e$ \\
\hline 27-Jul & $8: 30$ & 30 & 7.0 & 2 & & 152 & 150 \\
\hline 27-Jul & $9: 00$ & 30 & 7.5 & 1 & & 90 & 89 \\
\hline 27-Jul & $9: 30$ & 30 & 8.0 & 1 & & 111 & 110 \\
\hline 27-Jul & $10: 00$ & 30 & 8.5 & 2 & & 128 & 126 \\
\hline 27-Jul & $10: 30$ & 30 & 9.0 & 1 & & 49 & 48 \\
\hline 27-Jul & $11: 00$ & 30 & 9.5 & 1 & & 36 & 35 \\
\hline 27-Jul & $11: 30$ & 30 & 10.0 & 1 & & 46 & 45 \\
\hline 27-Jul & $12: 00$ & 30 & 10.5 & 1 & & 48 & 47 \\
\hline 27-Jul & $12: 30$ & 30 & 11.0 & 1 & & 20 & 19 \\
\hline 27-Jul & $13: 00$ & 30 & 11.5 & 2 & & 8 & 6 \\
\hline 27-Jul & $13: 30$ & 30 & 12.0 & 2 & & 15 & 13 \\
\hline 27-Jul & $14: 00$ & 30 & 12.5 & 2 & & 41 & 39 \\
\hline 27-Jul & $14: 30$ & 30 & 13.0 & 1 & & 32 & 31 \\
\hline 27-Jul & $15: 00$ & 30 & 13.5 & 1 & & 30 & 29 \\
\hline 27-Jul & $15: 30$ & 30 & 14.0 & 1 & & 34 & 33 \\
\hline 27-Jul & $16: 00$ & 30 & 14.5 & 1 & & 40 & 39 \\
\hline 27-Jul & $16: 30$ & 30 & 15.0 & 1 & & 45 & 44 \\
\hline 27-Jul & $17: 00$ & 30 & 15.5 & 2 & & 68 & 66 \\
\hline 27-Jul & $17: 30$ & 30 & 16.0 & 2 & & 46 & 44 \\
\hline 27-Jul & $18: 00$ & 30 & 16.5 & 1 & & 36 & 35 \\
\hline 27-Jul & $18: 30$ & 30 & 17.0 & 1 & & 27 & 26 \\
\hline 27-Jul & $19: 00$ & 30 & 17.5 & 1 & & 28 & 27 \\
\hline 27-Jul & 19:30 & 30 & 18.0 & 1 & & 15 & 14 \\
\hline 27-Jul & $20: 00$ & 30 & 18.5 & 1 & $m$ & 8 & 7 \\
\hline 27-Jul & $20: 30$ & 30 & 19.0 & 1 & $m$ & 5 & 4 \\
\hline 27-Jul & $21: 00$ & 30 & 19.5 & 1 & & 4 & 3 \\
\hline 27-Jul & $21: 30$ & 30 & 20.0 & 1 & $m$ & 3 & 2 \\
\hline
\end{tabular}


TABLE C.1 (Cont.)

\begin{tabular}{|c|c|c|c|c|c|c|c|}
\hline \multirow[b]{2}{*}{ Date } & \multirow[b]{2}{*}{ Time } & \multirow[b]{2}{*}{$\begin{array}{c}\text { Time Since } \\
\text { Last Sample } \\
\text { (min.) }\end{array}$} & \multirow[b]{2}{*}{$\begin{array}{c}\text { Elapsed } \\
\text { Time } \\
\text { (hours) }\end{array}$} & \multicolumn{4}{|c|}{ Turbidity (a) } \\
\hline & & & & $\begin{array}{r}\text { Background } \\
\text { (NTU) }\end{array}$ & & $\begin{array}{r}600 \mathrm{ft} \\
\text { Downstream } \\
(\mathrm{NTU})\end{array}$ & $\begin{array}{l}\text { Net (b) } \\
\text { (NTU) }\end{array}$ \\
\hline $27-J u l$ & $22: 00$ & 30 & 20.5 & 1 & $m$ & 3 & 2 \\
\hline 27-Jul & $22: 30$ & 30 & 21.0 & 1 & $m$ & 3 & 2 \\
\hline 27-Jul & 23:00 & 30 & 21.5 & 1 & & 3 & 2 \\
\hline 27-Jul & $23: 30$ & 30 & 22.0 & 1 & $m$ & 3 & 2 \\
\hline 28-Jul & $0: 00$ & 30 & 22.5 & 1 & m & 3 & 2 \\
\hline 28-Jul & $0: 30$ & 30 & 23.0 & 1 & m & 3 & 2 \\
\hline 28-Jul & $1: 00$ & 30 & 23.5 & 2 & & 3 & 1 \\
\hline 28-Jul & $1: 30$ & 30 & 24.0 & 2 & m & 2 & 0 \\
\hline 28-Jul & $2: 00$ & 30 & 24.5 & 2 & $m$ & 2 & 0 \\
\hline 28-Jul & $2: 30$ & 30 & 25.0 & 2 & m & 4 & 2 \\
\hline 28-Jul & $3: 00$ & 30 & 25.5 & 2 & & 2 & 0 \\
\hline 28-Jul & $3: 30$ & 30 & 26.0 & 2 & $m$ & 3 & 1 \\
\hline 28-Jul & $4: 00$ & 30 & 26.5 & 2 & $m$ & 2 & 0 \\
\hline 28-Jul & $4: 30$ & 30 & 27.0 & 3 & $m$ & 1 & 0 \\
\hline 28-Jul & $5: 00$ & 30 & 27.5 & 3 & & 1 & 0 \\
\hline 28-Jul & $5: 30$ & 30 & 28.0 & 3 & $m$ & 2 & 0 \\
\hline 28-Jul & $6: 00$ & 30 & 28.5 & 2 & $m$ & 1 & 0 \\
\hline 28-Jul & $6: 30$ & 30 & 29.0 & 2 & $m$ & 2 & 0 \\
\hline 28-Jul & $7: 00$ & 30 & 29.5 & 2 & $m$ & $2 \theta$ & $0 \mathrm{e}$ \\
\hline 28-Jul & $7: 30$ & 30 & 30.0 & 1.5 & & 23 & 21.5 \\
\hline 28-Jul & $8: 00$ & 30 & 30.5 & 1.5 & $m$ & 20 & 18.5 \\
\hline 28-Jul & $8: 30$ & 30 & 31.0 & 2 & $m$ & 36 & 34 \\
\hline 28-Jul & 9:00 & 30 & 31.5 & 2 & & 35 & 33 \\
\hline 28-Jul & $9: 30$ & 30 & 32.0 & 2 & $m$ & 156 & 154 \\
\hline 28-Jul & $10: 00$ & 30 & 32.5 & 2 & $m$ & 144 & 142 \\
\hline 28-Jul & $10: 30$ & 30 & 33.0 & 3 & $m$ & 23 & 20 \\
\hline 28-Jul & $11: 00$ & 30 & 33.5 & 3 & & 9 & 6 \\
\hline 28-Jul & $11: 30$ & 30 & 34.0 & 3 & $m$ & 5 & 2 \\
\hline 28-Jul & $12: 00$ & 30 & 34.5 & 3 & $m$ & 3 & 0 \\
\hline 28-Jul & $12: 30$ & 30 & 35.0 & 3 & $m$ & 3 & 0 \\
\hline 28-Jul & 13:00 & 30 & 35.5 & 3 & & 5 & 2 \\
\hline 28-Jul & $13: 30$ & 30 & 36.0 & 3 & $m$ & 2 & 0 \\
\hline 28-Jul & $14: 00$ & 30 & 36.5 & 4 & $m$ & 1 & 0 \\
\hline 28-Jul & $14: 30$ & 30 & 37.0 & 4 & $\mathrm{~m}$ & 1 & 0 \\
\hline 28-Jul & $15: 00$ & 30 & 37.5 & 4 & & 3 & 0 \\
\hline 28-Jul & $15: 30$ & 30 & 38.0 & 4 & $m$ & 3 & 0 \\
\hline 28-Jul & $16: 00$ & 30 & 38.5 & 4 & $m$ & 1 & 0 \\
\hline 28-Jul & $16: 30$ & 30 & 39.0 & 3 & $m$ & 2 & 0 \\
\hline 28-Jul & $17: 00$ & 30 & 39.5 & 3 & $m$ & 2 & 0 \\
\hline 28-Jul & $17: 30$ & 31 & 40.0 & 3 & $m$ & 1 & 0 \\
\hline 28-Jul & $18: 00$ & 30 & 40.5 & 3 & $m$ & 2 & 0 \\
\hline
\end{tabular}


TABLE C.1 (Cont.)

\begin{tabular}{|c|c|c|c|c|c|c|}
\hline \multirow[b]{2}{*}{ Date } & \multirow[b]{2}{*}{ Time } & \multirow[b]{2}{*}{$\begin{array}{c}\text { Time Since } \\
\text { Last Sample } \\
\text { (min.) }\end{array}$} & \multirow[b]{2}{*}{$\begin{array}{c}\text { Elapsed } \\
\text { Time } \\
\text { (hours) }\end{array}$} & \multicolumn{3}{|c|}{ Turbidity (a) } \\
\hline & & & & $\begin{array}{r}\text { Background } \\
\text { (NTU) }\end{array}$ & $\begin{array}{r}600 \mathrm{ft} \\
\text { Downstream } \\
(\mathrm{NTU})\end{array}$ & $\begin{array}{l}\text { Net (b) } \\
\text { (NTU) }\end{array}$ \\
\hline 28-Jul & $18: 30$ & 30 & 41.0 & $2 \mathrm{~m}$ & 2 & 0 \\
\hline 28-Jul & $19: 00$ & 30 & 41.5 & $2 m$ & 2 & 0 \\
\hline 28-Jul & $19: 30$ & 30 & 42.0 & $2 \mathrm{~m}$ & 1 & 0 \\
\hline 28-Jul & $20: 00$ & 30 & 42.5 & 2 & 1 & 0 \\
\hline 28-Jul & $20: 30$ & 30 & 43.0 & 2 & 2 & 0 \\
\hline 28-Jul & $21: 00$ & 30 & 43.5 & 2 & 2 & 0 \\
\hline 28-Jul & $21: 30$ & 30 & 44.0 & 2 & 1 & 0 \\
\hline 28-Jul & $22: 00$ & 30 & 44.5 & 2 & 1 & 0 \\
\hline 28-Jul & $22: 30$ & 30 & 45.0 & 2 & 1 & 0 \\
\hline 28-Jul & $23: 00$ & 30 & 45.5 & 2 & 1 & 0 \\
\hline 28-Jul & $23: 30$ & 30 & 46.0 & 1 & 2 & 1 \\
\hline 29-Jul & $0: 00$ & 30 & 46.5 & 1 & 1 & 0 \\
\hline 29-Jul & $0: 30$ & 30 & 47.0 & 1 & 1 & 0 \\
\hline 29-Jul & $1: 00$ & 30 & 47.5 & 1 & 1 & 0 \\
\hline 29-Jul & $1: 30$ & 30 & 48.0 & 2 & 2 & 0 \\
\hline 29-Jul & $2: 00$ & 30 & 48.5 & 2 & 1 & 0 \\
\hline 29-Jul & $2: 30$ & 30 & 49.0 & 2 & 1 & 0 \\
\hline 29-Jul & $3: 00$ & 30 & 49.5 & 1 & 1 & 0 \\
\hline 29-Jul & $3: 30$ & 30 & 50.0 & $1 e$ & $1 \theta$ & $0 \mathrm{e}$ \\
\hline 29-Jul & $4: 00$ & 30 & 50.5 & $2 e$ & $1 e$ & $0 e$ \\
\hline 29-Jul & $4: 30$ & 30 & 51.0 & 2 & 1 & 0 \\
\hline 29-Jul & $5: 00$ & 30 & 51.5 & 2 & 1 & 0 \\
\hline 29-Jul & $5: 30$ & 30 & 52.0 & 2 & 1 & 0 \\
\hline 29-Jul & $6: 00$ & 30 & 52.5 & 1 & 1 & 0 \\
\hline 29-Jul & $6: 30$ & 30 & 53.0 & 2 & 1 & 0 \\
\hline 29-Jul & $7: 00$ & 30 & 53.5 & 1 & 1 & 0 \\
\hline 29-Jul & $7: 30$ & 30 & 54.0 & $1 e$ & $1 e$ & 0 e \\
\hline 29-Jul & $8: 00$ & 30 & 54.5 & $1 \theta$ & $1 e$ & 0 e \\
\hline 29-Jul & $8: 30$ & 30 & 55.0 & $1 \mathrm{e}$ & $1 e$ & 00 \\
\hline 29-Jul & $9: 00$ & 30 & 55.5 & 1 & 1 & 0 \\
\hline 29-Jul & $9: 30$ & 30 & 56.0 & $2 \mathrm{~m}$ & 1 & 0 \\
\hline 29-Jul & $10: 00$ & 30 & 56.5 & 2 & 1 & 0 \\
\hline 29-Jul & $10: 30$ & 30 & 57.0 & $2 \mathrm{~m}$ & 1 & 0 \\
\hline 29-Jul & $11: 00$ & 30 & 57.5 & 2 & 1 & 0 \\
\hline 29-Jul & $11: 30$ & 30 & 58.0 & $1 \mathrm{~m}$ & 1 & 0 \\
\hline 29-Jul & $12: 00$ & 30 & 58.5 & 1 & 1 & 0 \\
\hline 29-Jul & $12: 30$ & 30 & 59.0 & $1 \mathrm{~m}$ & 1 & 0 \\
\hline 29-Jul & $13: 00$ & 30 & 59.5 & 1 & $1 \mathrm{~m}$ & 0 \\
\hline 29-Jul & $13: 30$ & 30 & 60.0 & 1 & $1 \mathrm{~m}$ & 0 \\
\hline 29-Jul & $14: 00$ & 30 & 60.5 & 1 & $1 \mathrm{~m}$ & 0 \\
\hline 29-Jul & $14: 30$ & 30 & 61.0 & 1 & $1 \mathrm{~m}$ & 0 \\
\hline
\end{tabular}


TABLE C.1 (Cont.)

\begin{tabular}{|c|c|c|c|c|c|c|}
\hline \multirow[b]{2}{*}{ Date } & \multirow[b]{2}{*}{ Time } & \multirow[b]{2}{*}{$\begin{array}{c}\text { Time Since } \\
\text { Last Sample } \\
\text { (min.) }\end{array}$} & \multirow[b]{2}{*}{$\begin{array}{l}\text { Elapsed } \\
\text { Time } \\
\text { (hours) }\end{array}$} & \multicolumn{3}{|c|}{ Turbidity (a) } \\
\hline & & & & $\begin{array}{r}\text { Background } \\
\text { (NTU) }\end{array}$ & $\begin{array}{r}600 \mathrm{ft} \\
\text { Downstream } \\
(\mathrm{NTU})\end{array}$ & $\begin{array}{r}\text { Net (b) } \\
\text { (NTU) }\end{array}$ \\
\hline 29-Jul & $15: 00$ & 30 & 61.5 & 1 & $1 \mathrm{~m}$ & 0 \\
\hline 29-Jul & $15: 30$ & 30 & 62.0 & 1 & $1 \mathrm{~m}$ & 0 \\
\hline 29-Jul & $16: 00$ & 30 & 62.5 & 2 & $2 \mathrm{~m}$ & 0 \\
\hline 29-Jul & $16: 30$ & 30 & 63.0 & 2 & $2 \mathrm{~m}$ & 0 \\
\hline 29-Jul & $17: 00$ & 30 & 63.5 & 2 & $2 \mathrm{~m}$ & 0 \\
\hline 29-Jul & $17: 30$ & 30 & 64.0 & 2 & $2 \mathrm{~m}$ & 0 \\
\hline 29-JuIl & $18: 00$ & 30 & 64.5 & 3 & $3 \mathrm{~m}$ & 0 \\
\hline 29-Jul & $18: 30$ & 30 & 65.0 & 3 & $3 \mathrm{~m}$ & 0 \\
\hline 29-Jul & $19: 00$ & 30 & 65.5 & 5 & $5 \mathrm{~m}$ & 0 \\
\hline 29-Jul & $19: 30$ & 30 & 66.0 & 5 & $5 \mathrm{~m}$ & 0 \\
\hline 29-Jul & $20: 00$ & 30 & 66.5 & 5 & $5 \mathrm{~m}$ & 0 \\
\hline 29-Jul & $20: 30$ & 30 & 67.0 & 5 & $5 \mathrm{~m}$ & 0 \\
\hline 29-Jul & $21: 00$ & 30 & 67.5 & 3 & $3 \mathrm{~m}$ & 0 \\
\hline 29-Jul & $21: 20$ & 30 & 68.0 & 3 & $3 \mathrm{~m}$ & 0 \\
\hline 29-Jul & $22: 00$ & 30 & 68.5 & 3 & $3 \mathrm{~m}$ & 0 \\
\hline 29-Jul & $22: 30$ & 30 & 69.0 & 3 & $3 \mathrm{~m}$ & 0 \\
\hline 29-Jul & $23: 00$ & 30 & 69.5 & 1 & $1 \mathrm{~m}$ & 0 \\
\hline 29-Jul & 23:30 & 30 & 70.0 & 1 & $1 \mathrm{~m}$ & 0 \\
\hline 30-Jul & $0: 00$ & 30 & 70.5 & 2 & $2 \mathrm{~m}$ & 0 \\
\hline 30-Jul & $0: 30$ & 30 & 71.0 & 2 & $2 \mathrm{~m}$ & 0 \\
\hline 30-Jul & $1: 00$ & 30 & 71.5 & 2 & $2 \mathrm{~m}$ & 0 \\
\hline 30-Jul & $1: 30$ & 30 & 72.0 & 2 & $2 \mathrm{~m}$ & 0 \\
\hline 30-Jul & $2: 00$ & 30 & 72.5 & 2 & $2 \mathrm{~m}$ & 0 \\
\hline 30-Jul & $2: 30$ & 30 & 73.0 & 2 & $2 \mathrm{~m}$ & 0 \\
\hline 30-Jul & $3: 00$ & 30 & 73.5 & 1 & $1 \mathrm{~m}$ & 0 \\
\hline 30-Jul & $3: 30$ & 30 & 74.0 & 1 & $1 \mathrm{~m}$ & 0 \\
\hline 30-Jul & $4: 00$ & 30 & 74.5 & 2 & $2 \mathrm{~m}$ & 0 \\
\hline 30-Jul & $4: 30$ & 30 & 75.0 & 2 & $2 \mathrm{~m}$ & 0 \\
\hline 30-Jul & $5: 00$ & 30 & 75.5 & 1 & $1 \mathrm{~m}$ & 0 \\
\hline 30-Jul & $5: 30$ & 30 & 76.0 & 1 & $1 \mathrm{~m}$ & 0 \\
\hline 30-Jul & $6: 00$ & 30 & 76.5 & 1 & $1 \mathrm{~m}$ & 0 \\
\hline 30-Jul & $6: 30$ & 30 & 77.0 & 1 & $1 \mathrm{~m}$ & 0 \\
\hline 30-Jul & $7: 00$ & 30 & 77.5 & 1 & $1 \mathrm{~m}$ & 0 \\
\hline 30-Jul & $7: 30$ & 30 & 78.0 & 1 & $1 \mathrm{~m}$ & 0 \\
\hline 30-Jul & $8: 00$ & 30 & 78.5 & $1 \mathrm{~m}$ & $1 \mathrm{~m}$ & 0 \\
\hline 30-Jul & $8: 30$ & 30 & 79.0 & $1 \mathrm{~m}$ & $1 \mathrm{~m}$ & 0 \\
\hline 30-Jul & $9: 00$ & 30 & 79.5 & $1 \mathrm{~m}$ & $1 \mathrm{~m}$ & 0 \\
\hline 30-Jul & $9: 30$ & 30 & 80.0 & $1 \mathrm{~m}$ & $1 \mathrm{~m}$ & 0 \\
\hline 30-Jul & $10: 00$ & 30 & 80.5 & $1 \mathrm{~m}$ & 1 & 0 \\
\hline 30-Jul & $10: 30$ & 30 & 81.0 & $1 \mathrm{~m}$ & $1 e$ & 0 e \\
\hline 30-Jul & $11: 00$ & 30 & 81.5 & 1 & 2 & 1 \\
\hline
\end{tabular}


TABLE C.1 (Cont.)

\begin{tabular}{|c|c|c|c|c|c|c|}
\hline \multirow[b]{2}{*}{ Date } & \multirow[b]{2}{*}{ Time } & \multirow[b]{2}{*}{$\begin{array}{c}\text { Time Since } \\
\text { Last Sample } \\
\text { (min.) }\end{array}$} & \multirow[b]{2}{*}{$\begin{array}{c}\text { Elapsed } \\
\text { Time } \\
\text { (hours) }\end{array}$} & \multicolumn{3}{|c|}{ Turbidity (a) } \\
\hline & & & & $\begin{array}{r}\text { Background } \\
\text { (NTU) }\end{array}$ & $\begin{array}{r}600 \mathrm{ft} \\
\text { Downstream } \\
(\mathrm{NTU})\end{array}$ & $\begin{array}{l}\text { Net (b) } \\
\text { (NTU) }\end{array}$ \\
\hline 30-Jul & $11: 30$ & 30 & 82.0 & 10 & $2 \theta$ & 10 \\
\hline 30-Jul & $12: 00$ & 30 & 82.5 & 1 & 2 & 1 \\
\hline 30-Jul & $12: 30$ & 30 & 83.0 & $1 e$ & $2 \theta$ & $1 e$ \\
\hline 30-Jul & $13: 00$ & 30 & 83.5 & 1 & 1 & 0 \\
\hline 30-Jul & $13: 30$ & 30 & 84.0 & $1 e$ & $1 \theta$ & $0 e$ \\
\hline 30-Jul & $14: 00$ & 30 & 84.5 & 1 & 1 & 0 \\
\hline 30-Jul & $14: 30$ & 30 & 85.0 & $1 e$ & $1 e$ & 0 e \\
\hline 30-Jul & $15: 00$ & 30 & 85.5 & 1 & 1 & 0 \\
\hline 30-Jul & $15: 30$ & 30 & 86.0 & $1 e$ & $1 e$ & 00 \\
\hline 30-Jul & $16: 00$ & 30 & 86.5 & 1 & 8 & 7 \\
\hline 30-Jul & $16: 30$ & 30 & 87.0 & $1 e$ & $8 e$ & $7 e$ \\
\hline 30-Jul & $17: 00$ & 30 & 87.5 & 1 & 2 & 1 \\
\hline 30-Jul & $17: 30$ & 30 & 88.0 & $1 \theta$ & $2 e$ & $1 e$ \\
\hline 30-Jul & $18: 00$ & 30 & 88.5 & 1 & 1 & 0 \\
\hline 30-Jul & $18: 30$ & 30 & 89.0 & $1 e$ & $1 e$ & $0 e$ \\
\hline 30-Jul & $19: 00$ & 30 & 89.5 & 2 & 2 & 0 \\
\hline 30-Jul & $19: 30$ & 30 & 90.0 & $2 e$ & $2 e$ & 0 e \\
\hline 30-Jul & $20: 00$ & 30 & 90.5 & 2 & 1 & 0 \\
\hline 30-Jul & $20: 30$ & 30 & 91.0 & $2 e$ & $1 e$ & $0 \theta$ \\
\hline 30-Jul & $21: 00$ & 30 & 91.5 & 1 & 2 & 1 \\
\hline 30-Jul & $21: 30$ & 30 & 92.0 & $1 e$ & $2 e$ & $1 e$ \\
\hline 30-Jul & $22: 00$ & 30 & 92.5 & 2 & 2 & 0 \\
\hline 30-Jul & $22: 30$ & 30 & 93.0 & $2 \theta$ & $2 \theta$ & 0 e \\
\hline 30-Jul & 23:00 & 30 & 93.5 & 2 & 2 & 0 \\
\hline 30-Jul & $23: 30$ & 30 & 94.0 & $2 \theta$ & $2 \theta$ & $0 \theta$ \\
\hline 31-Jul & $0: 00$ & 30 & 94.5 & 2 & 2 & 0 \\
\hline 31-Jul & $0: 30$ & 30 & 95.0 & $2 e$ & $2 \theta$ & 0 e \\
\hline 31-Jul & $1: 00$ & 30 & 95.5 & 2 & 2 & 0 \\
\hline 31-Jul & $1: 30$ & 30 & 96.0 & $2 e$ & $2 e$ & 0 e \\
\hline
\end{tabular}

(a) $m=$ sample $\mathrm{missed} / \mathrm{value}$ is extrapolated;

$\theta=$ measurements from previous samples are extrapolated for graphing purposes only

(b) Note: If the upstream turbidity reading was higher than the simultaneous downstream reading, net turbidity was equal to 0 . Also, after the upstream sampler was removed, all subsequent net turbidity values were assumed to be zero.

Total Net Downstream Flow-Weighted NTU*hours $=1702$ 
TABLE C.2 Turbidity Measured in the Grab Samples at Crossing \#8

\begin{tabular}{|c|c|c|c|c|c|c|c|}
\hline \multirow[b]{3}{*}{ Date } & \multirow[b]{3}{*}{ Time } & \multicolumn{6}{|c|}{ Turbidity } \\
\hline & & \multicolumn{3}{|c|}{$600 \mathrm{ft}$ Downstream } & \multicolumn{3}{|c|}{$1200 \mathrm{ft}$ Downstream } \\
\hline & & Left & $\begin{array}{l}\text { Center } \\
\text { (NTU) }\end{array}$ & Right & Left & $\begin{array}{l}\text { Center } \\
\text { (NTU) }\end{array}$ & Right \\
\hline$<7-J u l$ & 1200 & 3.7 & 6.5 & 23.6 & - & . & - \\
\hline $27-J u l$ & 1300 & 30.5 & 42.0 & 114.4 & - & - & - \\
\hline 27-Jul & 1400 & - & - & - & 66.0 & 148.0 & 260.0 \\
\hline 27-Jul & 1500 & 35.0 & 44.0 & 106.0 & - & - & - \\
\hline 27 -Jul & 1600 & - & - & - & 72.0 & 146.0 & 232.0 \\
\hline 27-Jul & 1700 & 46.0 & 52.5 & 134.0 & - & - & - \\
\hline 27-Jul & 1800 & - & - & - & 91.0 & 128.0 & 248.0 \\
\hline
\end{tabular}


TABLE C.3 Turbidity Generated by Crossing \#6

\begin{tabular}{|c|c|c|c|c|c|c|c|}
\hline \multirow[b]{2}{*}{ Date } & \multirow[b]{2}{*}{ Time } & \multirow[b]{2}{*}{$\begin{array}{l}\text { Time Since } \\
\text { Last Sample } \\
(\min .)\end{array}$} & \multirow[b]{2}{*}{$\begin{array}{l}\text { Elapsed } \\
\text { Time } \\
\text { (hours) }\end{array}$} & \multicolumn{4}{|c|}{ Turbidity (a) } \\
\hline & & & & $\begin{array}{r}\text { Background } \\
\text { (NTU) }\end{array}$ & $\begin{array}{r}600 \mathrm{ft} \\
\text { Downstream } \\
(\mathrm{NTU})\end{array}$ & $\begin{array}{l}\text { Net (b) } \\
\text { (NTU) }\end{array}$ & $\begin{array}{r}\text { At } \\
\text { Crossing \#8 } \\
(\text { NTU) }\end{array}$ \\
\hline 31-Jul & $2: 00$ & 0 & 0.0 & 1 & 2 & 1 & 1 \\
\hline 31-Jul & $2: 30$ & 30 & 0.5 & 1 & 2 & 1 & $1 \theta$ \\
\hline 31-Jul & $3: 00$ & 30 & 1.0 & 1 & 1 & 0 & 7 \\
\hline 31-Jul & $3: 30$ & 30 & 1.5 & 1 & 5 & 4 & $7 \theta$ \\
\hline 31-Jul & $4: 00$ & 30 & 2.0 & 1 & 2 & 1 & 4 \\
\hline 31-Jul & $4: 30$ & 30 & 2.5 & 1 & 2 & 1 & $4 \theta$ \\
\hline 31-Jul & $5: 00$ & 30 & 3.0 & 1 & 6 & 5 & 9 \\
\hline 31-Jul & $5: 30$ & 30 & 3.5 & 1 & 196 & 195 & $9 \theta$ \\
\hline 31-Jul & $6: 00$ & 30 & 4.0 & 1 & 345 & 344 & 1 \\
\hline 31-Jul & $6: 30$ & 30 & 4.5 & 1 & 744 & 743 & $1 \theta$ \\
\hline 31-Jul & $7: 00$ & 30 & 5.0 & 1 & 504 & 503 & 3 \\
\hline 31-Jul & $7: 30$ & 30 & 5.5 & 1 & 435 & 434 & $3 e$ \\
\hline 31-Jul & $8: 00$ & 30 & 6.0 & 1 & 163 & 162 & 1 \\
\hline 31-Jul & $8: 30$ & 30 & 6.5 & 1 & 146 & 145 & $1 \theta$ \\
\hline 31-Jul & $9: 00$ & 30 & 7.0 & 1 & 103 & 102 & 1 \\
\hline 31-Jul & $9: 30$ & 30 & 7.5 & 1 & 57 & 56 & $1 \theta$ \\
\hline 31-Jul & $10: 00$ & 30 & 8.0 & 1 & 69 & 68 & 33 \\
\hline 31-Jul & $10: 30$ & 30 & 8.5 & 1 & 53 & 52 & $33 \theta$ \\
\hline 31-Jul & $11: 00$ & 30 & 9.0 & 1 & 54 & 53 & 117 \\
\hline 31-Jul & $11: 30$ & 30 & 9.5 & 1 & 45 & 44 & $117 \theta$ \\
\hline 31-Jul & $12: 00$ & 30 & 10.0 & 1 & 20 & 19 & 175 \\
\hline 31-Jul & $12: 30$ & 30 & 10.5 & 1 & 24 & 23 & $175 \mathrm{e}$ \\
\hline 31-Jul & $13: 00$ & 30 & 11.0 & 2 & 15 & 13 & 177 \\
\hline 31-Jul & $13: 30$ & 30 & 11.5 & 2 & 30 & 28 & $177 e$ \\
\hline 31-Jul & $14: 00$ & 30 & 12.0 & 2 & 9 & 7 & 154 \\
\hline 31-Jul & $14: 30$ & 30 & 12.5 & 3 & 10 & 7 & 154 e \\
\hline 31-Jul & $15: 00$ & 30 & 13.0 & 2 & 8 & 6 & 129 \\
\hline 31-Jul & $15: 30$ & 30 & 13.5 & 1 & 7 & 6 & $129 \theta$ \\
\hline 31-Jul & $16: 00$ & 30 & 14.0 & 2 & 8 & 6 & 170 \\
\hline 31-Jul & $16: 30$ & 30 & 14.5 & 2 & 7 & 5 & $170 \theta$ \\
\hline 31-Jul & $17: 00$ & 30 & 15.0 & 3 & 9 & 6 & 163 \\
\hline 31-Jul & $17: 30$ & 30 & 15.5 & 2 & 10 & 8 & $163 \theta$ \\
\hline 31-Jul & $18: 00$ & 30 & 16.0 & 1 & 10 & 9 & 131 \\
\hline 31-Jul & $18: 30$ & 30 & 16.5 & 2 & 7 & 5 & $131 \theta$ \\
\hline 31-Jul & $19: 00$ & 30 & 17.0 & 2 & 7 & 5 & 104 \\
\hline 31-Jul & $19: 30$ & 30 & 17.5 & 2 & 3 & 1 & $104 \theta$ \\
\hline 31-Jul & $20: 00$ & 30 & 18.0 & 3 & 2 & 0 & 120 \\
\hline 31-Jul & $20: 30$ & 30 & 18.5 & 4 & 2 & 0 & $120 \theta$ \\
\hline 31-Jul & $21: 00$ & 30 & 19.0 & 1 & 2 & 1 & 78 \\
\hline 31-Jul & $21: 30$ & 30 & 19.5 & 2 & 10 & 8 & $78 \mathrm{e}$ \\
\hline 31-Jul & $22: 00$ & 30 & 20.0 & 1 & 2 & 1 & 53 \\
\hline 31-Jul & $22: 30$ & 30 & 20.5 & 2 & 2 & 0 & $53 \theta$ \\
\hline
\end{tabular}


TABLE C.3 (Cont.)

\begin{tabular}{|c|c|c|c|c|c|c|c|c|}
\hline \multirow[b]{2}{*}{ Date } & \multirow[b]{2}{*}{ Time } & \multirow[b]{2}{*}{$\begin{array}{l}\text { Time Since } \\
\text { Last Sample } \\
\text { (min.) }\end{array}$} & \multirow[b]{2}{*}{$\begin{array}{l}\text { Elapsed } \\
\text { Time } \\
\text { (hours) }\end{array}$} & \multicolumn{5}{|c|}{ Turbidity (a) } \\
\hline & & & & $\begin{array}{r}\text { Background } \\
\text { (NTU) }\end{array}$ & & $\begin{array}{r}600 \mathrm{ft} \\
\text { Downstream } \\
\text { (NTU) }\end{array}$ & $\begin{array}{r}\text { Net (b) } \\
\text { (NTU) }\end{array}$ & $\begin{array}{c}\text { At } \\
\text { Crossing \#8 } \\
\text { (NTU) }\end{array}$ \\
\hline 31-Jul & $23: 00$ & 30 & 21.0 & 2 & & 2 & 0 & 82 \\
\hline 31-Jul & $23: 30$ & 30 & 21.5 & 2 & & 10 & 8 & $82 \theta$ \\
\hline 1.Aug & $0: 00$ & 30 & 22.0 & 2 & & 2 & 0 & 56 \\
\hline 1-Aug & $0: 30$ & 30 & 22.5 & 1 & & 2 & 1 & $56 \theta$ \\
\hline 1.Aug & $1: 00$ & 30 & 23.0 & 1 & & 1 & 0 & 37 \\
\hline 1-Aug & $1: 30$ & 30 & 23.5 & 2 & & 1 & 0 & $37 e$ \\
\hline 1-Aug & $2: 00$ & 30 & 24.0 & 1 & & 1 & 0 & 21 \\
\hline 1.Aug & $2: 30$ & 30 & 24.5 & 1 & & 1 & 0 & $21 \theta$ \\
\hline 1-Aug & $3: 00$ & 30 & 25.0 & 1 & & 1 & 0 & 20 \\
\hline 1-Aug & $3: 30$ & 30 & 25.5 & 1 & & 1 & 0 & $20 \theta$ \\
\hline 1-Aug & $4: 00$ & 30 & 26.0 & 2 & & 2 & 0 & 11 \\
\hline 1-Aug & $4: 30$ & 30 & 26.5 & 1 & & 1 & 0 & $11 \theta$ \\
\hline 1.Aug & $5: 00$ & 30 & 27.0 & 1 & & 2 & 1 & 10 \\
\hline 1.Aug & $5: 30$ & 30 & 27.5 & 1 & & 1 & 0 & $10 \theta$ \\
\hline 1-Aug & $6: 00$ & 30 & 28.0 & 1 & & 1 & 0 & 5 \\
\hline 1-Aug & $6: 30$ & 30 & 28.5 & 2. & & 2 & 0 & $5 \theta$ \\
\hline 1.Aug & $7: 00$ & 30 & 29.0 & 1 & & 2 & 1 & 5 \\
\hline 1-Aug & $7: 30$ & 30 & 29.5 & 1 & & 2 & 1 & $5 \theta$ \\
\hline 1-Aug & $8: 00$ & 30 & 30.0 & 1 & & 1 & 0 & 4 \\
\hline 1.Aug & $8: 30$ & 30 & 30.5 & 2 & & $?$ & 0 & $4 \theta$ \\
\hline 1:Aug & $9: 00$ & 30 & 31.0 & 2 & $\theta$ & 2 & 0 & 3 \\
\hline 1-Aug & $9: 30$ & 30 & 31.5 & 2 & $\theta$ & 1 & 0 & $3 \theta$ \\
\hline 1-Aug & $10: 00$ & 30 & 32.0 & 2 & $\theta$ & 7 & 5 & 4 \\
\hline 1-Aug & $10: 30$ & 30 & 32.5 & 2 & $\theta$ & 13 & 11 & $4 \theta$ \\
\hline 1.Aug & $11: 00$ & 30 & 33.0 & 2 & $\theta$ & 28 & 26 & 3 \\
\hline 1-Aug & $11: 30$ & 30 & 33.5 & 2 & $\theta$ & 7 & 5 & $3 \theta$ \\
\hline 1-Aug & $12: 00$ & 30 & 34.0 & 2 & $\theta$ & 73 & 71 & 5 \\
\hline 1-Aug & $12: 30$ & 30 & 34.5 & 2 & $\theta$ & 23 & 21 & $5 \theta$ \\
\hline 1-Aug & $13: 00$ & 30 & 35.0 & 2 & $\theta$ & 173 & 171 & 7 \\
\hline 1-Aug & $13: 30$ & 30 & 35.5 & 2 & $\theta$ & 227 & 225 & $7 \theta$ \\
\hline 1-Aug & $14: 00$ & 30 & 36.0 & 2 & $\theta$ & 130 & 128 & 7 \\
\hline 1.Aug & $14: 30$ & 30 & 36.5 & 2 & $\theta$ & 84 & 82 & $7 \theta$ \\
\hline 1-Aug & $15: 00$ & 30 & 37.0 & 2 & $\theta$ & 55 & 53 & 16 \\
\hline 1-Aug & $15: 30$ & 30 & 37.5 & 2 & $\theta$ & 12 & 10 & $16 \theta$ \\
\hline 1.Aug & $16: 00$ & 30 & 38.0 & 2 & $\theta$ & 5 & 3 & 49 \\
\hline 1-Aug & $16: 30$ & 30 & 38.5 & 2 & $\theta$ & 6 & 4 & $49 \theta$ \\
\hline 1.Aug & $17: 00$ & 30 & 39.0 & 2 & $\theta$ & 11 & 9 & 66 \\
\hline 1.Aug & $17: 30$ & 30 & $3 y .5$ & 2 & $\theta$ & 5 & 3 & $66 \theta$ \\
\hline 1.Aug & $18: 00$ & 30 & 40.0 & 2 & $\theta$ & 3 & 1 & 75 \\
\hline 1.Aug & $18: 30$ & 30 & 40.5 & 2 & $\theta$ & 1 & 0 & $75 e$ \\
\hline 1-Aug & $19: 00$ & 30 & 41.0 & 2 & $\theta$ & 2 & 0 & 166 \\
\hline 1-Aug & $19: 30$ & 30 & 41.5 & 2 & $\theta$ & 2 & 0 & $166 e$ \\
\hline
\end{tabular}


TABLE C.3 (Cont.)

Turbidity (a)

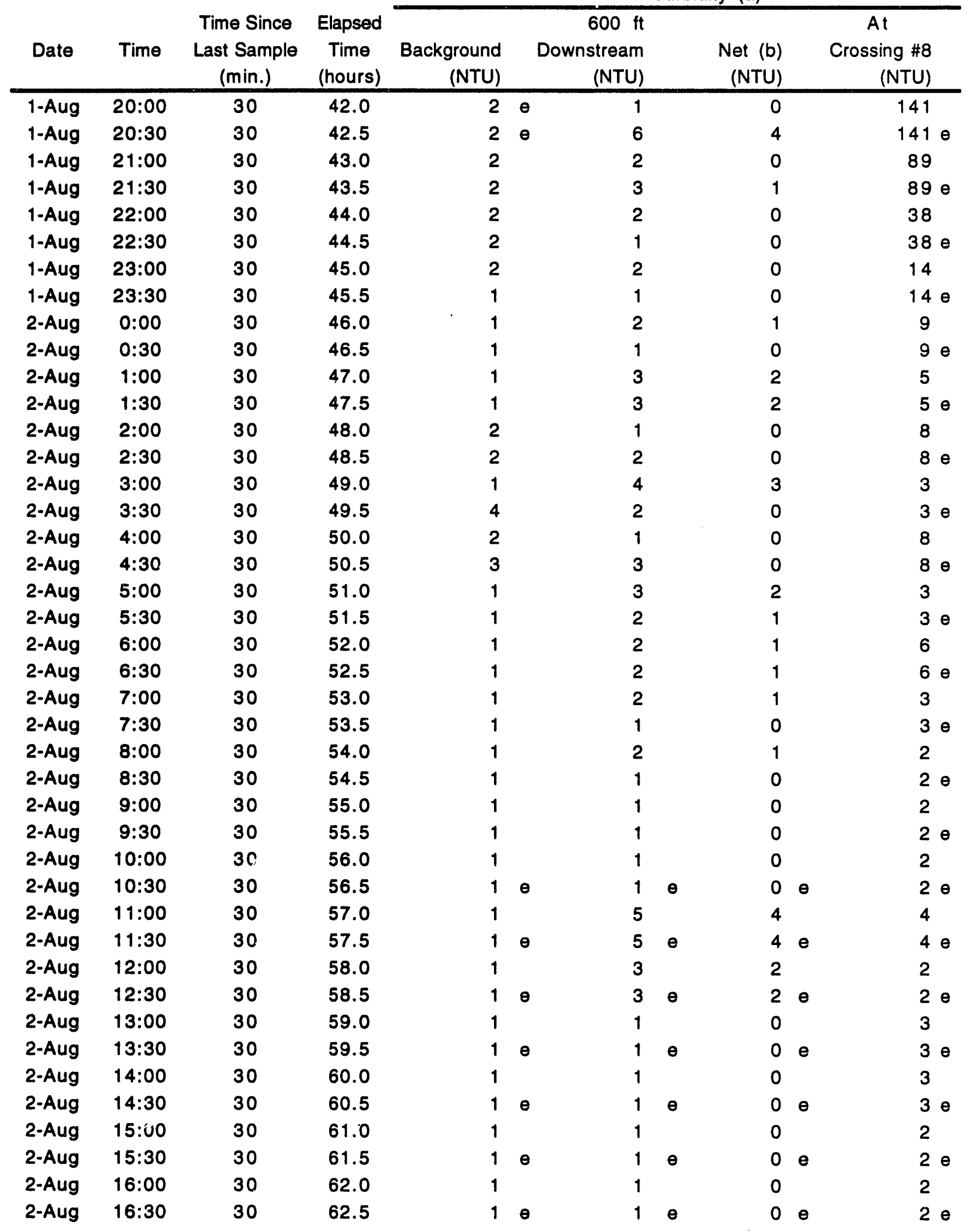


TABLE C.3 (Cont.)

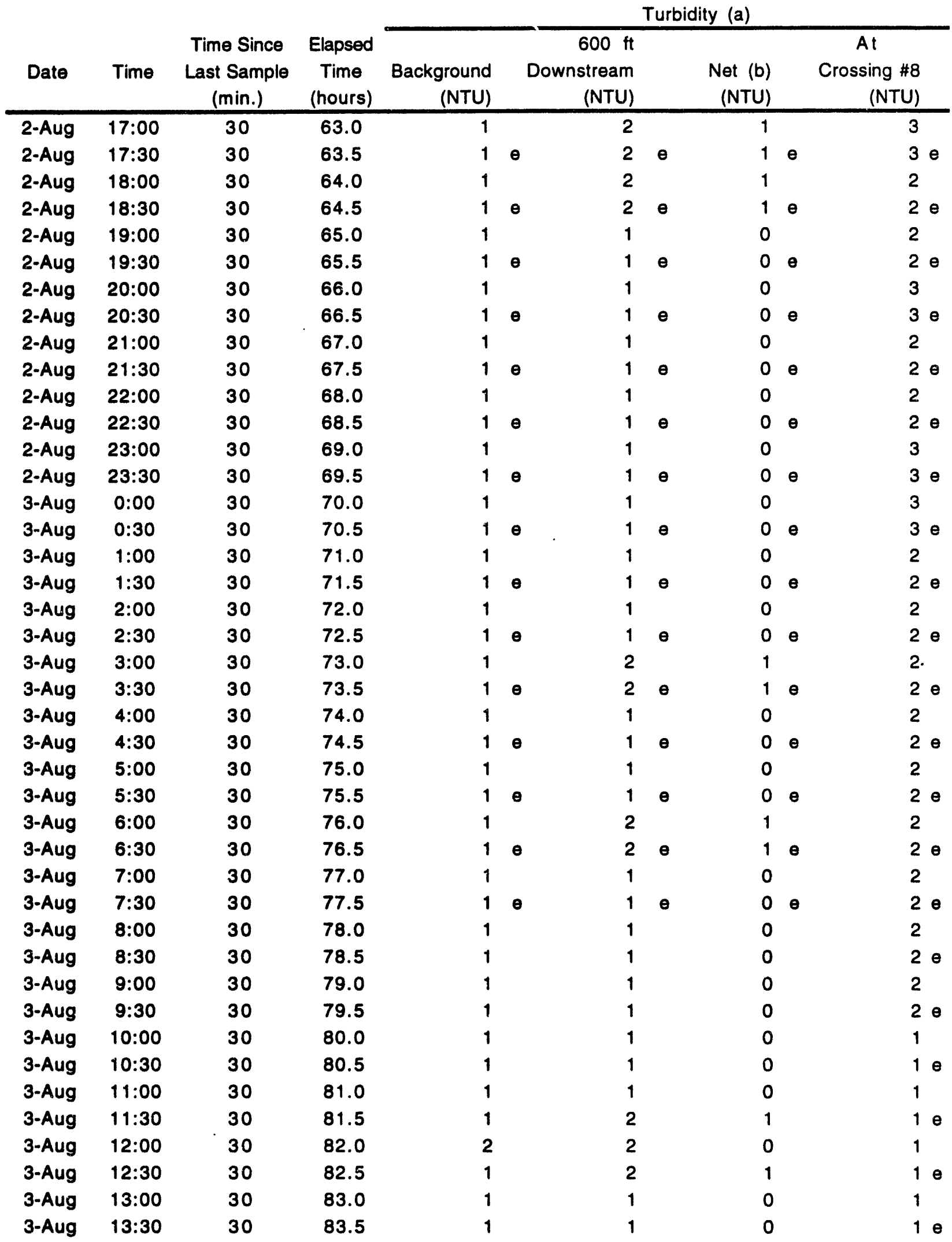


TABLE C.3 (Cont.)

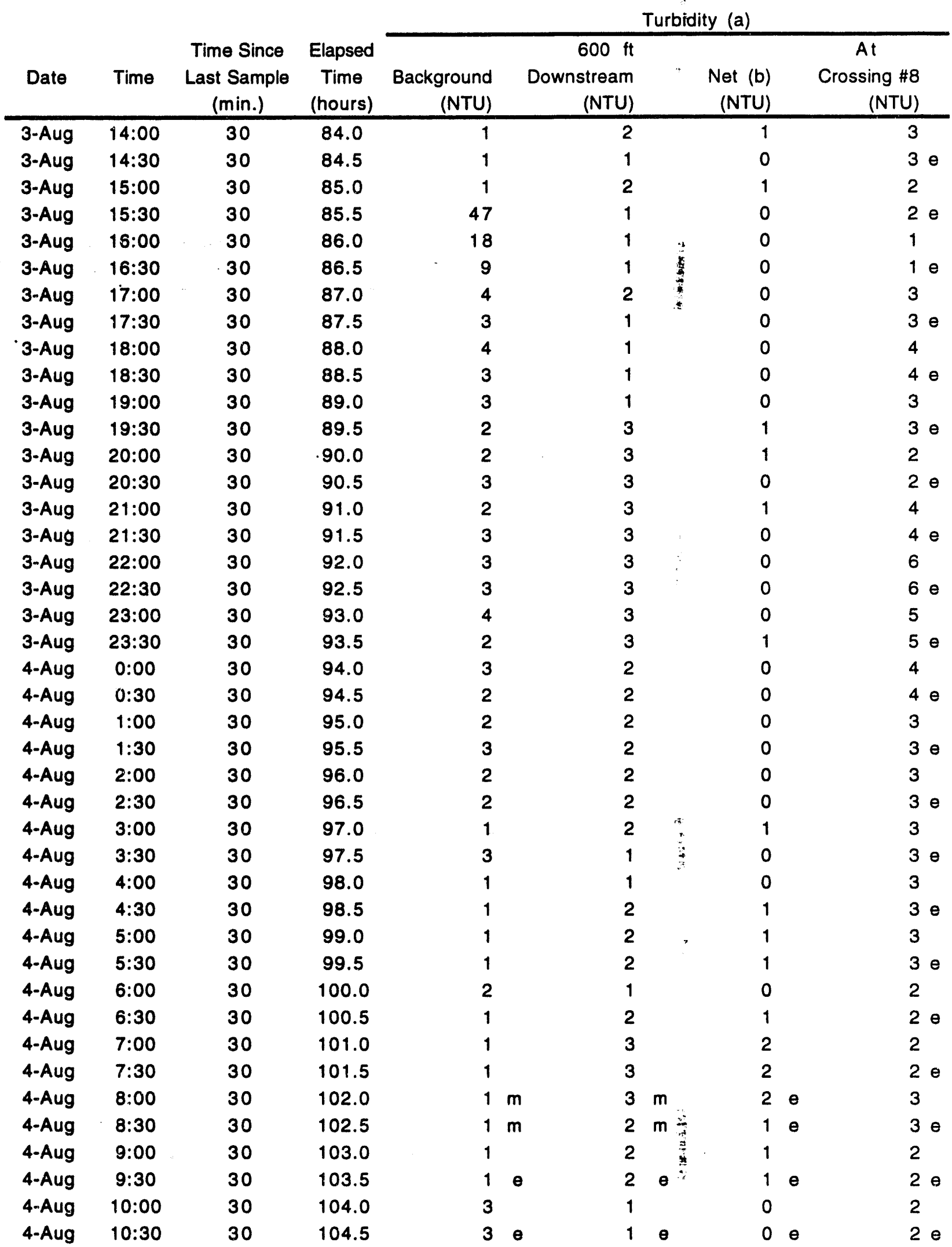


TABLE C.3 (Cont.)

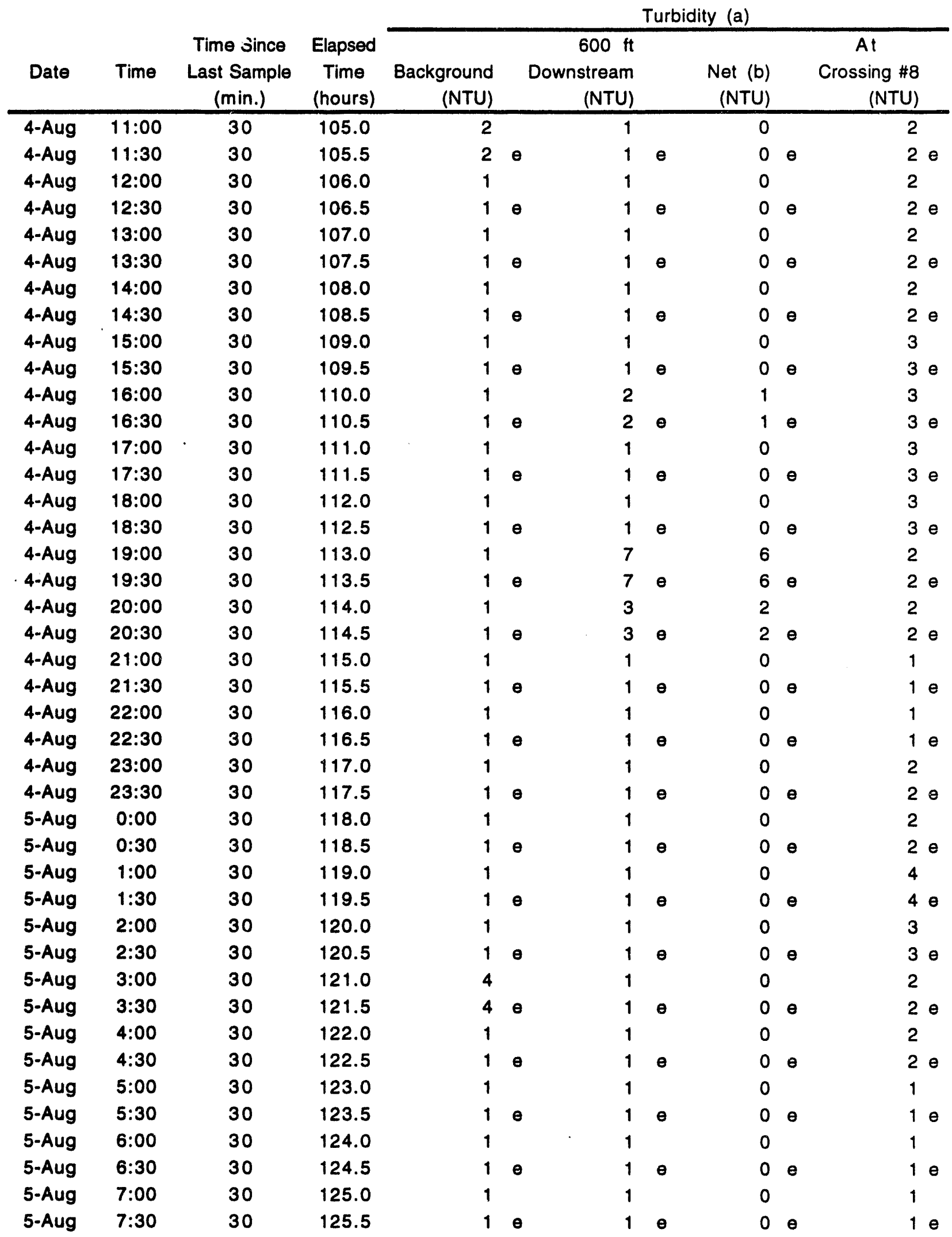


TABLE C.3 (Cont.)

urbidity (a)

\begin{tabular}{|c|c|c|c|c|c|c|c|c|c|}
\hline Date & Time & $\begin{array}{c}\text { Time Since } \\
\text { Last Sample } \\
\text { (min.) }\end{array}$ & $\begin{array}{l}\text { Elapsed } \\
\text { Time } \\
\text { (hours) }\end{array}$ & $\begin{array}{r}\text { Background } \\
\text { (NTU) }\end{array}$ & & & $\begin{array}{r}\text { Net (b) } \\
\text { (NTU) }\end{array}$ & & $\begin{array}{c}\text { At } \\
\text { Crossing \#8 } \\
\text { (NTU) }\end{array}$ \\
\hline 5-Aug & $8: 00$ & 30 & 126.0 & 1 & & & 1 & & 1 \\
\hline 5-Aug & $8: 30$ & 30 & 126.5 & 1 & $\theta$ & $\theta$ & 1 & $e$ & $1 e$ \\
\hline 5-Aug & $9: 00$ & 30 & 127.0 & 1 & & & 0 & & 1 \\
\hline 5-Aug & $9: 30$ & 30 & 127.5 & 1 & $\theta$ & e & 0 & e & $1 e$ \\
\hline 5-Aug & $10: 00$ & 30 & 128.0 & 1 & & & 1 & & 2 \\
\hline 5-Aug & $10: 30$ & 30 & 128.5 & 1 & $\theta$ & $\theta$ & 1 & $e$ & $2 \theta$ \\
\hline 5-Aug & $11: 00$ & 30 & 129.0 & 1 & & & 0 & & 1 \\
\hline 5-Aug & $11: 30$ & 30 & 129.5 & 1 & $\theta$ & $\theta$ & 0 & $\theta$ & $1 e$ \\
\hline 5-Aug & $12: 00$ & 30 & 130.0 & 2 & & & 0 & & 2 \\
\hline 5-Aug & $12: 30$ & 30 & 130.5 & 2 & $e$ & $\theta$ & 0 & $\theta$ & $2 e$ \\
\hline 5-Aug & $13: 00$ & 30 & 131.0 & 1 & & & 0 & & 1 \\
\hline 5-Aug & $13: 30$ & 30 & 131.5 & 1 & $\theta$ & $\theta$ & 0 & $\theta$ & $1 e$ \\
\hline 5-Aug & $14: 00$ & 30 & 132.0 & 1 & & & 0 & & 1 \\
\hline 5-Aug & $14: 30$ & 30 & 132.5 & 1 & $e$ & $e$ & 0 & $\theta$ & $1 \mathrm{e}$ \\
\hline 5-Aug & $15: 00$ & 30 & 133.0 & 1 & & & 0 & & 3 \\
\hline 5-Aug & $15: 30$ & 30 & 133.5 & 1 & $\theta$ & $\theta$ & 0 & $\theta$ & $3 e$ \\
\hline 5-Aug & $16: 00$ & 30 & 134.0 & 1 & & & 1 & & 1 \\
\hline 5-Aug & $16: 30$ & 30 & 134.5 & 1 & $\theta$ & $\theta$ & 1 & e & $1 e$ \\
\hline 5-Aug & $17: 00$ & 30 & 135.0 & 1 & & & 0 & & 1 \\
\hline 5-Aug & $17: 30$ & 30 & 135.5 & 1 & $\theta$ & e & 0 & $\theta$ & $1 e$ \\
\hline 5-Aug & $18: 00$ & 30 & 136.0 & 1. & & & 0 & & 1 \\
\hline 5-Aug & $18: 30$ & 30 & 136.5 & 1 & $\theta$ & $\theta$ & 0 & $\theta$ & $1 e$ \\
\hline 5-Aug & $19: 00$ & 30 & 137.0 & 1 & & & 1 & & 1 \\
\hline 5-Aug & $19: 30$ & 30 & 137.5 & 1 & $\theta$ & $\theta$ & 1 & $\theta$ & $1 e$ \\
\hline 5-Aug & 20:00 & 30 & 138.0 & 1 & & & 0 & & 2 \\
\hline 5-Aug & $20: 30$ & 30 & 138.5 & 1 & $\theta$ & $\theta$ & 0 & $\theta$ & $2 e$ \\
\hline 5-Aug & 21:00 & 30 & 139.0 & 1 & & & 1 & & 2 \\
\hline 5-Aug & $21: 30$ & 30 & 139.5 & 1 & $\theta$ & $e$ & 1 & e & $2 \theta$ \\
\hline 5-Aug & 22:00 & 30 & 140.0 & 1 & & & 0 & & 1 \\
\hline 5-Aug & $22: 30$ & 30 & 140.5 & 1 & $e$ & $e$ & 0 & e & $1 e$ \\
\hline 5-Aug & 23:00 & 30 & 141.0 & 1 & & & 1 & & 1 \\
\hline 5-Aug & 23:30 & 30 & 141.5 & 1 & $e$ & $\theta$ & 1 & $\theta$ & $1 \epsilon$ \\
\hline 6-Aug & $0: 00$ & 30 & 142.0 & 1 & & & 0 & & 1 \\
\hline 6-Aug & $0: 30$ & 30 & 142.5 & 1 & $\theta$ & $\theta$ & 0 & $\theta$ & $1 e$ \\
\hline 6-Aug & $1: 00$ & 30 & 143.0 & 1 & & & 0 & & 2 \\
\hline 6-Aug & $1: 30$ & 30 & 143.5 & 1 & $\theta$ & $\theta$ & 0 & $\theta$ & $2 \epsilon$ \\
\hline 6-Aug & $2: 00$ & 30 & 144.0 & 1 & & & 0 & & 1 \\
\hline 6-Aug & $2: 30$ & 30 & 144.5 & 1 & $\theta$ & $\theta$ & 0 & $\theta$ & $1 \epsilon$ \\
\hline 6-Aug & 3:00 & 30 & 145.0 & 1 & & & 0 & & 1 \\
\hline 6-Aug & 3:30 & 30 & 145.5 & 1 & $e$ & $\theta$ & 0 & $\theta$ & $1 \epsilon$ \\
\hline 6-Aug & 4:00 & 30 & 146.0 & 1 & & & 0 & & 2 \\
\hline 6-Aug & $4: 30$ & 30 & 146.5 & 1 & $\theta$ & $\theta$ & 0 & $e$ & $2 \epsilon$ \\
\hline
\end{tabular}


TABLE C.3 (Cont.)

\begin{tabular}{|c|c|c|c|c|c|c|c|c|c|}
\hline \multirow[b]{2}{*}{ Date } & \multirow[b]{2}{*}{ Time } & \multirow[b]{2}{*}{$\begin{array}{l}\text { Time Since } \\
\text { Last Sample } \\
\text { (min.) }\end{array}$} & \multirow[b]{2}{*}{$\begin{array}{c}\text { Elapsed } \\
\text { Time } \\
\text { (hours) }\end{array}$} & \multicolumn{6}{|c|}{ Turbidity (a) } \\
\hline & & & & $\begin{array}{r}\text { Background } \\
\text { (NTU) }\end{array}$ & & & $\begin{array}{r}\text { Net (b) } \\
\text { (NTU) }\end{array}$ & & $\begin{array}{c}\text { At } \\
\text { Crossing \#8 } \\
\text { (NTU) } \\
\end{array}$ \\
\hline 6-Aug & $5: 00$ & 30 & 147.0 & 1 & & & 0 & & 2 \\
\hline 6-Aug & $5: 30$ & 30 & 147.5 & 1 & $\theta$ & $\theta$ & 0 & $\theta$ & $2 e$ \\
\hline 6-Aug & $6: 00$ & 30 & 148.0 & 1 & & & 0 & & 1 \\
\hline 6-Aug & $6: 30$ & 30 & 148.5 & 1 & $\theta$ & $\theta$ & 0 & $e$ & $1 e$ \\
\hline 6-Aug & 7:00 & 30 & 149.0 & 1 & & & 1 & & 2 \\
\hline 6-Aug & $7: 30$ & 30 & 149.5 & 1 & $\theta$ & $\theta$ & 1 & $\theta$ & $2 e$ \\
\hline 6-Aug & 8:00 & 30 & 150.0 & 1 & & & 0 & & 1 \\
\hline 6-Aug & $8: 30$ & 30 & 150.5 & 1 & $\theta$ & $\theta$ & 0 & $\theta$ & $1 e$ \\
\hline 6-Aug & 9:00 & 30 & 151.0 & 1 & & & 0 & & 1 \\
\hline 6-Aug & 9:30 & 30 & 151.5 & 1 & $\theta$ & $\theta$ & 0 & $\theta$ & $1 e$ \\
\hline 6-Aug & $10: 00$ & 30 & 152.0 & 1 & & & 0 & & 1 \\
\hline 6-Aug & $10: 30$ & 30 & 152.5 & 1 & $\theta$ & $\theta$ & 0 & $\theta$ & 10 \\
\hline 6-Aug & $11: 00$ & 30 & 153.0 & 1 & & & 0 & & 1 \\
\hline 6-Aug & $11: 30$ & 30 & 153.5 & 1 & $\theta$ & $\boldsymbol{e}$ & 0 & $\theta$ & $1 e$ \\
\hline 6-Aug & $12: 00$ & 30 & 154.0 & 1 & & & 0 & & 2 \\
\hline 6-Aug & $12: 30$ & 30 & 154.5 & 1 & $\theta$ & $\theta$ & 0 & $\theta$ & $2 \theta$ \\
\hline 6-Aug & $13: 00$ & 30 & 155.0 & 1 & & & 0 & & 2 \\
\hline 6-Aug & 13:30 & 30 & 155.5 & 1 & $\theta$ & $e$ & 0 & $\theta$ & $2 e$ \\
\hline 6-Aug & $14: 00$ & 30 & 156.0 & 1 & & & 0 & & 1 \\
\hline 6-Aug & $14: 30$ & 30 & 156.5 & 1 & $\theta$ & $\theta$ & 0 & $\theta$ & $1 e$ \\
\hline 6-Aug & $15: 00$ & 30 & 157.0 & 1 & & & 0 & & 1 \\
\hline 6-Aug & $15: 30$ & 30 & 157.5 & 1 & $\theta$ & $\theta$ & 0 & $\theta$ & $1 e$ \\
\hline 6-Aug & $16: 00$ & 30 & 158.0 & 1 & & & 0 & & 1 \\
\hline 6-Aug & $16: 30$ & 30 & 158.5 & 1 & $\theta$ & $\theta$ & 0 & $\theta$ & $1 e$ \\
\hline 6-Aug & $17: 00$ & 30 & 159.0 & 1 & & & 0 & & 1 \\
\hline 6-Aug & $17: 30$ & 30 & 159.5 & 1 & $e$ & e & 0 & $\theta$ & $1 e$ \\
\hline 6-Aug & $18: 00$ & 30 & 160.0 & 1 & & & 0 & & 1 \\
\hline 6-Aug & $18: 30$ & 30 & 160.5 & 1 & $\theta$ & $\theta$ & 0 & $\theta$ & $1 \theta$ \\
\hline 6-Aug & 19:00 & 30 & 161.0 & 1 & & & 0 & & 2 \\
\hline 6-Aug & $19: 30$ & 30 & 161.5 & 1 & $\theta$ & $\theta$ & 0 & $\theta$ & $2 \theta$ \\
\hline 6-Aug & 20:00 & 30 & 162.0 & 1 & & & 0 & & 2 \\
\hline 6-Aug & $20: 30$ & 30 & 162.5 & 1 & $\theta$ & $e$ & 0 & $\theta$ & $2 \theta$ \\
\hline 6-Aug & 21:00 & 30 & 163.0 & 1 & & & 0 & & 1 \\
\hline 6-Aug & 21:30 & 30 & 163.5 & 1 & $\theta$ & $e$ & 0 & $e$ & $1 e$ \\
\hline 6-Aug & 22:00 & 30 & 164.0 & 1 & & & 0 & & 2 \\
\hline 6-Aug & 22:30 & 30 & 164.5 & 1 & $\theta$ & $\theta$ & 0 & e & $2 e$ \\
\hline 6-Aug & 23:00 & 30 & 165.0 & 1 & & & 0 & & 1 \\
\hline 6-Aug & 23:30 & 30 & 165.5 & 1 & $\theta$ & $e$ & 0 & $\theta$ & $1 e$ \\
\hline 7-Aug & $0: 00$ & 30 & 166.0 & 1 & & & 0 & & 2 \\
\hline 7-Aug & $0: 30$ & 30 & 166.5 & 1 & $\theta$ & $\theta$ & 0 & e & $2 e$ \\
\hline 7-Aug & $1: 00$ & 30 & 167.0 & 1 & & & 0 & & 1 \\
\hline 7-Aug & $1: 30$ & 30 & 167.5 & 1 & $\theta$ & $\theta$ & 0 & $\theta$ & $1 e$ \\
\hline
\end{tabular}


TABLE C.3 (Cont.)

\begin{tabular}{|c|c|c|c|c|c|c|c|c|c|}
\hline \multirow[b]{2}{*}{ Date } & \multirow[b]{2}{*}{ Time } & \multirow[b]{2}{*}{$\begin{array}{c}\text { Time Since } \\
\text { Last Sample } \\
\text { (min.) }\end{array}$} & \multirow[b]{2}{*}{$\begin{array}{c}\text { Elapsed } \\
\text { Time } \\
\text { (hours) }\end{array}$} & \multicolumn{6}{|c|}{ Turbidity (a) } \\
\hline & & & & $\begin{array}{r}\text { Background } \\
\text { (NTU) }\end{array}$ & & & $\begin{array}{r}\text { Net (b) } \\
\text { (NTU) }\end{array}$ & & $\begin{array}{c}\text { At } \\
\text { Crossing \#8 } \\
\text { (NTU) }\end{array}$ \\
\hline 7-Aug & $2: 00$ & 30 & 168.0 & 1 & & & 0 & & 1 \\
\hline 7-Aug & $2: 30$ & 30 & 168.5 & 1 & $\boldsymbol{\theta}$ & e & 0 & $e$ & $1 e$ \\
\hline 7-Aug & $3: 00$ & 30 & 169.0 & 1 & & & 0 & & 1 \\
\hline 7-Aug & $3: 30$ & 30 & 169.5 & 1 & $\boldsymbol{\theta}$ & e & 0 & $\theta$ & $1 e$ \\
\hline 7-Aug & $4: 00$ & 30 & 170.0 & 1 & & & 0 & & 2 \\
\hline 7-Aug & $4: 30$ & 30 & 170.5 & 1 & $\theta$ & $\boldsymbol{\theta}$ & 0 & $e$ & $2 \theta$ \\
\hline 7-Aug & $5: 00$ & 30 & 171.0 & 1 & & & 0 & & 1 \\
\hline 7-Aug & $5: 30$ & 30 & 171.5 & 1 & $\theta$ & $\theta$ & 0 & $e$ & $1 e$ \\
\hline 7-Aug & $6: 00$ & 30 & 172.0 & 1 & & & 0 & & 1 \\
\hline 7-Aug & $6: 30$ & 30 & 172.5 & 1 & $\theta$ & $\theta$ & 0 & $\theta$ & $1 e$ \\
\hline 7-Aug & $7: 00$ & 30 & 173.0 & 1 & & & 0 & & 1 \\
\hline 7-Aug & $7: 30$ & 30 & 173.5 & 1 & $e$ & $\theta$ & 0 & e & $1 e$ \\
\hline 7-Aug & $8: 00$ & 30 & 174.0 & 1 & $\mathrm{~m}$ & $m$ & 0 & $e$ & 1 \\
\hline 7-Aug & $8: 30$ & 30 & 174.5 & 1 & $\mathrm{~m}$ & $\mathrm{~m}$ & 0 & $e$ & $1 e$ \\
\hline 7-Aug & $9: 00$ & 30 & 175.0 & 1 & & & 0 & & 1 \\
\hline 7-Aug & $9: 30$ & 30 & 175.5 & 1 & $\theta$ & $e$ & 0 & $e$ & $1 e$ \\
\hline 7-Aug & $10: 00$ & 30 & 176.0 & 1 & & & 1 & & 1 \\
\hline 7-Aug & $10: 30$ & 30 & 176.5 & 1 & $\theta$ & $\theta$ & 1 & $e$ & $1 e$ \\
\hline 7-Aug & $11: 00$ & 30 & 177.0 & 1 & & & 0 & & 1 \\
\hline 7-Aug & $11: 30$ & 30 & 177.5 & 1 & $e$ & $e$ & 0 & $e$ & $1 \theta$ \\
\hline 7-Aug & $12: 00$ & 30 & 178.0 & 1 & & & 0 & & 1 \\
\hline 7-Aug & $12: 30$ & 30 & 178.5 & 1 & $\theta$ & $e$ & 0 & $e$ & $1 \theta$ \\
\hline 7-Aug & 13:00 & 30 & 179.0 & 1 & & & 1 & & 1 \\
\hline 7-Aug & $13: 30$ & 30 & 179.5 & 1 & $\theta$ & $e$ & 1 & $e$ & $1 e$ \\
\hline 7-Aug & $14: 00$ & 30 & 180.0 & 1 & & & 1 & & 1 \\
\hline 7-Aug & $14: 30$ & 30 & 180.5 & 1 & $e$ & $\theta$ & 1 & $e$ & $1 e$ \\
\hline 7-Aug & $15: 00$ & 30 & 181.0 & 1 & & & 0 & & 1 \\
\hline 7-Aug & $15: 30$ & 30 & 181.5 & 1 & $\theta$ & $e$ & 0 & $e$ & 10 \\
\hline 7-Aug & $16: 00$ & 30 & 182.0 & 1 & & & 0 & & 1 \\
\hline 7-Aug & $16: 30$ & 30 & 182.5 & 1 & $\theta$ & $\theta$ & 0 & $e$ & $1 e$ \\
\hline 7-Aug & $17: 00$ & 30 & 183.0 & 1 & & & 0 & & 1 \\
\hline 7-Aug & $17: 30$ & 30 & 183.5 & 1 & $\theta$ & $\theta$ & 0 & $e$ & $1 e$ \\
\hline 7-Aug & $18: 00$ & 30 & 184.0 & 1 & & & 0 & & 1 \\
\hline 7-Aug & $18: 30$ & 30 & 184.5 & 1 & $\theta$ & $e$ & 0 & $\theta$ & $1 e$ \\
\hline 7-Aug & $19: 00$ & 30 & 185.0 & 1 & & & 0 & & 1 \\
\hline 7-Aug & $19: 30$ & 30 & 185.5 & 1 & $\theta$ & $e$ & 0 & $e$ & $1 e$ \\
\hline 7-Aug & $20: 00$ & 30 & 186.0 & 1 & & & 0 & & 1 \\
\hline 7-Aug & $20: 30$ & 30 & 186.5 & 1 & $\theta$ & $e$ & 0 & $\theta$ & $1 e$ \\
\hline 7-Aug & $21: 00$ & 30 & 187.0 & 1 & & & 0 & & 1 \\
\hline 7-Aug & $21: 30$ & 30 & 187.5 & 1 & $\theta$ & e & 0 & $\theta$ & $1 \mathrm{e}$ \\
\hline 7-Aug & $22: 00$ & 30 & 188.0 & 1 & & & 0 & & 1 \\
\hline 7-Aug & $22: 30$ & 30 & 188.5 & 1 & $\theta$ & $\theta$ & 0 & $\theta$ & $1 \mathrm{e}$ \\
\hline
\end{tabular}


TABLE C.3 (Cont.)

\begin{tabular}{|c|c|c|c|c|c|c|c|c|c|c|}
\hline \multirow[b]{2}{*}{ Date } & \multirow[b]{2}{*}{ Time } & \multirow[b]{2}{*}{$\begin{array}{c}\text { Time Since } \\
\text { Last Sample } \\
\text { (min.) }\end{array}$} & \multirow[b]{2}{*}{$\begin{array}{l}\text { Elapsed } \\
\text { Time } \\
\text { (hours) }\end{array}$} & \multicolumn{7}{|c|}{ Turbidity (a) } \\
\hline & & & & $\begin{array}{l}\text { Background } \\
\text { (NTU) }\end{array}$ & & $\begin{array}{r}600 \mathrm{ft} \\
\text { Downstream } \\
(\mathrm{NTU})\end{array}$ & & $\begin{array}{r}\text { Net (b) } \\
\text { (NTU) }\end{array}$ & & $\begin{array}{c}\text { At } \\
\text { Crossing \#8 } \\
\text { (NTU) } \\
\end{array}$ \\
\hline 7-Aug & $23: 00$ & 30 & 189.0 & 1 & & 1 & & 0 & & 1 \\
\hline 7-Aug & $23: 30$ & 30 & 189.5 & 1 & $\theta$ & 1 & $\theta$ & 0 & $\theta$ & $1 e$ \\
\hline 8-Aug & $0: 00$ & 30 & 190.0 & 1 & & 1 & & 0 & & 1 \\
\hline 8-Aug & $0: 30$ & 30 & 190.5 & 1 & $\theta$ & 1 & $\theta$ & 0 & e & $1 e$ \\
\hline 8-Aug & $1: 00$ & 30 & 191.0 & 1 & & 1 & & 0 & & 1 \\
\hline 8-Aug & $1: 30$ & 30 & 191.5 & 1 & $\theta$ & 1 & $\theta$ & 0 & $\theta$ & $1 \theta$ \\
\hline 8-Aug & 2:00 & 30 & 192.0 & 1 & & 1 & & 0 & & 1 \\
\hline 8-Aug & $2: 30$ & 30 & 192.5 & 1 & $e$ & 1 & $\theta$ & 0 & $\theta$ & $1 e$ \\
\hline 8-Aug & 3:00 & 30 & 193.0 & 1 & & 1 & & 0 & & 1 \\
\hline 8-Aug & $3: 30$ & 30 & 193.5 & 1 & $\theta$ & 1 & $\theta$ & 0 & $\theta$ & $1 e$ \\
\hline 8-Aug & 4:00 & 30 & 194.0 & 1 & & 1 & & 0 & & 1 \\
\hline 8-Aug & $4: 30$ & 30 & 194.5 & 1 & $\theta$ & 1 & $\theta$ & 0 & $\theta$ & $1 e$ \\
\hline 8-Aug & $5: 00$ & 30 & 195.0 & 1 & & 1 & & 0 & & 1 \\
\hline 8-Aug & $5: 30$ & 30 & 195.5 & 1 & $\theta$ & 1 & $\theta$ & 0 & e & $1 e$ \\
\hline 8-Aug & $6: 00$ & 30 & 196.0 & 1 & & 1 & & 0 & & 1 \\
\hline 8-Aug & $6: 30$ & 30 & 196.5 & 1 & $\theta$ & 1 & $\theta$ & 0 & $\theta$ & $1 e$ \\
\hline 8-Aug & $7: 00$ & 30 & 197.0 & 1 & & 1 & & 0 & & 1 \\
\hline 8-Aug & $7: 30$ & 30 & 197.5 & 1 & $\theta$ & 1 & $\theta$ & 0 & $\theta$ & $1 e$ \\
\hline 8-Aug & $8: 00$ & 30 & 198.0 & 1 & & 1 & & 0 & & 1 \\
\hline 8-Aug & $8: 30$ & 30 & 198.5 & 1 & $\theta$ & 1 & $\theta$ & 0 & $\theta$ & $1 e$ \\
\hline 8-Aug & 9:00 & 30 & 199.0 & 1 & & 1 & & 0 & & 1 \\
\hline 8-Aug & $9: 30$ & 30 & 199.5 & 1 & $\theta$ & 1 & $\theta$ & 0 & $\theta$ & $1 e$ \\
\hline 8-Aug & $10: 00$ & 30 & 200.0 & 1 & & 1 & & 0 & & 1 \\
\hline 8-Aug & $10: 30$ & 30 & 200.5 & 1 & $\theta$ & 1 & $\theta$ & 0 & $\theta$ & $1 e$ \\
\hline 8-Aug & $11: 00$ & 30 & 201.0 & 1 & & 1 & & 0 & & 1 \\
\hline 8-Aug & $11: 30$ & 30 & 201.5 & 1 & $\theta$ & 1 & $\theta$ & 0 & $\theta$ & $1 e$ \\
\hline 8-Aug & $12: 00$ & 30 & 202.0 & 1 & & 1 & & 0 & & 1 \\
\hline 8-Aug & $12: 30$ & 30 & 202.5 & 1 & $\theta$ & 1 & $\theta$ & 0 & $\theta$ & $1 e$ \\
\hline 8-Aug & $13: 00$ & 30 & 203.0 & 1 & & 1 & & 0 & & 1 \\
\hline 8-Aug & $13: 30$ & 30 & 203.5 & 1 & $e$ & 1 & $\theta$ & 0 & $\theta$ & $1 e$ \\
\hline 8-Aug & $14: 00$ & 30 & 204.0 & 1 & & 1 & & 0 & & 1 \\
\hline 8-Aug & $14: 30$ & 30 & 204.5 & 1 & $\theta$ & 1 & $\theta$ & 0 & $\theta$ & $1 \mathrm{e}$ \\
\hline 8-Aug & $15: 00$ & 30 & 205.0 & 1 & & 1 & & 0 & & 1 \\
\hline 8-Aug & $15: 30$ & 30 & 205.5 & 1 & $\theta$ & 1 & $\theta$ & 0 & e & $1 e$ \\
\hline 8-Aug & $16: 00$ & 30 & 206.0 & 1 & & 1 & & 0 & & 1 \\
\hline 8-Aug & $16: 30$ & 30 & 206.5 & 1 & $\theta$ & 1 & $\theta$ & 0 & $\theta$ & $1 \mathrm{e}$ \\
\hline 8-Aug & $17: 00$ & 30 & 207.0 & 1 & & 1 & & 0 & & 1 \\
\hline 8-Aug & $17: 30$ & 30 & 207.5 & 1 & $\theta$ & 1 & $\theta$ & 0 & $\theta$ & $1 e$ \\
\hline 8-Aug & $18: 00$ & 30 & 208.0 & 1 & & 1 & & 0 & & 1 \\
\hline 8-Aug & $18: 30$ & 30 & 208.5 & 1 & $e$ & 1 & $e$ & 0 & $\theta$ & $1 e$ \\
\hline 8-Aug & $19: 00$ & 30 & 209.0 & 1 & & 1 & & 0 & & 1 \\
\hline 8-Aug & $19: 30$ & 30 & 209.5 & 1 & $\theta$ & 1 & $\theta$ & 0 & $\theta$ & $1 e$ \\
\hline
\end{tabular}


TABLE C.3 (Cont.)

\begin{tabular}{|c|c|c|c|c|c|c|c|c|c|}
\hline \multirow[b]{2}{*}{ Date } & \multirow[b]{2}{*}{ Time } & \multirow[b]{2}{*}{$\begin{array}{c}\text { Time Since } \\
\text { Last Sample } \\
\text { (min.) }\end{array}$} & \multirow[b]{2}{*}{$\begin{array}{l}\text { Elapsed } \\
\text { Time } \\
\text { (hours) }\end{array}$} & \multicolumn{6}{|c|}{ Turbidity (a) } \\
\hline & & & & $\begin{array}{r}\text { Background } \\
\text { (NTU) }\end{array}$ & & & $\begin{array}{r}\text { Net (b) } \\
\text { (NTU) } \\
\end{array}$ & & $\begin{array}{c}\text { At } \\
\text { Crossing \#8 } \\
\text { (NTU) } \\
\end{array}$ \\
\hline 8-Aug & $20: 00$ & 30 & 210.0 & 1 & & & 0 & & 1 \\
\hline 8-Aug & $20: 30$ & 30 & 210.5 & 1 & $\theta$ & $\theta$ & 0 & $\theta$ & $1 e$ \\
\hline 8-Aug & 21:00 & 30 & 211.0 & 1 & & & 0 & & 1 \\
\hline 8-Aug & $21: 30$ & 30 & 211.5 & & $\theta$ & $\theta$ & 0 & $\theta$ & $1 \theta$ \\
\hline 8-Aug & 22:00 & 30 & 212.0 & 1 & & & 0 & & 1 \\
\hline 8-Aug & 22:30 & 30 & 212.5 & 1 & $\theta$ & $\theta$ & 0 & $\theta$ & $1 e$ \\
\hline 8-Aug & 23:00 & 30 & 213.0 & 1 & & & 0 & & 1 \\
\hline 8-Aug & $23: 30$ & 30 & 213.5 & 1 & $\theta$ & $\theta$ & 0 & e & $1 e$ \\
\hline 9-Aug & $0: 00$ & 30 & 214.0 & 1 & & & 0 & & 1 \\
\hline 9-Aug & $0: 30$ & 30 & 214.5 & 1 & $\theta$ & $\theta$ & 0 & $\theta$ & $1 \theta$ \\
\hline 9-Aug & $1: 00$ & 30 & 215.0 & 1 & & & 0 & & 1 \\
\hline 9-Aug & $1: 30$ & 30 & 215.5 & 1 & $\theta$ & e & 0 & $\theta$ & $1 \theta$ \\
\hline 9-Aug & $2: 00$ & 30 & 216.0 & 1 & & & 0 & & 1 \\
\hline 9-Aug & $2: 30$ & 30 & 216.5 & 1 & $\theta$ & $\theta$ & 0 & e & $1 e$ \\
\hline 9-Aug & $3: 00$ & 30 & 217.0 & 1 & & & 0 & & 1 \\
\hline 9-Aug & $3: 30$ & 30 & 217.5 & 1 & $e$ & $\theta$ & 0 & $\theta$ & $1 e$ \\
\hline 9-Aug & $4: 00$ & 30 & 218.0 & 1 & & & 0 & & 1 \\
\hline 9-Aug & $4: 30$ & 30 & 218.5 & 1 & $\theta$ & $\theta$ & 0 & e & $1 e$ \\
\hline 9-Aug & $5: 00$ & 30 & 219.0 & 1 & & & 0 & & 1 \\
\hline 9-Aug & $5: 30$ & 30 & 219.5 & 1 & $\theta$ & $\theta$ & 0 & $\theta$ & $1 e$ \\
\hline 9-Aug & $6: 00$ & 30 & 220.0 & 1 & & & 0 & & 1 \\
\hline 9-Aug & $6: 30$ & 30 & 220.5 & 1 & $\theta$ & $\theta$ & 0 & e & $1 e$ \\
\hline 9-Aug & $7: 00$ & 30 & 221.0 & 1 & & & 0 & & 1 \\
\hline 9-Aug & 7:30 & 30 & 221.5 & 1 & $\theta$ & $\theta$ & 0 & e & $1 e$ \\
\hline 9-Aug & $8: 00$ & 30 & 222.0 & 1 & & & 0 & & 1 \\
\hline
\end{tabular}

(a) $\mathrm{m}=$ sample $\mathrm{missed} / \mathrm{value}$ is extrapolated;

$\theta=$ measurements from previous samples are extrapolated for graphing purposes only

(b) Note: If the upstream turbidity reading was higher than the simultaneous downstream reading, net turbidity was equal to 0 . Also, after upstream sampler was removed, all subsequent net turbidity values were assumed to be zero.

Total Net Downstream Flow-Weighted NTU*hours $=1969$ 
TABLE C.4 Turbidity Generated by Crossing \#4

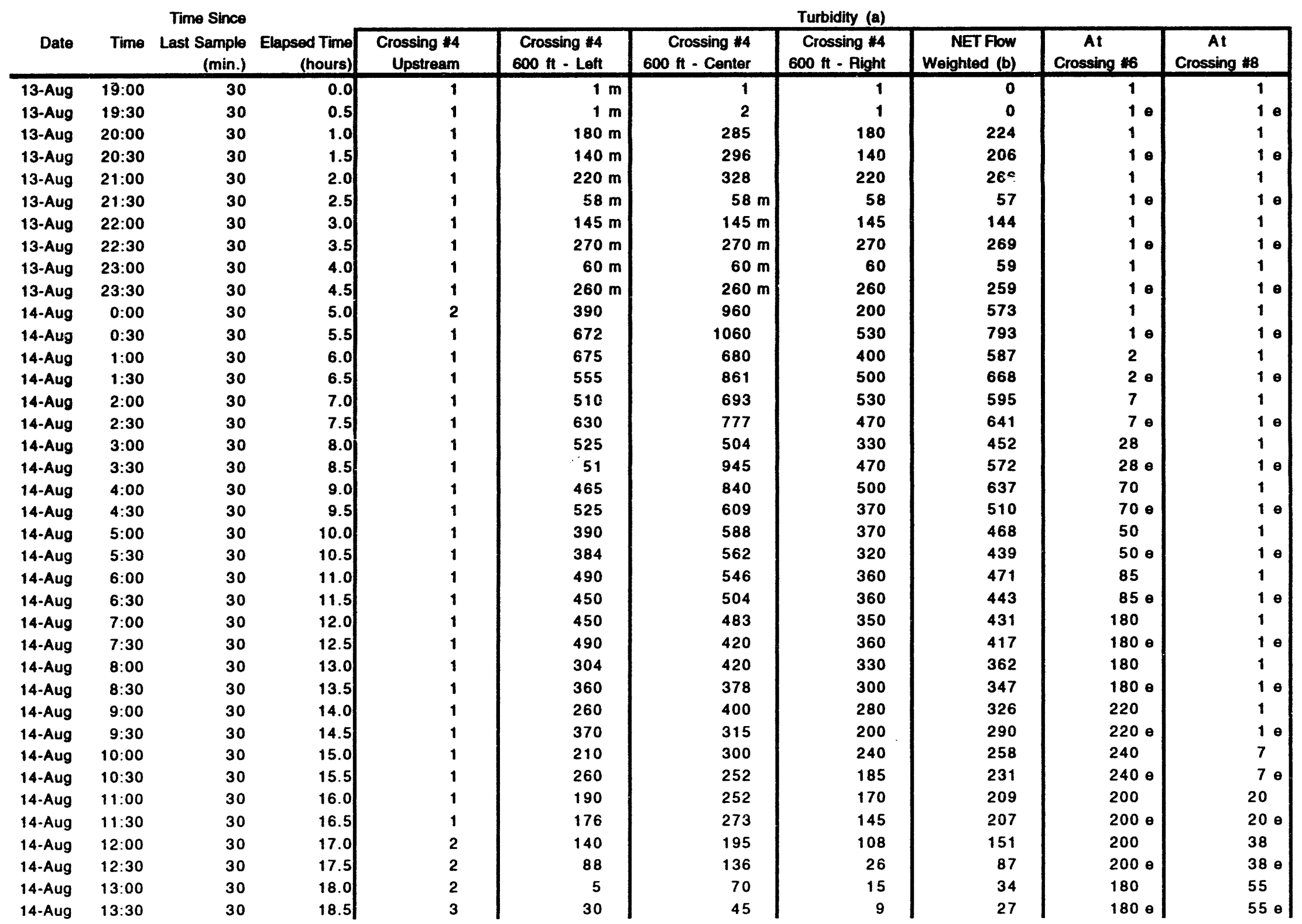


TABLE C.4 (Cont.)

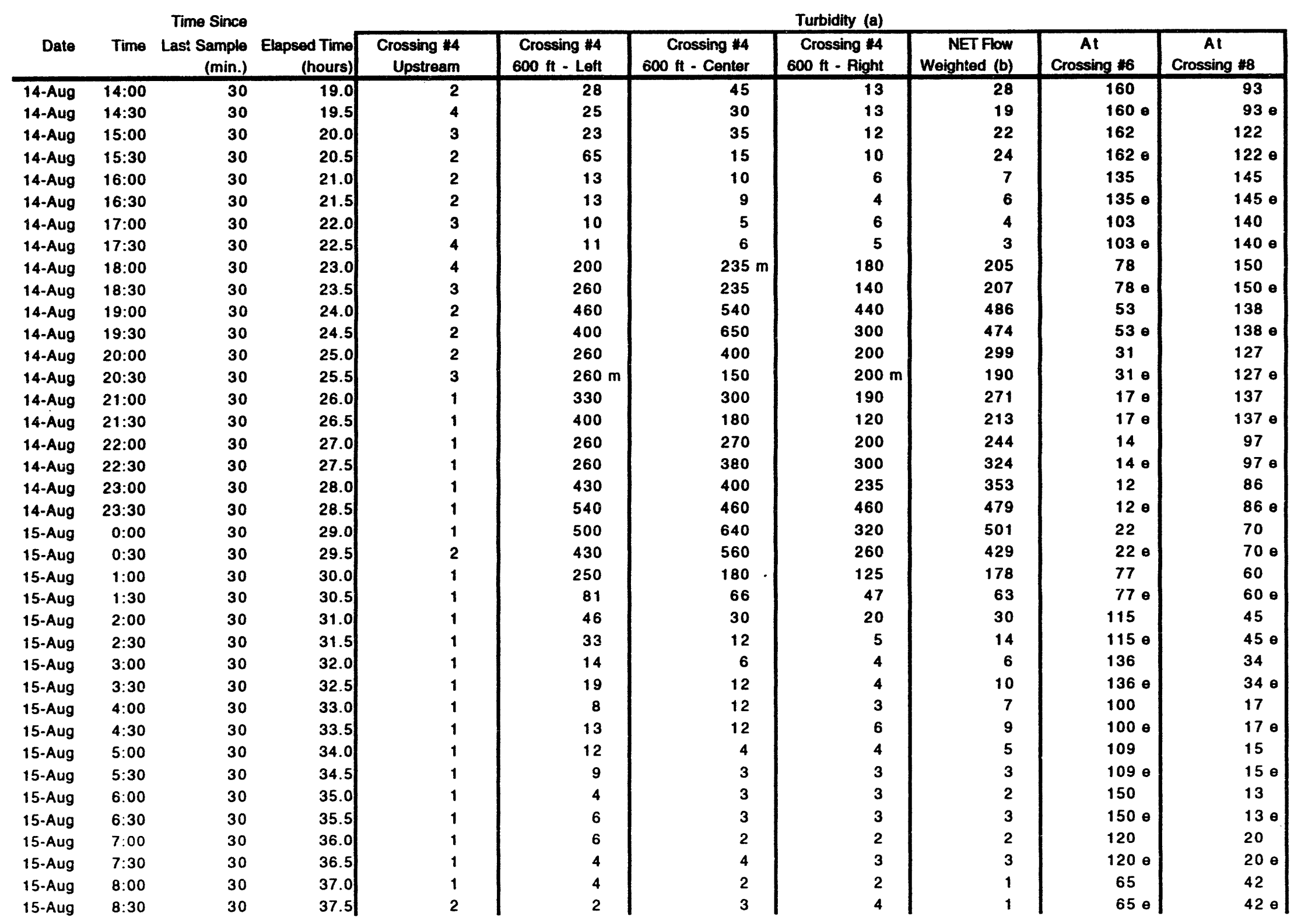


TABLE C.4 (Cont.)

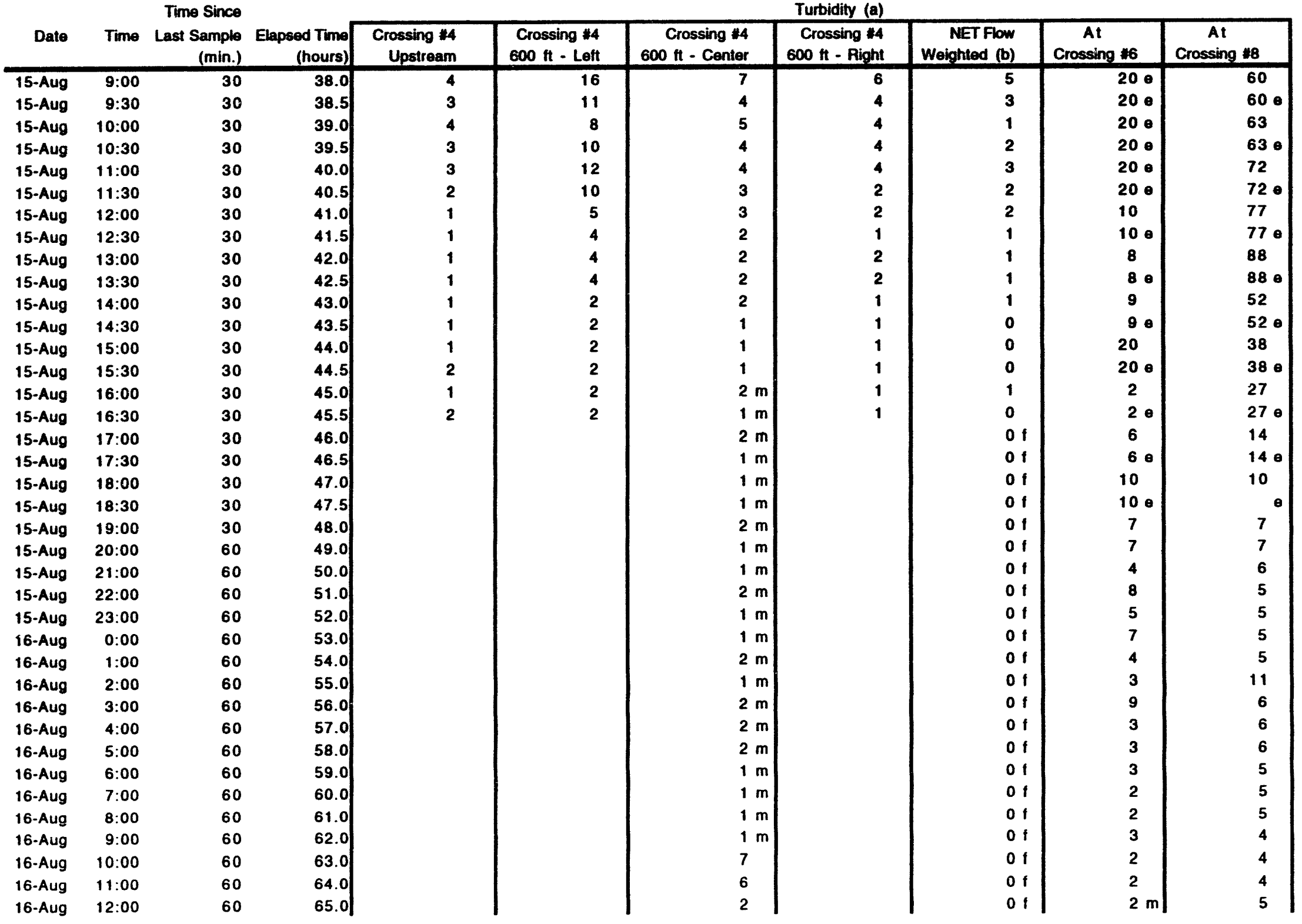


TABLE C.4 (Cont.)

Time Since

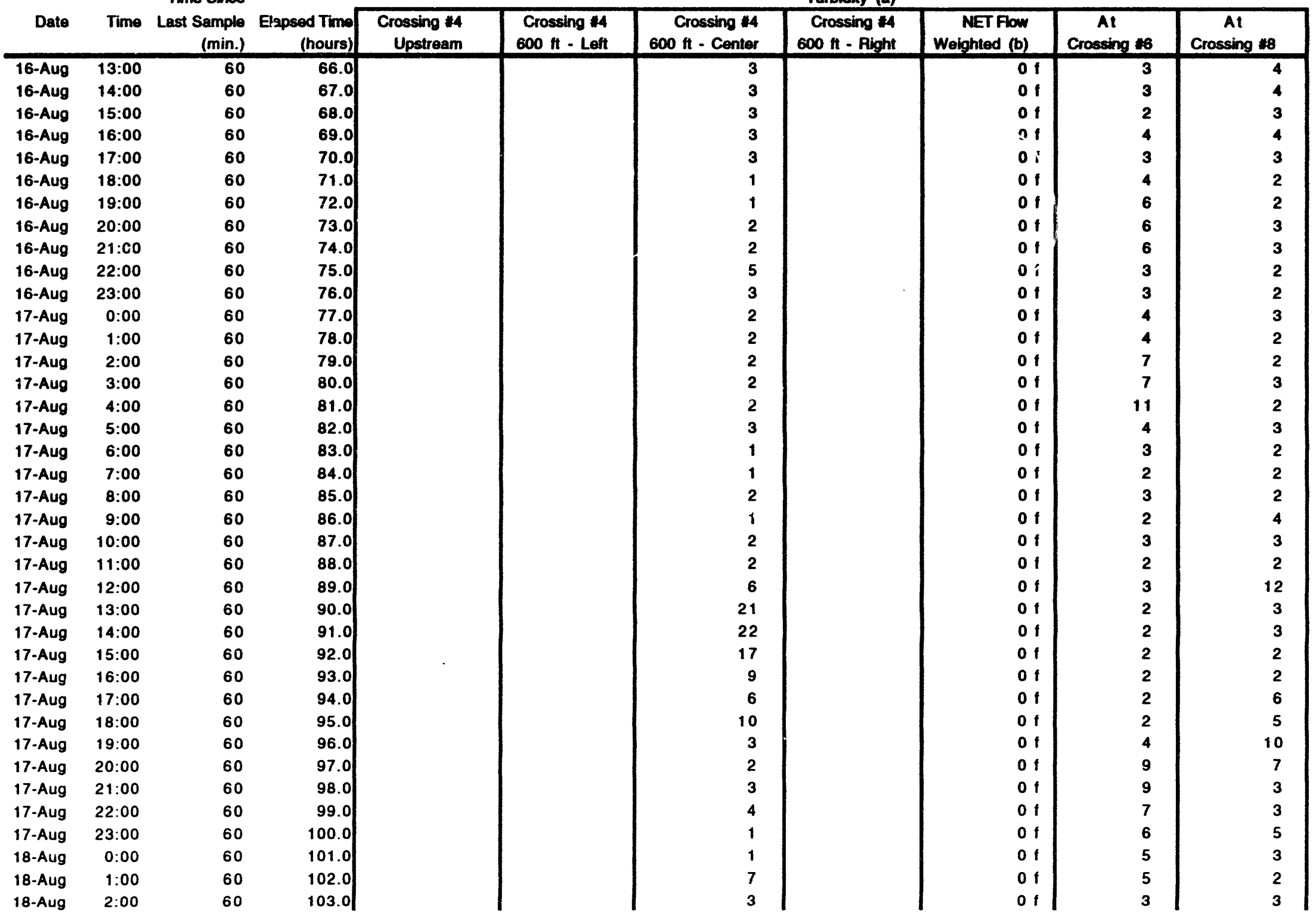


TABLE C.4 (Cont.)

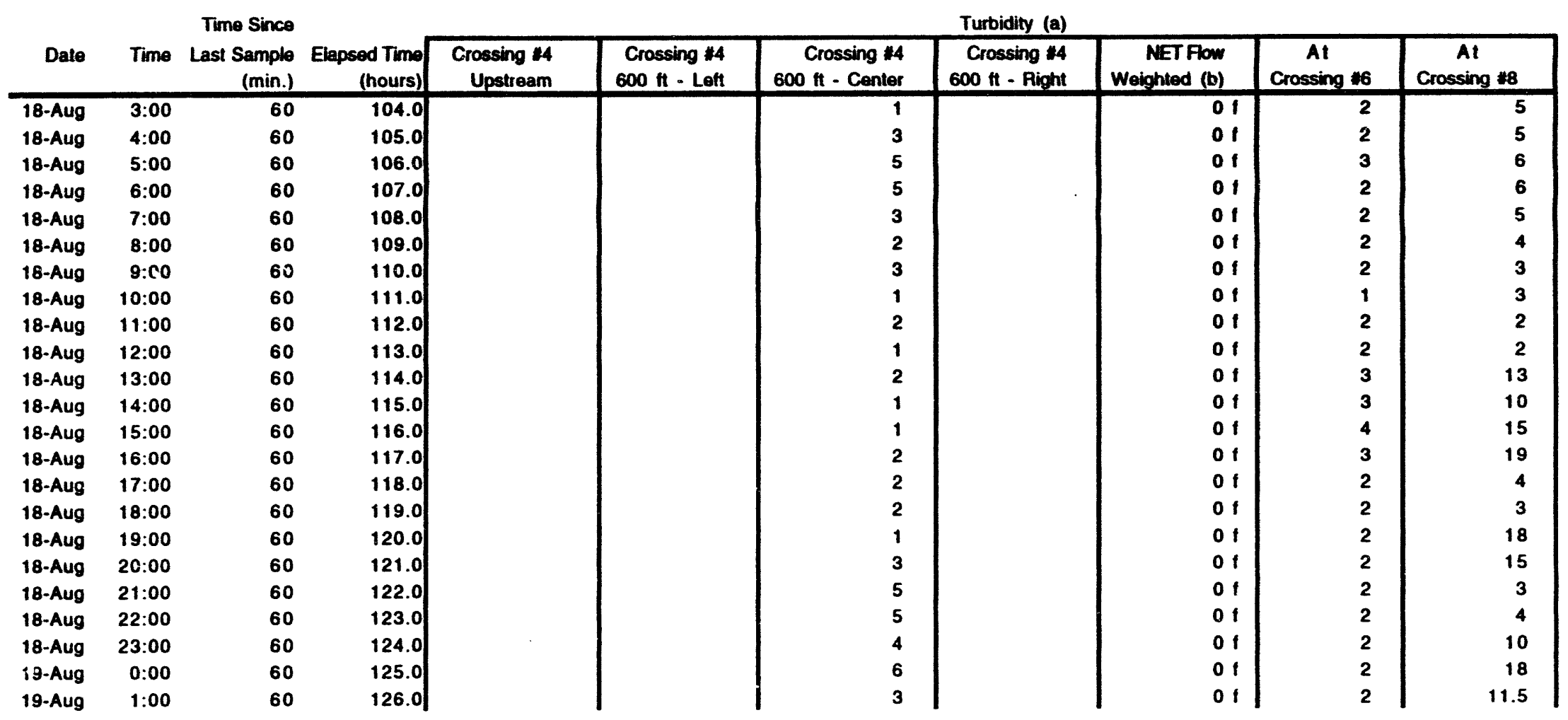

(a) $\mathbf{m}=$ sample missed/value is interpolated;

e = measurements from previous samples are extrapolated for graphing purposes only

$f=$ after the upstream sampler is removed, the NET flow weighted turbidity is assumed to be zero (for the purposes of calculating the 10 day running average of NET flow weighted turbidity only)

(b) Note: If the upstream turbidity reading was higher than the simultaneous downstream reading, net tubidity was equal to 0 . Also, after upstream sampler was removed, all subsequent net turbidity values were assumed to be zero.

Total Net Downstream Flow Weighted NTU*hrs =

8931 

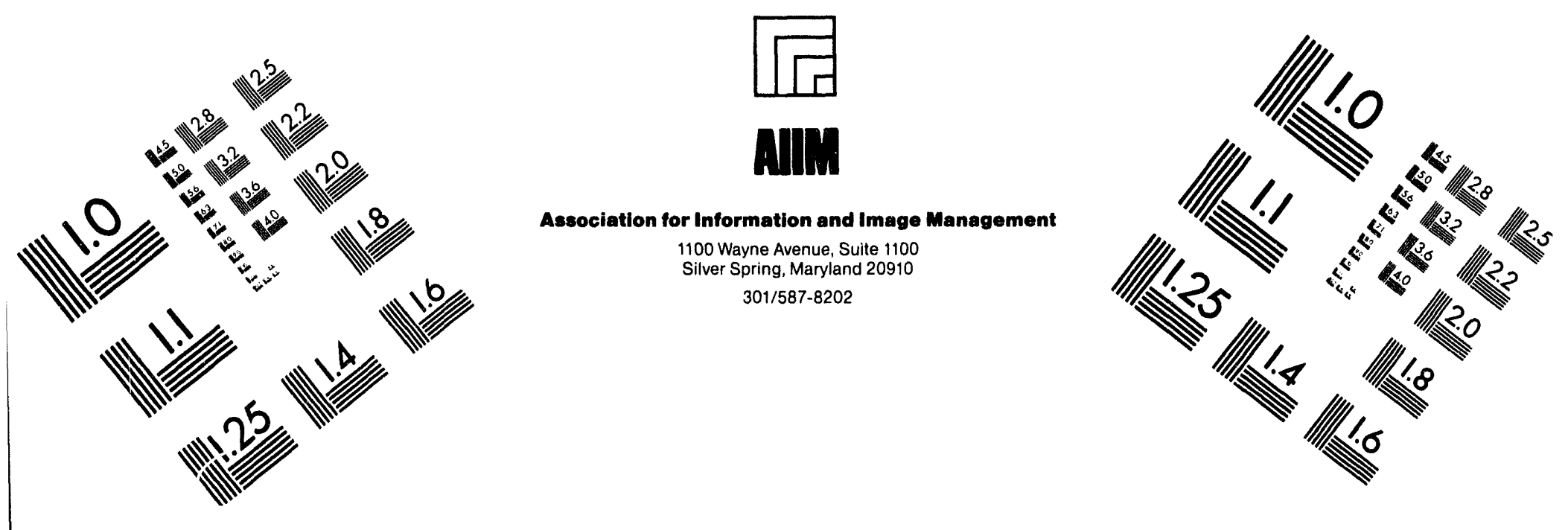

\section{Centimeter}

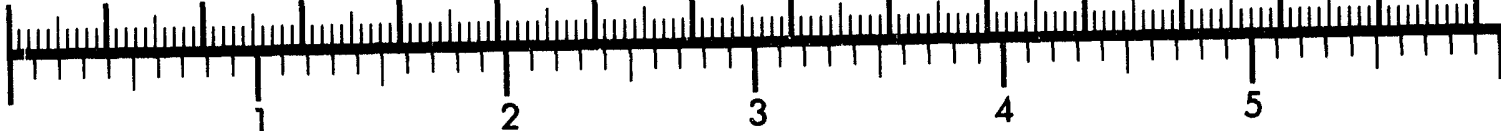
Inches
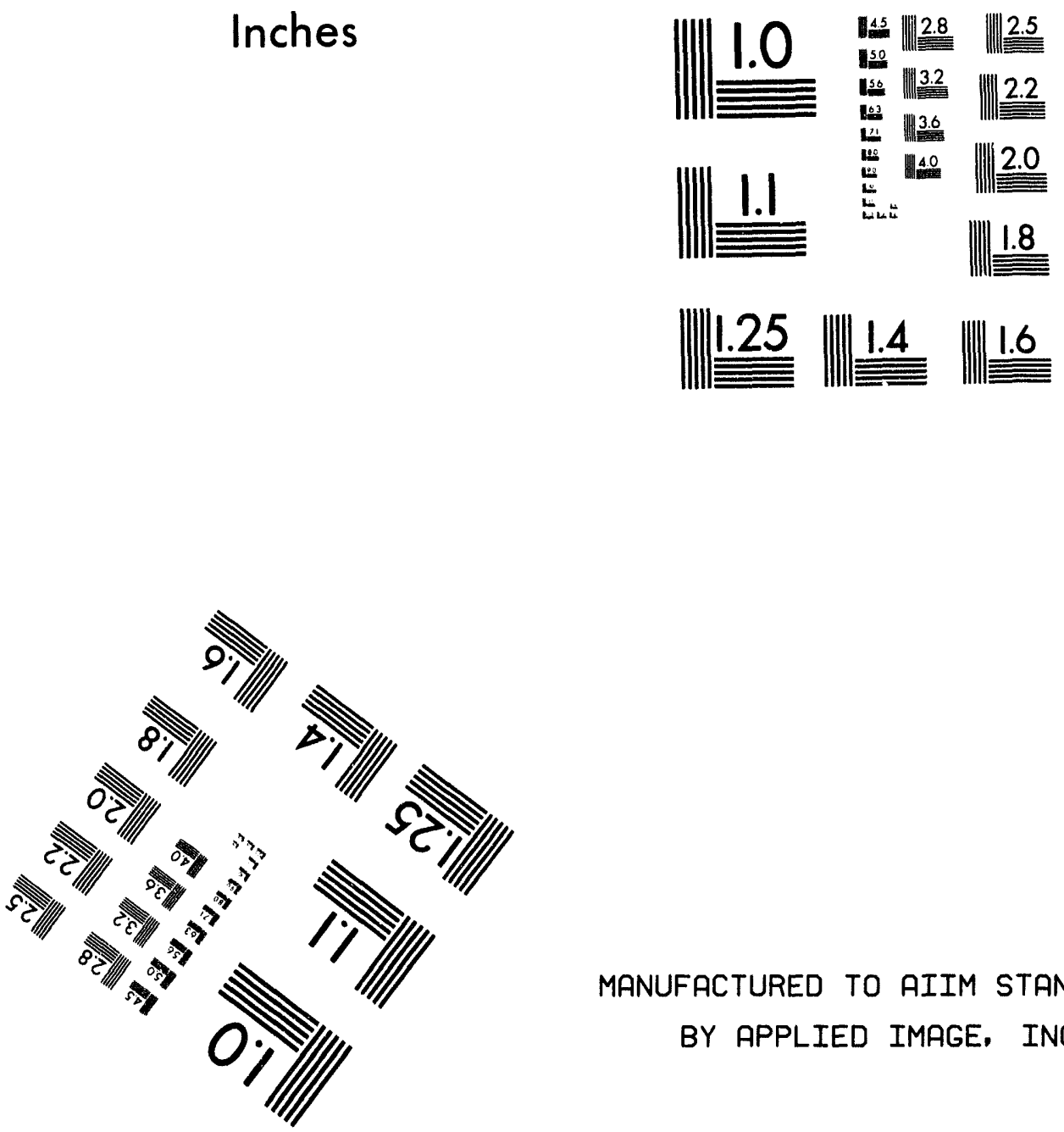

MANUFACTURED TO AIIM STANDARDS

BY APPLIED IMAGE, INC.

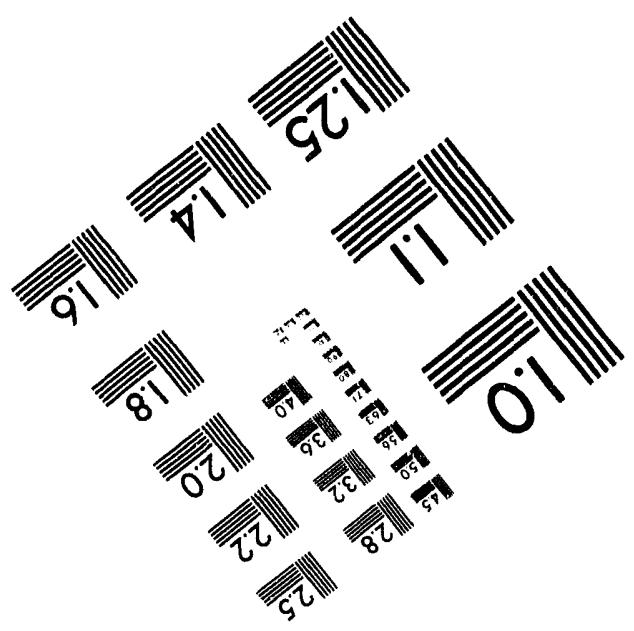



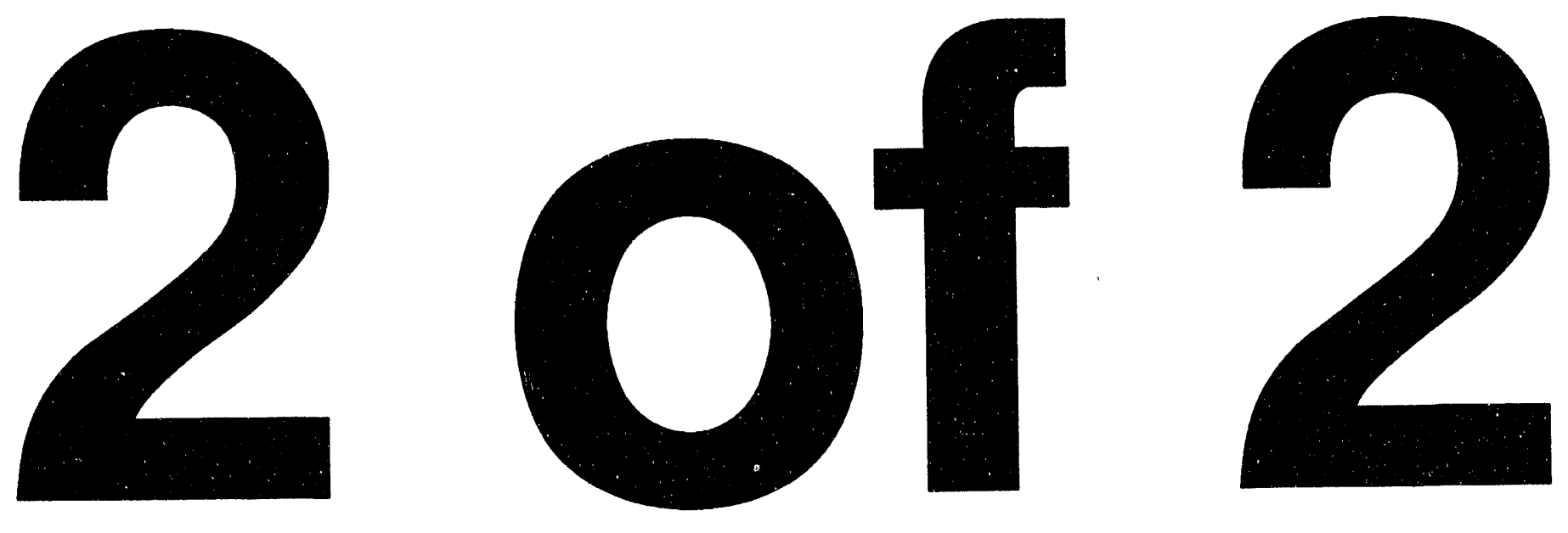
TABLE C.5 (Cont.)

Time Since

Turbidity (a)

\begin{tabular}{|c|c|c|c|c|c|c|c|c|c|c|c|}
\hline \multirow{2}{*}{ Date } & & \\
\hline & Time & $\begin{array}{r}\text { Last Sample } \\
\text { (min.) }\end{array}$ & $\begin{array}{r}\text { Elapsed Time } \\
\text { (hours) }\end{array}$ & $\begin{array}{r}\text { Crossing \#5 } \\
\text { Upstream }\end{array}$ & $\begin{array}{l}\text { Crossing \#5 } \\
600 \mathrm{ft} \text { - Left }\end{array}$ & $\begin{array}{r}\text { Crossing \#5 } \\
600 \mathrm{ft} \text { - Center }\end{array}$ & $\begin{array}{r}\text { Crossing \#5 } \\
600 \mathrm{ft} \text { - Right }\end{array}$ & $\begin{array}{r}\text { NET Flow } \\
\text { Woighted (b) }\end{array}$ & $\begin{array}{c}\text { At } \\
\text { Crossing } * 4\end{array}$ & $\begin{array}{c}\text { At } \\
\text { Crossing \#6 }\end{array}$ & $\begin{array}{c}\text { At } \\
\text { Crossing } \# 8\end{array}$ \\
\hline 19-Aug & $21: 00$ & 30 & 18.0 & 1 & 167 & 310 & 299 & 272 & $2 \theta$ & 79 & 74 \\
\hline 19-Aug & $21: 30$ & 30 & 19.5 & 5 & 145 & 398 & 342 & 308 & 2 e & 79 ө & $74 \theta$ \\
\hline 19-Aug & $22: 00$ & 30 & 20.0 & 4 & 285 & 254 & 238 & 248 & 2 & 52 & 73 \\
\hline 19-Aug & $22: 30$ & 30 & 20.5 & 2 & 231 & 266 & 231 & 238 & 20 & $52 \theta$ & 730 \\
\hline 19-Aug & 23:00 & 30 & 21.0 & 3 & 186 & 209 & 182 & 187 & 2 & 306 & 69 \\
\hline 19-Aug & 23:30 & 30 & 21.5 & 3 & 119 & 58 & 68 & 74 & 2 e & 306 e & $69 \theta$ \\
\hline 20-Aug & $0: 00$ & 30 & 22.0 & 3 & 72 & 21 & 16 & 27 & 2 & 63 & 72 \\
\hline 20-Aug & $0: 30$ & 30 & 22.5 & 3 & 46 & 17 & 16 & 20 & 2 e & $63 \mathrm{e}$ & $72 \theta$ \\
\hline 20-Aug & $1: 00$ & 30 & 23.0 & 2 & 56 & 11 & 12 & 19 & 2 & 97 & 84 \\
\hline 20-Aug & $1: 30$ & 30 & 23.5 & 1 & 34 & 8 & 5 & 11 & 20 & 97 e & $84 \mathrm{e}$ \\
\hline 20-Aug & 2:00 & 30 & 24.0 & 3 & 26 & 7 & 4 & 7 & 1 & 100 & 78 \\
\hline 20-Aug & $2: 30$ & 30 & 24.5 & 3 & 25 & 8 & 2 & 6 & 10 & $100 \theta$ & $78 \theta$ \\
\hline 20-Aug & 3:00 & 30 & 25.0 & 2 & 23 & 7 & 6 & 8 & 1 & 68 & 73 \\
\hline 20-Aug & $3: 30$ & 30 & 25.5 & 3 & 39 & 6 & 3 & 9 & 10 & 68 o & 730 \\
\hline 20-Aug & 4:00 & 30 & 26.0 & 3 & 18 & 16 & 3 & 7 & 1 & 31 & 68 \\
\hline 20-Aug & $4: 30$ & 30 & 26.5 & 3 & 15 & 5 & 3 & 3 & 10 & $31 \theta$ & $68 \mathrm{e}$ \\
\hline 20-Aug & 5:00 & 30 & 27.0 & 2 & 23 & 5 & 4 & 6 & 1 & 18 & 53 \\
\hline 20-Aug & $5: 30$ & 30 & 27.5 & 2 & 23 & 4 & 3 & 6 & 10 & $18 \theta$ & $53 \theta$ \\
\hline 20-Aug & 6:00 & 30 & 28.0 & 2 & 17 & 4 & 5 & 5 & 3 & 10 & 36 \\
\hline 20-Aug & $6: 30$ & 30 & 28.5 & 2 & 23 & 4 & 3 & 6 & 30 & $10 \theta$ & $36 \mathrm{e}$ \\
\hline 20-Aug & $7: 00$ & 30 & 29.0 & 1 & 4 & 2 & 2 & 1 & 2 & 7 & 35 \\
\hline 20-Aug & $7: 30$ & 30 & 29.5 & 1 & 2 & 2 & 2 & 1 & 20 & $7 \circ$ & $35 \mathrm{e}$ \\
\hline 20-Aug & $8: 00$ & 30 & 30.0 & 2 & 3 & 3 & 2 & 0 & 2 & 9 & 48 \\
\hline 20-Aug & $8: 30$ & 30 & 30.5 & 1 & 4 & 2 & 2 & 1 & $2 \theta$ & $9 \theta$ & $48 \mathrm{e}$ \\
\hline 20-Aug & $9: 00$ & 30 & 31.0 & 1 & 6 & 2 & 3 & 2 & 2 & 8 & 67 \\
\hline 20-Aug & $9: 30$ & 30 & 31.5 & 2 & 3 & 2 & 4 & 1 & 20 & 80 & $67 \mathrm{e}$ \\
\hline 20-Aug & $10: 00$ & 30 & 32.0 & 1 & 4 & 3 & 2 & 2 & 10 & 6 & 54 \\
\hline 20-Aug & $10: 30$ & 30 & 32.5 & 3 & 3 & 2 & 3 & 0 & 10 & $6 \theta$ & $54 \mathrm{\theta}$ \\
\hline 20-Aug & $11: 00$ & 30 & 33.0 & 1 & 4 & 2 & 2 & 1 & 10 & 5 & 69 \\
\hline 20-Aug & $11: 30$ & 30 & 33.5 & 2 & 4 & 2 & 5 & 2 & 10 & $5 \theta$ & $69 \mathrm{e}$ \\
\hline 20-Aug & $12: 00$ & 30 & 34.0 & 2 & 13 & 2 & 3 & 3 & 1 & 4 & 78 \\
\hline 20-Aug & $12: 30$ & 30 & 34.5 & 1 & 5 & 2 & 2 & 2 & 10 & 40 & $78 \mathrm{e}$ \\
\hline 20-Aug & $13: 00$ & 30 & 35.0 & 3 & 5 & 2 & 2 & 0 & 2 & 6 & 62 \\
\hline 20-Aug & $13: 30$ & 30 & 35.5 & 1 & 5 & 2 & 4 & 3 & 2 e & $6 e$ & $62 \theta$ \\
\hline 20-Aug & $14: 00$ & 30 & 36.0 & 1 & 2 & 1 & 8 & 4 & 1 & 8 & 31 \\
\hline 20-Aug & $14: 30$ & 30 & 36.5 & $2 \mathrm{~m}$ & 4 & 1 & 5 & 2 & 10 & 80 & $31 \mathrm{e}$ \\
\hline 20.Aug & $15: 00$ & 30 & 37.0 & $2 \mathrm{~m}$ & 3 & 3 & 1 & 0 & 1 & 5 & 21 \\
\hline 20-Aug & $15: 30$ & 30 & 37.5 & $2 \mathrm{ml}$ & 2 & 2 & 2 & 0 & 1 el & $5 \theta$ & $21 \theta$ \\
\hline
\end{tabular}


TABLE C.5 (Cont.)

Time Since

\begin{tabular}{|c|c|c|c|c|c|c|c|c|c|c|c|}
\hline \multirow[b]{2}{*}{ Date } & \multicolumn{3}{|c|}{ Time Since } & \\
\hline & Time & $\begin{array}{r}\text { Last Sample } \\
\text { (min.) }\end{array}$ & $\begin{array}{r}\begin{array}{r}\text { Elapsed Time } \\
\text { (hours) }\end{array} \\
\end{array}$ & $\begin{array}{r}\text { Crossing \#5 } \\
\text { Upstream }\end{array}$ & $\begin{array}{l}\text { Crossing \#5 } \\
600 \mathrm{ft} \text { - Left } \\
\end{array}$ & $\begin{array}{r}\text { Crossing \#5 } \\
600 \mathrm{ft} \text { - Center } \\
\end{array}$ & $\begin{array}{r}\text { Crossing \#5 } \\
600 \mathrm{ft} \text { - Right } \\
\end{array}$ & $\begin{array}{r}\text { NET Flow } \\
\text { Weighted (b) } \\
\end{array}$ & $\begin{array}{c}\text { At } \\
\text { Crossing \#4 } \\
\end{array}$ & $\begin{array}{c}\text { At } \\
\text { Crossing \#6 }\end{array}$ & $\begin{array}{c}\text { At } \\
\text { Crossing \#8 } \\
\end{array}$ \\
\hline 20-Aug & $16: 00$ & 30 & 38.0 & $2 \mathrm{~m}$ & 3 & 2 & 3 & 1 & 1 & 6 & 12 \\
\hline 20-Aug & $16: 30$ & 30 & 38.5 & & & 1 & & 01 & 10 & $6 \theta$ & $12 \theta$ \\
\hline 20-Aug & $17: 00$ & 30 & 39.0 & & & 1 & & of & 1 & 4 & 10 \\
\hline 20-Aug & $17: 30$ & 30 & 39.5 & & & $1 e$ & & of & 10 & 4 이 & $10 \theta$ \\
\hline 20-Aug & $18: 00$ & 30 & 40.0 & & & 2 & & of & 1 & 3 & 23 \\
\hline 20-Aug & $18: 30$ & 30 & 40.5 & & & 20 & & $0 f$ & 10 & 30 & $23 \theta$ \\
\hline 20-Aug & $19: 00$ & 30 & 41.0 & & & 3 & & $0 \mathrm{f}$ & 1 & 3 & 17 \\
\hline 20-Aug & $19: 30$ & 30 & 41.5 & & & 3 e & & $0 t$ & 10 & $3 e$ & 17 e \\
\hline 20-Aug & $20: 00$ & 30 & 42.0 & & & 4 & & $0 \mathrm{f}$ & 1 & 2 & 10 \\
\hline 20-Aug & $20: 30$ & 30 & 42.5 & & & 40 & & $0 \mathrm{f}$ & 10 & $2 \theta$ & $10 \theta$ \\
\hline 20-Aug & $21: 00$ & 30 & 43.0 & & & 3 & & $0 f$ & 1 & 4 & 10 \\
\hline 20-Aug & $21: 30$ & 30 & 43.5 & & & $3 \theta$ & & $0 \mathrm{f}$ & 10 & 40 & $10 \theta$ \\
\hline 20-Aug & $22: 00$ & 30 & 44.0 & & & 2 & & $0 \mathrm{f}$ & 1 & 3 & 10 \\
\hline 20-Aug & $22: 30$ & 30 & 44.5 & & & $2 \theta$ & & of & 10 & 30 & $10 \theta$ \\
\hline 20-Aug & 23:00 & 30 & 45.0 & & & 4 & & $0 f$ & 1 & 4 & 8 \\
\hline 20-Aug & $23: 30$ & 30 & 45.5 & & & $4 e$ & & $0 \mathrm{f}$ & $1 \theta$ & $4 \theta$ & 8 e \\
\hline 21-Aug & $0: 00$ & 30 & 46.0 & & & 2 & & $0 f$ & 1 & 5 & 8 \\
\hline 21-Aug & $0: 30$ & 30 & 46.5 & & & $2 \theta$ & & $0 \mathrm{f}$ & 10 & $5 \theta$ & 80 \\
\hline & $1: 00$ & 30 & 47.0 & & & 5 & & $0 \mathrm{f}$ & 1 & 5 & 5 \\
\hline
\end{tabular}

(a) $\mathrm{m}$ = sample $\mathrm{missed} / \mathrm{valu \theta}$ is extrapolated;

$\theta=$ measurement from previous samples are extrooolated fn! yraphing purposes only

$f=$ after the upstream sampler is removed, the NET flow weighted turbidity is assumed to be zero

(for the purposes of calculating the 10 day running average of NET flow weighted turbidity only)

(b) Note: If the upstream turbidity reading was higher than the simultaneous downstream reading, net turbidity

was equal to 0 . Also, after the upstream sampler was removed, all subsequent net turbidity values were assumed to be zero.

Total Net Downstream Flow-Weighted NTUthours = 3663 
TABLE C.6 Turbidity Generated by Crossing \#7

\begin{tabular}{|c|c|c|c|c|c|c|c|c|c|c|c|c|}
\hline & & Time Since & & & & & & Turbidity (a) & & & & \\
\hline Date & Time & $\begin{array}{r}\text { Last Sample } \\
\text { (min.) }\end{array}$ & $\begin{array}{r}\text { Elapsed Time } \\
\text { (hours) }\end{array}$ & $\begin{array}{r}\text { Crossing } \$ 7 \\
\text { Upstream }\end{array}$ & $\begin{array}{r}\text { Crossing \#7 } \\
600 \mathrm{ft} \text { - Left } \\
\end{array}$ & $\begin{array}{r}\text { Crossing } \# 7 \\
600 \mathrm{H} \text { - Center }\end{array}$ & $\begin{array}{r}\text { Crossing \#7 } \\
600 \mathrm{ft} \text { - Right }\end{array}$ & $\begin{array}{c}\text { NET Flow } \\
\text { Weighted (b) }\end{array}$ & $\begin{array}{c}\text { At } \\
\text { Crossing } \# 4\end{array}$ & $\begin{array}{c}\text { At } \\
\text { Crossing } \# 5\end{array}$ & $\begin{array}{c}\text { At } \\
\text { Crossing } \# 6\end{array}$ & $\begin{array}{c}\text { At } \\
\text { Crossing } 18\end{array}$ \\
\hline 21-Aug & $2: 00$ & 30 & 0.0 & 45 & 4 & 3 & 2 & 0 & 1 & 4 & 4 & 7 \\
\hline 21-Aug & $2: 30$ & 30 & 0.5 & 4 & 4 & 2 & 3 & 0 & $1 e$ & $4 \theta$ & 40 & 70 \\
\hline 21-Aug & $3: 00$ & 30 & 1.0 & 3 & 3 & 2 & 4 & 0 & 1 & 2 & 3 & 5 \\
\hline 21-Aug & $3: 30$ & 30 & 1.5 & 3 & 18 & 5 & 5 & 8 & $2 \theta$ & $2 \theta$ & 3 e & $5 \theta$ \\
\hline 21-Aug & $4: 00$ & 30 & 2.0 & $3 \mathrm{~s}$ & 9 & 3 & 3 & 3 & 2 & 3 & 3 & 5 \\
\hline 21-Aug & $4: 30$ & 30 & 2.5 & $3 s$ & 9 & 6 & 4 & 4 & 60 & 30 & 3 e & 50 \\
\hline 21-Aug & $5: 00$ & 30 & 3.0 & $3 s$ & 7 & 5 & 3 & 3 & 6 & 2 & 3 & 4 \\
\hline 21-Aug & $5: 30$ & 30 & 3.5 & 38 & 6 & 3 & 7 & 2 & 10 & $2 \theta$ & 30 & $4 \theta$ \\
\hline 21-Aug & $6: 00$ & 30 & 4.0 & 38 & 440 & 26 & 7 & 217 & 1 & 2 & 3 & 6 \\
\hline 21-Aug & $6: 30$ & 30 & 4.5 & $3 \mathrm{~s}$ & 847 & 68 & 4 & 427 & 10 & 20 & 30 & 60 \\
\hline 21-Aug & $7: 00$ & 30 & 5.0 & 38 & 683 & 138 & 9 & 380 & 1 & 1 & 3 & 4 \\
\hline 21-Aug & $7: 30$ & 30 & 5.5 & $3 \mathrm{~s}$ & 858 & 209 & 17 & 493 & 10 & 10 & $3 \mathrm{e}$ & 40 \\
\hline 21-Aug & $8: 00$ & 30 & 6.0 & 38 & 819 & 182 & 12 & 463 & 1 & 3 & 3 & 3 \\
\hline 21-Aug & $8: 30$ & 30 & 6.5 & $3 \mathrm{~s}$ & 609 & 160 & 9 & 354 & 10 & 3 e & 3 o & 30 \\
\hline 21-Aug & 9:00 & 30 & 7.0 & $2 s$ & 165 & 94 & 37 & 120 & 1 & 1 & 2 & 5 \\
\hline 21-Aug & $9: 30$ & 30 & 7.5 & 28 & 80 & 66 & 38 & 68 & 10 & 10 & 20 & 50 \\
\hline 21-Aug & 10:00 & 30 & 3.0 & 3. & 259 & 264 & 179 & 250 & 1 & 1 & 3 & 3 \\
\hline 21-Aug & 10:30 & 30 & 8.5 & $3 s$ & 441 & 483 & 519 & 464 & 10 & 10 & $3 \theta$ & 30 \\
\hline 21-Aug & 11:00 & 30 & 9.0 & $2 \mathrm{~s}$ & 420 & 588 & 643 & 512 & 1 & 2 & 2 & 2 \\
\hline 21-Aug & 11:30 & 30 & 9.5 & $2 s$ & 630 & 651 & 599 & 634 & 18 & $2 \theta$ & $2 \theta$ & $2 \theta$ \\
\hline 21-Aug & $12: 00$ & 30 & 10.0 & $1 \mathrm{~s}$ & 546 & 767 & 609 & 645 & 1 & 1 & 1 & 24 \\
\hline 21-Aug & 12:30 & 30 & 10.5 & $1 \mathrm{~s}$ & 672 & 798 & 672 & 724 & 10 & 10 & $1 \theta$ & $24 \theta$ \\
\hline 21-Aug & 13:00 & 30 & 11.0 & $2 s$ & 546 & 557 & 630 & 558 & 1 & 1 & 2 & 55 \\
\hline 21-Aug & 13:30 & 30 & 11.5 & $2 s$ & 441 & 672 & 651 & 558 & 10 & 10 & $2 \theta$ & $55 \theta$ \\
\hline 21-Aug & 14:00 & 30 & 12.0 & $1 \mathrm{~s}$ & 536 & 725 & 620 & 623 & 1 & 1 & 1 & 70 \\
\hline 21-Aug & $14: 30$ & 30 & 12.5 & $1 \mathrm{~s}$ & 611 & 685 & 683 & 649 & 10 & $1 e$ & 10 & $70 \theta$ \\
\hline 21-Aug & $15: 00$ & 30 & 13.0 & 1 & 529 & 693 & 523 & 596 & 1 & 1 & 1 & 79 \\
\hline 21-Aug & 15:30 & 30 & 13.5 & 2 & 538 & 628 & 571 & 577 & 10 & 1 e & 10 & $79 \theta$ \\
\hline 21-Aug & 16:00 & 30 & 14.0 & 1 & 210 & 386 & 402 & 303 & 1 & 1 & 2 & 58 \\
\hline 21-Aug & $16: 30$ & 30 & 14.5 & 2 & 251 & 266 & 290 & 259 & 10 & $1 \theta$ & $2 \theta$ & $58 \theta$ \\
\hline 21-Aug & 17:00 & 30 & 15.0 & 1 & 166 & 228 & 288 & 204 & 1 & 1 & 2 & 97 \\
\hline 21-Aug & 17:30 & 30 & 15.5 & 1 & 172 & 174 & 193 & 174 & 10 & 10 & $2 \theta$ & $97 \mathrm{e}$ \\
\hline 21-Aug & 18:00 & 30 & 16.0 & 1 & 122 & 108 & 116 & 114 & 1 & 1 & 2 & 389 \\
\hline 21-Aug & 18:30 & 30 & 16.5 & 2 & 107 & 73 & 79 & 88 & 10 & 10 & $2 \theta$ & $389 \theta$ \\
\hline 21-Aug & 19:00 & 30 & 17.0 & 2 & 72 & 79 & 31 & 69 & 1 & 1 & 1 & 142 \\
\hline 21-Aug & 19:30 & 30 & 17.5 & 1 & 88 & 79 & 27 & 77 & 10 & 10 & $1 \mathrm{e}$ & $142 \theta$ \\
\hline 21-Aug 2 & 20:00 & 30 & 18.0 & 2 & 92 & 59 & 29 & 69 & 1 & 1 & 2 & 139 \\
\hline 21-Aug 2 & 20:30 & 30 & 18.5 & 1 & 85 & 28 & 21 & 53 & 10 & 10 & $2 \theta$ & $139 \theta$ \\
\hline 21-Aug 2 & 21:00 & 30 & 19.0 & 1 & 67 & 24 & 18 & 43 & 1 & 1 & 2 & 162 \\
\hline 21-Aug 2 & 21:30 & 30 & 19.5 & 3 & 57 & 22 & 18 & 35 & 1 e) & $1 e$ & $2 e$ & $162 \theta$ \\
\hline 21-Aug 2 & 22:00 & 30 & 20.0 & 1 & 39 & 26 & 15 & 30 & 1 & 2 & 2 & 134 \\
\hline 21-Aug 2 & 22:30 & 30 & 20.5 & 2 & 39 & 18 & 14 & 26 & 1 e & $2 \theta$ & 20 & $134 \theta$ \\
\hline 21-Aug 2 & 23:00 & 30 & 21.0 & 1 & 39 & 16 & 12 & 25 & 1 & 1 & 2 & 106 \\
\hline 21-Aug 2 & 23:30 & 30 & 21.5 & 3 & 37 & 14 & 9 & 21 & 10 & 10 & $2 \mathrm{e}$ & $106 \theta$ \\
\hline 22-Aug & $0: 00$ & 30 & 22.0 & 2 & 24 & 12 & 8 & 15 & 1 & 2 & 2 & 78 \\
\hline
\end{tabular}


TABLE C.6 (Cont.)

\begin{tabular}{|c|c|c|c|c|c|c|c|c|c|c|c|c|}
\hline & & Time Since & & & & & & Turbidity (a) & & & & \\
\hline Date & Time & $\begin{array}{r}\text { Last Sample } \\
\text { (min.) }\end{array}$ & $\begin{array}{r}\text { Elapsed Time } \\
\text { (hours) }\end{array}$ & $\begin{array}{r}\text { Crossing } \# 7 \\
\text { Upstream }\end{array}$ & $\begin{array}{r}\text { Crossing } \$ 7 \\
600 \mathrm{t} \text { - Left }\end{array}$ & $\begin{array}{r}\text { Crossing } \# 7 \\
600 \mathrm{ft} \text { - Center }\end{array}$ & $\begin{array}{r}\text { Crossing } \$ 7 \\
600 \mathrm{ft} \text { - Right }\end{array}$ & $\begin{array}{c}\text { NET Flow } \\
\text { Weighted (b) }\end{array}$ & $\begin{array}{c}\text { At } \\
\text { Crossing \#4 }\end{array}$ & $\begin{array}{c}\text { At } \\
\text { Crossing \#5 }\end{array}$ & $\begin{array}{c}\text { At } \\
\text { Crossing \#6 }\end{array}$ & $\begin{array}{c}\mathrm{At} \\
\text { Crossing } 88\end{array}$ \\
\hline 22-Aug & $0: 30$ & 30 & 22.5 & 2 & 30 & 13 & 9 & 19 & 10 & $2 \theta$ & $2 \theta$ & 780 \\
\hline 22-Aug & $1: 00$ & 30 & 23.0 & 1 & 16 & 9 & 8 & 11 & 1 & 2 & 2 & 57 \\
\hline 22-Aug & $1: 30$ & 30 & 23.5 & 1 & 11 & 9 & 5 & 9 & 10 & 20 & $2 \theta$ & $57 \theta$ \\
\hline 22-Aug & $2: 00$ & 30 & 24.0 & 1 & 16 & 5 & 4 & 9 & 1 & 1 & 1 & 45 \\
\hline 22-Aug & $2: 30$ & 30 & 24.5 & 1 & 9 & 4 & 2 & 5 & 10 & 10 & 10 & $45 \theta$ \\
\hline 22-Aug & 3:00 & 30 & 25.0 & 1 & 18 & 3 & 2 & 9 & 1 & 1 & 2 & 33 \\
\hline 22-Aug & $3: 30$ & 30 & 25.5 & 1 & 14 & 5 & 2 & 8 & 10 & 10 & $2 \theta$ & 330 \\
\hline 22-Aug & $4: 00$ & 30 & 26.0 & 2 & 28 & 3 & 2 & 13 & 1 & 2 & 2 & 56 \\
\hline 22-Aug & $4: 30$ & 30 & 26.5 & 1 & 15 & 4 & 2 & 8 & 10 & $2 \theta$ & $2 \theta$ & $56 \theta$ \\
\hline 22-Aug & $5: 00$ & 30 & 27.0 & 1 & 8 & 3 & 2 & 4 & 1 & 1 & 2 & 29 \\
\hline 22-Aug & $5: 30$ & 30 & 27.5 & 1 & 8 & 3 & 1 & 4 & 10 & 10 & $2 \theta$ & $29 \theta$ \\
\hline 22-Aug & $6: 00$ & 30 & 28.0 & 2 & 5 & 2 & 2 & 1 & 1 & 1 & 1 & 32 \\
\hline 22-Aug & $6: 30$ & 30 & 28.5 & 1 & 9 & 2 & 2 & 4 & 10 & 10 & $1 e$ & $32 \mathrm{e}$ \\
\hline 22-Aug & $7: 00$ & 30 & 29.0 & $i$ & 5 & $i$ & 2 & 2 & 1 & 1 & 1 & 22 \\
\hline 22-Aug & $7: 30$ & 30 & 29.5 & 2 & 4 & 2 & 1 & 1 & 10 & 10 & 10 & $22 \theta$ \\
\hline 22-Aug & 8:00 & 30 & 30.0 & $11 \mathrm{~s}$ & 4 & 5 & 2 & 0 & 1 & 1 & 1 & 11 \\
\hline 22-Aug & $8: 30$ & 30 & 30.5 & $11 \mathrm{~s}$ & 26 & 34 & 12 & 17 & 10 & 10 & 10 & 110 \\
\hline 22-Aug & $9: 00$ & 30 & 31.0 & $17 \mathrm{~s}$ & 138 & 62 & 31 & 78 & 1 & 2 & 1 & 17 \\
\hline 22-Aug & $9: 30$ & 30 & 31.5 & $17 \mathrm{~s}$ & 155 & 55 & 34 & 83 & 10 & $2 \theta$ & $1 e$ & $17 \theta$ \\
\hline 22-Aug & $10: 00$ & 30 & 32.0 & $12 \mathrm{~s}$ & 231 & 48 & 33 & 121 & 1 & 1 & 1 & 12 \\
\hline 22-Aug & $10: 30$ & 30 & 32.5 & $12 \mathrm{~s}$ & 209 & $132 \mathrm{~m}$ & 54 & 148 & 10 & 10 & 10 & $12 \theta$ \\
\hline 22-Aug & $11: 00$ & 30 & 33.0 & $7 \mathrm{~s}$ & 174 & $109 \mathrm{~m}$ & 44 & 126 & 1 & 1 & 2 & 7 \\
\hline 22-Aug & $11: 30$ & 30 & 33.5 & $7 \mathrm{~s}$ & 121 & $77 \mathrm{~m}$ & 32 & 86 & 10 & $1 e$ & $2 \theta$ & $7 e$ \\
\hline 22-Aug & $12: 00$ & 30 & 340 & $8 \mathrm{~s}$ & 99 & $64 \mathrm{ml}$ & 28 & 69 & 1 & 1 & 3 & 8 \\
\hline 22-Aug & $12: 30$ & 30 & 34.5 & $8 \mathrm{~s}$ & 176 & $110 \mathrm{~m}$ & 44 & 126 & 10 & $1 \theta$ & 30 & 80 \\
\hline 22-Aug & $13: 00$ & 30 & 35.0 & 8 s & 175 & $135 \mathrm{~m}$ & 94 & 141 & 2 & 3 & 3 & 8 \\
\hline 22-Aug & $13: 30$ & 30 & 35.5 & $8 \mathrm{~s}$ & 85 & $74 \mathrm{~m}$ & 62 & 70 & $2 \theta$ & $3 \theta$ & 3 e & $8 \theta$ \\
\hline 22-Aug & $14: 00$ & 30 & 36.0 & $6 \mathrm{~s}$ & 21 & $36 \mathrm{~m}$ & 50 & 24 & 1 & 2 & 3 & 6 \\
\hline 22-Aug & $14: 30$ & 30 & 36.5 & $\begin{array}{ll}6 & \mathrm{~s}\end{array}$ & 308 & $177 \mathrm{~m}$ & 46 & 219 & 10 & 20 & 30 & $6 \theta$ \\
\hline 22-Aug & $15: 00$ & 30 & 37.0 & $14 \mathrm{~s}$ & 40 & $38 \mathrm{~m}$ & 36 & 25 & i & 3 & 2 & 14 \\
\hline 22-Aug & $15: 30$ & 30 & 37.5 & $14 \mathrm{~s}$ & 22 & $24 \mathrm{~m}$ & 26 & 9 & 10 & $3 \theta$ & $2 \theta$ & $14 \theta$ \\
\hline 22-Aug & $16: 00$ & 30 & 38.0 & $20 \mathrm{~s}$ & 15 & $16 \mathrm{~m}$ & 17 & 0 & 1 & 2 & 1 & 20 \\
\hline 22-Aug & $16: 30$ & 30 & 38.5 & $20 \mathrm{~s}$ & 13 & $10 \mathrm{~m}$ & 7 & 0 & $1 \theta$ & 20 & 10 & $20 \theta$ \\
\hline 22-Aug & $17: 00$ & 30 & 39.0 & $25 \mathrm{~s}$ & 1189 & $643 \mathrm{~m}$ & 97 & 819 & 1 & 2 & 3 & 25 \\
\hline 22-Aug & $17: 30$ & 30 & 39.5 & $25 \mathrm{~s}$ & 2452 & $1438 \mathrm{~m}$ & 424 & 1786 & 10 & $2 \theta$ & 38 & $25 \theta$ \\
\hline 22-Aug & $18: 00$ & 30 & 40.0 & $29 \mathrm{~s}$ & 3264 & $2044 \mathrm{~m}$ & 823 & 2464 & 2 & 1 & 1 & 29 \\
\hline 22-Aug & $18: 30$ & 30 & 40.5 & $29 \mathrm{~s}$ & 3078 & $1917 \mathrm{~m}$ & 756 & 2315 & $2 \theta$ & 10 & $1 e$ & $29 \theta$ \\
\hline 22-Aug & 19:00 & 30 & 41.0 & $38 \mathrm{~s}$ & 3567 & $2000 \mathrm{~m}$ & 433 & 2539 & 1 & 1 & 3 & 38 \\
\hline 22-Aug & $19: 30$ & 30 & 41.5 & 22 & $1863 \mathrm{~m}$ & 1632 & 2093 & 1768 & 10 & 10 & $3 \mathrm{e}$ & 380 \\
\hline 22-Aug & $20: 00$ & 30 & 42.0 & 6 & $839 \mathrm{~m}$ & 779 & 899 & 814 & 2 & 3 & 3 & 27 \\
\hline 22-Aug? & $20: 30$ & 30 & 42.5 & 10 & $450 \mathrm{~m}$ & 655 & 244 & 504 & $2 \theta$ & 30 & $3 \mathrm{e}$ & $27 \theta$ \\
\hline 22-Aug & $21: 00$ & 30 & 43.0 & 12 & $104 \mathrm{~m}$ & 126 & 81 & 99 & 1 & 2 & 2 & 18 \\
\hline 22-Aug ? & $21: 30$ & 30 & 43.5 & 51 & $35 \mathrm{~m}$ & 35 & 35 & 0 & 10 & $2 \theta$ & $2 \theta$ & $18 \theta$ \\
\hline 22-Aug? & 22:00 & 30 & 44.0 & 8 & $25 \mathrm{~m}$ & 33 & 17 & 20 & 2 & 3 & 2 & 25 \\
\hline 22-Aug? & $22: 30$ & 30 & 44.5 & 5 & $16 \mathrm{~m}$ & 22 & 10 & 13 & $2 \mathrm{e}$ & 3 e & $2 \theta$ & 25 e \\
\hline
\end{tabular}


TABLE C.6 (Cont.)

\begin{tabular}{|c|c|c|c|c|c|c|c|c|c|c|c|c|}
\hline \multirow[b]{2}{*}{ Date } & \multicolumn{3}{|c|}{ Time Since } & \multicolumn{9}{|c|}{ Turbidity (a) } \\
\hline & Time & $\begin{array}{r}\text { Last Sample } \\
\text { (min.) }\end{array}$ & $\begin{array}{r}\begin{array}{r}\text { Elapsed Time } \\
\text { (hours) }\end{array} \\
\end{array}$ & $\begin{array}{r}\text { Crossing } \$ 7 \\
\text { Upstream }\end{array}$ & $\begin{array}{l}\text { Crossing } 17 \\
600 \mathrm{ft}-\text { Leht }\end{array}$ & $\begin{array}{r}\text { Crossing } \# 7 \\
600 \mathrm{t} \text { - Center }\end{array}$ & $\begin{array}{r}\text { Crossing } \sharp 7 \\
600 \mathrm{n}-\text { Pight } \\
\end{array}$ & $\begin{array}{c}\text { NET Flow } \\
\text { Weighted (b) }\end{array}$ & $\begin{array}{c}\text { At } \\
\text { Crossing \#4 }\end{array}$ & $\begin{array}{c}\text { At } \\
\text { Crossing } \# 5\end{array}$ & $\begin{array}{c}\text { A1 } \\
\text { Crossing \#6 }\end{array}$ & $\begin{array}{c}\text { At } \\
\text { Crossing } \because 8\end{array}$ \\
\hline 22-Aug & 23:00 & 30 & 45.0 & 2 & $16 \mathrm{~m}$ & 17 & 15 & 14 & 1 & 2 & 2 & 191 \\
\hline 22-Aug & 23:30 & 30 & 45.5 & 10 & $10 \mathrm{~m}$ & 16 & 3 & 2 & 10 & 2 of & 2 e & 1910 \\
\hline 23-Aug & $0: 00$ & 30 & 46.0 & 14 & $9 \mathrm{~m}$ & 12 & 6 & 0 & 1 & 2 & 3 & 536 \\
\hline 23-Aug & $0: 30$ & 30 & 46.5 & 98 & $11 \mathrm{~m}$ & 11 & 11 & 0 & $1 \theta$ & $2 \theta$ & 3 e & $536 e$ \\
\hline 23-Aug & $1: 00$ & 30 & 47.0 & 10 & $10 \mathrm{~m}$ & 13 & 6 & 1 & 1 & 2 & 2 & 741 \\
\hline 23-Aug & $1: 30$ & 30 & 47.5 & 10 & $10 \mathrm{~m}$ & 12 & 7 & 0 & 10 & 2 e) & $2 \theta$ & $741 \theta$ \\
\hline 23-Aug & $2: 00$ & 30 & 48.0 & 14 & $8 \mathrm{~m}$ & 10 & 6 & 0 & 1 & 2 & 2 & 779 \\
\hline 23-Aug & $2: 30$ & 30 & 48.5 & 16 & $8 \mathrm{~m}$ & 9 & 6 & 0 & 10 & 2 o & $2 \theta$ & $779 \theta$ \\
\hline 23-Aug & 3:00 & 30 & 49.0 & 21 & $6 \mathrm{~m}$ & 6 & 6 & 0 & 1 & 2 & 2 & 428 \\
\hline 23-Aug & $3: 30$ & 30 & 49.5 & 10 & $6 \mathrm{~m}$ & 7 & 5 & 0 & 10 & $2 \theta$ & 20 & $428 \theta$ \\
\hline 23-Aug & 4:00 & 30 & 50.0 & 14 & $6 \mathrm{~m}$ & 5 & 6 & 0 & 1 & 1 & 2 & 363 \\
\hline 23-Aug & $4: 30$ & 30 & 50.5 & 7 & $6 \mathrm{~m}$ & 8 & 3 & 0 & 10 & 10 & 20 & $363 \theta$ \\
\hline 23-Aug & $5: 00$ & 30 & 51.0 & 12 & $5 \mathrm{~m}$ & 6 & 4 & 0 & 1 & 2 & 1 & 111 \\
\hline 23-Aug & $5: 30$ & 30 & 51.5 & 8 & $5 \mathrm{~m}$ & 6 & 4 & 0 & 10 & 2 e & 10 & 1110 \\
\hline 23-Aug & $6: 00$ & 30 & 52.0 & 16 & $5 \mathrm{~m}$ & 6 & 4 & 0 & 2 & 1 & 4 & 68 \\
\hline 23-Aug & $6: 30$ & 30 & 52.5 & 9 & $4 \mathrm{~m}$ & 5 & 3 & 0 & $2 \theta$ & 10 & 40 & 680 \\
\hline 23-Aug & $7: 00$ & 30 & 53.0 & 9 & $4 \mathrm{~m}$ & 5 & 3 & 0 & 1 & 1 & 2 & 47 \\
\hline 23-Aug & $8: 00$ & 60 & 54.0 & stopped & stopped & 4 & stopped & of & 1 & 1 & 2 & 47 \\
\hline 23-Aug & $9: 00$ & 60 & 55.0 & & & 4 & & $0 \mathrm{t}$ & 1 & 1 & 2 & 39 \\
\hline 23-Aug & $10: 00$ & 60 & 56.0 & & & 4 & & 01 & 2 & 1 & 2 & 16 \\
\hline 23-Aug & $11: 00$ & 60 & 57.0 & & & 3 & & 01 & 2 & 1 & 2 & 14 \\
\hline 23-Aug & 12:00 & 60 & 58.0 & & & 4 & & 01 & 1 & 1 & 1 & 11 \\
\hline 23-Aug & 13:00 & 60 & 59.0 & & & 3 & & of & 1 & 1 & 2 & 13 \\
\hline 23-Aug & $14: 00$ & 60 & 60.0 & & & 4 & & of & 1 & 1 & 1 & 8 \\
\hline 23-Aug & 15:00 & 60 & 61.0 & & & 4 & & of & 2 & 2 & 1 & 9 \\
\hline 23-Aug & $16: 00$ & 60 & 62.0 & & & 4 & & of & 2 & 1 & 1 & 9 \\
\hline 23-Aug & $17: 00$ & 60 & 63.0 & & & 3 & & of & 2 & 1 & 2 & 8 \\
\hline 23-Aug & $18: 00$ & 60 & 64.0 & & & 3 & & 01 & 2 & 3 & 2 & 9 \\
\hline 23-Aug & $19: 00$ & 60 & 65.0 & & & 3 & & of & 1 & 1 & 2 & 7 \\
\hline 23-Aug & 20:00 & 60 & 66.0 & & & 3 & & of & 1 & 2 & 1 & 7 \\
\hline 23-Aug & 21:00 & 60 & 67.0 & & & 18 & & $0 f$ & 1 & 2 & 2 & 7 \\
\hline 23-Aug & 22:00 & 60 & 68.0 & & & 3 & & of & 2 & 2 & 1 & 8 \\
\hline 23-Aug & 23:00 & 60 & 69.0 & & & 3 & & 01 & 2 & 2 & 2 & 77 \\
\hline 24-Aug & $0: 00$ & 60 & 70.0 & & & 2 & & of & 1 & 1 & 3 & 8 \\
\hline 24-Aug & $1: 00$ & 60 & 71.0 & & & 4 & & of & 2 & 2 & 2 & 8 \\
\hline 24-Aug & $2: 00$ & 60 & 72.0 & & & 3 & & of & 2 & 1 & 2 & 8 \\
\hline 24-Aug & 3:00 & 60 & 73.0 & & & 5 & & 01 & 1 & 1 & 2 & 7 \\
\hline 24-Aug & $4: 00$ & 60 & 74.0 & & & 3 & & $0 \mathrm{f}$ & 1 & 2 & 2 & 6 \\
\hline 24-Aug & $5: 00$ & 60 & 75.0 & & & 2 & & $0 t$ & 1 & 1 & 1 & 5 \\
\hline 24-Aug & $6: 00$ & 60 & 76.0 & & & 2 & & of & 1 & 1 & 1 & 5 \\
\hline 24-Aug & $7: 00$ & 60 & 77.0 & & & 2 & & of & 1 & 2 & 2 & 6 \\
\hline 24-Aug & 8:00 & 60 & 78.0 & & & 1 & & $0 \mathrm{f}$ & 1 & 1 & 2 & 4 \\
\hline 24-Aug & $9: 00$ & 60 & 79.0 & & & 1 & & $0 \mathrm{f}$ & 49 & 2 & 2 & 5 \\
\hline 24-Aug & $10: 00$ & 60 & 80.0 & & & 1 & & of & 3 & $2 \pi$ & 1 & 3 \\
\hline 24-Aug & $11: 00$ & 60 & 81.0 & & & 1 & & of & 1 & 1 & 1 & 2 \\
\hline
\end{tabular}


TABLE C.6 (Cont.)

Time Since

\begin{tabular}{|c|c|c|c|c|c|c|c|c|c|c|c|c|}
\hline Date & Time & $\begin{array}{r}\text { Last Sample } \\
\text { (min.) }\end{array}$ & $\begin{array}{r}\text { Elapsed Time } \\
\text { (hours) }\end{array}$ & $\begin{array}{r}\text { Crossing } \# 7 \\
\text { Upstream }\end{array}$ & $\begin{array}{l}\text { Crossing } \$ 7 \\
600 \mathrm{tt} \text { - Left }\end{array}$ & $\begin{array}{r}\text { Crossing } \$ 7 \\
600 \mathrm{ft} \text { - Center }\end{array}$ & $\begin{array}{r}\text { Crossing } \$ 7 \\
600 \mathrm{ft}-\text { Right }\end{array}$ & \begin{tabular}{|c|} 
NET Flow \\
Weighted (b)
\end{tabular} & $\begin{array}{c}\text { At } \\
\text { Crossing } \# 4\end{array}$ & $\begin{array}{c}\text { At } \\
\text { Crossing *5 }\end{array}$ & $\begin{array}{c}\text { Al } \\
\text { Crossing \#6 }\end{array}$ & $\begin{array}{c}\text { Al } \\
\text { Crossing } \# 8\end{array}$ \\
\hline 24-Aug & 12:00 & 60 & 82.0 & & & 1 & & 01 & 1 & 4 & 2 & $\overline{2}$ \\
\hline 24-Aug & 13:00 & 60 & 83.0 & & & 1 & & of & 1 & 4 & $!$ & 1 \\
\hline 24-Aug & $14: 00$ & 60 & 84.0 & & & 5 & & of & 1 & 2 & 1 & 4 \\
\hline 24-Aug & $15: 00$ & 60 & 85.0 & & & 4 & & of & 1 & 3 & 5 & 11 \\
\hline 24-Aug & $16: 00$ & 60 & 86.0 & & & 3 & & of & 1 & 8 & 2 & 37 \\
\hline 24-Aug & $17: 00$ & 60 & 87.0 & & & 4 & & of & 1 & 11 & 2 & 67 \\
\hline 24-Aug & $18: 00$ & 60 & 88.0 & & & 4 & & of & 1 & 10 & 3 & 13 \\
\hline 24-Aug & 19:00 & 60 & 89.0 & & & 3 & & of & 1 & 9 & 8 & 4 \\
\hline 24-Aug & $20: 00$ & 60 & 90.0 & & & 4 & & of & 1 & 5 & 9 & 7 \\
\hline 24-Aug & $21: 00$ & 60 & 91.0 & & & 7 & & of & 1 & 3 & 7 & 4 \\
\hline 24-Aug & $22: 00$ & 60 & 92.0 & & & 9 & & of & 1 & 2 & 6 & 4 \\
\hline 24-Aug & $23: 00$ & 60 & 93.0 & & & 8 & & of & 1 & 3 & 4 & 5 \\
\hline 25-Aug & $0: 00$ & 60 & 94.0 & & & 8 & & of & 1 & 2 & 3 & 5 \\
\hline 25-Aug & $1: 00$ & 60 & 95.0 & & & 5 & & of & 1 & 2 & 2 & 5 \\
\hline 25-Aug & $2: 00$ & 60 & 96.0 & & & 4 & & of & 1 & 1 & 2 & 5 \\
\hline 25-Aug & 3:00 & 60 & 97.0 & & & 2 & & of & 1 & 1 & 1 & 6 \\
\hline 25-Aug & $4: 00$ & 60 & 98.0 & & & 4 & & of & 1 & 1 & 1 & 8 \\
\hline 25-Aug & $5: 00$ & 60 & 99.0 & & & 2 & & of & 1 & 1 & 1 & 8 \\
\hline 25-Aug & $6: 00$ & 60 & 100.0 & & & 1 & & 01 & 1 & 1 & 1 & 7 \\
\hline 25-Aug & $7: 00$ & 60 & 101.0 & & & 1 & & of & 1 & 1 & 1 & 7 \\
\hline 25-Aug & $8: 00$ & 60 & 102.0 & & & 3 & & of & 2 & 1 & 1 & 6 \\
\hline 25-Aug & 9:00 & 60 & 103.0 & & & 5 & & of & 1 & 2 & 1 & 36 \\
\hline 25-Aug & $10: 00$ & 60 & 104.0 & & & 4 & & $0 \mathrm{f}$ & $1 \mathrm{~m}$ & 4 & 4 & 29 \\
\hline 25-Aug & 11:00 & 60 & 105.0 & & & 4 & & 01 & 1 & 13 & 2 & 4 \\
\hline 25-Aug & $12: 00$ & 60 & 106.0 & & & 3 & & of & 1 & 20 & 5 & 3 \\
\hline 25-Aug & 13:00 & 60 & 107.0 & & & 4 & & $0 f$ & 1 & 16 & 3 & 2 \\
\hline 25-Aug & $14: 00$ & 60 & 108.0 & & & 4 & & $0 \mathrm{f}$ & 1 & 12 & 4 & 3 \\
\hline 25-Aug & $15: 00$ & 60 & 109.0 & & & 6 & & $0 \mathrm{f}$ & 2 & 23 & 8 & 3 \\
\hline 25-Aug & $16: 00$ & 60 & 110.0 & & & 8 & & of & 1 & 10 & 12 & 2 \\
\hline 25-Aug & $17: 00$ & 60 & 111.0 & & & 11 & & $0 \mathrm{f}$ & 1 & 18 & 13 & 3 \\
\hline 25-Aug & 18:00 & 60 & 112.0 & & & 12 & & of & 1 & 9 & 22 & 2 \\
\hline
\end{tabular}

(a) $m=$ sample missed/value is extrapolated;

$\theta=$ measurement from previous samples are extrapolated for graphing purposes

$s=$ Sampler upstream at 7 tipped over. Sampler at crossing 6 downstream used for this data.

$f=$ after the upstream sampler is removed the NET flow weighted turbidity is assumed to be zero (for the purposes of calculating the 10 day running average of NET flow weighted turbidity only)

(b) Note: If the upstream turbidity reading was higher than the simultaneous downstream reading, net turbidity was equal

to 0 . Also, after the upstream sampler was removed, all subsequent net turbidity values were assumed to be zero.

Total Net Downstream Flow-Welghted NTU'hours =

12772 
TABLE C.7 Turbidity Generated by Crossing \#2

Time Since

Turbidity (a)

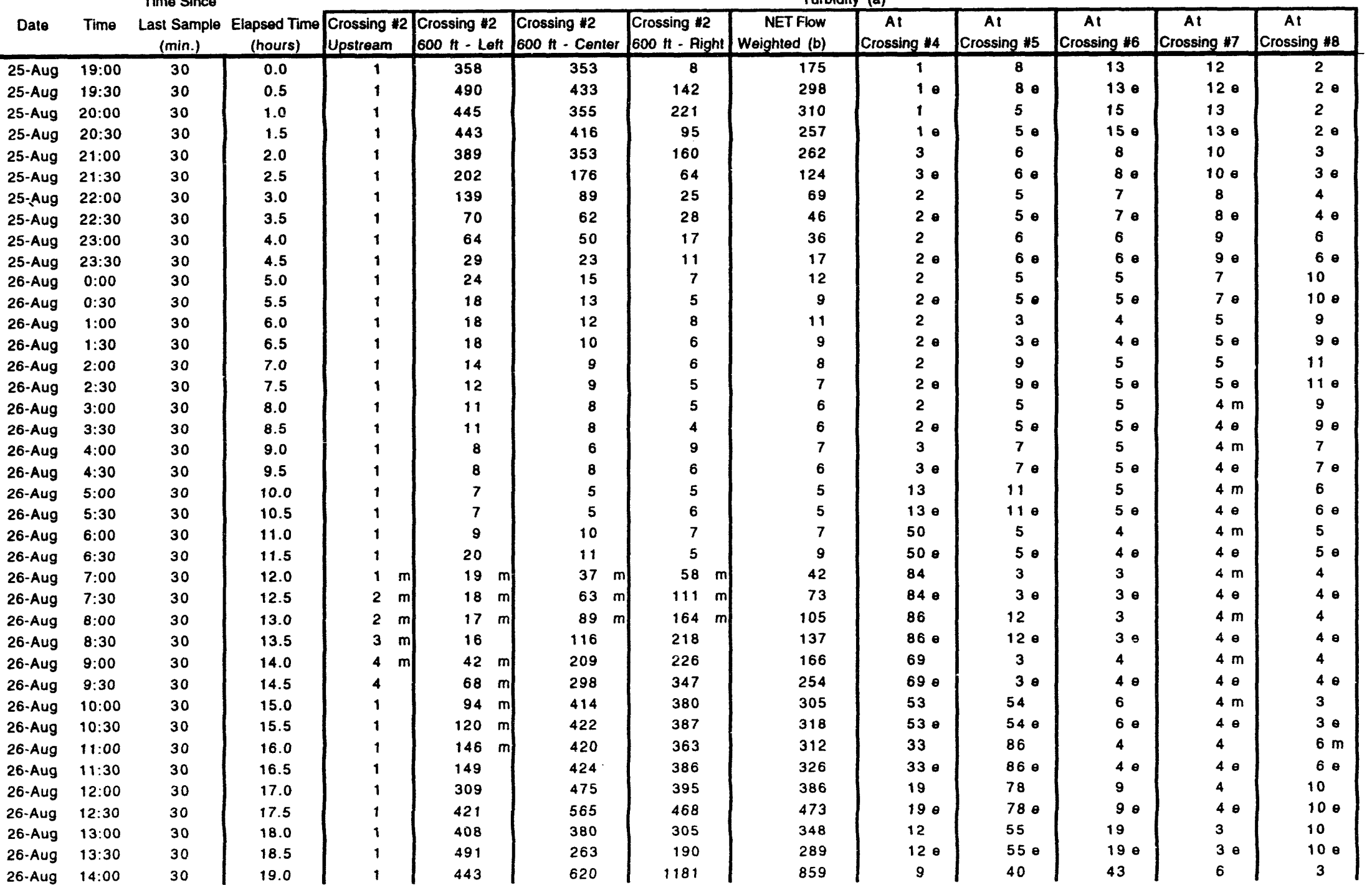




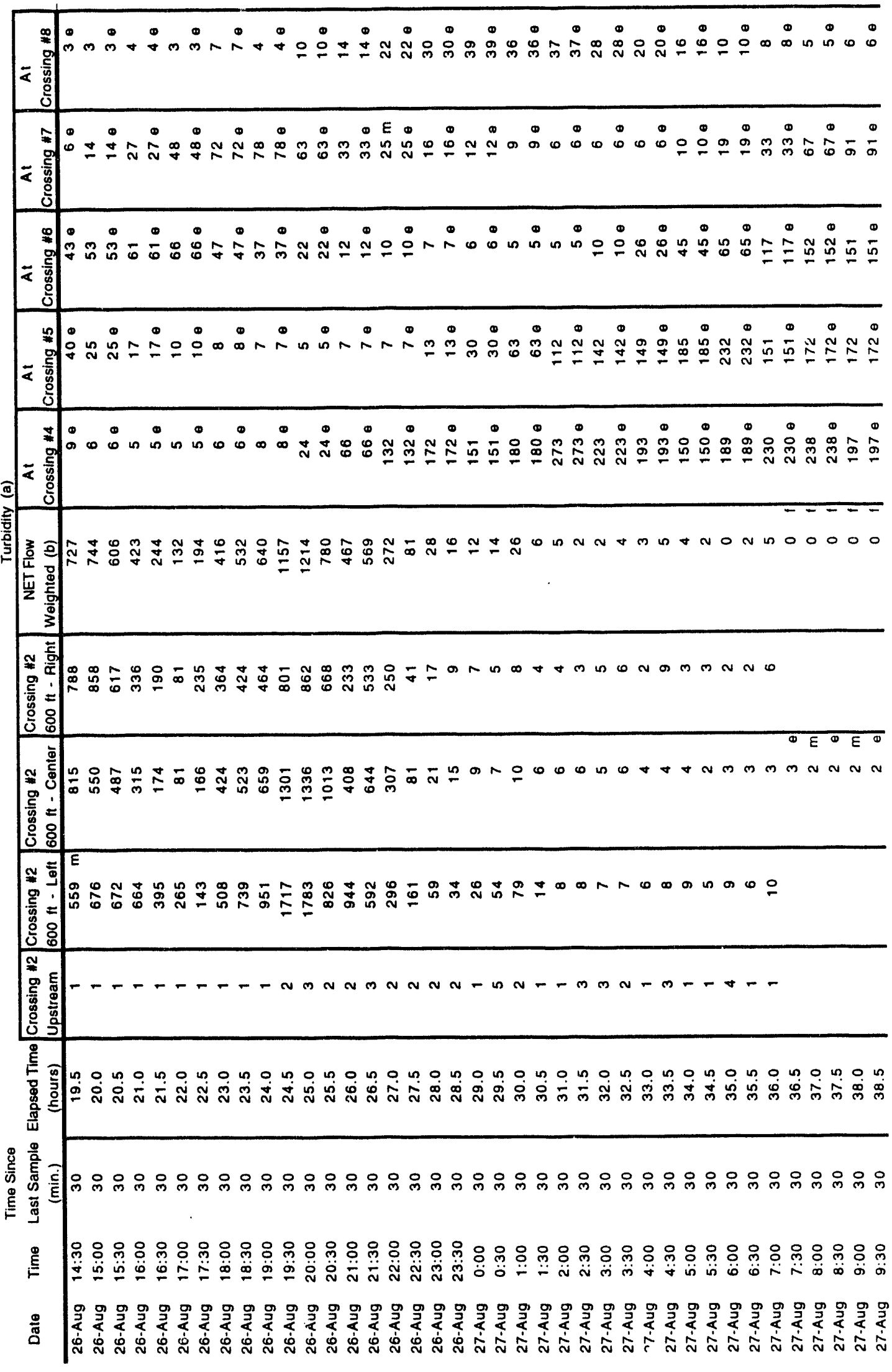


TABLE C.7 (Cont.)

Time Since

\begin{tabular}{|c|c|c|c|c|c|c|c|c|c|c|c|c|c|}
\hline \multirow[b]{2}{*}{ Date } & \multicolumn{3}{|c|}{ Time Since } & \multicolumn{10}{|c|}{ Turbidity (a) } \\
\hline & Time & $\begin{array}{l}\text { Last Sample } \\
\text { (min.) }\end{array}$ & $\begin{array}{l}\text { Elapsed Time } \\
\text { (hours) }\end{array}$ & $\begin{array}{l}\text { Crossing "12 } \\
\text { Upstream }\end{array}$ & $\begin{array}{l}\text { Crossing \#2 } \\
600 \mathrm{t}-\text { Left }\end{array}$ & $\begin{array}{l}\text { Crossing } \# 2 \\
600 \mathrm{t} \text { - Center }\end{array}$ & \begin{tabular}{|l|} 
Crossing \#2 \\
$600 \mathrm{ft}$ - Right
\end{tabular} & $\begin{array}{r}\text { NET Flow } \\
\text { Weighted (b) }\end{array}$ & $\begin{array}{c}\text { At } \\
\text { Crossing } * 4\end{array}$ & $\begin{array}{c}\text { At } \\
\text { Crossing } * 5\end{array}$ & $\begin{array}{c}\text { At } \\
\text { Crossing } \because 6\end{array}$ & $\begin{array}{c}\text { At } \\
\text { Crossing } \because 7\end{array}$ & $\begin{array}{c}A t \\
\text { Crossing } \# 8\end{array}$ \\
\hline 27-Aug & $10: 00$ & 30 & 39.0 & & & 1 & & 0 & 103 & 174 & 112 & 122 & 7 \\
\hline 27-Aug & $10: 30$ & 30 & 39.5 & & & 10 & & 0 & 1038 & $174 \theta$ & $112 \theta$ & $122 \theta$ & $7 e$ \\
\hline 27-Aug & $11: 30$ & 30 & 40.5 & & & 10 & & 0 & 700 & $143 \theta$ & 1100 & $96 \theta$ & $10 \theta$ \\
\hline 27-Aug & $12: 00$ & 30 & 41.0 & & & 1 & & 0 & 39 & 120 & 101 & 98 & 18 \\
\hline 27-Aug & $12: 30$ & 30 & 41.5 & & & 10 & & 0 & 390 & $120 \theta$ & $101 \theta$ & $98 \theta$ & $18 \theta$ \\
\hline 27-Aug & 13:00 & 30 & 42.0 & & & 11 & & 0 & 20 & 95 & 91 & 108 & 32 \\
\hline 27-Aug & $13: 30$ & 30 & 42.5 & & & $11 \theta$ & $\theta$ & 0 & $20 \theta$ & 950 & 910 & $108 \theta$ & $32 \theta$ \\
\hline 27-Aug & $14: 00$ & 30 & 43.0 & & & 20 & & 0 & 11 & 86 & 102 & 100 & 45 \\
\hline 27-Aug & $14: 30$ & 30 & 43.5 & & & $20 \theta$ & & 0 & $11 \mathrm{e}$ & 860 & $102 \theta$ & $100 \theta$ & 450 \\
\hline 27-Aug & $15: 00$ & 30 & 44.0 & & & 12 & & 0 & 9 & 54 & 109 & 120 & 61 \\
\hline 27-Aug & $15: 30$ & 30 & 44.5 & & & $12 \theta$ & & 0 & 90 & $54 \theta$ & $109 \theta$ & $120 \theta$ & 610 \\
\hline 27-Aug & $16: 00$ & 30 & 45.0 & & & 5 & & 0 & 6 & 29 & 112 & 110 & 68 \\
\hline 27-Aug & $16: 30$ & 30 & 45.5 & & & 50 & & 0 & 60 & 290 & $112 \theta$ & $110 \theta$ & $68 \theta$ \\
\hline 27-Aug & $17: 00$ & 30 & 46.0 & & & 3 & & 0 & 5 & 20 & 100 & 114 & 78 \\
\hline 27-Aug & $17: 30$ & 30 & 46.5 & & & $\begin{array}{ll}3 & 0\end{array}$ & & 0 & 50 & 200 & $100 \theta$ & $114 \theta$ & 780 \\
\hline 27-Aug & $18: 00$ & 30 & 47.0 & & & 3 & & 0 & 5 & 11 & 69 & 93 & 89 \\
\hline 27-Aug & $18: 30$ & 30 & 47.5 & & & 30 & & 0 & 50 & $11 \theta$ & $69 \theta$ & 930 & $89 \theta$ \\
\hline 27-Aug & $19: 30$ & 30 & 48.5 & & & 20 & & 0 & $4 \theta$ & 80 & 680 & $101 \theta$ & 910 \\
\hline 27-Aug & $20: 00$ & 30 & 49.0 & & & 5 & & 0 & 4 & 7 & 51 & 72 & 83 \\
\hline 27-Aug & $20: 30$ & 30 & 49.5 & & & 50 & & 0 & 40 & $7 \theta$ & $51 \theta$ & $72 \theta$ & $83 \theta$ \\
\hline 27-Aug & $21: 00$ & 30 & 50.0 & & & 3 & & 0 & 3 & 6 & 24 & 61 & 86 \\
\hline 27-Aug & $21: 30$ & 30 & 50.5 & & & $\begin{array}{ll}3 & 0\end{array}$ & & 0 & 30 & 60 & $24 \theta$ & 610 & $86 \theta$ \\
\hline 27-Aug & $22: 00$ & 30 & 51.0 & & & 2 & & 0 & 3 & 5 & 14 & 46 & 84 \\
\hline 27-Aug & $22: 30$ & 30 & 51.5 & & & 20 & & 0 & 30 & $5 \theta$ & $14 \theta$ & $46 \theta$ & $84 \mathrm{e}$ \\
\hline 27-Aug & 23:00 & 30 & 52.0 & & & 2 & & 0 & 4 & 6 & 10 & 23 & 89 \\
\hline 27-Aug & 23:30 & 30 & 52.5 & & & 20 & & 0 & $4 \theta$ & $6 \theta$ & $10 \theta$ & $23 \theta$ & $89 \mathrm{~A}$ \\
\hline 28-Aug & $0: 00$ & 30 & 53.0 & & & 2 & & 0 & 6 & 4 & 7 & 16 & 86 \\
\hline 28-Aug & $0: 30$ & 30 & 53.5 & & & 20 & & 0 & 60 & $4 \theta$ & 70 & $16 \theta$ & $86 \theta$ \\
\hline 28-Aug & $1: 00$ & 30 & 54.0 & & & 2 & & 0 & 8 & 4 & 5 & 11 & 83 \\
\hline 28-Aug & $1: 30$ & 30 & 54.5 & & & $\begin{array}{ll}2 & 0\end{array}$ & & 0 & 80 & $4 \theta$ & $5 \theta$ & $11 \theta$ & 830 \\
\hline 28-Aug & 2:00 & 30 & 55.0 & & & 2 & & 0 & 5 & 4 & 4 & 8 & 72 \\
\hline 28-Aug & $2: 30$ & 30 & 55.5 & & & 20 & & 0 & 50 & $4 \theta$ & 40 & 80 & $72 \theta$ \\
\hline 28-Aug & $3: 00$ & 30 & 56.0 & & & 2 & - & 0 & 5 & 5 & 4 & 7 & 53 \\
\hline 28-Aug & $3: 30$ & 30 & 56.5 & & & 20 & & 0 & $5 \theta$ & $5 \theta$ & 40 & 70 & $53 \theta$ \\
\hline 28-Aug & 4:00 & 30 & 57.0 & & & 1 & & 0 & 4 & 6 & 3 & 7 & 41 \\
\hline 28-Aug & $4: 30$ & 30 & 57.5 & & & $\begin{array}{ll}1 & e\end{array}$ & & 0 & $4 \theta$ & $6 \theta$ & $3 \theta$ & 70 & 410 \\
\hline 28-Aug & $5: 00$ & 30 & 58.0 & & & 1 & & 0 & 3 & 6 & 4 & 5 & 32 \\
\hline
\end{tabular}


TABLE C.7 (Cont.)

Time Since

\begin{tabular}{|c|c|c|c|c|c|c|c|c|c|c|c|c|c|}
\hline \multirow[b]{2}{*}{ Date } & \multicolumn{3}{|c|}{ Time Since } & \multicolumn{10}{|c|}{ Turbidity (a) } \\
\hline & Time & $\begin{array}{l}\text { Last Sample } \\
\text { (min.) }\end{array}$ & $\begin{array}{c}\text { Elapsed Time } \\
\text { (hours) }\end{array}$ & $\begin{array}{l}\text { Crossing \#2 } \\
\text { Upstream }\end{array}$ & $\begin{array}{l}\text { Crossing "2 } \\
600 \mathrm{tt}-\text { Left }\end{array}$ & $\begin{array}{l}\text { Crossing } \# 2 \\
600 \mathrm{tt} \text { - Center }\end{array}$ & $\begin{array}{l}\text { Crossing " } 2 \\
600 \mathrm{ft} \text { - Right }\end{array}$ & $\begin{array}{r}\text { NET Flow } \\
\text { Weighted (b) }\end{array}$ & $\begin{array}{c}\text { At } \\
\text { Crossing } \# 4\end{array}$ & $\begin{array}{c}\text { At } \\
\text { Crossing } 45\end{array}$ & $\begin{array}{c}\text { At } \\
\text { Crossing } \because 6\end{array}$ & $\begin{array}{c}\text { At } \\
\text { Crossing \#7 }\end{array}$ & $\begin{array}{c}\text { At } \\
\text { Crossing } \# 8\end{array}$ \\
\hline 28-Aug & $5: 30$ & 30 & 58.5 & & & 1 & & 0 & 30 & $6 \theta$ & $4 \theta$ & 58 & $32 \theta$ \\
\hline 28-Aug & $6: 00$ & 30 & 59.0 & & & 1 & & 0 & 3 & 6 & 4 & 5 & 23 \\
\hline
\end{tabular}

(a) $\mathrm{m}=$ sample missed Nalue extrapolated

$\theta=$ measurements from previous samples are extrapolated for graphing purposes only

$t=$ atter the Lpstream sampler is removed, the NET flow weighted turbidity is assumed to be zero

(for purposes of calculating the 10 day average of NET flow weighted turbidity only)

(b) Note: If the upstream turbidity reading was higher than the simultaneous downstream reading, net turbidity was equal

to 0 . Also, after the upsteam sampler was removed, all subsequent net turbidity values were assumed to be zero.

Total Net Downstream Flow-Welghted NTU*hours $=\mathbf{7 7 1 5}$ 


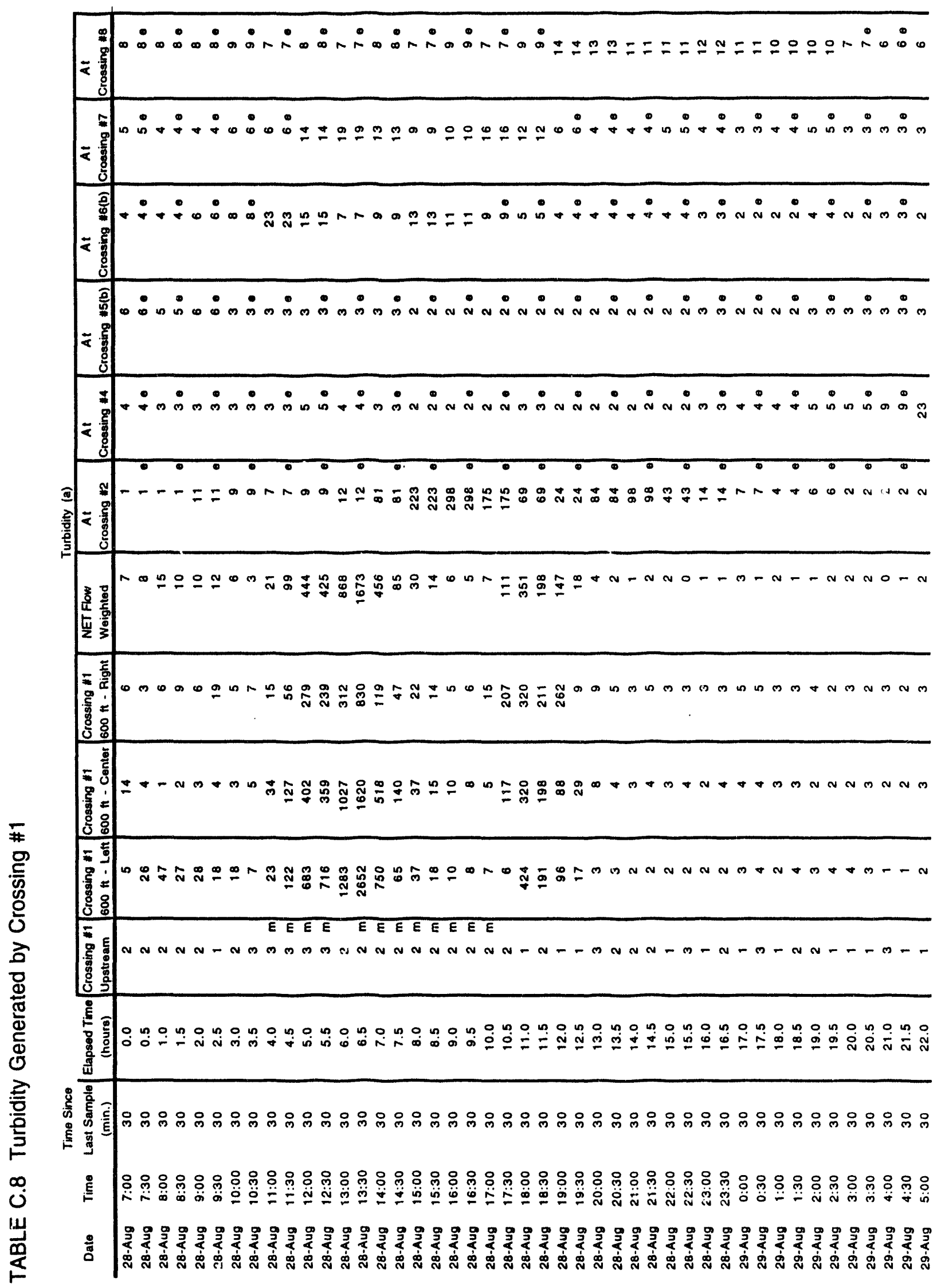


TABLE C.8 (Cont.)

\begin{tabular}{|c|c|c|c|c|c|c|c|c|c|c|c|c|c|c|}
\hline \multirow[b]{2}{*}{ Date } & \multicolumn{3}{|c|}{ Time Since } & \multicolumn{11}{|c|}{ Turbidity (a) } \\
\hline & Time & $\begin{array}{c}\text { Last Samplo } \\
\text { (min.) }\end{array}$ & $\begin{array}{c}\text { Elapsed Time } \\
\text { (hours) }\end{array}$ & $\begin{array}{l}\text { Crossing } 11 \\
\text { Upstream }\end{array}$ & $\begin{array}{l}\text { Crossing } 11 \\
600 \mathrm{ft} \text { - Left }\end{array}$ & $\begin{array}{l}\text { Crossing "1 } \\
600 \mathrm{H} \text { - Conter }\end{array}$ & $\begin{array}{l}\text { Crossing :1 } \\
600 \mathrm{tt} \text { - Right }\end{array}$ & $\begin{array}{l}\text { NET Flow } \\
\text { Woighted }\end{array}$ & $\begin{array}{c}\text { At } \\
\text { Crossing } 22\end{array}$ & $\begin{array}{c}\text { At } \\
\text { Croseing } 44\end{array}$ & $\begin{array}{c}\text { At } \\
\text { Crossing } * 5(b)\end{array}$ & $\begin{array}{c}\text { At } \\
\text { Crossing } 16(b)\end{array}$ & $\begin{array}{c}\text { At } \\
\text { Crossing } \# 7\end{array}$ & $\begin{array}{c}\text { At } \\
\text { Crossing } \# 8\end{array}$ \\
\hline 29-Aug & $5: 30$ & 30 & 22.5 & 1 & 1 & 2 & 2 & 1 & 20 & 230 & $3 \cdot$ & 20 & 3. & 60 \\
\hline 29-Aug & $6: 00$ & 30 & 23.0 & 1 & 1 & 2 & 2 & 1 & 2 & 44 & 3 & 3 & 3 & 5 \\
\hline 29-Aug & $6: 30$ & 30 & 23.5 & 2 & 1 & 2 & 1 & 0 & 20 & 440 & 3 . & $3 \bullet$ & $3 \cdot$ & 5. \\
\hline 29-Aug & $7: 00$ & 30 & 24.0 & 1 & 2 & 2 & 4 & 2 & 1 & 57 & 4 & 2 & 4 & 5 \\
\hline 29-Aug & $7: 30$ & 30 & 24.5 & 1 & 2 & 2 & 3 & 1 & $1 \cdot$ & 570 & 4. & 20 & 40 & 50 \\
\hline 29-Aug & $8: 00$ & 30 & 25.0 & 1 & 3 & 1 & 1 & 1 & 3 & 58 & 7 & 3 & 3 & 5 \\
\hline 29-Aug & $8: 30$ & 30 & 25.5 & 1 & 1 & 4 & 4 & 2 & 3. & $588^{\circ}$ & $7 \bullet$ & $3 \cdot$ & 3. & 5. \\
\hline 29-Aug & 9:00 & 30 & 26.0 & 1 & 60 & 72 & 61 & 64 & 2 & 56 & 14 & 3 & 47 & 4 \\
\hline 29-Aug & $9: 30$ & 30 & 26.5 & 1 & 57 & 59 & 24 & 46 & 20 & $56 \circ$ & 140 & $3 \bullet$ & 47 & 4. \\
\hline 29-Aug & $10: 00$ & 30 & 27.0 & 1 & 52 & 39 & 19 & 35 & 2 & 40 & 26 & 4 & 11 & 4 \\
\hline 29-Aug & $10: 30$ & 30 & 27.5 & 2 & 121 & 191 & 78 & 131 & 20 & 400 & $26 \bullet$ & 40 & 11 & 40 \\
\hline 29-Aug & 11:00 & 30 & 28.0 & 1 & 78 & 97 & 27 & 67 & 13 & 221 & 41 & 4 & 8 & 3 \\
\hline 29-Aug & $11: 30$ & 30 & 28.5 & 1 & 45 & 65 & 40 & 50 & $13 \theta$ & 2210 & $41 \bullet$ & 40 & 80 & 3 . \\
\hline 29-Aug & $12: 00$ & 30 & 29.0 & 1 & 67 & 45 & 32 & 46 & 18 & 168 & 47 & 5 & 5 & 4 \\
\hline 29-Aug & $12: 30$ & 30 & 29.5 & 1 & 9 & 15 & 6 & 9 & 180 & 1660 & 47. & 5. & 50 & 4. \\
\hline 29-Aug & 13:00 & 30 & 30.0 & 1 & 1 & 4 & 5 & 2 & 24 & 116 & 63 & 11 & 5 & 4 \\
\hline 29-Aug & $13: 30$ & 30 & 30.5 & 1 & 4 & 6 & 8 & 5 & 240 & 1160 & 630 & 110 & 50 & 40 \\
\hline 29-Aug & 14:00 & 30 & 31.0 & 2 & 2 & 4 & 7 & 2 & 34 & 41 & 40 & 23 & 10 & 4 \\
\hline 29-Aug & $14: 30$ & 30 & 31.5 & 1 & 5 & 30 & 58 & 31 & $34 \theta$ & 410 & 40 & 230 & $10 \theta$ & 40 \\
\hline 29-Aug & $15: 00$ & 30 & 32.0 & 2 & 31 & 11 & 11 & 15 & 13 & 23 & 44 & 20 & 8 & 6 \\
\hline 29-Aug & $15: 30$ & 30 & 32.5 & 2 & 87 & 11 & 76 & 53 & 130 & 230 & $44^{\circ}$ & 20 & 8. & 60 \\
\hline 29-Aug & $16: 00$ & 30 & 33.0 & 1 & 134 & 35 & 222 & 126 & 6 & 21 & 66 & 29 & 18 & 6 \\
\hline 29-Aug & $16: 30$ & 30 & 33.5 & 2 & 31 & 35 & 172 & 77 & 60 & 210 & 660 & 298 & 180 & 60 \\
\hline 29-Aug & $17: 00$ & 30 & 34.0 & 2 & 25 & 30 & 29 & 26 & 10 & 20 & 60 & 27 & 21 & 8 \\
\hline 29-Aug & $17: 30$ & 30 & 34.5 & 1 & 5 & 30 & 5 & 13 & 10. & 200 & 600 & $27 \bullet$ & 210 & 80 \\
\hline 29-Aug & $18: 00$ & 30 & 35.0 & 1 & 3 & 11 & 7 & 6 & 37 & 12 & 56 & 38 & 27 & 9 \\
\hline 29-Aug & $18: 30$ & 30 & 35.5 & 1 & 1 & 11 & 9 & 6 & 37 & 120 & $56 \bullet$ & 380 & 27 & 9. \\
\hline 29-Aug & $19: 00$ & 30 & 36.0 & & & 5 & & 01 & 31 & 10 & 57 & 39 & 33 & 6 \\
\hline 29-Aug & 19:30 & 30 & 36.5 & & & 5 & & or & 31. & 100 & 57. & 390 & 330 & 6 \\
\hline 29-Aug & $20: 00$ & 30 & 37.0 & & & 4 & & 01 & 22 & 4 & 34 & 32 & 30 & 7 \\
\hline 29-Aug & $20: 30$ & 30 & 37.5 & & & 4 & & 01 & $22 \theta$ & 40 & 340 & 320 & $30 \theta$ & 70 \\
\hline 29-Aug & 21:00 & 30 & 38.0 & & & 4 & & 01 & 12 & 5 & 18 & 33 & 23 & 6 \\
\hline 29-Aug & $21: 30$ & 30 & 38.5 & & & 4 & & 01 & 120 & 50 & $18 \circ$ & 33 • & 230 & 6. \\
\hline 29-Aug & 22:00 & 30 & 39.0 & & & 3 & & $0 f$ & 6 & 3 & 15 & 25 & 37 & 11 \\
\hline 29-Aug & 22:30 & 30 & 39.5 & & & 3 & & 01 & 60 & 30 & $15 e$ & 25 & 370 & 110 \\
\hline 29-Aug & 23:00 & 30 & 40.0 & & & 4 & & 01 & 6 & 3 & 8 & 32 & 36 & 15 \\
\hline 29-Aug & 23:30 & 30 & 40.5 & & & 4 & & $0 t$ & 60 & 30 & 80 & 320 & 360 & $15 \bullet$ \\
\hline 30-Aug & $0: 00$ & 30 & 41.0 & & & 4 & & 01 & 4 & 4 & 7 & 30 & 35 & 20 \\
\hline 30-Aug & $0: 30$ & 30 & 41.5 & & & 4 & & 01 & 40 & 40 & 7. & $30 \bullet$ & 350 & 200 \\
\hline 30-Aug & $1: 00$ & 30 & 42.0 & & & 3 & & of & 2 & 5 & 4 & 28 & 32 & 20 \\
\hline 30.Aug & $1: 30$ & 30 & 42.5 & & & 3 & & $0 \mathrm{f}$ & 20 & 50 & 40 & 280 & $32 \theta$ & 200 \\
\hline 30-Aug & $2: 00$ & 30 & 43.0 & & & 3 & & 01 & 1 & 9 & 6 & 19 & 31 & 20 \\
\hline 30-Aug & $2: 30$ & 30 & 43.5 & & & 3 & & 01 & $1 \theta$ & 90 & 60 & 190 & 310 & 200 \\
\hline 30-Aug & $3: 00$ & 30 & 44.0 & & & 2 & & 01 & 2 & 9 & 5 & 11 & 18 & 24 \\
\hline 30-Aug & $3: 30$ & 30 & 44.5 & & & 2 & & 01 & 20 & $9 \mathrm{e}$ & 50 & 110 & 180 & $24 \theta$ \\
\hline
\end{tabular}


TABLE C.8 (Cont.)

\begin{tabular}{|c|c|c|c|c|c|c|c|c|c|c|c|c|c|c|}
\hline \multirow[b]{2}{*}{ Date } & \multicolumn{3}{|c|}{ Time Since } & \multicolumn{11}{|c|}{ Turbidity (a) } \\
\hline & Time & $\begin{array}{c}\text { Last Sample } \\
(\min .)\end{array}$ & $\begin{array}{c}\text { Elapsed Time } \\
\text { (hours) }\end{array}$ & \begin{tabular}{|l|} 
Crossing "1 \\
Upstroam
\end{tabular} & $\begin{array}{l}\text { Crossing :1 } \\
600 \mathrm{t} \text { - Left }\end{array}$ & $\begin{array}{l}\text { Crossing "1 } \\
600 \mathrm{~h}-\text { Conter }\end{array}$ & $\begin{array}{l}\text { Crossing " } 1 \\
600 \mathrm{ft} \text { - Right }\end{array}$ & $\begin{array}{l}\text { NET Flow } \\
\text { Weighted } \\
\end{array}$ & $\begin{array}{c}\text { At } \\
\text { Crossing } \\
\end{array}$ & $\begin{array}{c}\text { At } \\
\text { Crossing } 44\end{array}$ & $\begin{array}{c}\text { At } \\
\text { Crossing } 45(b)\end{array}$ & $\begin{array}{c}\text { At } \\
\text { Crossing } *(b)\end{array}$ & $\begin{array}{c}\text { At } \\
\text { Crossing } \# 7\end{array}$ & $\begin{array}{c}\text { At } \\
\text { Crosesing }\end{array}$ \\
\hline 30-Aug & $4: 00$ & 30 & 45.0 & & & 2 & & 01 & 2 & 7 & 7 & 8 & 14 & 22 \\
\hline 30-Aug & 4:30 & 30 & 45.5 & & & 2 & & 01 & $2 \bullet$ & 7. & $7 \bullet$ & $8 \cdot$ & $14 \bullet$ & 22 • \\
\hline 30-Aug & $5: 00$ & 30 & 46.0 & & & 2 & & of & 1 & 6 & 8 & 7 & 10 & 26 \\
\hline 30-Aug & $5: 30$ & 30 & 46.5 & & & 2 & & of & 1. & 6. & 6 & $7 \bullet$ & 100 & $26 \bullet$ \\
\hline 30-Aug & $6: 00$ & 30 & 47.0 & & & 2 & & of & 3 & 7 & 8 & 5 & 7 & 27 \\
\hline 30-Aug & $6: 30$ & 30 & 47.5 & & & 2 & & of & 30 & 70 & 8 & 50 & 70 & $27 \circ$ \\
\hline 30-Aug & $7: 00$ & 30 & 48.0 & & & 2 & & $0 f$ & 3 & 11 & B & 4 & 5 & 31 \\
\hline 30-Aug & $7: 30$ & 30 & 48.5 & & & 2 & & $0 f$ & 30 & 11. & B. & 40 & 5. & 31. \\
\hline 30-Aug & $8: 00$ & 30 & 49.0 & & & 2 & . & 01 & 2 & 12 & 7 & 4 & 4 & 28 \\
\hline 30-Aug & $8: 30$ & 30 & 49.5 & & & 2 & & of & 2 & $12 \circ$ & 70 & 40 & 4. & $280^{\circ}$ \\
\hline 30-Aug & $9: 00$ & 30 & 50.0 & & & 4 & & $0 f$ & 1 & 11 & 6 & 4 & 4 & 22 \\
\hline 30-Aug & $9: 30$ & 30 & 50.5 & & & 4 & & of & 10 & 11. & $6 \bullet$ & 40 & 40 & 22 \\
\hline 30-Aug & $10: 00$ & 30 & 51.0 & & & 8 & & of & 1 & 10 & 8 & 5 & 4 & 18 \\
\hline 30-Aug & $10: 30$ & 30 & 51.5 & & & 8 & & of & 1. & 10. & 8 & $5 \bullet$ & 40 & $18 \circ$ \\
\hline 30-Aug & $11: 00$ & 30 & 52.0 & & & 13 & & of & 1 & 7 & 8 & 5 & 5 & 13 \\
\hline 30-Aug & $11: 30$ & 30 & 52.5 & & & 13 & & 01 & 10 & 7. & 8. & $5 \bullet$ & $5 \cdot$ & $13 \circ$ \\
\hline 30-Aug & $12: 00$ & 30 & 53.0 & & & 1 & & of & 4 & 8 & 7 & 7 & 5 & 11 \\
\hline 30.Aug & $12: 30$ & 30 & 53.5 & & & 10 & & 01 & 40 & 8. & 70 & 70 & 5. & $11 \circ$ \\
\hline 30-Aug & $13: 00$ & 30 & 54.0 & & & 1 & & of & 6 & 6 & 7 & 5 & 4 & 10 \\
\hline 30-Aug & $13: 30$ & 30 & 54.5 & & & 10 & & 01 & 60 & 60 & 70 & $5 \bullet$ & 40 & 100 \\
\hline 30-Aug & $14: 00$ & 30 & 55.0 & & & 12 & & 01 & 1 & 3 & 7 & 7 & 5 & 7 \\
\hline 30-Aug & 14:30 & 30 & 55.5 & & & $12 \theta$ & & of & 1. & 30 & 7. & 70 & 5. & 70 \\
\hline 30-Aug & $15: 00$ & 30 & 56.0 & & & 1 & & 01 & 1 & 3 & 6 & 7 & 5 & 7 \\
\hline 30-Aug & $15: 30$ & 30 & 56.5 & & & 10 & & 01 & 10 & 30 & 60 & $7 \bullet$ & 50 & 70 \\
\hline 30-Aug & $16: 00$ & 30 & 57.0 & & & 1 & & 01 & 2 & 3 & 4 & 9 & 5 & 6 \\
\hline 30-Aug & $16: 30$ & 30 & 57.5 & & & 10 & & 01 & 20 & 30 & 40 & 90 & 50 & 60 \\
\hline 30-Aug & $17: 00$ & 30 & 58.0 & & & 1 & & 01 & 1 & 3 & 3 & 9 & 5 & 5 \\
\hline 30-Aug & $17: 30$ & 30 & 58.5 & & & $1 e$ & & 01 & 10 & 3. & 3 • & 9. & 50 & 5. \\
\hline 30-Aug & 18:00 & 30 & 59.0 & & & $1 \mathrm{~m}$ & & 01 & 4 & 3 & 3 & a & 8 & 4 \\
\hline 30-Aug & $18: 30$ & 30 & 59.5 & & & $1 \theta$ & & 01 & 40 & 30 & 30 & 60 & 60 & 40 \\
\hline 30-Aug & 19:00 & 30 & 60.0 & & & $1 \mathrm{~m}$ & & 01 & 2 & 2 & 3 & 7 & 6 & 5 \\
\hline 30-Aug & 19:30 & 30 & 60.5 & & & 10 & & 01 & 20 & 2 & 30 & $7 \bullet$ & 60 & $5 \circ$ \\
\hline 30-Aug & 20:00 & 30 & 61.0 & & & $1 \mathrm{~m}$ & & 01 & 3 & 2 & 4 & 6 & 6 & 5 \\
\hline 30-Aug & $20: 30$ & 30 & 61.5 & & & 10 & & 01 & 30 & 20 & 40 & 60 & 60 & 50 \\
\hline 30-Aug & 21:00 & 30 & 62.0 & & & $1 \mathrm{~m}$ & & 01 & 3 & 2 & 3 & 5 & 5 & 5 \\
\hline 30-Aug & $21: 30$ & 30 & 62.5 & & & 10 & & 01 & 30 & 20 & 3. & 50 & 50 & 50 \\
\hline 30-Aug & 22:00 & 30 & 63.0 & & & $1 \mathrm{~m}$ & & 01 & 4 & 3 & 4 & 3 & 6 & 6 \\
\hline 30-Aug & 22:30 & 30 & 63.5 & & & 10 & & 01 & 40 & 30 & 40 & $3 \bullet$ & 60 & 6. \\
\hline 30-Aug & 23:00 & 30 & 64.0 & & & $1 \mathrm{~m}$ & & of & 2 & 2 & 4 & 6 & 4 & 5 \\
\hline 30-Aug & 23:30 & 30 & 64.5 & & & 10 & & 01 & 20 & 20 & 40 & 6. & 40 & 5. \\
\hline 31-Aug & $0: 00$ & 30 & 65.0 & & & $1 \mathrm{~m}$ & & 01 & 3 & 2 & 3 & 3 & 5 & 5 \\
\hline 31-Aug & $0: 30$ & 30 & 65.5 & & & 10 & & of & 30 & 20 & 30 & 30 & 50 & $5 \circ$ \\
\hline 31-Aug & $1: 00$ & 30 & 66.0 & & & $1 \mathrm{~m}$ & & 01 & 3 & 2 & 2 & 3 & 3 & 6 \\
\hline 31-Aug & $1: 30$ & 30 & 66.5 & & & 10 & & $0 t$ & 30 & $2 \theta$ & 20 & 30 & 30 & 60 \\
\hline 31-Aug & $2: 00$ & 30 & 67.0 & & & $1 \mathrm{~m}$ & & of & 2 & 2 & 3 & 3 & 3 & 7 \\
\hline
\end{tabular}


TABLE C.8 (Cont.)

\begin{tabular}{|c|c|c|c|c|c|c|c|c|c|c|c|c|c|c|}
\hline \multirow[b]{2}{*}{ Date } & \multicolumn{3}{|c|}{ Time Since } & \multicolumn{11}{|c|}{ Turbidity (a) } \\
\hline & Time & $\begin{array}{c}\text { Last Sample } \\
\text { (min.) }\end{array}$ & $\begin{array}{c}\text { Elapsed Time } \\
\text { (hours) }\end{array}$ & $\begin{array}{l}\text { Crossing \#1 } \\
\text { Upstream }\end{array}$ & $\begin{array}{l}\text { Crossing "1 } \\
600 \mathrm{tt} \text { - Left }\end{array}$ & $\begin{array}{l}\text { Crossing " } \\
600 \mathrm{n} \text { - Conter }\end{array}$ & $\begin{array}{l}\text { Crossing "1 } \\
600 \mathrm{H} \text { - Right }\end{array}$ & $\begin{array}{l}\text { NET Flow } \\
\text { Weighted }\end{array}$ & $\begin{array}{c}\text { At } \\
\text { Crossing } * 2\end{array}$ & $\begin{array}{c}\text { At } \\
\text { Crossing } 44\end{array}$ & $\begin{array}{c}\text { At } \\
\text { Crossing }\end{array}$ & $\begin{array}{c}\text { At } \\
\text { Crossing } \because(b)\end{array}$ & $\begin{array}{c}\text { At } \\
\text { Crossing } \because 7\end{array}$ & $\begin{array}{c}\text { At } \\
\text { Crossing } 18\end{array}$ \\
\hline 31-Aug & $2: 30$ & 30 & 67.5 & & & 1. & & 01 & 20 & 20 & $3 \cdot$ & 3. & 30 & 70 \\
\hline 31-Aug & $3: 00$ & 30 & 68.0 & & & $1 \mathrm{~m}$ & & $0 f$ & 3 & 2 & 4 & 5 & 3 & 5 \\
\hline 31-Aug & $3: 30$ & 30 & 68.5 & & & 10 & & of & 3 . & 20 & 40 & 5. & 30 & 5. \\
\hline 31-Aug & $4: 00$ & 30 & 69.0 & & & $1 \mathrm{~m}$ & & of & 3 & 4 & 2 & 4 & 3 & 5 \\
\hline 31-Aug & $4: 30$ & 30 & 69.5 & & & 10 & & of & $3 \bullet$ & 40 & 20 & 4. & 30 & $5 \circ$ \\
\hline 31-Aug & 5:00 & 30 & 70.0 & & & $1 \mathrm{~m}$ & & 01 & 3 & 2 & 2 & 5 & 3 & 8 \\
\hline 31-Aug & $5: 30$ & 30 & 70.5 & & & 10 & & 01 & 38 & $2 \cdot$ & 2 & 5. & 30 & 8. \\
\hline 31-Aug & $6: 00$ & 30 & 71.0 & & & $1 \mathrm{~m}$ & & 01 & 2 & 2 & 3 & 2 & 2 & 6 \\
\hline 31-Aug & $6: 30$ & 30 & 71.5 & & & 10 & & 01 & 20 & 20 & 30 & 20 & 20 & 60 \\
\hline 31-Aug & $7: 00$ & 30 & 72.0 & & & $1 \mathrm{~m}$ & & 01 & 1 & 2 & 2 & 4 & 2 & 7 \\
\hline 31-Aug & $7: 30$ & 30 & 72.5 & & & 10 & & 01 & 10 & 2 & $2 \bullet$ & 40 & 20 & $7 \bullet$ \\
\hline 31-Aug & 8:00 & 30 & 73.0 & & & $1 \mathrm{~m}$ & & 01 & 2 & 1 & 3 & 3 & 3 & 7 \\
\hline 31-Aug & 8:30 & 30 & 73.5 & & & 10 & & 01 & 2 & 1. & 30 & 3. & 3 & 7. \\
\hline 31-Aug & 9:00 & 30 & 74.0 & & & $1 \mathrm{~m}$ & & 01 & 11 & 2 & 2 & 10 & 2 & 8 \\
\hline 31-Aug & $9: 30$ & 30 & 74.5 & & & $1 \bullet$ & & 01 & 11. & 2 & $2 \cdot$ & $10 \theta$ & 2 & 8. \\
\hline 31-Aug & $10: 00$ & 30 & 75.0 & & & $1 \mathrm{~m}$ & & oi & 6 & 2 & 2 & 14 & 7 & 5 \\
\hline 31-Aug & $10: 30$ & 30 & 75.5 & & & 10 & & of & 60 & 20 & 20 & $14 \theta$ & 7 & 50 \\
\hline 31-Aug & $11: 00$ & 30 & 76.0 & & & $1 \mathrm{~m}$ & & 01 & 4 & 3 & 1 & 9 & 26 & 4 \\
\hline 31-Aug & $11: 30$ & 30 & 76.5 & & & $1 \bullet$ & & $0 \mathrm{f}$ & 40 & 3. & 1. & 90 & 26 & 40 \\
\hline 31-Aug & $12: 00$ & 30 & 77.0 & & & $1 \mathrm{~m}$ & & 01 & 2 & 15 & 2 & 13 & 20 & 3 \\
\hline 31-Aug & $12: 30$ & 30 & 77.5 & & & 10 & & of & 20 & 15 & 20 & 130 & 20 & 30 \\
\hline 31-Aug & $13: 00$ & 30 & 78.0 & & & $1 \mathrm{~m}$ & & 01 & 2 & 13 & 2 & 23 & 14 & 3 \\
\hline 31-Aug & $13: 30$ & 30 & 78.5 & & & 10 & & 01 & 20 & 130 & 20 & 230 & 14 & 30 \\
\hline 31.Aug & $14: 00$ & 30 & 79.0 & & & $1 \mathrm{~m}$ & & of & 2 & 4 & 2 & 9 & 22 & 3 \\
\hline 31-Aug & $14: 30$ & 30 & 78.5 & & & 1. & & of & 20 & 40 & 20 & 90 & 22 & 30 \\
\hline 31-Aug & $15: 00$ & 30 & 80.0 & & & $1 \mathrm{~m}$ & & 01 & 2 & 3 & 2 & 7 & 26 & 4 \\
\hline 31-Aug & $15: 30$ & 30 & 80.5 & & & 10 & & of & 20 & 30 & 20 & 70 & 26 & 40 \\
\hline 31-Aug & $16: 00$ & 30 & 81.0 & & & $1 \mathrm{~m}$ & & of & 2 & 3 & 7 & 5 & 26 & 4 \\
\hline 31-Aug & $16: 30$ & 30 & 81.5 & & & 10 & & of & 20 & $3 \theta$ & 70 & 50 & 26 & 40 \\
\hline
\end{tabular}

(a) $m$ = sample missed/value extrapolatod:

= measuments from previous samples are extrapolated for graphing purposes only

I = after the upstream sampler is removed, the NET flow weighted turbidity is assumed to be zero

(for the purposes of calculating the 10 day running average of NET fiow weighted turbidity only)

(b) NOTE: a pulse from something between 586 was removed for analysis of plume from crossing $\# 1$. Values moved to " $e$ " column.

Total Net Downstream Flow-Wolghted NTU:hours $=2938$ 


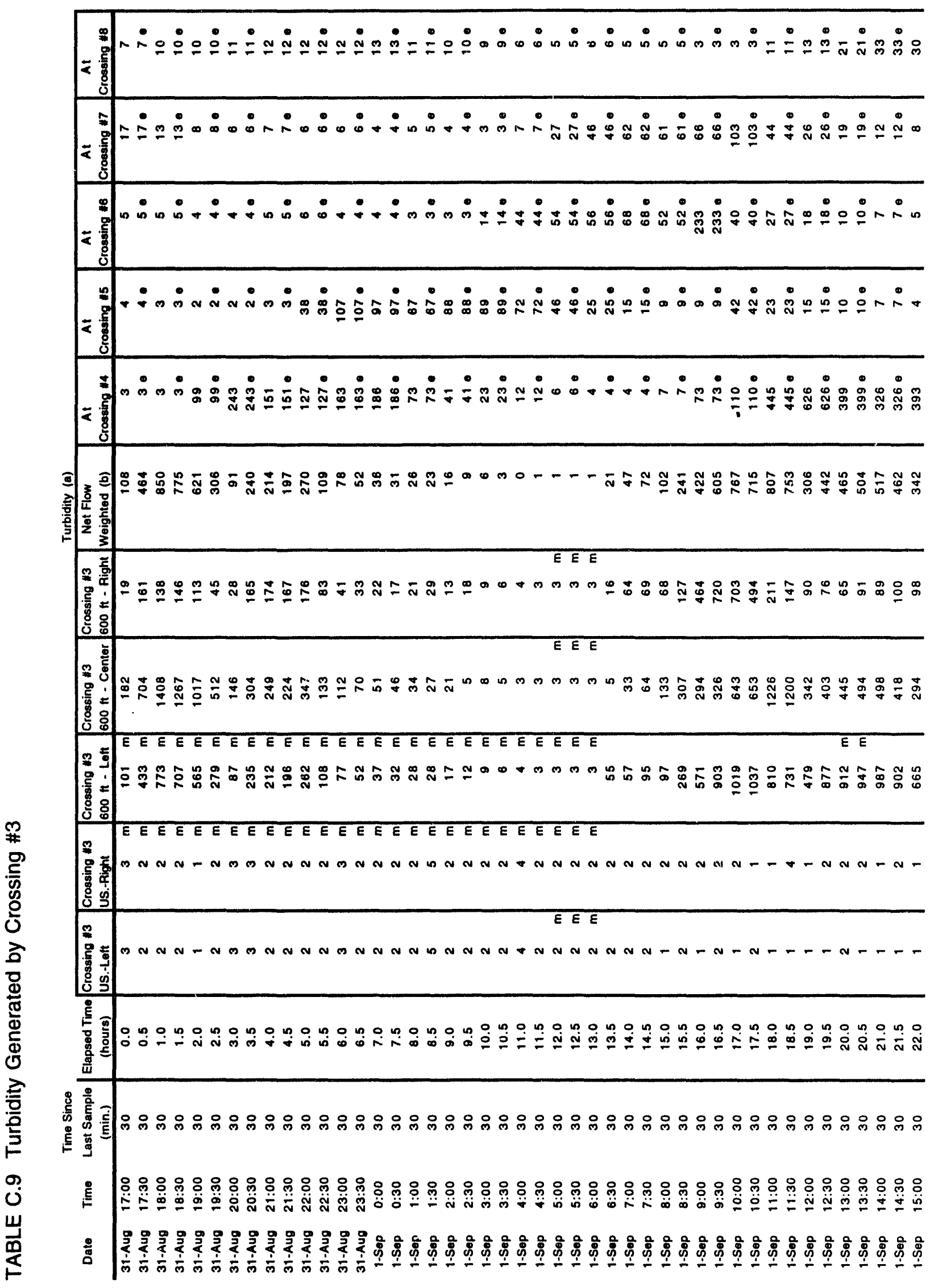


TABLE C.9 (Cont.)

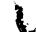

\begin{tabular}{|c|c|c|c|c|c|c|c|c|c|c|c|c|c|c|}
\hline \multirow[b]{2}{*}{ Date } & \multirow{2}{*}{\multicolumn{2}{|c|}{$\begin{array}{c}\text { Time } \\
\text { Time Since } \\
\text { (min.) }\end{array}$}} & \multirow[b]{2}{*}{$\begin{array}{c}\text { Elapsed Time } \\
\text { (hours) }\end{array}$} & \multicolumn{11}{|c|}{ Turbidity (a) } \\
\hline & & & & \begin{tabular}{|l|} 
Crossing *3 \\
US.-Left
\end{tabular} & $\begin{array}{l}\text { Crossing *3 } \\
\text { US.-Right }\end{array}$ & $\begin{array}{l}\text { Crossing } 13 \\
600 \mathrm{H} \text { - Left }\end{array}$ & $\begin{array}{l}\text { Crossing *3 } \\
600 \mathrm{H} \text { - Conter }\end{array}$ & $\begin{array}{l}\text { Crossing } 13 \\
600 \mathrm{ft} \text { - Right }\end{array}$ & $\begin{array}{c}\text { Net Flow } \\
\text { Weighted (b) }\end{array}$ & $\begin{array}{c}\text { At } \\
\text { Crossing } 44\end{array}$ & $\begin{array}{c}\text { At } \\
\text { Crossing }\end{array}$ & $\begin{array}{c}\text { At } \\
\text { Crossing } 46\end{array}$ & $\begin{array}{c}\text { At } \\
\text { Crossing } * 7\end{array}$ & $\begin{array}{c}\text { At } \\
\text { Crossing } * 8\end{array}$ \\
\hline 1-Sep & $\begin{array}{r}15: 30 \\
16: 00\end{array}$ & $\begin{array}{l}30 \\
30\end{array}$ & 22.5 & 1 & 1 & $\begin{array}{r}578 \\
1051\end{array}$ & $\begin{array}{r}380 \\
1148:\end{array}$ & $\begin{array}{r}79 \\
878\end{array}$ & $\begin{array}{r}347 \\
1040\end{array}$ & $\begin{array}{l}3930^{\circ} \\
317\end{array}$ & 40 & $\begin{array}{l}50 \\
6\end{array}$ & $\begin{array}{l}80 \\
6\end{array}$ & $\begin{array}{l}30 . \\
34\end{array}$ \\
\hline $\begin{array}{l}\text { 1-Sep } \\
\text { 1-Sep }\end{array}$ & $\begin{array}{l}16: 00 \\
16: 30\end{array}$ & $\begin{array}{l}30 \\
30\end{array}$ & $\begin{array}{l}23.0 \\
23.5\end{array}$ & $\begin{array}{l}1 \\
1\end{array}$ & $\begin{array}{l}1 \\
1\end{array}$ & $\begin{array}{r}1051 \\
891\end{array}$ & $\begin{array}{c}1148 \\
968\end{array}$ & $\begin{array}{r}878 \\
1086\end{array}$ & $\begin{array}{r}1040 \\
980\end{array}$ & $\begin{array}{l}317 \\
317 \text { 。 }\end{array}$ & 4. & 6 & $\begin{array}{l}6 \\
6 .\end{array}$ & 34. \\
\hline 1-Sep & $17: 00$ & 30 & 24.0 & $i$ & 1 & B6S & .883 & 580 & 646 & 318 & 6 & 16 & 6 & 33 \\
\hline 1-Sep & $17: 30$ & 30 & 24.5 & 1 & 1 & 440 & 363 & 418 & 484 & $318^{\circ}$ & 6. & 16 & 60 & 33. \\
\hline 1-Sop & 18:00 & 30 & 25.0 & 1 & 1 & 390 & 340 & 117 & 288 & 859 & 11 & 34 & 8 & 30 \\
\hline 1. Sep & $18: 30$ & 30 & 25.5 & 1 & 2 & 118 & 91 & 37 & 81 & $859 \circ$ & 110 & 34. & 80 & 30 . \\
\hline 1-Sep & $19: 00$ & 30 & 26.0 & 2 & 1 & 74 & 50 & 26 & 48 & 706 & 30 & 90 & 14 & 23 \\
\hline 1-Sep & $19: 30$ & 30 & 26.5 & 1 & 2 & 163 & 122 & 23 & 103 & 7068 & 30 . & 90. & 140 & 230 \\
\hline 1.Sep & $20: 00$ & 30 & 27.0 & 1 & 1 & 143 & 119 & 26 & 98 & 311 & 289 & 138 & 34 & 16 \\
\hline 1-Sop & $20: 30$ & 30 & 275 & 1 & 1 & 214 & 149 & 23 & 130 & $311^{\circ}$ & $289 \bullet$ & 136 & 340 & 160 \\
\hline 1-Sep & $21: 00$ & 30 & 28.0 & 1 & 1 & 242 & 238 & 33 & 178 & 146 & 246 & 195 & 77 & 13 \\
\hline 1-Sep & 21:30 & 30 & 28.5 & 1 & 1 & 158 & 102 & 27 & 95 & $146 \circ$ & $246 \bullet$ & $195 \circ$ & $77 \circ$ & 130 \\
\hline 1-Sep & 22:00 & 30 & 29.0 & 1 & 1 & 98 & $64: \ldots$ & 26 & 62 & 125 & 253 & 182 & 169 & 10 \\
\hline 1-Sep & 22:30 & 30 & 29.5 & 1 & 1 & 61 & 49 & 25 & 44 & $125 \circ$ & 253 & 182 & $169^{\circ}$ & 100 \\
\hline 1-Sep & 23:00 & 30 & 30.0 & 2 & 2 & 61 & $3 \hat{0}$ & 24 & 39 & 118 & 398 & 173 & 172 & 7 \\
\hline 1-Sep & 23:30 & 30 & 30.5 & 1 & 2 & 54 & 39 & 22 & 37 & 1180 & $398 \bullet$ & 173. & $172 \circ$ & 70 \\
\hline 2-Sep & $0: 00$ & 30 & 31.0 & 2 & 1 & 51 & 35 & 22 & 34 & 70 & 263 & 165 & 151 & 5 \\
\hline 2-Sep & $0: 30$ & 30 & 31.5 & 1 & 2 & 56. & 48 & 20 & 41 & $70 \theta$ & $263 \theta$ & 1658 & 1510 & 50 \\
\hline 2-Sep & $1: 00$ & 30 & 32.0 & 1 & 1 & 38 & 32 & 20 & 29 & 56 & 196 & 171 & 206 & 6 \\
\hline 2-Sep & $1: 30$ & 30 & 32.5 & 1 & 1 & 35 & 28 & 16 & 25 & $560^{\circ}$ & $196 \theta$ & $1711^{\circ}$ & $206 \theta$ & 60 \\
\hline 2-Sep & $2: 00$ & 30 & 33.0 & 2 & 2 & 54 & 24 & 20 & 29 & 48 & 111 & 235 & 197 & 9 \\
\hline 2-Sep & $2: 30$ & 30 & 33.5 & 2 & 1 & 45 & 29 & 20 & 29 & 48. & 1110 & $235 \bullet$ & 1970 & 9. \\
\hline 2-Sep & $3: 00$ & 30 & 34.0 & 2 & 1 & 40 & 21 & 14 & 23 & 33 & 117 & 249 & 261 & 18 \\
\hline 2-Sep & $3: 30$ & 30 & 34.5 & 1 & 2 & 31 & 19 & 16 & 20 & 330 & $117 \circ$ & 249 A & 2618 & $180^{\circ}$ \\
\hline 2-Sep & $4: 00$ & 30 & 35.0 & 2 & 1 & 32 & 20 & 17 & 21 & 26 & 61 & 211 & 298 & 43 \\
\hline 2-Sop & $4: 30$ & 30 & 35.5 & 2 & 2 & 32 & 18 & 14 & 19 & 260 & $811^{\circ}$ & 2110 & $298^{\circ}$ & 430 \\
\hline 2-Sep & 5:00 & 30 & 36.0 & 1 & 1 & 27 & 19 & 12 & 18 & 33 & 49 & 134 & 293 & 63 \\
\hline 2-Sep & $5: 30$ & 30 & 36.5 & 1 & 2 & 27 & 18 & 11 & 17 & $33 \mathrm{e}$ & 490 & $134 \theta$ & $283 \mathrm{e}$ & 630 \\
\hline 2-Sep & $6: 00$ & 30 & 37.0 & 1 & 1 & 23 & 13 & 17 & 16 & 24 & 39 & 94 & 221 & 91 \\
\hline 2-Sep & $6: 30$ & 30 & 37.5 & $1 \mathrm{~m}$ & 1 & $20 \mathrm{~m}$ & 11 & $15 \mathrm{~m}$ & 14 & 240 & 390 & 940 & 2218 & 910 \\
\hline 2-Sep & $7: 00$ & 30 & 38.0 & 1 & 1 & $17 \mathrm{~m}$ & 10 & $13 \mathrm{~m}$ & 12 & 29 & 30 & 79 & 29 & 99 \\
\hline 2-Sep & $7: 30$ & 30 & 38.5 & 1 & $\mathrm{~m}$ & 15 & 9 & 12 & 11 & $29 \theta$ & 300 & 798 & $29 \theta$ & $99 \theta$ \\
\hline 2.Sep & 8:00 & 30 & 39.0 & 1 & 1 & 11 & 8 & 11 & 9 & 19 & 28 & 29 & 90 & 100 \\
\hline 2.Sep & $8: 30$ & 30 & 39.5 & 1 & $\mathrm{~m}$ & 11 & 7 & 12 & 9 & $19 \theta$ & 280 & 290 & 900 & $100 \theta$ \\
\hline 2-Sep & 9:00 & 30 & 40.0 & 1 & $\mathrm{~m}$ & 17 & 23 & 10 & 16 & $14 \mathrm{~m}$ & 25 & 42 & 65 & 110 \\
\hline 2-Sep & $9: 30$ & 30 & 40.5 & 2 & 1 & 51 & 49 & 15 & 38 & $14 e$ & $25 \mathrm{e}$ & 420 & 650 & 1100 \\
\hline 2.Sep & $10: 00$ & 30 & 41.0 & 1 & $m$ & 80 & 62 & 23 & 55 & 9 & 21 & 34 & 50 & 184 \\
\hline 2-Sep & $10: 30$ & 30 & 41.5 & 1 & $\mathrm{~m}$ & 81 & 67 & 28 & 59 & $9 \mathrm{e}$ & 210 & 340 & 500 & 1840 \\
\hline 2-Sep & $11: 00$ & 30 & 42.0 & 1 & $\mathrm{~m}$ & 71 & 79 & 30 & 61 & 16 & 22 & 28 & 47 & 177 \\
\hline 2-Sep & $11: 30$ & 30 & 42.5 & 2 & $\mathrm{~m}$ & 73 & 58 & 35 & 54 & $16 \theta$ & $22 \theta$ & $28 \theta$ & $47 \circ$ & 1770 \\
\hline 2-Sep & $12: 00$ & 30 & 43.0 & 2 & $\mathrm{~m}$ & 74 & 83 & 37 & 65 & 45 & 21 & 22 & 59 & 211 \\
\hline 2-Sep & $12: 30$ & 30 & 43.5 & 1 & $\mathrm{~m}$ & 84 & 52 & 38 & 56 & $45 \theta$ & 210 & $22 \theta$ & 590 & 2110 \\
\hline 2-Sep & $13: 00$ & 30 & 44.0 & 1 & $\mathrm{~m}$ & 62 & 50 & 31 & 47 & 58 & 12 & 19 & 27 & 188 \\
\hline 2-Sep & $13: 30$ & 30 & 44.5 & 1 & $\mathrm{~m}$ & 63 & 48 & 34 & 47 & $58 \mathrm{\theta}$ & $12 \theta$ & 190 & $27 \theta$ & 1880 \\
\hline
\end{tabular}


TABLE C.9 (Cont.)

\begin{tabular}{|c|c|c|c|c|c|c|c|c|c|c|c|c|c|c|}
\hline \multirow[b]{2}{*}{ Date } & \multicolumn{3}{|c|}{ Time Since } & \multicolumn{11}{|c|}{ Turbidity (a) } \\
\hline & Time & $\begin{array}{c}\text { Lest Samplo } \\
\text { (min.) }\end{array}$ & $\begin{array}{c}\text { Elapsod Timo } \\
\text { (hours) }\end{array}$ & $\begin{array}{l}\text { Crossing } 13 \\
\text { US.-Left }\end{array}$ & $\begin{array}{l}\text { Crossing \#3 } \\
\text { US.-Aight }\end{array}$ & $\begin{array}{l}\text { Crossing } * 3 \\
600 \mathrm{ft} \text { - Left }\end{array}$ & $\begin{array}{l}\text { Crossing } * 3 \\
600 \mathrm{ft} \text { - Center }\end{array}$ & $\begin{array}{l}\text { Crossing } \# 3 \\
600 \mathrm{ft} \text { - Right }\end{array}$ & $\begin{array}{c}\text { Net Flow } \\
\text { Weighted (b) } \\
\end{array}$ & $\begin{array}{c}\text { At } \\
\text { Crossing } 44\end{array}$ & $\begin{array}{c}\text { At } \\
\text { Crossing } 15\end{array}$ & $\begin{array}{c}\text { At } \\
\text { Crossing } 16\end{array}$ & $\begin{array}{c}\text { At } \\
\text { Crossing } \# 7\end{array}$ & $\begin{array}{c}\text { At } \\
\text { Crossing } 8\end{array}$ \\
\hline 2-Sep & $14: 00$ & 30 & 45.0 & 2 & $1 \mathrm{~m}$ & 56 & 48 & 33 & 44 & 52 & 14 & 17 & 22 & 121 \\
\hline 2-Sop & $14: 30$ & 30 & 45.5 & 2 & 1 & 40 & 40 & 32 & 36 & $52 \circ$ & $14 \bullet$ & $17 \bullet$ & 22 & $121 \circ$ \\
\hline 2-Sep & 15:00 & 30 & 46.0 & 2 & 1 & 178 & 254 & 186 & 211 & 48 & 27 & 16 & 28 & 89 \\
\hline 2-Sep & $15: 30$ & 30 & 46.5 & 1 & $1 \mathrm{~m}$ & 85 & 228 & 117 & 156 & 48. & $27 \bullet$ & $18 \cdot$ & 28. & 89. \\
\hline 2-Sop & $16: 00$ & 30 & 47.0 & 2 & 1 & 67 & 155 & 118 & 117 & 45 & 27 & 14 & 18 & 67 \\
\hline 2-Sep & $16: 30$ & 30 & 47.5 & 1 & 1 & 45 & 99 & 99 & 82 & $45 \bullet$ & $27 \bullet$ & $14 \bullet$ & 180 & $67 \circ$ \\
\hline 2-Sep & 17:00 & 30 & 48.0 & 1 & $1 \mathrm{~m}$ & 78 & 65 & 74 & 70 & 296 & 34 & 11 & 17 & 49 \\
\hline 2-Sep & $17: 30$ & 30 & 48.5 & 1 & 1 & 17 & 28 & 57 & 32 & $296 \bullet$ & 34. & 11. & $17 \bullet$ & 49. \\
\hline 2-Sep & 18:00 & 30 & 49.0 & 1 & 1 & 12 & 28 & 45 & 27 & 206 & 46 & 11 & 13 & 42 \\
\hline 2-Sop & $18: 30$ & 30 & 49.5 & 2 & 1 & 11 & 22 & 26 & 19 & 206 & 46 & $11 \bullet$ & 130 & 42. \\
\hline 2-Sep & 19:00 & 30 & 50.0 & 1 & 2 & 9 & 352 & 38 & 160 & 415 & 36 & 12 & 14 & 33 \\
\hline 2-Sep & $19: 30$ & 30 & 50.5 & 2 & 1 & 9 & 76 & 35 & 43 & $415 \bullet$ & 36. & $12 \bullet$ & 140 & 33 . \\
\hline 2-Sep & $20: 00$ & 30 & 51.0 & 2 & 1 & 8 & 28 & 25 & 19 & 50 & 56 & 15 & 15 & 27 \\
\hline 2-Sep & $20: 30$ & 30 & 51.5 & 1 & 1 & 7 & 112 & $\boldsymbol{i} \hat{\mathbf{s}}$ & 54 & 500 & 56. & 15. & 150 & $27 \bullet$ \\
\hline 2-Sep & 21:00 & 30 & 52.0 & 2 & 3 & 7 & 53 & 21 & 28 & 31 & 110 & 19 & 15 & 26 \\
\hline 2-Sop & 21:30 & 30 & 52.5 & 1 & 2 & 7 & 56 & 22 & 30 & 31. & 110 & $19 \bullet$ & $15 e$ & $26 \bullet$ \\
\hline 2-Sop & 22:00 & 30 & 53.0 & 1 & 1 & 4 & 104 & 16 & 48 & 24 & 108 & 22 & 20 & 18 \\
\hline 2-Sep & $22: 30$ & 30 & 53.5 & 1 & 2 & 6 & 15 & 18 & 12 & 24. & 1080 & $22 \bullet$ & 200 & 180 \\
\hline 2-Sop & 23:00 & 30 & 54.0 & 1 & 2 & 5 & 26 & 14 & 15 & 16 & 77 & 26 & 25 & 31 \\
\hline 2-Sop & 23:30 & 30 & 54.5 & 1 & 2 & 5 & 7 & 12 & 6 & $16 \bullet$ & $.7 \bullet$ & $26 \bullet$ & $25 e$ & 310 \\
\hline 3-Sep & $0: 00$ & 30 & 55.0 & 1 & 2 & 4 & 34 & 12 & 17 & 15 & 51 & 30 & 33 & 14 \\
\hline 3-Sep & $0: 30$ & 30 & 55.5 & 1 & 2 & 5 & 7 & 10 & 6 & $15 \theta$ & 510 & 30. & 33 - & $14 \theta$ \\
\hline 3-Sop & $1: 00$ & 30 & 56.0 & 2 & 2 & 4 & 110 & 8 & 48 & 14 & 38 & 50 & 38 & 16 \\
\hline 3-Sep & $1: 30$ & 30 & 56.5 & 2 & 2 & 5 & 100 & 7 & 43 & $14 \theta$ & 38 & 50. & 380 & $16 \theta$ \\
\hline 3-Sop & 2:00 & 30 & 57.0 & 1 & 2 & 4 & 39 & 9 & 19 & 7 & 25 & 49 & 40 & 14 \\
\hline 3-Sop & 2:30 & 30 & 57.5 & 2 & 2 & 4 & 39 & 8 & 18 & $70^{\circ}$ & 250 & $49 \bullet$ & 40 & 140 \\
\hline 3-Sop & 3:00 & 30 & 58.0 & 2 & 2 & 4 & 11 & 7 & 6 & 12 & 18 & 44 & 55 & 11 \\
\hline 3-Sop & 3:30 & 30 & 58.5 & 2 & 2 & 4 & 21 & 9 & 11 & $12 \bullet$ & $18 \bullet$ & $44^{\circ}$ & $55^{\circ}$ & 110 \\
\hline 3-Sep & $4: 00$ & 30 & 59.0 & 1 & 2 & 3 & 25 & 7 & 12 & 12 & 17 & 37 & 60 & 15 \\
\hline 3-Sop & $4: 30$ & 30 & 59.5 & 2 & 2 & 4 & 26 & 6 & 12 & 120 & $17 \bullet$ & $37 \bullet$ & 600 & 150 \\
\hline 3-Sep & $5: 00$ & 30 & 60.0 & 2 & 2 & 4 & 47 & 7 & 21 & 11 & 18 & 29 & 78 & 17 \\
\hline 3-Sep & $5: 30$ & 30 & 60.5 & 4 & 3 & 5 & 24 & 7 & 10 & $11 \circ$ & $18 \circ$ & 290 & 780 & $17 \circ$ \\
\hline 3-Sep & $6: 00$ & 30 & 61.0 & 5 & 5 & 5 & 77 & 7 & 31 & 4 & 16 & 19 & 41 & 38 \\
\hline 3-Sep & $6: 30$ & 30 & 61.5 & 6 & 6 & $6 \mathrm{~m}$ & 76 & 7 & 30 & 40 & 160 & 190 & 410 & $38 \circ$ \\
\hline 3-Sep & 7:00 & 30 & 62.0 & 7 & 6 & $7 \mathrm{~m}$ & 35 & $8 \mathrm{~m}$ & i3 & 6 & 12 & 15 & 28 & 23 \\
\hline 3-Sop & $7: 30$ & 30 & 62.5 & 7 & 7 & 8 & 8 & $10 \mathrm{~m}$ & 2 & 60 & 120 & $15 \circ$ & 280 & 230 \\
\hline 3-Sep & $8: 00$ & 30 & 63.0 & 7 & 5 & 9 & 9 & 11 & 4 & 5 & 7 & 12 & 19 & 25 \\
\hline 3-Sep & $8: 30$ & 30 & 63.5 & 6 & 5 & 8 & 10 & 20 & 7 & 50 & 7 & 120 & $19 e$ & 250 \\
\hline 3-Sep & $9: 00$ & 30 & 64.0 & 4 & 7 & 13 & 37 & 78 & 37 & 7 & 6 & 13 & 18 & 24 \\
\hline 3-Sep & $9: 30$ & 30 & 64.5 & 4 & 6 & 25 & 49 & 81 & 47 & 70 & 60 & 130 & 180 & $24^{\circ}$ \\
\hline 3-Sep & $10: 00$ & 30 & 65.0 & 4 & 6 & 25 & 37 & 62 & 36 & 8 & 7 & 10 & 14 & 27 \\
\hline 3-Sep & $10: 30$ & 30 & 65.5 & 3 & 3 & 18 & 29 & 38 & 25 & 80 & $7 e$ & 100 & $14 \theta$ & $27 \theta$ \\
\hline 3-Sep & $11: 00$ & 30 & 66.0 & 3 & 5 & 15 & 32 & 63 & 32 & 36 & 5 & 15 & 12 & 30 \\
\hline 3.Sep & $11: 30$ & 30 & 66.5 & 2 & 3 & 10 & 36 & 59 & 35 & 360 & 50 & 150 & $12 \theta$ & 300 \\
\hline 3-Sep & $12: 00$ & 30 & 67.0 & 2 & 3 & 20 & 51 & 60 & 42 & 42 & 6 & 7 & 9 & 27 \\
\hline
\end{tabular}


TABLE C.9 (Cont.)

\begin{tabular}{|c|c|c|c|c|c|c|c|c|c|c|c|c|c|c|c|c|}
\hline \multirow[b]{2}{*}{ Date } & \multicolumn{3}{|c|}{ Time Since } & \multicolumn{13}{|c|}{ Turbidity (a) } \\
\hline & Time & $\begin{array}{c}\text { Last Sample } \\
\text { (min.) }\end{array}$ & $\begin{array}{c}\text { Elapsed Time } \\
\text { (hours) }\end{array}$ & $\begin{array}{l}\text { Crossing *3 } \\
\text { uS.-Lett }\end{array}$ & & $\begin{array}{l}\text { Crossing *3 } \\
\text { Us.-Aight }\end{array}$ & $\begin{array}{l}\text { Crossing *3 } \\
600 \mathrm{th} \text { - Left }\end{array}$ & & $\begin{array}{l}\text { Crossing } \# 3 \\
600 \mathrm{H} \text { - Center }\end{array}$ & $\begin{array}{l}\text { Crossing *3 } \\
600 \mathrm{tt} \text { - Right }\end{array}$ & $\begin{array}{c}\text { Net Flow } \\
\text { Weighted (b) }\end{array}$ & $\begin{array}{c}\text { At } \\
\text { Crossing :4 }\end{array}$ & $\begin{array}{c}\text { At } \\
\text { Crossing us }\end{array}$ & $\begin{array}{c}\text { At } \\
\text { Crossing } 6\end{array}$ & $\begin{array}{c}\text { At } \\
\text { Crossing } ₫ 7\end{array}$ & $\begin{array}{c}\text { At } \\
\text { Crossing *8 }\end{array}$ \\
\hline 3-Sep & $12: 30$ & 30 & 67.5 & 2 & & 2 & 23 & & 46 & 40 & 36 & $42 \theta$ & 60 & $7 \cdot$ & $9 \cdot$ & 270 \\
\hline 3-Sep & $13: 00$ & 30 & 68.0 & 1 & & 2 & 28 & & 65 & 39 & 45 & 43 & 7 & 10 & 9 & 22 \\
\hline 3-Sep & 13:30 & 30 & 68.5 & 1 & & 2 & 31 & & 42 & 26 & 33 & 430 & $7 \bullet$ & 10. & 90 & $22 \circ$ \\
\hline 3-Sop & $14: 00$ & 30 & 69.0 & 1 & & 2 & 25 & & 35 & 11 & 24 & 45 & 20 & 8 & 7 & 26 \\
\hline 3-Sep & $14: 30$ & 30 & 69.5 & 1 & & 3 & 48 & & 77 & 16 & 49 & 450 & 20 & 8. & 7. & 260 \\
\hline 3-Sep & $15: 00$ & 30 & 70.0 & 1 & & 4 & 66 & & 149 & 11 & 82 & 33 & 25 & 8 & 7 & 20 \\
\hline 3-Sop & $15: 30$ & 30 & 70.5 & 2 & & 1 & 59 & & 107 & 67 & 80 & 33. & 25. & 80 & 70 & 20 \\
\hline 3-Sep & $16: 00$ & 30 & 71.0 & 1 & & 4 & 56 & & 265 & 370 & 233 & 31 & 28 & 15 & 6 & 18 \\
\hline 3-Sep & $16: 30$ & 30 & 71.5 & 1 & & 2 & 102 & & 292 & 361 & 256 & 31. & 280 & 15 & 60 & 180 \\
\hline 3-Sep & $17: 00$ & 30 & 72.0 & 1 & & 4 & 139 & & 389 & 347 & 302 & 50 & 30 & 7 & 7 & 10 \\
\hline 3-Sep & $17: 30$ & 30 & 72.5 & 1 & & 1 & 193 & & 275 & 62 & 188 & 50. & 30 e & $7 \bullet$ & $7 \bullet$ & 100 \\
\hline 3-Sop & $18: 00$ & 30 & 73.0 & 1 & & 1 & 187 & & 170 & 42 & 136 & 292 & 32 & 8 & 7 & 16 \\
\hline 3-Sep & $18: 30$ & 30 & 73.5 & 1 & & 1 & 149 & & 141 & 29 & 109 & $292 \theta$ & 32. & 8. & 7. & 160 \\
\hline 3-Sep & $19: 00$ & 30 & 74.0 & 2 & & 3 & $0 n$ & $\mathrm{~m}$ & 81 & 21 & 79 & 223 & 30 & 11 & 7 & 12 \\
\hline 3-Sop & $19: 30$ & 30 & 74.5 & 2 & . & 3 & $0 \pi$ & $\mathrm{m}$ & 81 & $0 \mathrm{~m}$ & 79 & 223 & 30. & 110 & 7. & 120 \\
\hline 3-Sep & $20: 00$ & 30 & 75.0 & 3 & & 3 & $0 \quad n$ & $\mathrm{~m}$ & 28 & $0 \mathrm{~m}$ & 25 & 110 & 23 & 15 & 11 & 9 \\
\hline 3-Sep & $20: 30$ & 30 & 75.5 & 3 & . & 3 & $0 \pi$ & $\mathrm{m}$ & 28 & $0 \mathrm{~m}$ & 25 & 1100 & 230 & 150 & 110 & 90 \\
\hline 3-Sep & 21:00 & 30 & 76.0 & 2 & & 3 & $0 \pi$ & $\mathrm{m}$ & 21 & $0 \mathrm{~m}$ & 19 & 48 & 51 & 19 & 14 & 4 \\
\hline 3-Sep & $21: 30$ & 30 & 76.5 & 2 & . & 3 & $0 \pi$ & $\mathrm{m}$ & 21 & $0 \mathrm{~m}$ & 19 & 480 & 510 & 190 & 140 & 4. \\
\hline 3-Sep & $22: 00$ & 30 & 77.0 & 3 & & 3 & $0 \pi$ & $\mathrm{m}$ & 17 & $0 \mathrm{~m}$ & 14 & 32 & 160 & 19 & 18 & 5 \\
\hline 3-Sep & $22: 30$ & 30 & 77.5 & 3 & e) & 3 & $0 \pi$ & $\mathrm{m}$ & 17 & $0 \mathrm{~m}$ & 14 & 320 & $160 \theta$ & 19. & 180 & $5 \mathrm{\theta}$ \\
\hline 3-Sep & 23:00 & 30 & 78.0 & 4 & & 4 & $0 \quad n$ & $\mathrm{~m}$ & 13 & $0 \mathrm{~m}$ & 9 & 23 & 174 & 23 & 22 & 6 \\
\hline 3-Sop & $23: 30$ & 30 & 78.5 & 4 & e & 4 & $0 \pi$ & $\mathrm{m}$ & 13 & $0 \mathrm{~m}$ & 9 & 230 & $174 \circ$ & 23. & 22 & 60 \\
\hline 4-Sep & $0: 00$ & 30 & 79.0 & 7 & & 7 & $0 \pi$ & m) & 12 & $0 \mathrm{~m}$ & 5 & 22 & 132 & 19 & 22 & 5 \\
\hline 4-Sep & $0: 30$ & 30 & 79.5 & 7 & . & 7 & $0 \pi$ & $\mathrm{m}$ & 12 & $0 \mathrm{~m}$ & 5 & 220 & 132 & 190 & 22 & 50 \\
\hline 4-Sop & $1: 00$ & 30 & 80.0 & 10 & & 11 & $0 \mathrm{n}$ & $\mathrm{m}$ & 18 & $0 \mathrm{~m}$ & 8 & 20 & 55 & 24 & 21 & 6 \\
\hline 4-Sep & $1: 30$ & 30 & 80.5 & 10 & . & 11 & $0 \mathrm{n}$ & $\mathrm{m}$ & 18 & $0 \mathrm{~m}$ & 8 & 200 & 55 & $24 \circ$ & 210 & 60 \\
\hline 4-Sop & 2:00 & 30 & 81.0 & 14 & & 16 & $0 \mathrm{n}$ & $\mathrm{m}$ & 15 & $0 \mathrm{~m}$ & 0 & 18 & 36 & 55 & 22 & 9 \\
\hline 4-Sop & $2: 30$ & 30 & 81.5 & 14 & e) & 16 & $0 \pi$ & $\mathrm{m}$ & 15 & $0 \mathrm{~m}$ & 0 & 180 & 360 & $55^{\circ}$ & 22 & 90 \\
\hline 4-Sef & $3: 00$ & 30 & 82.0 & 21 & & 21 & $0 \pi$ & $\mathrm{m}$ & 20 & $0 \mathrm{~m}$ & 0 & 19 & 26 & 56 & 34 & 6 \\
\hline 4-Sep & $3: 30$ & 30 & 82.5 & 21 & . & 21 & $0 \mathrm{~m}$ & $\mathrm{~m}$ & 20 & $0 \mathrm{~m}$ & 0 & $19 \theta$ & $26 \theta$ & $56 \circ$ & $34 e$ & 60 \\
\hline 4-Sep & 4:00 & 30 & 83.0 & 13 & & 23 & $0 \pi$ & $\mathrm{m}$ & 23 & $0 \mathrm{~m}$ & 5 & 19 & 19 & 62 & 55 & 9 \\
\hline 4-SeD & $4: 30$ & 30 & 83.5 & 13 & . & 23 & $0 \mathrm{~m}$ & $\mathrm{~m}$ & 23 & $0 \mathrm{~m}$ & 5 & 19. & 190 & 62 & 550 & 90 \\
\hline 4-0ep & $5: 00$ & $3 c$ & 84.0 & 14 & & 19 & $0 \pi$ & $m$ & 22 & $0 \mathrm{~m}$ & 6 & 24 & 15 & 24 & 71 & 12 \\
\hline 4-Sep & $5: 30$ & 30 & 84.5 & 14 & - & 19 & $0 \pi$ & $\mathrm{m}$ & 22 & $0 \mathrm{~m}$ & 6 & $24 \theta$ & 150 & $24 \circ$ & 710 & $12 \theta$ \\
\hline 4-Sep & $6: 00$ & 30 & 85.0 & 10 & & 12 & $0 \pi$ & $\mathrm{m}$ & 13 & $0 \mathrm{~m}$ & 2 & 22 & 15 & 30 & 56 & 13 \\
\hline 4-Sep & $6: 30$ & 30 & 85.5 & 10 & e) & 12 & $0 \mathrm{~m}$ & $\mathrm{~m}$ & 13 & $0 \mathrm{~m}$ & 2 & 220 & 150 & 300 & 560 & 130 \\
\hline 4-Sep & $7: 00$ & 30 & 86.0 & 5 & & 8 & $0 \quad n$ & $\mathrm{~m}$ & 10 & $0 \mathrm{~m}$ & 4 & 21 & 14 & 22 & 39 & 18 \\
\hline 4-Sep & $7: 30$ & 30 & 86.5 & 5 & e & 8 & $0 \quad \pi$ & $\mathrm{m}$ & 10 & $0 \mathrm{~m}$ & 4 & 210 & 140 & 22 & 390 & 180 \\
\hline 4-Sep & $8: 00$ & 30 & 87.0 & 4 & & 8 & $0 \quad m$ & $\mathrm{~m}$ & 7 & $0 \mathrm{~m}$ & 1 & 14 & 13 & 17 & 29 & 11 \\
\hline 4-Sep & $8: 30$ & 30 & 87.5 & 4 & $\theta$ & 8 & $0 \mathrm{~m}$ & $\mathrm{~m}$ & 7 & $0 \quad m$ & 1 & $14 \theta$ & 130 & 170 & 290 & 110 \\
\hline 4-Sep & $9: 00$ & 30 & 88.0 & 3 & & 5 & $0 \quad m$ & $\mathrm{~m}$ & 5 & $0 \mathrm{~m}$ & 1 & 9 & 19 & $14 \mathrm{~m}$ & 20 & 11 \\
\hline 4-Sep & $9: 30$ & 30 & 88.5 & 3 & $\theta$ & 5 & $0 \mathrm{~m}$ & $\mathrm{~m}$ & 5 & $0 \mathrm{~m}$ & 1 & 90 & 190 & $14 \theta$ & $20 \mathrm{e}$ & 110 \\
\hline 4-Sep & $10: 00$ & 30 & 89.0 & 2 & & 5 & $0 \mathrm{~m}$ & $\mathrm{~m}$ & 12 & $0 \mathrm{~m}$ & 9 & 16 & 10 & 10 & 14 & 31 \\
\hline 4-Sep & $10: 30$ & 30 & 89.5 & 2 & ol & 5 & $0 \mathrm{~m}$ & $\mathrm{~m}$ & 12 & $0 \mathrm{~m}$ & 9 & 160 & $19 \mathrm{e}$ & $10 \mathrm{\theta}$ & 140 & 310 \\
\hline
\end{tabular}


TABLE C.9 (Cont.)

\begin{tabular}{|c|c|c|c|c|c|c|c|c|c|c|c|c|c|c|c|}
\hline \multirow[b]{2}{*}{ Date } & \multicolumn{3}{|c|}{ Time Since } & \multicolumn{12}{|c|}{ Turbidity (a) } \\
\hline & Time & $\begin{array}{c}\text { Last Sample } \\
\text { (min.) }\end{array}$ & \begin{tabular}{|c|}
$\begin{array}{c}\text { Elapsed Timo } \\
\text { (hours) }\end{array}$ \\
\end{tabular} & $\begin{array}{l}\text { Crossing } \# 3 \\
\text { US. Loft }\end{array}$ & & $\begin{array}{l}\text { Crossing *3 } \\
\text { US.-Pight }\end{array}$ & $\begin{array}{l}\text { Crossing } 13 \\
600 \mathrm{n} \text { - Left }\end{array}$ & $\begin{array}{l}\text { Crossing } * 3 \\
600 \mathrm{H} \text { - Center }\end{array}$ & $\begin{array}{l}\text { Crossing } 13 \\
600 \mathrm{tt} \text { - Right }\end{array}$ & \begin{tabular}{|c} 
Net Flow \\
Weighted (b;
\end{tabular} & $\begin{array}{c}\text { At } \\
\text { Crossing } 44\end{array}$ & $\begin{array}{c}\text { At } \\
\text { Crossing } 15\end{array}$ & $\begin{array}{c}\text { Al } \\
\text { Crossing } 6\end{array}$ & $\begin{array}{c}\text { At } \\
\text { Crossing }\end{array}$ & $\begin{array}{c}\text { At } \\
\text { Crossing } * 8\end{array}$ \\
\hline 4-Sep & $11: 00$ & 30 & 90.0 & 2 & & 3 & $0 \mathrm{~m}$ & 12 & $0 \mathrm{~m}$ & 10 & 10 & 19 & 15 & 11 & 28 \\
\hline 4-Sop & $11: 30$ & 30 & 90.5 & 2 & - & 3 & $0 \mathrm{~m}$ & 12 & $0 \mathrm{~m}$ & 10 & 10. & 19. & 150 & 110 & 28 . \\
\hline 4-Sop & $12: 00$ & 30 & 91.0 & 2 & & 3 & $0 \mathrm{~m}$ & 10 & $0 \mathrm{~m}$ & 8 & 13 & 13 & 11 & 10 & 31 \\
\hline 4-Sop & $12: 30$ & 30 & 91.5 & 2 & . & 3 & $0 \mathrm{~m}$ & 10 & $0 \mathrm{~m}$ & 8 & $.13 \bullet$ & $13 \bullet$ & 110 & 10 & 31. \\
\hline 4-Sop & 13:00 & 30 & 92.0 & 2 & & 3 & $0 \mathrm{~m}$ & 39 & $0 \mathrm{~m}$ & 37 & 12 & 13 & 10 & 10 & 30 \\
\hline 4-Sop & $13: 30$ & 30 & 92.5 & 2 & . & 3 & $0 \mathrm{~m}$ & 39 & $0 \mathrm{~m}$ & 37 & 12 & 130 & $10 \bullet$ & 100 & 30 . \\
\hline 4-Sop & $14: 00$ & 30 & 93.0 & 3 & & 4 & $0 \mathrm{~m}$ & 21 & $0 \mathrm{~m}$ & 18 & 12 & 10 & 19 & 11 & 35 \\
\hline 4-Sop & $14: 30$ & 30 & 93.5 & 3 & - & 4 & $0 \mathrm{~m}$ & 21 & $0 \mathrm{~m}$ & 18 & $12 \theta$ & $10 \bullet$ & $19 \bullet$ & 110 & $35 \bullet$ \\
\hline 4-Sop & $15: 00$ & 30 & 94.0 & 3 & & 3 & 514 & 1392 & 611 & 907 & 21 & 9 & 17 & 13 & 27 \\
\hline 4-Sop & $15: 30$ & 30 & 94.5 & 3 & . & 3 & 514 . & 1043 & 384 & 694 & 21. & 9. & 17. & 13. & 270 \\
\hline 4-Sep & $16: 00$ & 30 & 95.0 & 2 & & 3 & 536 & 642 & 347 & 522 & 286 & 11 & 15 & 13 & 23 \\
\hline 4-Sop & $16: 30$ & 30 & 95.5 & 2 & . & 3 & 536. & 359 & 250 & 375 & $286 \bullet$ & 110 & $15 \circ$ & 130 & $23 \circ$ \\
\hline 4-Sop & $17: 00$ & 30 & 96.0 & 2 & & 4 & 319 & 210 & 94 & 204 & 785 & 8 & 9 & 14 & 20 \\
\hline 4-Sop & $17: 30$ & 30 & 96.5 & 2 & . & 4 & $319 \cdot$ & 118 & 80 & 162 & $785 \circ$ & 8. & 9 . & $14 \circ$ & 20. \\
\hline 4-Sop & 18:00 & 30 & 97.0 & 4 & & 4 & 140 & 54 & 67 & 79 & 479 & 13 & 10 & 10 & 18 \\
\hline 4-Sop & $18: 30$ & 30 & 97.5 & 4 & . & 4 & 140 & 42 & 59 & 71 & 479. & $13 \cdot$ & $10 \bullet$ & 100 & $18 \circ$ \\
\hline 4-Sop & 19:00 & 30 & 98.0 & 4 & $\mathrm{~m}$ & 4 & 40 & 26 & 44 & 31 & 150 & 28 & 9 & 12 & 14 \\
\hline 4-Sep & 19:30 & 30 & 98.5 & 4 & $\mathrm{~m}$ & 4 & 25 & 15 & 49 & 24 & $150 \bullet$ & 280 & 9. & 12 & 140 \\
\hline 4-Sop & $20: 00$ & 30 & 99.0 & 41 & $\mathrm{~m}$ & 4 & 14 & 9 & 38 & 15 & 70 & 222 & 6 & 11 & 11 \\
\hline 4-Sep & 20:30 & 30 & 99.5 & 4 & $m$ & 4 & 14 & 9 & 34 & 14 & 70. & 2220 & 60 & 110 & 110 \\
\hline 4-Sop & 21:00 & 30 & 100.0 & 4 & $\mathrm{~m}$ & 4 & 12 & 7 & 31 & 11 & 34 & 422 & 9 & 7 & 12 \\
\hline 4-Sep & $21: 30$ & 30 & 100.5 & 4 & $\mathrm{~m}$ & 4 & 14 & 8 & 27 & 11 & $34^{\circ}$ & $422 \circ$ & 90 & 70 & 120 \\
\hline 4-Sep & 22:00 & 30 & 101.0 & 3 & $\mathrm{~m}$ & 4 & 10 & 6 & 27 & 10 & 21 & 530 & 11 & 9 & 11 \\
\hline 4-Sop & 22:30 & 30 & 101.5 & 3 & $\mathrm{~m}$ & 4 & 8 & 4 & 23 & 7 & 218 & $330 \bullet$ & 110 & 90 & 110 \\
\hline 4-Sep & 23:00 & 30 & 102.0 & 3 & $\mathrm{~m}$ & 4 & 6 & 4 & 22 & 6 & 14 & 197 & 28 & 8 & 14 \\
\hline 4.Sep & 23:30 & 30 & 102.5 & 3 & $\mathrm{~m}$ & 4 & 6 & 4 & 20 & 6 & 140 & $197 \mathrm{e}$ & 280 & 80 & 140 \\
\hline 5-Sep & $0: 00$ & 30 & 103.0 & 3 & $\mathrm{~m}$ & 4 & 7 & 3 & 20 & 6 & 16 & 74 & 110 & 18 & 14 \\
\hline 5-Sop & $0: 30$ & 30 & 103.5 & 3 & $\mathrm{~m}$ & 4 & 9 & 2 & 11 & 3 & 16 & $74 \theta$ & 1100 & 180 & $14 \circ$ \\
\hline 5-Sop & $1: 00$ & 30 & 104.0 & 3 & $\mathrm{~m}$ & 4 & 5 & 4 & 17 & 5 & 15 & 42 & 173 & 58 & 11 \\
\hline 5-Sop & $1: 30$ & 30 & 104.5 & 3 & $\mathrm{~m}$ & 4 & 6 & 2 & 17 & 4 & 150 & 420 & 173 & 580 & 110 \\
\hline 5-Sep & 2:00 & 30 & 105.0 & 3 & $\mathrm{~m}$ & 4 & 6 & 4 & 15 & 4 & $16 \mathrm{~m}$ & 24 & 185 & 123 & 11 \\
\hline 5-Sop & $2: 30$ & 30 & 105.5 & 31 & $\mathrm{~m}$ & 4 & 5 & 3 & 12 & 3 & 160 & $24^{\circ}$ & $185^{\circ}$ & 1230 & 110 \\
\hline 5-Sop & 3:00 & 30 & 106.0 & 3 & $m$ & 4 & 5 & 3 & 9 & 2 & $18 \mathrm{~m}$ & 19 & 138 & 146 & 8 \\
\hline 5--iop & $3: 30$ & 30 & 106.5 & 3 & $\mathrm{~m}$ & 4 & 6 & 3 & 5 & 1 & $18 \circ$ & 19. & 138 & $146 \circ$ & 80 \\
\hline 5-Sep & $4: 00$ & 30 & 107.0 & 31 & $\mathrm{~m}$ & 4 & 2 & 2 & 10 & 1 & $20 \mathrm{~m}$ & 13 & 67 & 116 & 7 \\
\hline 5-Sop & $4: 30$ & 30 & 107.5 & 3 & $\mathrm{~m}$ & 4 & 6 & 3 & 8 & 2 & $20 a$ & 130 & $677^{\circ}$ & 1160 & 70 \\
\hline 5-Sop & $5: 00$ & 30 & 108.0 & 3 & $\mathrm{~m}$ & 4 & 6 & 3 & 10 & 2 & $22 \mathrm{~m}$ & 13 & 41 & 80 & 9 \\
\hline 5-Sop & $5: 30$ & 30 & 108.5 & 2 & $\mathrm{~m}$ & 4 & 5 & 1 & 9 & 2 & 22 & 130 & 410 & 800 & 90 \\
\hline 5-Sop & $6: 00$ & 30 & ino? & 2 & $\mathrm{~m}$ & 4 & 4 & 2 & $B$ & 1 & $24 \mathrm{~m}$ & 10 & 27 & 50 & 10 \\
\hline 5-Sep & $6: 30$ & 30 & 109.5 & 2 & $\mathrm{~m}$ & 4 & 2 & 3 & 9 & 1 & 24. & 100 & 270 & $50 \theta$ & 100 \\
\hline 5-Sop & $7: 00$ & 30 & 110.0 & 2 & $\mathrm{~m}$ & 4 & 6 & 2 & 9 & 2 & $26 \mathrm{~m}$ & 8 & 16 & 34 & 18 \\
\hline 5-Sep & $7: 30$ & 30 & 110.5 & 21 & $\mathrm{~m}$ & 4 & 18 & 4 & $18 \mathrm{~m}$ & 9 & 260 & 80 & 160 & 340 & 180 \\
\hline 5-Sep & $8: 00$ & 30 & 111.0 & 2 & & 12 & 41 & 13 & $41 \mathrm{~m}$ & 22 & $28 \mathrm{~m}$ & 7 & 13 & 22 & 42 \\
\hline 5-Sop & $8: 30$ & 30 & 111.5 & 2 & & 15 & 61 & 20 & $61 \mathrm{~m}$ & 35 & 280 & 70 & 138 & $22 \theta$ & 420 \\
\hline 5-Sop & 9:00 & 30 & 112.0 & 11 & & 10 & 151 & 265 & $151 \mathrm{~m}$ & 188 & $30 \mathrm{~m}$ & 6 & 12 & 17 & 91 \\
\hline
\end{tabular}




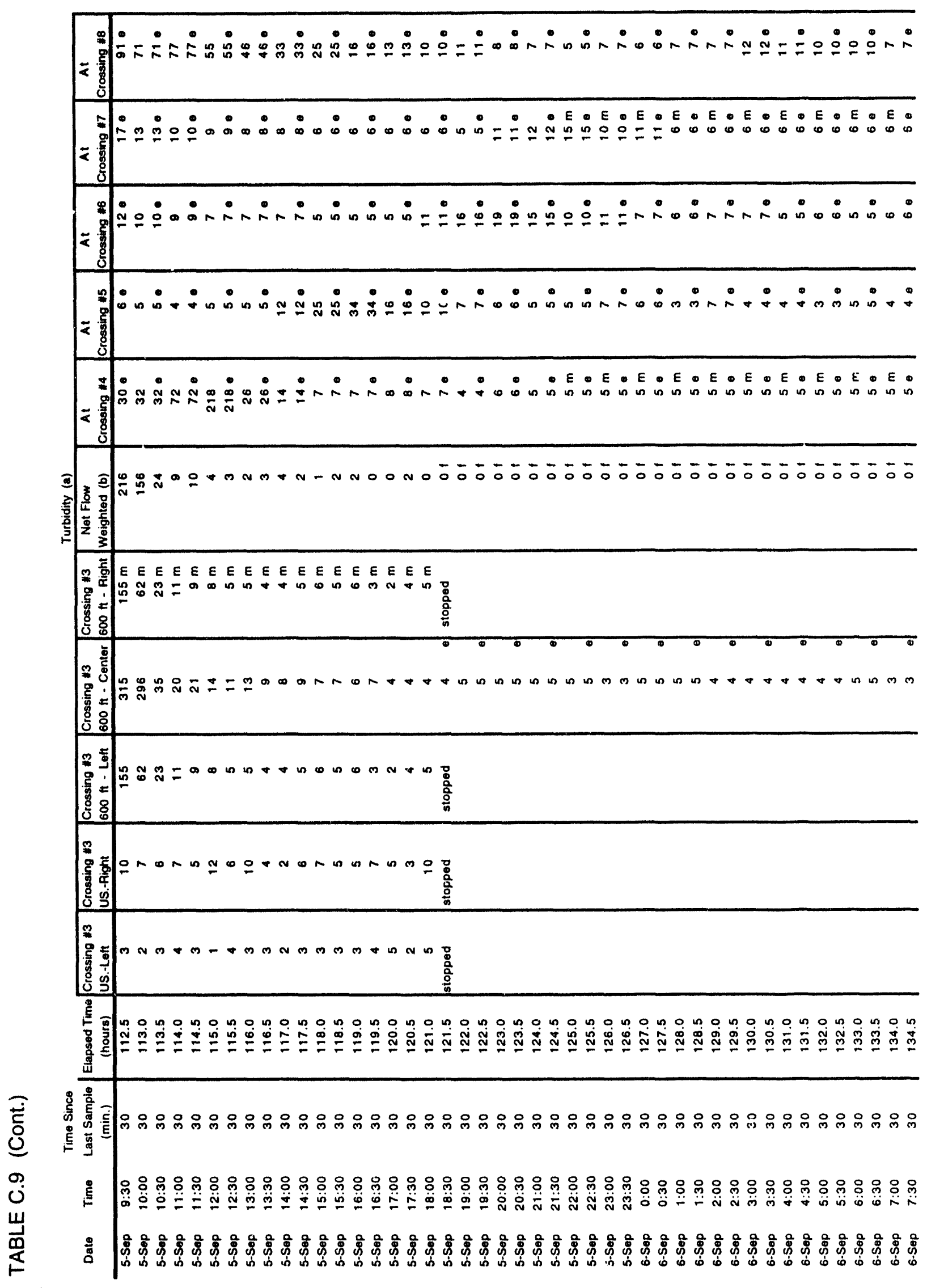


TABLE C.9 (Cont.)

\begin{tabular}{|c|c|c|c|c|c|c|c|c|c|c|c|c|c|c|}
\hline \multirow[b]{2}{*}{ Dato } & \multicolumn{3}{|c|}{ Time Since } & \multirow[b]{2}{*}{$\begin{array}{l}\text { Crossing } * 3 \\
\text { US.-Loft }\end{array}$} & \multirow[b]{2}{*}{$\begin{array}{l}\text { Crossing } 13 \\
\text { US. Right }\end{array}$} & \multicolumn{9}{|c|}{ Turbidity (a) } \\
\hline & Time & $\begin{array}{l}\text { Last Samplo } \\
\text { (min.) }\end{array}$ & $\begin{array}{c}\text { Elapsed Time } \\
\text { (hours) }\end{array}$ & & & $\begin{array}{l}\text { Crossing :3 } \\
600 \mathrm{tt} \text { - Loft }\end{array}$ & $\begin{array}{l}\text { Crossing } 13 \\
600 \mathrm{H} \text { - Conter }\end{array}$ & $\begin{array}{l}\text { Crossing *3 } \\
600 \mathrm{ft} \text { - Right }\end{array}$ & \begin{tabular}{|c|} 
Net Flow \\
Woighted (b)
\end{tabular} & $\begin{array}{c}\text { At } \\
\text { Crossing } 44\end{array}$ & $\begin{array}{c}\text { At } \\
\text { Croosing } 45\end{array}$ & $\begin{array}{c}\text { At } \\
\text { Crossing } * 6\end{array}$ & $\begin{array}{c}\text { At } \\
\text { Crossing } \# 7\end{array}$ & $\begin{array}{c}\text { At } \\
\text { Crossing } 18\end{array}$ \\
\hline 6-Sop & $8: 00$ & 30 & 135.0 & & & & 7 & & $0 f$ & $5 \mathrm{~m}$ & 4 & 5 & $6 \mathrm{~m}$ & 7 \\
\hline 6-Sop & $8: 30$ & 30 & 135.5 & & & & 7 & & 01 & 5. & 4. & $5 \bullet$ & $6 \bullet$ & 70 \\
\hline 6-Sop & 9:00 & 30 & 136.0 & & & & 4 & & 01 & $5 \mathrm{~m}$ & 5 & 5 & $6 \mathrm{~m}$ & 7 \\
\hline 6-Sop & $9: 30$ & 30 & 136.5 & & & & 4 & & of & 5. & 5. & $5 \bullet$ & 60 & 7. \\
\hline 6-Sep & $10: 00$ & 30 & 137.0 & & & & 6 & & 01 & $5 \mathrm{~m}$ & 4 & 8 & 6 & 5 \\
\hline 6-Sep & $10: 30$ & 30 & 137.5 & & & & 6 & & of & $5 \cdot$ & 40 & $8 \bullet$ & 60 & 5. \\
\hline 6-Sop & $11: 00$ & 30 & 138.0 & & & & 5 & & of & 4 & 1 & 4 & 5 & 4 \\
\hline 6-Sep & $11: 30$ & 30 & 138.5 & & & & $5 \mathrm{~m} / \mathrm{\theta}$ & & $0 t$ & 40 & $1 \bullet$ & $4 \cdot$ & $5 \cdot$ & 40 \\
\hline 6-Sop & $12: 00$ & 30 & 139.0 & & & & 4 & & of & 2 & 2 & 5 & 4 & 3 \\
\hline 6-Sep & $12: 30$ & 30 & 139.5 & & & & 4 & & of & 2 & 2 & 5. & 40 & 3 . \\
\hline 6-Sep & $13: 00$ & 30 & 140.0 & & & & 4 & & 01 & 3 & 2 & 5 & 4 & 4 \\
\hline 6-Sop & $13: 30$ & 30 & 140.5 & & & & 4 & & 01 & 30 & 2 & 50 & 40 & 40 \\
\hline 6-Sop & $14: 00$ & 30 & 141.0 & & & & 4 & & of & 3 & 1 & 7 & 5 & 3 \\
\hline 6-Sep & 14:30 & 30 & 141.5 & & & & 4 & & of & 3. & 1. & $7 \bullet$ & 50 & 3 . \\
\hline 6-Sep & $15: 00$ & 30 & 142.0 & & & & 1 & & 01 & 4 & 4 & 4 & 4 & 2 \\
\hline 6-Sop & $15: 30$ & 30 & 142.5 & & & & 1 & & of & 40 & 40 & $4 \cdot$ & 40 & 20 \\
\hline 6-Sop & $16: 0 C$ & 30 & 143.0 & & & & 1 & & of & 3 & 3 & 27 & 4 & 5 \\
\hline 6-Sep & $16: 30$ & 30 & 143.5 & & & & 1 & & 01 & $3 \bullet$ & 3. & 27 & 40 & 5. \\
\hline 6-Sep & $17: 00$ & 30 & 144.0 & & & & 3 & & 01 & 5 & 3 & 6 & 3 & 2 \\
\hline 6-Sep & $17: 30$ & 30 & 144.5 & & & & 3 & & 01 & 50 & 3 & 6. & 30 & 20 \\
\hline 6-Sop & $18: 00$ & 30 & 145.0 & & & & 3 & & 01 & 3 & 2 & 4 & 4 & 3 \\
\hline 6-Sep & $18: 30$ & 30 & 145.5 & & & & 3 & & of & 30 & 20 & 40 & 40 & 3. \\
\hline 6-Sep & 19:00 & 30 & 146.0 & & & & 3 & & $0:$ & 3 & 1 & 4 & 3 & 3 \\
\hline 6-Sop & $19: 30$ & 30 & 146.5 & & & & 3 & & of & 30 & 10 & 40 & 30 & 3. \\
\hline 6-Sop & $20: 00$ & 30 & 147.0 & & & & 3 & & 01 & 2 & 2 & 4 & 3 & 4 \\
\hline 6-Sep & $20: 30$ & 30 & 147.5 & & & & 3 & & of & 20 & 2 & 40 & 30 & 4. \\
\hline 6-Sep & $21: 00$ & 30 & 148.0 & & & & 3 & & of & 3 & 2 & 3 & 4 & 4 \\
\hline 6-Sep & $21: 30$ & 30 & 148.5 & & & & 3 & & of & 3. & 2 & 3. & 40 & 4. \\
\hline 6-Sep & 22:00 & 30 & $14 \overline{9} .0$ & & & & 2 & & of & 2 & 4 & 4 & 4 & 2 \\
\hline 6-Sep & 22:30 & 30 & 149.5 & & & & 2 & & of & 20 & 40 & 40 & 40 & 20 \\
\hline 6-Sop & 23:00 & 30 & 150.0 & & & & 3 & & 01 & 3 & 3 & 4 & 4 & 3 \\
\hline 6-Sep & $23: 30$ & 30 & 150.5 & & & & 3 & & of & $3 \bullet$ & 3. & 4. & 40 & 3 . \\
\hline 7-Sep & $0: 00$ & 30 & 151.0 & & & & 1 & & of & 7 & 3 & 18 & 4 & 3 \\
\hline 7-Sop & $0: 30$ & 30 & 151.5 & & & & 1 & & 01 & 70 & 3. & 18. & 40 & 30 \\
\hline 7-Sop & $1: 00$ & 30 & 152.0 & & & & 2 & & 01 & 6 & 4 & 4 & 3 & 2 \\
\hline 7-Sop & $1: 30$ & 30 & 152.5 & & & & 2 & & of & 60 & 40 & 40 & 30 & 20 \\
\hline 7-Sop & $2: 00$ & 30 & 153.0 & & & & 1 & & of & 5 & 3 & 10 & 2 & 5 \\
\hline 7-Sep & $2: 30$ & 30 & 153.5 & & & & 1 & & $0 t$ & 50 & 30 & 100 & 20 & $5 \circ$ \\
\hline 7-Sop & $3: 00$ & 30 & 154.0 & & & & 2 & & of & 2 & 5 & 8 & 5 & 3 \\
\hline 7-Sop & $3: 30$ & 30 & 154.5 & & & & 2 & & 01 & $2 \theta$ & 50 & 80 & 50 & $3 e$ \\
\hline 7-Sop & 4:00 & 30 & 155.0 & & & & 3 & & of & 3 & 4 & 4 & 4 & 3 \\
\hline 7-Sop & $4: 30$ & 30 & 155.5 & & & & 3 & & 01 & 3 & 40 & 40 & 40 & 30 \\
\hline 7-Sop & $5: 00$ & 30 & 156.0 & & & & 1 & & 01 & 3 & 3 & 4 & 3 & 2 \\
\hline 7-Sop & $5: 30$ & 30 & 156.5 & & & & 1 & & of & $3 e$ & 30 & 40 & $3 e$ & 20 \\
\hline 7-Sep & $6: 00$ & 30 & 157.0 & & & & 2 & & 01 & 3 & 4 & 13 & 4 & 3 \\
\hline
\end{tabular}


TABLE C.9 (Cont.)

\begin{tabular}{|c|c|c|c|c|c|c|c|c|c|c|c|c|c|c|}
\hline \multirow[b]{2}{*}{ Date } & \multicolumn{3}{|c|}{ Time Since } & \multicolumn{11}{|c|}{ Turbidity (a) } \\
\hline & Time & $\begin{array}{c}\text { Last Sample } \\
\text { (min.) }\end{array}$ & $\begin{array}{c}\text { Elapsed Time } \\
\text { (hours) }\end{array}$ & $\begin{array}{l}\text { Crossing } * 3 \\
\text { US.-Left }\end{array}$ & \begin{tabular}{|l|} 
Crossing $* 3$ \\
US.-Aight
\end{tabular} & $\begin{array}{l}\text { Crossing } 43 \\
600 \mathrm{ft} \text { - Left }\end{array}$ & $\begin{array}{l}\text { Crossing } * 3 \\
600 \mathrm{Ht} \text { - Conter }\end{array}$ & $\begin{array}{l}\text { Crossing \#3 } \\
600 \mathrm{H} \text { - Right }\end{array}$ & \begin{tabular}{|c|} 
Net Flow \\
Weighted (b)
\end{tabular} & $\begin{array}{c}\text { At } \\
\text { Crossing *4 }\end{array}$ & $\begin{array}{c}\text { At } \\
\text { Crossing } 45\end{array}$ & $\begin{array}{c}\text { At } \\
\text { Crosaing } 46\end{array}$ & $\begin{array}{c}\text { At } \\
\text { Crossing } \# 7\end{array}$ & $\begin{array}{c}\text { At } \\
\text { Crossing } 18\end{array}$ \\
\hline 7-Sop & $6: 30$ & 30 & 157.5 & & & & 2 & • & 01 & $3 \cdot$ & $40^{\circ}$ & $13 \bullet$ & 40 & 30 \\
\hline 7-Sep & 7:00 & 30 & 158.0 & & & & 3 & & of & 2 & 4 & 3 & 4 & 2 \\
\hline 7-Sep & $7: 30$ & 30 & 158.5 & & & & 3 & . & 01 & $2 \bullet$ & 40 & 3. & 40 & 20 \\
\hline 7-Sep & $8: 00$ & 30 & 159.0 & & & & 4 & & 01 & 3 & 3 & 2 & 5 & 4 \\
\hline 7-Sop & $8: 30$ & 30 & 159.5 & & & & 4 & $\theta$ & of & 30 & 30 & 2 & 5. & $\therefore$ \\
\hline 7-Sep & 9:00 & 30 & 160.0 & & & & 3 & & of & 3 & 5 & 9 & 6 & 4 \\
\hline 7-Sep & $9: 30$ & 30 & 160.5 & & & & 3 & 0 & of & 30 & 5. & 9. & 6. & 40 \\
\hline 7-Sop & $10: 00$ & 30 & 161.0 & & & & 3 & & of & 5 & 4 & 2 & 5 & 12 \\
\hline 7-Sep & $10: 30$ & 30 & 161.5 & & & & 3 & o & 01 & 50 & 40 & 20 & 50 & $12 \circ$ \\
\hline 7-Sop & $11: 00$ & 30 & 162.0 & & & & 3 & & 01 & 6 & 4 & 2 & 3 & 6 \\
\hline 7-Sep & $11: 30$ & 30 & 162.5 & & & & 3 & ๑) & 01 & $6 \mathrm{e}$ & 40 & 2 & 3. & 6. \\
\hline 7.Sep & $12: 00$ & 30 & 163.0 & & & & 7 & & 01 & 5 & 3 & 7 & 5 & 6 \\
\hline 7-Sop & $12: 30$ & 30 & 163.5 & & & & 7 & . & 01 & 5. & 3. & $7 \bullet$ & 5. & 6. \\
\hline 7-SeD & 13:00 & 30 & 164.0 & & & & 3 & & 01 & 3 & 6 & 3 & 5 & 4 \\
\hline 7-Sep & $13: 30$ & 30 & 164.5 & & & & 3 & -) & 01 & 3. & 60 & 3. & 50 & 40 \\
\hline 7-Sep & $14: 00$ & 30 & 165.0 & & & & 4 & & 01 & 3 & 5 & 3 & 7 & 8 \\
\hline 7-Sop & $14: 30$ & 30 & 165.5 & & & & 4 & ol & 01 & 30 & 5. & 3. & 70 & 8. \\
\hline 7.Sep & 15:00 & 30 & 166.0 & & & & 3 & & of & 4 & 2 & 4 & 8 & 10 \\
\hline 7-Sep & $15: 30$ & 30 & 166.5 & & & & 3 & e) & of & 40 & 2 & 40 & 80 & $10 \mathrm{e}$ \\
\hline 7-Sep & $16: 00$ & 30 & 167.0 & & & & 5 & & 01 & 5 & 2 & 4 & 9 & 7 \\
\hline 7-Sop & $16: 30$ & 30 & 167.5 & & & & 5 & e) & 01 & 5. & 20 & 40 & $9 \bullet$ & 7. \\
\hline 7-Sep & $17: 00$ & 30 & 168.0 & & & & 4 & & 01 & 3 & 2 & 3 & 5 & 2 \\
\hline 7-Sop & $17: 30$ & 30 & 168.5 & & & & 4 & 8 & of & 3 & 20 & 3 & 50 & 20 \\
\hline 7-Sep & 18:00 & 30 & 169.0 & & & & 4 & & 01 & 3 & 2 & 3 & 5 & 2 \\
\hline 7-Sep & $18: 30$ & 30 & 169.5 & & & & 4 & $\theta$ & of & 3. & 2. & 3. & 5. & 20 \\
\hline 7-Sep & $19: 00$ & 30 & 170.0 & & & & 3 & & 01 & 4 & 6 & 3 & 8 & 2 \\
\hline 7-Sep & $19: 30$ & 30 & 170.5 & & & & 3 & 0 & of & 40 & 60 & 30 & 80 & 20 \\
\hline 7-Sop & $20: 00$ & 30 & 171.0 & & & & 3 & & $0 t$ & 3 & 4 & 3 & 4 & 2 \\
\hline 7-Sop & $20: 30$ & 30 & 171.5 & & & & 3 & e) & of & 30 & 40 & 30 & 40 & 20 \\
\hline 7-Sep & $21: 00$ & 30 & 172.0 & & & & 3 & & $0 \mathrm{f}$ & 4 & 6 & 3 & 4 & 3 \\
\hline 7-Sep & 21:30 & 30 & 172.5 & & & & 3 & e) & of & 40 & 60 & 30 & 40 & 30 \\
\hline 7-Sep & 22:00 & 30 & 173.0 & & & & 2 & & of & 5 & 5 & 3 & 4 & 3 \\
\hline 7-Sep & 22:30 & 30 & 173.5 & & & & 2 & 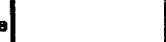 & 01 & 50 & 50 & 30 & $4 e$ & 30 \\
\hline 7-Sep & 23:00 & 30 & 174.0 & & & & 2 & & of & 4 & 5 & 3 & 5 & 2 \\
\hline 7.Sep & 23:30 & 30 & 174.5 & & & & 2 & . & of & 40 & 50 & 30 & 50 & 20 \\
\hline 8-Sep & $0: 00$ & 30 & 175.0 & & & & 4 & & $0 f$ & 5 & 6 & 3 & 6 & 3 \\
\hline 8-Sep & $0: 30$ & 30 & 175.5 & & & & 4 & a) & 01 & $5 \theta$ & 60 & 30 & 60 & 30 \\
\hline B-Sep & $1: 00$ & 30 & 176.0 & & & & 3 & & $0 f$ & 4 & 15 & 4 & 5 & 3 \\
\hline 8-Sep & $1: 30$ & 30 & 176.5 & & & & 3 & a & 01 & 40 & 150 & 40 & 50 & $3 e$ \\
\hline 8-Sep & $2: 00$ & 30 & 177.0 & & & & 3 & & of & 4 & 9 & 3 & 6 & 2 \\
\hline 8-Sep & $2: 30$ & 30 & 177.5 & & & & 3 & o. & of & 40 & 90 & 3. & 60 & 20 \\
\hline B.Sep & $3: 00$ & 30 & 178.0 & & & & 4 & & $0 f$ & 4 & 6 & 3 & 4 & 3 \\
\hline 8-Sep & $3: 30$ & 30 & 178.5 & & & & 4 & 8 & of & 40 & 60 & 30 & 40 & 3 。 \\
\hline 8-Sep & $4: 00$ & 30 & 179.0 & & & & 3 & & 01 & 5 & 6 & 3 & 5 & 3 \\
\hline 8-Sep & $4: 30$ & 30 & 179.5 & & & & 3 & el & of & 50 & $6 \mathrm{e}$ & 30 & 5 e & 30 \\
\hline
\end{tabular}


TABLE C.9 (Cont.)

\begin{tabular}{|c|c|c|c|c|c|c|c|c|c|c|c|c|c|c|}
\hline \multirow[b]{2}{*}{ Date } & \multirow[b]{2}{*}{ Time } & \multicolumn{2}{|l|}{ Time Since } & \multicolumn{11}{|c|}{ Turbidity (a) } \\
\hline & & $\begin{array}{l}\text { Last Sample } \\
\text { (min.) }\end{array}$ & $\begin{array}{c}\text { Elapsed Timo } \\
\text { (hours) }\end{array}$ & $\begin{array}{l}\text { Crossing *3 } \\
\text { US. Left }\end{array}$ & $\begin{array}{l}\text { Crossing *3 } \\
\text { US.-Plight }\end{array}$ & $\begin{array}{l}\text { Crossing *3 } \\
600 \mathrm{th} \text { - Left }\end{array}$ & $\begin{array}{l}\text { Crossing *3 } \\
600 \mathrm{t} \text { - Center }\end{array}$ & \begin{tabular}{|l|} 
Crossing \#3 \\
600 H - Right
\end{tabular} & \begin{tabular}{|c} 
Not Flow \\
Woightod (b)
\end{tabular} & $\begin{array}{c}\text { At } \\
\text { Crossing } 14\end{array}$ & $\begin{array}{c}\text { At } \\
\text { Crossing }\end{array}$ & $\begin{array}{c}\text { At } \\
\text { Crossing }: 6\end{array}$ & $\begin{array}{c}\text { At } \\
\text { Crossing } \because 7\end{array}$ & $\begin{array}{c}\text { At } \\
\text { Crossing } \approx 8\end{array}$ \\
\hline 8-Sep & $5: 00$ & 30 & 180.0 & & & & 5 & & 01 & 2 & 7 & 4 & 4 & 4 \\
\hline 8-Sop & $5: 30$ & 30 & 180.5 & & & & 5 & & 01 & $\begin{array}{l}2 \bullet \\
3\end{array}$ & $7 \bullet$ & 40 & $\begin{array}{l}40 \\
3\end{array}$ & 3 \\
\hline 8-Sop & $6: 00$ & 30 & 181.0 & & & & 3 & & 01 & 3 & 7. & 3. & 3. & 3. \\
\hline 8-Sop & $6: 30$ & 30 & 181.5 & & & & 3 & & of & $\begin{array}{l}3 \bullet \\
3\end{array}$ & 5 & 3 & 3 & 4 \\
\hline 8-Sop & $7: 00$ & 30 & 182.0 & & & & 5 & & 01 & 3 & 5. & 3. & 3. & 40 \\
\hline 8-Sop & $7: 30$ & 30 & 182.5 & & & & 5 & & $\begin{array}{ll}0 & 1 \\
0 & 1\end{array}$ & $\begin{array}{l}3 \bullet \\
5\end{array}$ & 5 & 3 & 3 & 3 \\
\hline 8-Sop & $8: 00$ & 30 & 183.0 & & & & $\begin{array}{l}3 \\
3\end{array}$ & & $\begin{array}{ll}0 \\
0\end{array}$ & 5 & 5. & 3. & 3 . & 3 . \\
\hline 8-Sop & 8:30 & 30 & 183.5 & & & & 26 & & 01 & 4 & 4 & 2 & 3 & \\
\hline $\begin{array}{l}\text { 8-Sop } \\
\text { 8-Sep }\end{array}$ & $\begin{array}{l}9: 00 \\
9: 30\end{array}$ & $\begin{array}{l}30 \\
30\end{array}$ & $\begin{array}{l}184.0 \\
184.5\end{array}$ & & & & 26 & & 01 & 40 & 4. & 2 • & 30 & - \\
\hline & & & & & & & & & & & & & & \\
\hline
\end{tabular}

(a) $\mathrm{m}$ = sample missed / value extrapolated

- = measurements from previous samples are extrapolated for graphing purposes only

$t=$ after the upstream sampler is removed, the NET flow weightod turbidity is assumed to be zero

(for the pUripos of calculat turbidity only)

(b) $c$ = flow woightod value taken simply as the conter sampler valus less the background (if availabie).

Total Net Downatream Flow-Wolghted NTU'hours = 12716 
Appendix D:

Dissolved Oxygen and Temperature Measurements 
TABLE D.1 Dissolved Oxygen and Temperature Measurements

\begin{tabular}{|c|c|c|c|c|c|c|c|}
\hline Date & Crossing & Time & $\begin{array}{c}\text { Elapsed Time } \\
\text { (hours) }\end{array}$ & $\begin{array}{c}\text { DO } \\
\text { Upstream } \\
(\mathrm{ug} / \mathrm{l}) \\
\end{array}$ & $\begin{array}{c}\text { DO } \\
\text { Downstream } \\
(u g / l)\end{array}$ & $\begin{array}{c}\text { Temperature } \\
\text { Upstream } \\
\text { (C) }\end{array}$ & $\begin{array}{c}\text { Temperature } \\
\text { Downstream } \\
\text { (C) }\end{array}$ \\
\hline 14-Aug & 4 & $0: 30$ & 0.0 & 8.4 & 8.4 & a & $a$ \\
\hline 14-Aug & 4 & $5: 00$ & 4.5 & 8.7 & 8.7 & $a$ & $a$ \\
\hline 14-Aug & 4 & $9: 00$ & 8.5 & 8.8 & 8.8 & a & $a$ \\
\hline 14-Aug & 4 & $12: 00$ & 11.5 & 10.1 & 10.1 & $a$ & $a$ \\
\hline 14-Aug & 4 & 21:00 & 20.5 & 8.5 & 8.5 & a & a \\
\hline 15-Aug & 4 & 9:00 & 22.5 & 10.1 & 10.1 & a & a \\
\hline & 2 & (x) & 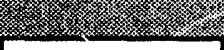 & 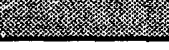 & 28 & (2) & 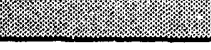 \\
\hline 19-Aug & 5 & 2:00 & 0 & 7.3 & 8.1 & 16.9 & 17.1 \\
\hline 19-Aug & 5 & 6:00 & 4.0 & 7.1 & 8.2 & 15.5 & 15.6 \\
\hline 19-Aug & 5 & $10: 00$ & 8.0 & 9.4 & 9.1 & 17.1 & 17.6 \\
\hline 19-Aug & 5 & $14: 00$ & 12.0 & 10.1 & 10.5 & 21.1 & 22.2 \\
\hline 19-Aug & 5 & $18: 30$ & 16.5 & 9.5 & 10.2 & 22.3 & 24.8 \\
\hline . & 2 & 2 & 20 & (2) & 2 & (2) & 2 \\
\hline 22-Aug & 7 & $2: 00$ & 0 & 7.8 & 7.1 & 16.8 & 16.5 \\
\hline 22-Aug & 7 & $6: 00$ & 4.0 & 8.1 & 7 & 14.9 & 14.7 \\
\hline 22-Aug & 7 & $10: 00$ & 12.0 & 7.9 & 7.1 & 15.6 & 16.7 \\
\hline 22-Aus & 7 & $14: 00$ & 16.5 & 7 & 8.7 & 17.5 & 17.5 \\
\hline 20 & 2 & 2 & 小ম & it & 8 & 2:-2: & (2) \\
\hline 26-Aug & 2 & $14: 00$ & 0 & 9.4 & 9.6 & 14.2 & 14.2 \\
\hline 26-Aug & 2 & $18: 00$ & 4.0 & 8.1 & 9.4 & 16.2 & 16.2 \\
\hline 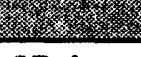 & & 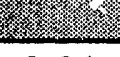 & 2 & 2 & 2 & 3.2 & 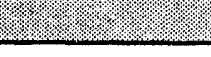 \\
\hline 27-Aug & 1 & $9: 34$ & 0 & 10.2 & - & 10.7 & - \\
\hline 27-Aug & 1 & $14: 30$ & 5 & 9.3 & - & 16.2 & - \\
\hline 28-Aug & 1 & $9: 42$ & 24 & 10.3 & - & 11.5 & - \\
\hline 28-Aug & 1 & $14: 22$ & 29 & 9.1 & - & 15.3 & - \\
\hline 28-Aug & 1 & $18: 30$ & 33 & 9.4 & - & 15.8 & - \\
\hline 29-Aug & 1 & $9: 55$ & 48 & 10.8 & - & 9.4 & - \\
\hline 29-Aug & 1 & $13: 00$ & 51 & 9.7 & - & 13.8 & - \\
\hline
\end{tabular}


TABLE D.1 (Cont.)

\begin{tabular}{|c|c|c|c|c|c|c|c|}
\hline Date & Crossing & Time & $\begin{array}{c}\text { Elapsed Time } \\
\text { (hours) }\end{array}$ & $\begin{array}{c}\text { DO } \\
\text { Upstream } \\
(\mathrm{ug} / \mathrm{l})\end{array}$ & $\begin{array}{c}\text { DO } \\
\text { Downstream } \\
(\mathrm{ug} / \mathrm{l})\end{array}$ & $\begin{array}{c}\text { Temperature } \\
\text { Upstream } \\
\text { (C) }\end{array}$ & $\begin{array}{c}\text { Temperature } \\
\text { Downstream } \\
\text { (C) }\end{array}$ \\
\hline 27-Aug & 1 & $10: 40$ & 0 & - & 10.1 & - & 11.9 \\
\hline 27-Aug & 1 & $13: 45$ & 3 & - & 9.9 & - & 15.1 \\
\hline 28-Aug & 1 & $10: 25$ & 24 & - & 10.1 & - & 11.4 \\
\hline 28-Aug & 1 & $14: 05$ & 27 & - & 10.2 & - & 14.5 \\
\hline 28-Aug & 1 & 19:16 & 33 & - & 9.2 & - & 14.5 \\
\hline 29-Aug & 1 & $9: 15$ & 47 & - & 10.0 & - & 8.1 \\
\hline 29-Aug & 1 & $13: 50$ & 51 & - & 10.0 & - & 14.7 \\
\hline 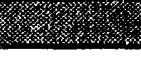 & 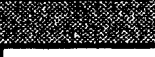 & 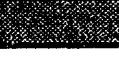 & 8 & S- & 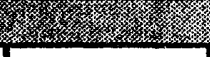 & 8 & 2 \\
\hline 31-Aug & 3 & 13:05 & 0 & 9.7 & - & 17.1 & - \\
\hline 31-Aug & 3 & $17: 44$ & 4.6 & 7.7 & - & 16.9 & - \\
\hline 31-Aug & 3 & $18: 42$ & 5.6 & 9 & - & 16.1 & - \\
\hline 1-Sep & 3 & $8: 35$ & 19.5 & 8.7 & - & 11.7 & - \\
\hline 1-Sep & 3 & $15: 20$ & 26.3 & 8.9 & - & 17.8 & - \\
\hline 2-Sep & 3 & $15: 45$ & 50.7 & 8.8 & - & 18.5 & - \\
\hline 3-Sep & 3 & $9: 06$ & 68.0 & 9.5 & - & 11.7 & - \\
\hline 3-Sep & 3 & $14: 00$ & 72.9 & 8.9 & - & 16.5 & - \\
\hline & & & & & & & \\
\hline 31-Aug & 3 & $14: 05$ & 0.0 & - & 9.2 & - & 15.4 \\
\hline 31-Aug & 3 & $16: 54$ & 2.8 & - & 9.4 & - & 17.5 \\
\hline 31-Aug & 3 & $19: 05$ & 5.0 & - & 8.3 & - & 15.9 \\
\hline 1-Sep & 3 & $9: 35$ & 19.5 & - & 9.5 & - & 12.4 \\
\hline 1-Sep & 3 & $14: 44$ & 24.7 & - & 9.5 & - & 17.1 \\
\hline 2-Sep & 3 & $15: 00$ & 48.9 & $=$ & 9.3 & - & 17.1 \\
\hline 3-Sep & 3 & $9: 38$ & 67.5 & - & 9.7 & - & 11.7 \\
\hline 3-Sep & 3 & $13: 19$ & 71.2 & - & 9.7 & - & 15.1 \\
\hline
\end{tabular}

$a=$ equipment malfunction, no temperature readings were measured. 

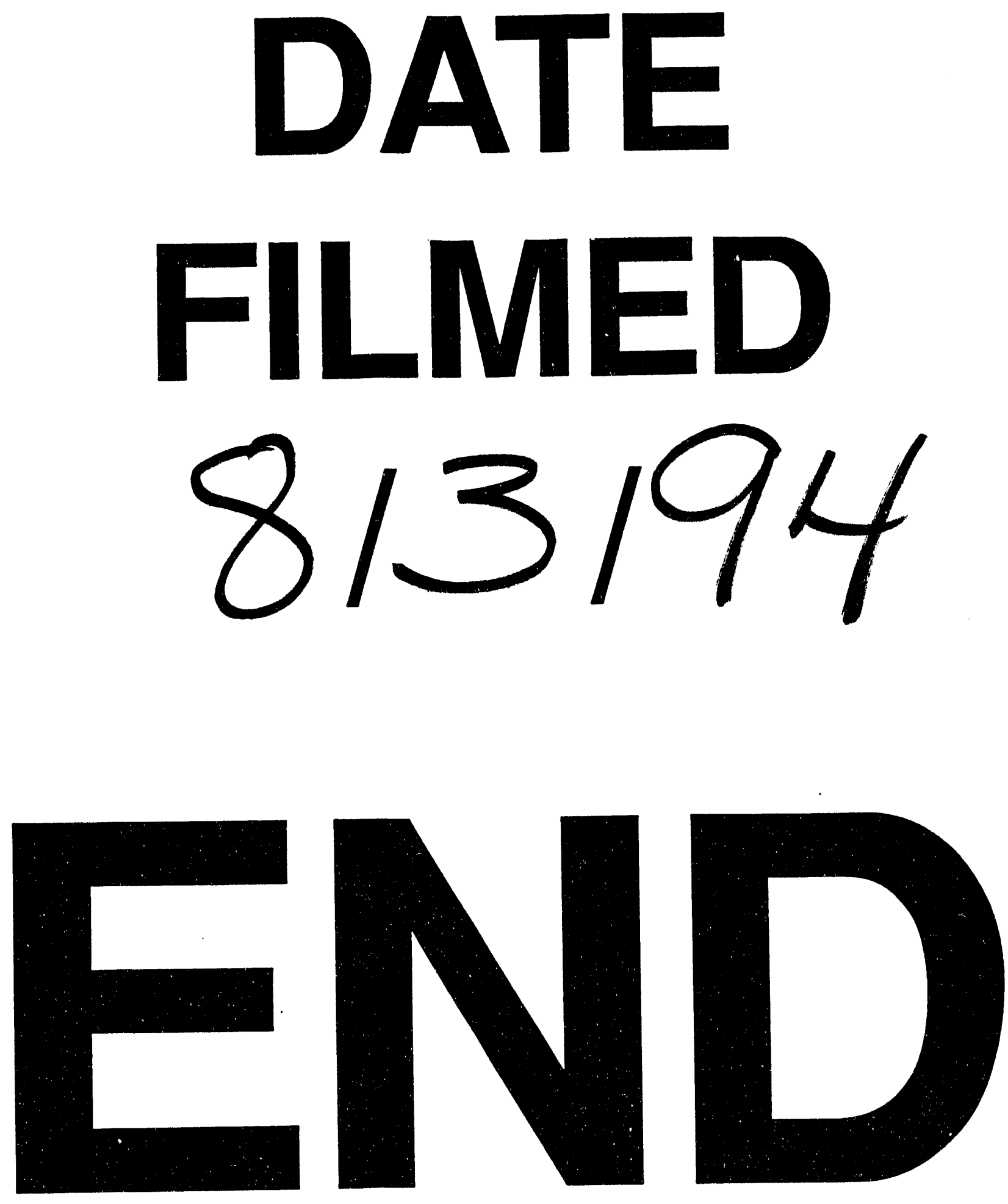
